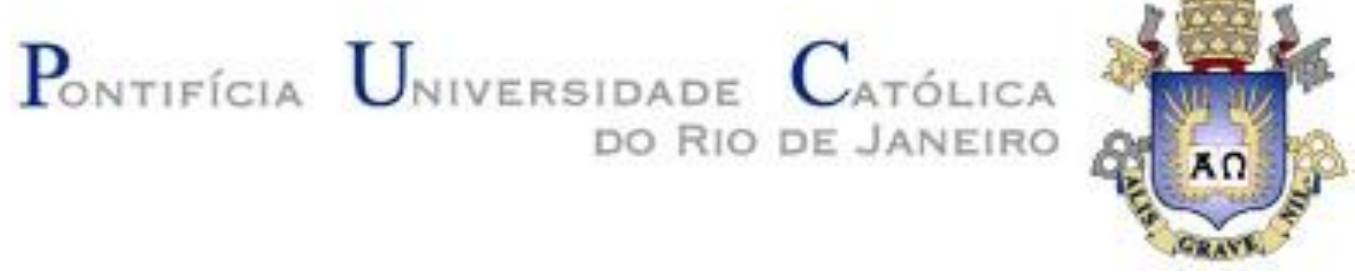

Uriel Massalves de Souza do Nascimento

\title{
Começar pelo fim: percorrendo a formação para e pelo negativo na Fenomenologia de Hegel \\ Tese de doutorado
}

Tese apresentada como requisito parcial para a obtenção do grau de Doutor em Filosofia pelo Programa de Pós-Graduação em Filosofia do Departamento de Filosofia do Centro de Teologia e Ciências Humanas da PUC-Rio.

Orientador: Prof. Pedro Duarte de Andrade

Rio de Janeiro, Dezembro de 2021 


\title{
Pontifícia Universidade C $_{\text {atólica }}$ DO RIO DE JANEIRO
}

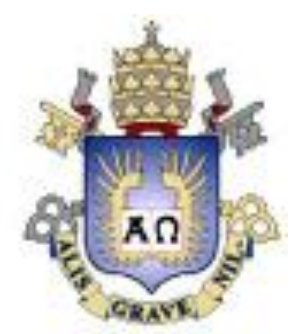

\section{Uriel Massalves de Souza do Nascimento}

\section{Começar pelo fim: percorrendo a formação para e pelo negativo na Fenomenologia de Hegel}

Tese apresentada como requisito parcial para a obtenção do grau de Doutor em Filosofia pelo Programa de Pós-Graduação em Filosofia do Departamento de Filosofia do Centro de Teologia e Ciências Humanas da PUC-Rio. Aprovada pela Comissão Examinadora abaixo assinada.

\author{
Prof. Pedro Duarte de Andrade \\ Orientador \\ Departamento de Filosofia - PUC-Rio
}

Prof. a Marloren Miranda Universidade de São Paulo - FFLCH/USP

Prof. Fabiano Lemos Universidade do Estado do Rio de Janeiro - PPGF/UERJ

Prof. ${ }^{\text {a }}$ Mirian Kussumi Universidade Federal Fluminense - PPGF/UFF

Prof. a Andrea Bieri Universidade Federal do Estado do Rio de Janeiro - DEFIL/ UNIRIO Rio de Janeiro, 13 de dezembro de 2021 
Todos os direitos reservados. É proibida a reprodução total ou parcial do trabalho sem autorização da universidade, do autor e da orientadora.

\section{Uriel Massalves de Souza do Nascimento}

Psicanalista. Graduado em filosofia pela UNIRIO. Mestre em filosofia pela PUC-RIO, com dissertação sobre antropofagia. Psicanalista filiado ao PUD - Psicanalistas Unidos pela Democracia e, também, ao Psi Maré - coletivo para atendimento de pessoas em situações de vulnerabilidade oriundas da Maré.

Ficha Catalográfica

Nascimento, Uriel Massalves de Souza do

Começar pelo fim : percorrendo a formação para e pelo negativo na fenomenologia de Hegel / Uriel Massalves de Souza do Nascimento ; orientador: Pedro Duarte de Andrade. - 2021.

204 f. ; $30 \mathrm{~cm}$

Tese (doutorado)-Pontifícia Universidade Católica do Rio de Janeiro, Departamento de Filosofia, 2021.

Inclui bibliografia

1. Filosofia - Teses. 2. Hegel. 3. Dialética. 4. Negativo. 5. Formação. I. Andrade, Pedro Duarte de. II. Pontifícia Universidade Católica do Rio de Janeiro. Departamento de Filosofia. III. Título. 
"Dedico essa tese aos meus pais

João Luiz do Nascimento e

Zoneide Massalves de Souza do Nascimento.

O carinho do lar foi a minha primeira formação

e aquela que me deu

e dá

afeto \& linguagem.

Se pensar é agradecer

Agradecer pode também ser pensar." 


\section{Agradecimentos}

Denken ist danken (pensar é agradecer). Esse modo de pensar pietista, que se encontra muitas vezes na obra de Heidegger, coloca o pensamento como uma forma de gratidão não edulcorada, muito diferente dessa que vemos circular, constantemente, nos dias de hoje. Coloca o agradecimento no plano mesmo de uma coragem e o pensamento com ela. Se tudo é gratuito e a vida é espontaneidade inexplicável, pensar é uma das formas de agradecer algo que é imerecido, posto não ser julgável por mérito. Além disso, em uma tese sobre formação, resta impossível, na seção dos agradecimentos, não agradecer a todos que consigo me lembrar que dela fizeram parte.

Começo agradecendo à minha mãe, Zoneide Massalves de Souza do Nascimento. Incontáveis memórias me ocorrem quando penso no sem número de vezes que ela me estimulou à leitura e à intelectualidade. A culminância na minha formação em filosofia, minha autorização como psicanalista e minha montagem de pequenas coreografias de dança de salão não puderam ser por ela vistas, mas guardam, em si, o carinho, o estímulo e o cuidado que foram o impulso inicial para que eu me tornasse o que, gradualmente, me torno. O bom humor, a língua ágil, e as tiradas rápidas que alguns observam em mim servem como marca genética de um estilo que soube fazer piada até com sua grave doença e sentindo dores imensas numa cama de hospital. Levo comigo, como levo a disposição e o cuidado com aqueles ao redor.

Depois, mas somente porque escrever por cima impede a leitura, ao meu pai, João Luiz do Nascimento. Com ele aprendi a importância da flexibilidade na posição do homem e, também, a importância de ter um espectro amplo de emoções: da fragilidade e da inocência até a capacidade agressiva para se defender. Aprendi, então, que a unilateralidade é quase sempre um embotamento subjetivo, o sujeito ficando cada vez mais amuado e mais agressivo quanto mais impotente se sente. Se as discussões contemporâneas sobre tarefas domésticas, papel masculino numa relação heterossexual, etc. me chocam mais pela distância das posições dos homens em 
relação ao que aprendi em casa, é graças ao que aprendi vendo meu pai tanto fazer, quanto dizer.

Em seguida, minha primeira orientadora, professora Diana Pinto. Foi com ela que dei os primeiros passos acadêmicos e aprendi o trabalho que dá ser um acadêmico, a seriedade de uma pesquisa com seres humanos e as dificuldades inerentes à universidade. Aprendi, também, - ou talvez tenha reforçado - que o bom humor forma muitos laços, a distância acadêmica não impedindo um contato genuíno. Trocando em miúdos: Diana não olha ninguém de cima porque é intelectual e doutora. Parece o básico, mas por vezes faz falta.

Agradeço ao Francisco Farias, meu atual supervisor e primeiro contato formador que tive, ainda a graduação, com a psicanálise. Se hoje exerço o mesmo ofício, foi e é em parte é porque tanto outrora como agora encontrei e encontro espaço para meus questionamentos da instituição psicanálise. Foi também o primeiro psicanalista que vi que não parece precisar manter uma pose e não rir e/ou debochar.

Agradeço ao Pedro Rocha, meu orientador de TCC e primeiro contato com a doença hegeliana da qual não vou me curar tão cedo. Foi, também, meu parceiro de sparring junto com Hércules Ferreira, abaixo mencionado. Um adorniano ir para o sparring mostra que ainda existe alguma salvação para além do intelecto.

Meus sinceros agradecimentos ao meu orientador por quase 7 anos, Pedro Duarte de Andrade. Desde a graduação na UNIRIO Pedro tentou apresentar o pensamento como uma aventura e, como orientador, sempre me permitiu explorar os caminhos que me interessavam, balizando aqui e ali quando a coisa ameaçava sair do eixo.

Agradeço também ao meu mestre na Dança de Salão, Carlinhos de Niterói, pelo cuidado, carinho e paciência no ensino, sempre se esforçando para que a profissão de professor e as aulas não se tornem uma repetição mecânica, mas propriamente arte.

Agradeço também aos professores Eduardo Cruz e Charles Feitosa, pelos contatos com Hegel, no caso do segundo, e pela possibilidade de dar uma aula inteirinha de Hegel durante a graduação, no caso do primeiro. 
Agradeço à professora Andrea Bieiri pelas milhares de aulas sobre Foucault, as conversas sobre filosofia francesa contemporânea, pela acolhida no estágio docente e pelo carinho com o qual sempre acolhia as dúvidas e as questões. Agradeço também pelo convite por IC, que até não esqueci, porque me confirmou a importância do tema e minha capacidade de expô-lo no meu primeiro momento de exposição pública aos alunos de filosofia.

Agradeço à professora Luisa Severo Buarque de Holanda pelas conversas, pelas aulas de Platão (que acabaram por me ajudar a diferir bem a dialética dele da de moderna) e pelos almoços conversando sobre coisas muito variadas, de intelectualidades e teses a coisas comezinhas. Infelizmente a pandemia ainda não permite tanto, mas em breve marcaremos nosso forró.

Agradeço ao professor Fabiano Lemos por acompanhar esse trabalho desde sua gestação até agora, em seu derradeiro momento. Suas observações argutas e sensíveis me ajudaram a delinear coisas que não me pareciam claras e esse trabalho. Agradeço também pelo insight que inverte uma forma muito típica de pensar a relação de Heidegger com o nazismo, o que me foi muito útil em aula.

Agradeço à Marloren Miranda primeiro pelo encontro, depois pelas conversas rápidas de Facebook, uma das quais me fez nota que eu já estava em/com uma tese, só não havia me dado conta. Não fosse aquela conversa, talvez ficasse rodando ainda mais em busca de algo que eu já tinha.

Agradeço à Mirian Monteiro Kussumi (ou pequena Eva, porque ela adora a banda) por nossa amizade ser próxima e presente a ponto de estarmos nos apoiando mutuamente sempre que o outro precisa. Não é possível não mencionar o cuidado recebido quando da morte da minha mãe, com as ligações, as mensagens e todo o carinho de alguém que fez questão de demonstrar constantemente que estava ali.

Agradeço a Felipe Ramos Gall, pelas piadas, humor, apoio e por ser sempre um amigo com o qual se pode contar, inclusive em situações pesadas como a perda de alguém tão próximo.

Agradeço a Carlos Eduardo da Rocha pelas trocas, perguntas, apoio e por me mostrar uma certa inquietação curiosa com a filosofia que é rara de se ver. As questões sempre estimulam qualquer professor digno da função a pensar e as suas, 
nesse sentido, têm sido ótimas. Somado à gentileza e ao cuidado próprios à amizade, se tornam uma receita para uma boa companhia.

Agradeço à Maria Cintra pelo apoio, deboche, dicas, conversas e companhia, mas sobretudo pela nossa interação ser forte o suficiente para que a gente tenha bem pouco limite e bastante pouca noção e, ao mesmo tempo, bastante carinho e cuidado um pelo outro. É uma alternância quase dialética, afinal.

Agradeço à Carmel Ramos pela presença constante, pelo cuidado trocado inclusive em formas de lembrancinha quando em viagem e pelas conversas absolutamente aleatórias, que vão de metafilosofia ao porquê do indie ter que acabar.

Agradeço ao Ivan Osório pela amizade de mais ou menos quinze anos nos quais sempre tivemos uma das interações mais discordantes e ao mesmo tempo mais afinadas que eu consigo ter. Apesar de não concordarmos em praticamente nada, nas poucas coisas que concordamos creio que temos a dimensão mais fundamental da amizade, sendo esse o segredo do sucesso.

Agradeço ao Hercules Xavier Ferreira pelos ensinamentos no Muay Thai, pelos deboches, zoeiras e outros quetais, mas também pela seriedade com a qual acolhe momentos de dificuldade ou questões sérias. Em breve, voltaremos aos treinos. Rush!

I thank Tatiana Nebusova or rather Taniushka for our flirtationship (or should we call it teasingship?) and for the many moments of a very fun and deep interaction despite the distance.

Agradeço à Deysielle Chagas pelas conversas engraçada e aleatórias, umas ainda mais do que as outras, sobre tudo e sobre nada ao mesmo tempo. Agradeço também por compartilhar a experiência, um tanto similar à minha, de ser de classe emergente fazendo mestrado e doutorado. Esses pequenos momentos de reconhecimento mostram que a solidão não é tão só assim.

A Larissa Primo pelas risadas, pela boa companhia e por sempre poder contar se precisar de algo, especialmente se esse algo for uma poesia (ou uma biscoitada).

Agradeço à Edna Sampaio pela boa disposição em ajudar, pelas vezes que me tirou de alguns sufocos institucionais porque não fazia ideia de como proceder e pelo carinho no tratamento. Parte fundamental do departamento não apenas no sentido operacional - o que já seria muito -, mas por ser alguém com quem se pode contar. 
Aos meus amigos que fiz na escola de dança Franciene Ribeiro, João Melo, Anne Risso, Priscila Rocha e Letícia Diaz pela companhia constante e pelas risadas, deboches econversas sobre assuntos diversos. E também, é claro, pelas danças e pelos ensinamentos.

A Patricia Jasiocha pela escuta e pela amizade sempre presente, pelo carinho e pelo cuidado mútuo ainda que estejamos separados por um oceano.

Aos meus alunos de antes e de agora, especialmente, Ricardo, Thereza, Claudia, Antônio, Márcia pelas trocas

Aos amigos do Grupo da Floresta, Irlim, Vania, Iasmim, Priscila, Carlota e Rodrigo pelos almoços e pelas conversas.

Aos amigos do Sunset Lentilha, Alyne, Ronaldo, Jéssica, Juliana Moraes e Ádamo da Veiga pelas risadas e pelas saídas para o karaokê, momento de espairecimento muito necessários quando se faz uma tese.

Ao CNPq, pelo financiamento e pela bolsa durante a tese.

O presente trabalho foi realizado com apoio da Coordenação de Aperfeiçoamento de Pessoal de Nível Superior - Brasil (CAPES) - Código de Financiamento 001.

Se poderia arguir que essa tese é só um jeito muito elaborado de escrever esse agradecimento gigante. Errado não estaria. 


\section{Resumo}

Nascimento, Uriel Massalves de Souza; Andrade, Pedro Duarte. Começar pelo fim: percorrendo a formação para e pelo negativo na Fenomenologia de Hegel. Rio de Janeiro, 2021, 204p. Tese de Doutorado - Departamento de Filosofia, Pontifícia Universidade Católica do Rio de Janeiro.

A tese busca percorrer a formação para e pelo negativo a partir da leitura do prefácio da Fenomenologia do Espírito de Hegel. A escolha por essa seção se radica em dois fundamentos específicos: primeiro, nas afirmativas hegelianas de que o fim da formação é o seu começo, agora justificado. Nesse sentido, a leitura do prefácio após o fim do livro justificaria sua existência e o faria ser um desdobramento de todo o percurso da Fenomenologia. Segundo, na própria escrita fática hegeliana que, como é sabido, escreveu o prefácio apenas ao final de todo o percurso. Isso nos indica que com a finalização do livro Hegel estava em condições de escrever um prefácio que fosse, a um só tempo, começo e fim da obra que escolheu para introduzir seus leitores ao negativo e à dialética. Para que consigamos percorrer todo o trajeto, somos levados a outras obras e, também, a outros pontos da obra. Ao fim, a capacidade de leitura do Prefácio busca se tornar, então, a explicitação da formação atingida.

\section{Palavras-chave:}

Hegel; Dialética; Negativo; Formação. 


\section{Abstract}

Nascimento, Uriel Massalves de Souza; Andrade, Pedro Duarte (advisor). To begin from the end: following the process of formation to and through the negative in Hegel's Phenomenology. Rio de Janeiro, 2021, 204p. Tese de Doutorado - Departamento de Filosofia, Pontifícia Universidade Católica do Rio de Janeiro.

This thesis tries to follow closely the process of formation of the consciousness through and to the negative in Hegel's Phenomenology of Spirit. We do so by exploring Hegel's preface section to said book and we do so for the following reasons: first, Hegel himself asserts more than once that the beginning and the end are one an the same, the only difference being the fact that the end is beginning justified; secondly, Hegel himself wrote the preface (and not an epilogue, for instance) just after he finished the book, not before. Those two factors combined together seem to tell us that Hegel himself needed his own formation before he could write the section because it's rooted in the formation itself. In our theses we put forward the notion that, by the same token, if one can close read the preface, one can be said to be formed, the reading of the Preface serving as proof of the conclusion of the formative process.

\section{Keywords:}

Hegel; Dialectics; Negative; Formation. 


\section{Sumário}

$\begin{array}{ll}1 \text { Introdução } & 15\end{array}$

2. O início da empreitada 38

2.1. Excurso sobre a noção de formação 38

2.2. Parágrafos iniciais 53

2.3. Narrar sem nomear 66

3. A linguagem como negativo 77

3.1. Sistema e Ciência 78

3.2. A linguagem na Fenomenologia 94

3.2.1. A Crítica de Feuerbach 106

3.2.2. Desvio I: linguagem como negatividade e universalidade 109

3.2.3. Desvio II: Alienar, rememorar, conceituar 119

3.3. Rememoração, matemática, fim da história 129

4. Das proposições raciocinantes às proposições especulativas 135

4.1. O problema do entendimento 136

4.2. A atitude raciocinante 150

4.2.1. O sobrinho irônico de Rameau 159

4.3. A caminho do especulativo 177

4.4. O especulativo e as proposições especulativas 180

5. Conclusão: Concluir sem terminar 196

6. Referências bibliográficas 199 
Wer etwas Großes will, der muß sich, wie Goethe sagt, zu beschränken wissen. Wer dagegen alles will, der will in der Tat nichts und bringt es zu nichts [Quem quer algo de grande, como diz Goethe, deve saber limitar-se. Quem, pelo contrário, tudo quer, nada, em verdade, quer e nada consegue.]

(Hegel, Enciclopédia das Ciências Filosóficas) 


\section{Introdução}

\section{Sobrevoar o passado}

A abertura da Filosofia do Direito de Hegel contém, em uma de suas passagens mais icônicas, uma das definições que Hegel faz do papel da filosofia e de seu momento:

Sobre o ensinar como o mundo deve ser, para falar ainda uma palavra, de toda maneira a filosofia chega sempre tarde demais. Enquanto pensamento do mundo, ela somente aparece no tempo depois que a efetividade completou seu processo de formação e se concluiu. Aquilo que ensina o conceito mostra necessariamente do mesmo modo a história, de que somente na maturidade da efetividade aparece o ideal frente ao real e edifica para si esse mesmo mundo, apreendido em sua substância na figura de um reino intelectual. Quando a filosofia pinta seu cinza sobre cinza, então uma figura da vida se tomou velha e, com cinza sobre cinza, ela não se deixa rejuvenescer, porém apenas conhecer; a coruja de Minerva somente começa seu voo com a irrupção do crepúsculo. ${ }^{1}$

Ao ler essa passagem, uma ideia se destaca de maneira bastante notória das outras: a da impossibilidade de a filosofia ser atuante, de maneira direta, no mundo. Isso atesta uma separação - bastante brutal inclusive -, por parte de Hegel, de boa parte da tradição filosófica desde Platão ${ }^{2}$, que via na atuação sobre o mundo um dos caminhos e mesmo um dos direitos da filosofia. Afinal de contas, a visão de que um sábio ou rei filósofo seria capaz de governar a realidade, de guiar o curso do mundo, faz tão mais sentido quanto mais se pensa que se conhece a realidade tal e qual ela se

${ }^{1}$ HEGEL, 2010, p.44, negrito nosso.

${ }^{2}$ É curioso que seja exista mais de uma tentativa de juntar diálogo e dialética platônica à dialética hegeliana, especialmente quando os autores visavam coisas tão distintas. Na República, sem sabermos bem o porquê, o destinado a se tornar filósofo volta à caverna; a consciência da Fenomenologia do Espírito jamais deixa de olhar pra trás nem de viver com os homens, porque se sabe ali enraizada, mas jamais tem a ideia de que ela saberá governar melhor do que os governantes, por assim dizer. Isso porque já está ciente das destruições que foram causadas pela Revolução Francesa, uma revolução que em muito foi papel dos filósofos como eventualmente alguns comentadores ressaltam (CF HEGEL, 1992 e também ZIZEK, 2020). 
apresenta, como se fosse caso mesmo de a realidade se apresentar sem meandros ou dificuldades para a intelecção, como se ela fosse, ao pensador, transparente e cognoscível.

O que esse trecho mostra é que, para Hegel, não é o caso. Muito longe de se estabelecer como a legisladora do mundo ou como aquela cuja atuação é copresente ao próprio mundo, a filosofia somente fala de qualquer processo que nele ocorre no momento em que ele se acabou, ficou velho, não é mais atuante. Em uma sentença: permite sua compreensão lógica, termo que adquire sentido bastante específico em sua filosofia. Em suma, no momento em que aquilo de que se fala já cumpriu seu papel e já fechou seu ciclo - esta última a imagem constantemente usada por Hegel para ilustrar sua compreensão da filosofia ${ }^{3}$ - a filosofia entra em cena. Uma teoria que é réquiem, portanto, não tanto um anunciar retumbante do espírito: eis a imagem de Hegel para o ato de filosofar.

Uma tal definição da filosofia de Hegel pode parecer estranha, especialmente se pensada à luz de formulações bastante entusiasmadas de sua Fenomenologia. Afinal, é na seção prefácio da referida obra que lemos uma frase exortativa como "a filosofia pode deixar de se chamar amor ao saber para se chamar saber efetivo"4 quer dizer, não existiria momento melhor do que o presente da escrita de Hegel para a realização da filosofia. O presente seria, então, o momento por excelência no qual a filosofia poderia finalmente se tornar o que é, por assim dizer, mas nunca esteve em condições históricofilosóficas (como o trecho indica, é basicamente o mesmo) para tanto. Como seria no presente e somente no presente que a filosofia poderia se tornar consciente de si, seria esse o seu tempo de existir em todo o seu resplandecer. Hegel seria aquele que realizaria a filosofia, escalando gradativamente os ombros de todos os gigantes que o antecederam.

Mas isso é apenas uma análise do que seria, digamos, o espírito da filosofia de Hegel e não a sua letra. A execução concreta da filosofia de Hegel, especialmente aquela que se dá em sua Fenomenologia, conta uma história bastante diferente dessa, especialmente na seção do prefácio. Lá vemos toda a definição metodológica hegeliana

\footnotetext{
${ }^{3}$ E daí frases que veremos retornar várias vezes ao longo desse trabalho como "círculo de círculos", "o começo é o fim e o fim é o começo como no círculo" dentre outras.

${ }^{4}$ HEGEL, 1992, p.23.
} 
e, curiosamente, já nos damos conta de que a seção foi pensada para ser lida tanto ao começo da obra quanto ao fim já que ela é, simultaneamente, seu fim e seu começo. Não só: nesse segundo momento da leitura, o leitor teria os ganhos e avanços oriundos de sua primeira leitura e teria, com isso, uma posição outra, posto que já compreenderia os termos ali colocados não apenas como noções às quais ele é estranho ou que conhece de maneira abstrata, mas como estrutura da própria realidade e de seu pensamento, a ser depurada e melhor desdobrada na Ciência da Lógica. ${ }^{5}$ Isso foi observado de maneira muito direta por Gadamer. Em seu brevíssimo comentário à seção, ele nos elucida que "esse prefácio [da Fenomenologia] foi escrito como uma introdução ao sistema planejado a partir das duas partes de uma Fenomenologia do espírito e de uma Lógica e metafísica."

Decorre daí que mesmo na primeira leitura do começo da obra, a sucessão de proposições parece ter justo por finalidade alertar o leitor contra uma tentativa muito apressada de filosofar sobre o presente, de enunciar coisas sobre ele de maneira displicente ou de não compreender a sucessão histórica dos sistemas ${ }^{7}$. Tudo se passa, portanto, como se o objetivo de Hegel já nessa seção inicial fosse, a um tempo, iniciar e terminar a formação de seu leitor. Se é no momento da escrita de Hegel que se abre à filosofia a possibilidade de sua realização, tal situação se dá apenas na medida em que ela buscar outra forma de pensar seu caráter formativo. Isso significa duas coisas, pelo menos: a primeira é analisar a carga histórica que a tradição já nos lega quando iniciamos a falar de algo como a filosofia; a segunda é aprender a pensar a partir do esclarecimento e do reconhecimento da formação que nos impulsiona.

Para a consecução de ambos os objetivos, Hegel nos mostrará que será necessário repensar o que a filosofia tem tradicionalmente entendido por seu movimento e ofício, a saber, a função de descobrir os fundamentos da realidade, tarefa geralmente chamada de conceituar. Fará isso ressignificando a relação disso com a linguagem e, também, com as posturas éticas que uma conceituação deve

5 Muito tempo depois da elaboração dessa introdução e durante sua revisão, uma feliz confluência, oriunda do que só pode ser chamado aqui de acaso feliz, trouxe ao meu conhecimento uma dissertação de uma amiga e pesquisadora que tem a exata mesma tese, apenas aplicada à Ciência da Lógica. Cf. MASTRO, F, 2021.

${ }^{6}$ GADAMER, 2012, p.102.

${ }^{7}$ Como ficará claro quando examinarmos, parte a parte, o início do prefácio. 
necessariamente englobar. Será necessário, além disso, abrir mão da possibilidade de se falar da contingência enquanto presente, salvo em uma situação, a saber, na Ciência da Lógica, momento no qual a contingência gradativamente cai dos conceitos. A formação para a filosofia ou para a ciência em Hegel é, então, uma formação que abdica completamente da dimensão contingencial porque ela é sempre fugidia, passageira, efêmera. É preciso que exista uma espécie de corrente lógica que guia tanto pensamento e realidade para que, ao compreender o primeiro se compreenda também a última. Para Hegel, essa corrente é justo o conceito.

Dito isso, nos detenhamos um pouco, por questões didáticas, no que vai significar a conceituação na obra posterior para pensarmos por contraluz. Ao fim e ao cabo, é para essa obra que a Fenomenologia nos forma, afinal.

\section{Lógica e história conceitual}

A Ciência da Lógica visa justo demonstrar para o leitor a estrutura do pensamento no geral enquanto este mesmo pensamento ocorre. A grande dificuldade da leitura, nos diz Hegel, decorre em grande parte disso: que a estrutura que esteja em jogo na hora de compreender a lógica seja o desenvolvimento do próprio pensamento no mesmo momento em que ele ocorre ${ }^{8}$. O livro tende a buscar uma reduplicação da consciência ${ }^{9}$ pelo fato mesmo de que a noção que aparece projetada no livro não é apenas algo estranho ao sujeito ou diferente dele, mas seu próprio pensamento e seu processo de pensar objetivados. Se fôssemos dizer de outra forma, poderíamos afirmar que a dificuldade destacada por Hegel da Ciência da Lógica é justo que ela ocorre ao mesmo tempo em que se pensa, ou seja, é copresente ao pensamento e tenta capturar sua estrutura. É como se se estivesse tentando olhar, a um só tempo, o olho com o próprio olho.

Ora, é justo na referida obra que Hegel faz questão de excluir qualquer concreção e, também, qualquer contingência. Por isso, ali, lemos que diante de nós temos o pensamento de Deus, da criação do mundo antes da concreção e dela

${ }^{8}$ HEGEL, 2016, pp.33-38. Nesse caso específico, todo o prefácio tem esse tom, mas não o referimos por completo.

${ }^{9}$ MASTRO, 2021. 
apartado $^{10}$. A estrutura lógica, nesse sentido, não versa sobre o mundo efetivo, com sua materialidade e temporalidade intrínsecas, mas sobre a lógica a partir da qual essa própria materialidade se estrutura. Se tomamos uma postura de leitura não metafísica que interpreta isso como uma exacerbação do kantismo e da crítica das categorias metafísicas (Longuenesse, Pippin, Lebrun), ou se tomamos isso como uma metafísica por excelência (Heidegger e, em algum grau, Adorno), é pouco relevante para essa questão específica. Se se mantém o fato de que se pode dizer que "a história realiza a Lógica" como o fez mais de um comentador ${ }^{11}$, só se pode fazê-lo porque se tem a noção de que esta e aquela têm diferenças, sendo a maior delas, justo, a presença da contingencia. Realizar não significa outra coisa que tornar concreto, efetivo, material e conferir a isso uma duração específica. Em outras palavras: realizar significa tornar-se temporal e, por isso, finito. Se um gracejo poético nos for permitido, é tornar as coisas poeiras lançadas aos ventos do tempo.

Segue-se daí que a possibilidade de existência de um momento no qual se possa pensar o presente enquanto ele ocorre, dependerá de uma suspensão da contingencia e de um deslocamento de foco para a apreensão do que é o pensamento conceitual. Seguindo Mastro, para a exata compreensão da obra que é a Lógica é preciso então que a consciência descubra o que sempre esteve lá: sua identidade com o que ela colocava como algo externo porque escrito, como algo distanciado porque objetivado em páginas, algo radicalmente outro porque não visto como si mesmo. ${ }^{12}$ A pergunta que advém daí pode ser tão simples quanto: mas como isso elucida a Fenomenologia?

Pois bem, a Fenomenologia parte do pressuposto exatamente contrário ao da Lógica $^{13}$. Se esta já pressupõe uma série de ganhos nos quais entre pensamento e realidade e entre consciência e mundo, existe uma relação de identidade, aquela busca explicitar o movimento intrínseco ao pensar e à realidade enquanto eles ocorrem. Nesse sentido, a Fenomenologia precisa contar com a concreção, especialmente naquele que

\footnotetext{
${ }^{10}$ HEGEL, 2016, p.61-62, especialmente a sentença “O sistema da lógica é o reino das sombras, o mundo das essencialidades simples, libertado de toda concreção sensível”.

${ }^{11}$ E.g. Marcuse ao longo toda a parte um de seu Razão e Revolução quando trata de história.

12 MASTRO, 2021.

${ }^{13}$ Daí o final da Fenomenologia possuir um parágrafo como: "No conceito que se sabe como conceito, os momentos se apresentam, pois, anteriormente ao todo implementado, cujo vir-a-ser é o movimento desses momentos. Na consciência, ao contrário, é anterior a esses momentos o todo, mas o todo não-conceituado" HEGEL, 2000.
} 
vai vir a seu segundo volume, versando mais propriamente sobre o Espírito Absoluto e sua História. Tomar a consciência e levá-la como que pela mão de sua experiência hodierna até ao pensamento que a equaciona com a realidade precisa passar por aquilo que será chamado, no trecho da filosofia da história que fica conhecido como Razão na História, de história filosófica ${ }^{14}$. Assim, por mais que Hegel somente defina e desdobre essa história de maneira detida em um de seus cursos, é nela que ele se baseia para conceber pelo menos esse segundo momento da Fenomenologia. ${ }^{15}$ Nesse sentido, Forster é certeiro em sua tese geral: Hegel apenas desdobrou melhor em seus cursos aquilo que já estava presente na Fenomenologia ${ }^{16}$, razão pela qual a leitura daqueles a ilumina em termos efetivos.

Visto sob esse prisma, é possível compreender como, já na Fenomenologia, mesmo para vaticinar sobre qualquer assunto do presente a filosofia sempre chega tarde demais. Afinal, se o efetivo está se dando no presente e se a formação da consciência precisará passar pelos inúmeros desenvolvimentos históricos para compreendê-lo de maneira própria; se só existe verdade na totalidade e na compreensão do desenvolvimento desta; se, por fim, o momento presente ainda não está acabado, posto ser presente, e, portanto, imerso em contingência; então, já estamos atrasados e só nos restam duas opções de lida com esse problema.

Uma opção seria advogar pelo fim concreto e efetivo da história, e levar essa frase às últimas consequências. Viveríamos, nesse sentido, uma espécie de prorrogação infinita de uma história que não teria mais nenhuma circunvolução a mostrar. Todos os processos estariam acabados e só nos restaria seguir sem crer que as mudanças existam. Essa foi a opção de alguém como Fukuyama, embora aplicada ao mundo pós queda do comunismo. ${ }^{17}$ Nesse sentido e apesar de todas as modificações de realidade concreta,

${ }^{14}$ HEGEL, 2010, p.16.

${ }^{15}$ E dizemos "pelo menos" porque temos, por exemplo, o trabalho de Hyppolite, que tenta justo demonstrar como é possível ver uma dimensão histórica também na primeira parte. Cf. HYPPOLITE, J, 1974.

${ }^{16}$ FORSTER, 1998.

${ }^{17}$ Não entraremos em detalhes sobre sua concepção de fim da história. Basta aqui que saibamos que ele aplica a tese do fim da história hegeliana a ausência de alternativas sistêmicas globais decorrente do mundo exclusivamente capitalista no qual vivemos. Sua hipótese surge, não por acaso, após a queda do muro de Berlim, momento que marca a queda do regime de oposição ao capitalismo - com todos os problemas que isso tem - que foi a USSR. Cf., para mais detalhes FUKUYAMA, 1992. 
a ênfase no fim da história coaduna com a ideia do pensamento de Hegel autorizar um pensamento sobre o presente.

Note-se, aí, que a história se enraíza numa noção de história do contingente finito e perde seu caráter lógico. Se torna, por assim dizer, uma afirmação denotativa demais e hegeliana de menos. Em Hegel, como já dissemos e como veremos melhor ao longo da tese, o finito, porque contingente, somente passa e se desdobra: nada mais. Não há uma história filosófica do efetivo per se: dele, enquanto ocorre, nada se fala de valor lógico poque nada se pode falar. Sendo assim, não nos parece a opção mais adequada posto entrar em choque direto com a construção hegeliana de história.

Outra opção seria ressaltar que o pensamento de Hegel não dá conta do presente, sendo antes uma crítica da metafísica e uma história do Espírito por excelência. Nesse sentido, enfatizaríamos, com alguns comentadores (Lebrun, Longuenesse, Zizek, Safatle), a dimensão de crítica da metafísica da filosofia de Hegel, ao mesmo tempo em que aplicaríamos ao próprio autor um pressuposto de leitura depreendido da reflexão contida na citação que iniciou esta introdução. O critério para que sua obra que versa sobre concreção possa ser compreendida como filosófica é precisamente aquele de somente versar sobre a formação do presente, o próprio presente ficando vedado à compreensão e sendo um aberto infinito sobre o qual nada se pode ou se quer falar. A história lógica do presente e as experiências de leitura sobre elas estariam alinhadas num mesmo escopo, uma vez que toda consciência já estaria lendo sempre de maneira assíncrona com a obra. Em bom português, a obra já foi escrita e, portanto, já é parte da história da filosofia - se seria bem recebida ou não, era caso de Hegel apostar, mas a má recepção não torna algo não histórico.

Essa última posição, por inscrever o próprio movimento de leitura e formação dentro dos pressupostos de Hegel nos parece consequente com a postura que Hegel esposa ao longo da obra, posto apostar no caráter histórico-lógico de sua reflexão. Por isso, será uma tal visada que adotaremos. Sub-repticiamente, deixamos enunciado aqui, então, mais um dos porquês de nossa escolha pela análise da formação como algo central à obra que aqui será analisada: também a leitura do livro já é contável como um capítulo da formação e, sendo ele um livro circular, ele pode ser compreendido à luz da história que ele mesmo conta. 


\section{Entre enunciação e enunciado}

Nossa posição, então, é aquela que exclui a possibilidade de Hegel pensar um tempo do agora, sendo mesmo possível enuncia-la de maneira radical como dizendo que Hegel sequer pensa o tempo - bastando para isso tomarmos esse último como presente/passado/futuro. O próprio fato de que o presente é um constante e incessante presentificar-se, posto ser contingência, já impediria tal coisa, razão pela qual a adoção de uma filosofia da retrospecção, que se confunde com a história filosófica, seria adotada.

Ademais, a imagem de um pássaro que só se lança ao voo ao fim do dia para somente observar (visto ser incapaz de alterar a realidade) nos parece mostrar também outra característica da filosofia desde o ponto de vista hegeliano: a do fato de não ser uma intervenção direta na realidade com vistas a alterá-la de maneira direta e substancial, se limitando a alterar às consciências que toca com a exata apreensão da dimensão de passado que opera no presente. $^{18} \mathrm{~A}$ educação, de que falávamos no começo, tem assim um caráter de educar sobre o que já se sabe. Essa é outra forma de dizer que "o que é conhecido nem sempre é reconhecido" $"$. A história conceitual presente na Fenomenologia serviria, então, não como um processo educativo puramente enciclopédico, no qual novos conhecimentos são adquiridos, mas como uma educação acerca da lógica imanente desses processos e de seu desdobramento na realidade. A articulação lógica dos eventos seria a força motriz do processo de reconhecimento. Não basta saber da existência de determinados eventos históricos, é necessário também saber a articulação que eles têm entre si e seu enlace na formação do Espírito. Saber o que já se sabe é, portanto, reconhecer o que se vive e esse nos parece ser a maneira pela qual Hegel procede ao longo da obra, seja no capítulo introdutório quando versa sobre Kant, seja no prefácio quando toma um prefácio como seu objeto.

Por isso, podemos dizer com base no que já construímos até aqui, que a apreensão conceitual histórica em Hegel tem, em sua própria natureza, o descompasso

\footnotetext{
${ }^{18}$ Para uma discussão disso mais aprofundada, cf. ARANTES, 1996, p.388.

${ }^{19}$ HEGEL, 1992, p.37.
} 
com a realidade, de modo que sempre já se chega muito tarde para se fazer algo. Ademais, ela também é, num certo sentido, atuação direta no material explorado, de modo que ela também é geratriz de uma forma de compreensão da realidade. Isso parece ter grandes consequências na reflexão de Hegel sobre a proposição e a linguagem, de modo que estas precisarão ser reformuladas para comportar a sua forma de filosofar que apresenta, ao mesmo tempo, lógica e história ou, se se preferir, a lógica imanente à história.

Nesse contexto, o tropo "filosofar é rememorar" que citamos acima adquire um sentido bastante preciso: a filosofia sempre sobrevoa escombros, porque é somente assim que sua linguagem ganha azo e sua definição de conceito, sentido. $O$ fato de que a filosofia possa falar de algo exige, então, que esse algo já esteja acabado, o pálido cinza atestando a ausência de vida que o corpo da coisa a se falar transmite. Curiosamente, entretanto, a filosofia não apenas faz uma espécie de autópsia; antes, reinjeta a vida perdida na coisa, de modo que confere dinamismo ao processo acabado, como que restaurando a vida que tinha no momento de sua existência. Dito de outra maneira, se a filosofia é sobre o passado, é porque ele não está morto: ele é quem comparece constantemente no presente, fazendo ver sua inquietante presença lá mesmo onde já se cria que ele não mais retornaria. É como um fantasma que insiste em não ser expulso, não importa quais rituais se faça para exorcizá-lo. Temos, assim, uma filosofia que inicialmente se pretende cinza, mas que vivifica aquilo mesmo de que fala e, por se dirigir sempre ao presente do qual fala como algo irresistível, foi acusada de dar a aparência de um certo triunfalismo.

Se fomos bem sucedidos até aqui, nossa hipótese parece bastante distante da imagem de conclusão apoteótica e espetacular das histórias do mundo que corre sobre Hegel: se a história aparente se concluir de modo apoteótico é porque, no fundo, ela já se concluiu, ela já acabou, a morte do objeto sobre o qual se fala já ocorreu. O discurso filosófico é apenas a maneira de mostrar como o morto ainda vive apesar do seu corpo ter se despedaçado. A filosofia se transforma, assim, numa gigantesca obra de luto ${ }^{20}$,

20 Talvez essa expressão cause certo estranhamento, já que a totalidade comparece vivamente na obra hegeliana. Mas há que se pensar, como faremos à frente, que o luto não pressupõe perda, mas morte e ressignificação. A frase recorrente em filmes blockbusters que diz que o morto "sempre estará 
que tenta elaborar o objeto perdido a partir de um discurso que faça dele algo vivo. A apoteose sentida é fruto do momento do qual se fala. Afinal, quando contamos uma história, ocupamos sempre um lugar de descompasso entre já saber seu fim e estarmos contando seu desenvolvimento. É desse descompasso que vem o ar de triunfalismo.

\section{Luto sem melancolia}

Para qualquer um que já esteve dentro de um processo de luto, não deixa de ser nunca fonte de curiosidade o fato de que o objeto que se abandona pareça retornar sob mil faces e pareça se fazer presente a cada pequeno momento ${ }^{21}$. Assim sendo, o presente é sempre tomado de assalto por esse passado, como se um corte na sucessão normal do tempo se tornasse uma realidade muito próxima e concreta e, em algum grau, até mesmo assustadora. A possibilidade de falar sobre o passado e conferir a ele um lugar, a partir da fala, será sempre a melhor chance do enlutado de entender o que foi que perdeu. É preciso um olhar de retrospecção que seja capaz de deslocar aquele passado e introduzir uma negatividade (no sentido filosófico) entre o objeto e o sujeito enlutado $^{22}$, introduzindo com isso também uma certa articulação lógica. Tudo isso a partir da ressignificação de um passado e a partir, também, de uma sucessão de falas sobre ela no presente. O objeto é abandonado de seu caráter concreto real ${ }^{23}$, e passa a se tornar apenas memória ${ }^{24}$. A compreensão das lógicas de articulação e construção desse objeto por parte do sujeito, i.e., como esse objeto aparece para mim e o que ele significa, permitem uma liberação daquele que dele fala. Em linguagem mais simples, num luto bem sucedido o objeto não mais captura o indivíduo, não lança sobre ele sua sombra; antes, é abandonado em sua materialidade finita e, por não ser mais material, não pode mais sombrear nada.

Não nos parece ser por acaso, portanto, que o réquiem que é a filosofia hegeliana não pode ser outra coisa do que uma história que precisa passar em revista

em seu coração" apesar de piegas e clichê mostra aqui seu grau de verdade - o que, aliás, toda pieguice clichê resguarda.

${ }^{21}$ FREUD, 2006, p.250.

${ }^{22}$ FREUD, 2006. p.250.

${ }^{23}$ Diríamos com Hegel: contingente.

${ }^{24}$ Com Hegel de novo: conceito. 
por seus eventos para se realizar. A figura do Espírito que sai de sua imediatez e retorna mediado e reconciliado ${ }^{25}$ é concluída, não por acaso, nessa passagem em revista da história para entender seus pontos principais, o quanto ela ainda atua no presente, ao mesmo tempo em que restitui o lugar de tudo aquilo que parece superinflado, hipostasiado ou simplesmente pretensioso. Derruba, com isso, à importância do contingente, não pelo enfrentamento, mas pela sua adoção e depuração. É também a chance de localizar certos momentos como o que são efetivamente: momentos de uma história maior e não a versão final de quaisquer coisas.

Assim, o sobrevoo da coruja de Minerva não é outra coisa que a tentativa de Hegel de mostrar como a história da liberdade até ali, apesar de ter acabado, não cessa de estar viva, tampouco cessa de pulsar enquanto concreção para a consciência formada. A imagem do passado como círculo de degraus ${ }^{26}$ da Weltgeschichte - cuja atualização poderíamos fazer nas figuras de Escher - é justo a tentativa de ilustrar o quanto o passado se marca e se faz presente de modo que para Hegel é obrigação de um discurso filosófico extrair o que há nele de vivo se ele quiser ser chamado de filosofia.

O procedimento é, assim, duplo: por um lado, Hegel somente pode constituir sua filosofia se pressupuser a morte de tudo que fala e, por tabela, se assumir explicitamente a impossibilidade de se falar da contingência. A filosofia se torna olhar em retrospecção, algo que anos mais tarde será violentamente criticado um autor como Nietzsche. Por outro lado, a passagem por essa vida já acabada é uma demonstração objetiva de que o término não significa fim, vez que ainda existe vida pulsante nesse passado, bastando saber de que modo perguntar sobre ele.

O processo que chamamos de luto, ancorados em Freud, não é um processo de abandono absoluto do objeto, posto que ele constitui parte da vida do enlutado e ainda assim será quando do "término" de tudo; antes, é um processo de distanciamento e modificação do investimento que ocorria, sendo um modo deixar o objeto ir e deixarse ir também a partir dele. Existe uma similaridade lógica entre o luto freudiano e o procedimento filosófico hegeliano, posto ambos teorizarem sobre um abandono de

\footnotetext{
${ }^{25}$ E sua história está tanto presente na Fenomenologia, quanto descrita ou deduzida longamente na Enciclopédia.

${ }^{26}$ HEGEL, 1986, p.105.
} 
certo objeto que se foi para melhor incorporá-lo na existência desde a visada da memória. Lendo Hegel através de Freud e mantendo as proporções (Freud fala do psiquismo individual, afinal) podemos compreender esse aspecto da filosofia hegeliana por uma visada diferente, que nos parece implícita em Hegel. Parece-nos que ambos estão sinalizando que o abandono do objeto e sua morte não são formas de sua extinção, mas de sua permanência de forma permanente. É como se a morte do objeto o inscrevesse definitivamente no psiquismo, uma segunda morte sendo, na verdade, o mais próximo do que seria sua ressurreição.

A dinâmica é meramente um dos aspectos da dialética: aquele que a crença no espírito prático, no ato dominante, na infatigável capacidade de fazer enfatiza preferencialmente, pois a renovação perene oculta da melhor maneira o antigo não verdadeiro. O outro aspecto menos popular da dialética é o estático. (...) A compulsão, sob a qual ela conceitua o desdobramento incansavelmente destruidor do sempre novo, consiste no fato de que o sempre novo é, a todo instante, simultaneamente o antigo visto de perto. ${ }^{27}$

Se Habermas pôde dizer que Hegel tem o primeiro conceito adequado de modernidade ${ }^{28}$, nos parece ser justo porque o filósofo da Suábia reconhece que a modernidade filosófica só pode ser plenamente compreendida se contraposta aos tempos anteriores e se vista como uma decorrência e um desenvolvimento deles, ou seja, se houver uma linha lógica que faça com que todo o processo que se chama filosofia (ou arte, história mundial, religião, etc.) seja um desenvolvimento da verdade sendo, com isso, mais do que uma simples coletânea de saberes e sistemas dispersos. A filosofia se torna história da filosofia mesmo lá onde ela é Lógica ${ }^{29}$, pois o desenvolvimento toma a frente e, tendo em vista que é história, ele só pode ser exposto com palavras, uma vez que elas são a única forma aceita por Hegel de exposição filosófica.

Hegel é enfático em negar a posição da intuição ou de quaisquer apreensões que não sejam feitas por palavras, igualmente enfático em falar ou usar a linguagem

\footnotetext{
27 ADORNO, 2020, p.260.

${ }^{28}$ HABERMAS, 2000, pp. 24-26.

${ }^{29}$ Para um desenvolvimento dessa tese, cf. NOLASCO, 2015.
} 
para sua demonstração ao longo da Fenomenologia ${ }^{30}$. A própria imagem do círculo, por ele diversas vezes evocada, já o coloca em posição inversa àquela do mutismo de fim de processo: o fim do processo não é sua extinção ou término, mas a justificativa de seu começo e, como é processo de reconhecimento, é apenas um processo visada compreensiva do que já se sabia, agora tendo isso reconhecido. Como é tema central para nós, explicaremos de maneira mais detida e exaustiva, adiante, como a linguagem é fundamental a Hegel.

A hipótese que havíamos aparentemente abandonado no começo como uma tomada de caminho diante de uma bifurcação retorna aqui como uma espécie de complemento àquela que tinha sido nosso caminho. A ideia, então, não é tanto que não se possa falar do presente, mas que não se pode falar dele diretamente posto que o passado também nele pulsa. Sendo ainda mais radicais: falar do presente é necessariamente falar do passado.

Eis aí nosso problema: como é possível a Hegel expor um tal empreendimento e desenvolve-lo se tem por objetivo, entre outras coisas, educar e formar (é o problema da Bildung) as consciências de seu tempo?

\section{Dialética, linguagem, temporalidade}

Com isso, nos resta uma ponderação quanto aquilo que se poderia chamar de estruturação hegeliana da realidade, a saber, sua dialética e a construção de Hegel do que chamou de pensamento especulativo. Pois é sabida e já foi por nós citada a ênfase do autor na ideia de que com ela estaria descrito o movimento da realidade contingente, mas o do próprio Deus ${ }^{31}$, antes mesmo de qualquer contingência pudesse se enunciar, ou seja, no pensamento de Deus as coisas se passariam de maneira puramente lógica, sem que a realidade material efetiva estivesse presente. Se é assim, a linguagem teria que ser capaz de expor precisamente uma tal dialética, sendo capaz de fazer seus movimentos ao mesmo tempo em que os torna inteligíveis a quem lê. A linguagem teria, portanto, que ser ela mesma dialética, o que aparece para alguns comentadores como uma dificuldade quase insolúvel. ${ }^{32}$

\footnotetext{
${ }^{30}$ KOYRÉ, 2011, p.205.

${ }^{31}$ Cf. nota 8.

${ }^{32} \mathrm{CF}$. a esse respeito COSSETIN, 2012.
} 
É essa imersão profunda na experiência do negativo, experiência essa que Hegel enraíza no uso da linguagem ${ }^{33}$ como demonstração e desenvolvimento necessários do conceito, que torna qualquer comentário ou crítica algo muito mais difícil $^{34}$. Comparando por contraluz um fracasso e um sucesso: qualquer um que já se apaixonou ${ }^{35}$ atesta com facilidade que a construção linguística sempre parece aquém da experiência vivida. Não importa quão rico seja o vocabulário do apaixonado: sempre parece restar algo por falar. A linguagem pode por vezes parecer não dar conta daquilo mesmo que foi vivido, a menos que seja feito um trabalho constante sobre ela - e, em inúmeros momentos, nem mesmo assim. Existe sempre o déficit entre a experiência vivida e a capacidade expressiva da linguagem, fica sempre uma espécie de buraco, uma espécie de impossível não expresso, mas presente. Essa experiência é da mesma lavra que o negativo do qual Hegel fala.

O amor serve, aqui, como experiência modelo de comparação especialmente porque, nele, estamos sempre além ou aquém do objeto amado, tentando constantemente negar a negatividade na qual estamos imersos, sem nos darmos conta de que é ela mesma que define o sentimento amoroso. Pois amar não é o encontro de completude eterna ou de descoberta do fundamento, mas necessariamente a perda do próprio fundamento frágil que se supunha possuir ${ }^{36}$.

Mais uma analogia com o amor é possível para esclarecer a tese a ser defendida aqui. O problema fundamental do amor, como o da escrita de Hegel, é a impossibilidade de copresença entre o falado e o sentido. Todo texto de amor parece não dar conta, quer por sua beleza, quer pelo momento em que chega, de compreender o sentimento descrito e abarca-lo em sua totalidade. $O$ amante se vê diante de uma coisa muito maior do que é capaz de conceber em palavras ou, se se preferir, de um excesso muito maior do que é capaz de conter com sua linguagem, por rica que seja. Sua falha não se dá antes da tentativa de escrita ou fala, nem depois dela; antes, é a consequência

${ }^{33}$ AGAMBEN, 2006.

${ }^{34}$ ADORNO, 2007, p.72.

${ }^{35} \mathrm{O}$ uso do amor, aqui, foi feito porque também Hegel o abandonou como solução às cisões da modernidade. Não é gratuito. Sobre isso, Cf. KOYRÉ, 2011, especialmente p. 152.

${ }^{36}$ E o movimento que Hegel descreve, segundo o qual ir ao fundamental (zu Grund gehen) é ir em direção à ruína (zugrunde gehen) faz um sentido muito mais próximo ao coração aqui - com o perdão do jogo de palavras. 
mesma da tentativa de escrever. Assim, a falha do procedimento se anuncia no momento mesmo em que a pessoa que o opera se julga capaz de realizar seus pressupostos. Afinal de contas, se amo e escrevo sobre o amor, suponho necessariamente que entre meu produto linguístico e meu sentimento é possível uma relação adequação. Mas é precisamente o fracasso disso que toda carta de amor parece testemunhar no momento em que é concluída e, posteriormente, enviada. As dúvidas posteriores acerca do impacto dessa carta no amado não dizem outra coisa além da incerteza frente à verdade. Tal incerteza se manifesta depois de algum grau de certeza, combustível necessário à composição da missiva. Em suma: a certeza motiva a escrita e, pelo fato de a escrita ser a materialização de uma insuficiência antes no máximo intuída, acaba por gerar incerteza.

O que ocorre aí, em termos hegelianos, é que se tenta apreender o presente efetivo enquanto ele ocorre. A impossibilidade testemunhada e experenciada pelo amante é análoga aos fracassos contidos nos arcos iniciais da Fenomenologia, o que compreende todo o volume um. Todo esse volume uma história desse fracasso que é formativo para a consciência e a propulsiona a dar um passo além e tentar de novo. Toda artimanha hegeliana nesse volume é para mostrar que o presente excede e muito a conceitualização estanque à qual se está acostumado. O presente é contingente, móvel, vivo e, portanto, contraditório ${ }^{37}$. Mas é, ao mesmo tempo, formado de um passado sem o qual ele nem sequer pode surgir. É um precipitado último de uma cadeia de necessidades. Por ser contingente, não se pode ter certeza sobre ele; por não tanto ter quanto ser uma história, é passível de compreensão.

Ademais, mantendo a analogia com a carta de amor, se o amante tenta apreender o porquê de seu objeto amado ser digno de seu amor, ele passa a descrevê-lo de maneira objetiva, como as características das quais falasse estivessem presentes naquele objeto do qual fala. Se busca descrever o seu próprio amor e o que ele sente, volta-se gradativamente apenas para a afetação que o outro nele causa, deixando intocado o

37 “'O botão desaparece no desabrochar da flor, e poderia dizer-se que a flor o refuta; do mesmo modo que o fruto faz a flor parecer um falso ser-aí da planta, pondo-se como sua verdade em lugar da flor: essas formas não só se distinguem, mas também se repelem como incompatíveis entre si. Porém, ao mesmo tempo, sua natureza fluida faz delas momentos da unidade orgânica, na qual, longe de se contradizerem, todos são igualmente necessários. É essa igual necessidade que constitui unicamente a vida do todo" HEGEL, 1992, p. 22, negrito nosso. 
objeto. Em suma, descreve o objeto sem perceber que o constrói (a partir do amor, ou seja, de si mesmo), ou descreve a si mesmo amando sem perceber o objeto a sua frente (o que só é possível porque há um objeto a amar).

O sucesso do qual falamos é a solução que Hegel oferece a isso: o problema não está em juntar mais uma vez a cisão; antes o problema está no fato de as coisas serem compreendidas como cindidas e estanques. É necessária uma mudança de posição frente a isso. Mas quando ela ocorre, a consciência ressignifica o que entende por conceituar. As formas estanques do entendimento são dialetizadas e, por isso, a realidade é vista como existindo como desenvolvimento, ou seja, em negação constante de si. Com isso, compreende-se que só se pode filosofar sobre um processo efetivo, com realidade material e capacidade de modificação de mundo, quando ele pode ser pensado como histórico-lógico, i.e., quando acabou. A linguagem propriamente filosófica deverá ser capaz de refletir essa mudança não por um conceito que busca sempre dizer a mesma coisa sempre que aplicado - posto isto ser uma abstração e não levar em conta o desenvolvimento -, mas por uma noção de conceituar que não petrifique palavras num sentido unívoco. Uma tal noção terá incorporada em si o desenvolvimento ocorrido, de modo que o todo se desdobrará pari passu as ressignificações. Como a consciência que lê é formada dentro do Espírito sobre o qual lê, a consciência aprende que o conteúdo que toma como objetivo, como uma fala sobre algo é, na verdade, uma fala sobre ela mesma. A consciência descobre que é, então, o Absoluto conhecendo-se. ${ }^{38}$

\section{A hipótese propriamente dita}

A Fenomenologia, por ser uma obra que busca traçar uma ponte entre a materialidade e o lógico, precisa se estruturar formalmente de modo que dê conta de uma dupla inscrição em uma e outra simultaneamente num movimento de vasos comunicantes. Isso porque Hegel precisa traçar uma tal ponte para que a consciência, estando formada, possa finalmente apreender o lógico no efetivo e, doravante, possa compreender a estrutura lógica inerente à história.

\footnotetext{
${ }^{38}$ Essa temática é similar àquela de Schelling, afinal, o Absoluto precisa me incluir para Ser assim pensando. Para uma leitura sobre essa temática em Schelling, BEISER, 2012, especialmente p.592.
} 
Sendo assim, a estrutura do seu livro não pode deixar de ser pensada como também parte da obra, pelo simples fato de que o que pressupõe como desenvolvimento não é uma linha ascendente, mas um círculo que é traçado conforme o leitor vai lendoo. A forma deve ser uma com o conteúdo. Desse modo, o começo deve se confundir com o fim e este último àquele deve retornar quando do término da obra. Se o objetivo central de sua obra é uma formação a partir da análise dos processos históricos de formação, é preciso que a estrutura formal do livro abarque seu projeto.

Ademais, se pensarmos que, para ele, a consciência possui um todo não conceituado que ela como que vê se preencher ao longo de seu processo formativo, é preciso que Hegel seja capaz de fornecer esse mesmo todo antes mesmo de o livro começar. É preciso, então, que esse todo seja, ao mesmo tempo, passível de ser lido de maneira não conceitual e que apareça justificado completamente ao fim da leitura do livro, ou seja, ao fim do capítulo sobre o Saber Absoluto. A seção escrita logo após o término do livro, o Prefácio ${ }^{39}$, nos parece ser o locus central a partir do qual uma tal junção é feita. Se é assim, essa seção deve servir como um guia de leitura para a Fenomenologia ${ }^{40}$ por pressupor, ao mesmo tempo, a ausência completa de contato com a obra e a familiaridade completa com ela perfazendo assim a identidade entre a identidade e a não identidade de maneira formal ${ }^{41}$. Os pressupostos ali avançados, como esperado, se desdobram e passam a ser demonstrados paulatinamente nos capítulos que a ela se seguem. Ao mesmo tempo, praticamente todos parágrafos contidos no Prefácio são passíveis de serem compreendidos de uma maneira profundamente distinta se assumimos a totalidade da obra para a leitura deles. Assim, o Prefácio é a seção privilegiada para a nossa tese, porque ele, ao pressupor toda a leitura e introduzir a obra ao mesmo tempo, sofre o exato mesmo deslocamento que o leitor sofre ao ler a obra porque se desloca com ele. O Prefácio serviria, por isso, como um guia de leitura de toda a obra e como atestado da formação bem acabada. Para ser um livro sobre formação nos moldes que queria, portanto, Hegel começou sua obra

${ }^{39}$ Doravante, toda vez que nos referirmos a Prefácio, com $\mathrm{P}$ maiúsculo, queremos dizer: o prefácio da Fenomenologia, explicitamente. Com minúsculo, apenas a seção de um livro.

${ }^{40}$ GADAMER, 2012.

${ }^{41}$ No sentido específico de forma textual. 
pelo fim, o começo sendo indício, ele mesmo, de que um desenvolvimento formativo é necessário.

Em relação a esse último aspecto, temos no Prefácio um autor que discorrer longamente sobre as modificações que devem ser efetuadas por sua filosofia, modificações essas que não têm quaisquer fundamentos para uma consciência ingênua ${ }^{42}$, mas que se tornam a única possibilidade uma vez que a totalidade de seu projeto inicial foi percorrida e experimentada. É, portanto, uma sessão que introduz e conclui sendo, por isso, um começar pelo fim, daí o título de nosso trabalho que tenta na letra capturar a dialética inerente à seção.

Nossa tese nos parece coerente com a posição geral filosófica do autor, jamais modificada, segundo a qual o contingente é o que cai do conceito precisamente porque o contingente ali não encontra espaço ${ }^{43}$, ou seja, tudo aquilo que poderia tornar-se outra coisa, desenvolver-se de outro modo, devir de modo diferente, não possui espaço na realidade conceitual e, por isso, a fala sobre isso deve ser interditada. Também é coerente com a ideia de que

O verdadeiro é o todo. Mas o todo é somente a essência que se implementa através de seu desenvolvimento. Sobre o absoluto, devese dizer que é essencialmente resultado; que só no fim é o que é na verdade. Sua natureza consiste justo nisso: em ser algo efetivo, em ser sujeito ou vir-a-ser-de-simesmo. Embora pareça contraditório conceber o absoluto essencialmente como resultado, um pouco de reflexão basta para dissipar esse semblante de contradição. O começo, o princípio ou o absoluto - como de início se enuncia imediatamente - são apenas o universal. ${ }^{44}$

Ora, se o verdadeiro é o Todo e o todo é só o que resulta de um processo e nele desdobra, é preciso que ele já tenha ocorrido quando algo da ordem do verdadeiro entra na pena do filósofo. É necessário, portanto, que tudo o que Hegel diga já seja passado, porque já se pode compreendê-lo como Todo. A imagem da totalidade omniabarcante que antecede o tempo vivido, espécie do desdobramento necessário de um espírito que só cumpre uma série de coisas que já tinha de cumprir, é profundamente falsa. Também

\footnotetext{
${ }^{42}$ I.e., que nunca leu o livro.

${ }^{43}$ HEGEL, 2017, p. 210.

${ }^{44}$ HEGEL, 1992, p.31.
} 
o é a imagem de que Hegel acaba com o tempo histórico ou com a possibilidade inerente à contingência. Hegel não fala de um "fim" das coisas pelo simples de fato de que elas, de fato, acabaram e as obras dos campos sobre os quais fala não existam mais; antes, o fim chega desde o ponto de vista lógico. Não importa que sequência de novidades se interponha, de um certo momento em diante passará a ser sempre a obra do Espírito a falar sobre $\mathrm{si}^{45}$. Nesse sentido, também, o contingente precisa sempre cair do conceito e, portanto, desde a perspectiva do Todo, é preciso já ter havido o desenvolvimento por completo.

Se o movimento da filosofia é justo o de traçar o conceito, ela só pode falar do que se pode conceituar. E ela só pode conceituar aquilo que já se desdobrou até o seu limite. Daí a crítica de Hegel, de início, incidir sobre uma fala que discorre livremente sobre o presente, como se o desvendasse. Se o presente pode ser situado - e daí as falas sobre o momento atual, o papel e a possibilidade de transformação da filosofia e por aí vai - ele não pode ser compreendido conceitualmente. Ele (o presente) pode ser suposto como o momento no qual a filosofia vai finalmente se realizar como ciência ${ }^{46}$, desde que tal suposição se ancore numa demonstração da formação da filosofia em direção ao seu momento de realização. Ou seja: para que Hegel possa falar no prefácio que agora é a hora e a vez da filosofia, novamente começa pelo fim, posto que a finalização da história a ser contada informa e formata a história a se contar. ${ }^{47}$

\section{Em termos práticos}

Dada a complexidade da obra que temos em mãos e dadas nossas hipóteses acerca da verificação do processo de formação no Prefácio, circunscrevemos essa área como aquela na qual nos concentramos e a partir da qual falaremos. Temos por base tanto a definição hegeliana de que o começo é o fim, agora mediado ${ }^{48}$, quanto os breves comentários de Gadamer, por nós já citados, que serão explorados nessa tese, segundo os quais Hegel teria construído o prefácio para servir de introdução tanto à

45 No capítulo dois nos debruçaremos melhor sobre esse problema, mas antecipamos que é muito menos um término da história como a conhecemos do que a adoção de outro ponto de vista frente a ela.

${ }^{46}$ HEGEL, 1992.

${ }^{47}$ Essa ideia foi longamente desenvolvida por SAFATLE, 2015.

${ }^{48}$ HEGEL, 1992. 
Fenomenologia quanto à Lógica. Ora, tais comentários parecem certeiros, uma vez que, para Hegel, a leitura só realmente se completa quando se chega ao fim do Prefácio pela segunda $\mathrm{vez}^{49}$. Importante ressaltar que a primeira leitura do Prefácio se faz com $a$ consciência sendo e se sabendo consciência; da segunda vez, com a consciência já tendo se reconciliado e, por isso, enquanto resultado de um longo processo de formação, por ela agora compreendido.

Não é incomum que muito do Prefácio pareça simplesmente apontar para algo que, à altura da primeira leitura, seja incompreensível. Hyppolite, como Gadamer, figura no grupo de autores que o situaram ao fim da obra, à diferença de que seu expediente é ainda mais radical: a análise do Prefácio é feita em conjunção com a do capítulo sobre o Saber Absoluto ${ }^{50}$. Tudo se passa, então, como se para Hyppolite fosse questão de juntar fim e começo da formação e de mostrar como esse elo é possível e até mesmo facilita (em muito) a compreensão da obra.

Essa a razão pela qual nosso primeiro capítulo tenta fornecer o terreno no qual o Prefácio pode comparecer como uma introdução ao livro tal e qual previsto por Hegel. Embora soe contraintuitivo, dado os comentadores e suas posições peculiares quanto à análise da seção que temos em mão, construímos todo um capítulo destinado a situar a obra e a ler os primeiros parágrafos da seção por nós escolhida como se uma consciência ingênua o lesse.

Já o segundo capítulo abandona essa leitura ingênua e mostra como o Prefácio aponta para o capítulo um, capítulo no qual a interdição de uma linguagem sobre o presente é feita da maneira mais incisiva. Apesar dessa interdição inicial, é sabido que no capítulo sobre o Espírito a consciência a linguagem como se nada tivesse se passado. O que nos interessará aqui, no entanto, é a série de consequências dessa interdição presente no primeiro capítulo e a maneira pela qual isso expressa uma certa forma de uso linguístico de Hegel que já pressupõe o especulativo, ou seja, Hegel interdita a linguagem sobre o presente de maneira a formar a consciência para o uso da linguagem especulativa.

${ }^{49} \mathrm{O}$ interesse de Gadamer pela temática do círculo é um tanto quanto fácil de apreender. Também a hermenêutica trabalha desde esse ponto de vista, a diferença sendo que a hermenêutica se permite ser um círculo virtuoso, ao passo que o círculo hegeliano se fecha e se completa finalmente.

${ }^{50}$ Cf. a esse respeito, HYPPOLITE, 1979. 
Uma tal dimensão formativa se expressará de maneira mais clara na diferenciação efetuada por Hegel entre proposições especulativas e proposições raciocinantes, o que exige uma remissão ao capítulo sobre o Espírito e outra remissão ao capítulo sobre o Saber Absoluto. Isso porque é nesses capítulos que aparecem de maneira explícita uma caracterização das consequências de cada uma das proposições.

Nossa estrutura de tese, como deve ser tornado claro aqui, visa demonstrar como a formação hegeliana se dá muito mais a partir da demonstração experenciada de que algo vai de um ponto a outro e tem certas consequências do que a partir de uma argumentação clássica em filosofia. Dito de outro modo, formar para Hegel tem o caráter de experiência ${ }^{51}$ muito mais do que um caráter abstrato ou distanciado, de conteúdos que são simplesmente assimilados como alteridades. Isso porque experimentar alguma coisa é, primeiro e antes de tudo, se colocar numa situação. A recaptura de si se faz absolutamente necessária, posto que é inescapável que seja aquela consciência que está experimentando que esteja em jogo. Dito de outro modo, ninguém pode ter minha experiência em meu lugar o que torna minha apreensão daquela coisa minha e não a apreensão de algo completamente estrangeiro a mim, que estranho ou ignoro. Tendo uma impressão daquele objeto, ele como que se torna meu objeto, pois não é possível me referir a ele sem que seja eu quem me refira ${ }^{52}$.

Em segundo lugar, dadas as ressonâncias de Erfahrung - o termo alemão para experiência -, temos que esse modo de se pôr em jogo acontece de modo que quem se coloca arrisca mesmo seu aniquilamento e o consequente aniquilamento de seu mundo, razão pela qual a dialética é tida como o caminho do desespero. Desfazendo os pressupostos seguros que o indivíduo inicia, a dialética faz o mundo inicialmente compreendido de um certo modo colapsar ${ }^{53}$. tendo isso, por seu turno, permite a assimilação, posto que a aniquilação possível de si não ocorre senão parcialmente, a

${ }^{51}$ Não subscrevemos à leitura famosa feita por Heidegger do conceito hegeliano de experiência. As razões para isso são amplamente discutidas - e por nós acatadas - num texto de XIAOMANG, 2009, que constará na bibliografia. Em resumo, Heidegger parece não se preocupar muito com a diferença de concepção de ontologia existente entre ele mesmo e Hegel que tinha uma lógica dialética como fundamento do real (se ontológico ou puramente lógico, a discussão é longa).

${ }^{52} \mathrm{O}$ que a introdução da Fenomenologia tenta demonstrar na sua crítica a Kant e na relação do em si com o para si.

${ }^{53} \mathrm{Ou}$, em hegelianes, explicita o para-si necessário e inerente ao em-si. 
intromissão do conteúdo incômodo servindo de propulsão à reconfiguração subjetiva da consciência leitora.

Assim, por exemplo, se formação é também o caminho de preparação para a Lógica, é preciso que Hegel já introduza as proposições especulativas ao sistematizar as experiências de formação. Dito de outro modo, ao sistematizar a formação do jeito que faz, Hegel já nos está formando. Essa a razão de escolhermos uma parte que é necessariamente reduplicada: isso nos evita a necessidade de uma leitura da Fenomenologia que percorreria todos os pontos - o que seria fútil para o que estamos propondo - e reforça nosso ponto, segundo o qual só há possibilidade real de formação em Hegel se o prefácio puder ser o todo antecipado do qual fala ao fim do livro.

Isso porque ao terminar a obra, o leitor deve ser capaz de compreender o porquê de ter lido sobre sua formação, a maneira pela qual essa leitura introduz a dialética e, também, a clivagem supracitada. Ao ler o Prefácio, seção que agora está justificada pelo desenvolvimento até ali e, especialmente, pela seção do Saber Absoluto, a consciência averigua que sua formação se concluiu. Os termos não mais parecem abstrações sem sentido ou frases de impossível compreensão. Também não parecem falar no registro contingente, embora as palavras ali empregadas apelem para esse duplo sentido muitas vezes. Deve ser capaz, portanto, de entender o porquê de só poder falar do efetivo que já passou e deve entender, também, que tudo o que aprendeu ali tem sua dependência lógica alhures, embora precise ser cronologicamente introduzido primeiro. ${ }^{54}$ Começar pelo fim, nosso título, adquire um segundo sentido: a Fenomenologia só pode começar lá mesmo onde Espírito já se esgotou e já se compreendeu.

Duas notas, antes de começarmos: essa tese faz parte de um esforço de atualização da filosofia hegeliana e, portanto, é uma tese que busca trazer uma visada sobre o que há de possível e atual em Hegel. Foi esse o mesmo trabalho empreendido por Kojève ${ }^{55}$, à sua época, mas também é o mesmo esforço que vemos em Marcos

${ }^{54} \mathrm{O}$ que Hegel pontua afirmando que "a ciência só aparece ao fim do processo: a ciência não se manifesta no tempo e na efetividade antes que o espírito tenha chegado a essa consciência sobre si mesmo". HEGEL, 2000, p.214.

55 KOJÈVE, 1947. 
Nobre ao pensar o novo em Hegel ${ }^{56}$, Catharine Malabou ao pensar o futuro de $\mathrm{Hegel}^{57}$, Zizek ao longo de sua obra, mas especialmente ao pensar o marxismo a partir de Hegel, Marloren Miranda ao propor tanto uma nova figura do espírito ${ }^{58}$, quanto uma leitura da forma da escrita hegeliana pelo conceito de "narrativa especulativa" 59 e, por fim, os esforços de Buck-Morss em tentar ligar Hegel e a revolução do Haiti ${ }^{60}$. Todos esses esforços se centram na ideia de que a filosofia Hegel pode ser sempre atual inclusive contra aquilo que o indivíduo Hegel representou.

Por último, não nos parecia fazer sentido seguir essa tese exclusivamente com autores cujo o campo se restringiam ao "progressismo" ou à "novidade" em Hegel. Se estamos pensando o presente como formado por um passado, pareceu-nos caso de constituir nossa tese como um choque entre o passado e o presente das interpretações hegelianas, ao menos se pensarmos essas duas etapas como a primeira sendo uma tentativa de reconstrução de um Hegel historicamente situado e a segunda uma leitura do que Hegel diz a despeito de seu tempo. Parece-nos mais consequente com nossa tese manter essa tensão que é, afinal, o poder e o prazer da dialética.

${ }^{56}$ NOBRE, 2018.

${ }^{57}$ MALABOU, 1996.

${ }^{58}$ MIRANDA, 2018.

${ }^{59}$ Ibid, 2017.

${ }^{60}$ BUCK-MORSS, 2009. 


\section{2}

\section{O início da empreitada}

\subsection{Excurso sobre a noção de formação}

1806-07. Esses são os anos de redação da Fenomenologia Espírito. Anos conturbados na cidade de Jena, na qual Hegel residia. Sua famosa sentença, segundo à qual Napoleão seria o Espírito a cavalo, é devedora justo da invasão napoleônica, ocorrida no momento no qual ele escreveria aquela obra que conteria a frase. Até aquele momento não tendo sido autor de obra maior nenhuma - e, como dissemos, seguimos Gadamer para quem obras só o são mesmo, no fundo, a Lógica e a Fenomenologia ${ }^{61}$ , mas tendo produzido textos como Fé e Saber e o Differenzschrift, Hegel se via às voltas com um dos muitos problemas filosóficos do seu tempo e, em algum grau, um problema que é também o de qualquer um que se dedica à filosofia ${ }^{62}$ : qual o papel da filosofia, dado o tempo histórico dentro do qual nos situamos?

Se, por um lado, acreditava firmemente que a filosofia deveria fornecer as possibilidades de reparação de uma série de cisões instauradas pela modernidade (homem/mundo, sujeito/objeto, sociedade/indivíduo, etc.), por outro, parecia mesmo discordar tanto da maneira pela qual seus contemporâneos ofereciam suas soluções, bem como das próprias soluções oferecidas aos problemas ${ }^{63}$. Tal discordância não

${ }^{61}$ GADAMER, 2012, p.94.

${ }^{62}$ É sabido que em sua juventude Hegel não se diferenciava tanto assim dos românticos seus contemporâneos. Mesmo sua solução aos problemas de cisão, durante muito tempo, foi o amor. Mas, interessante que seja essa fase de Hegel, ela foge e muito ao nosso escopo. Cf. a esse respeito, a obra de Lukács sobre o jovem Hegel, LUKÁCS, 2018.

${ }^{63}$ Digno de nota, aqui, os fatos de que Schelling, o outro filósofo a propor um Absoluto, é costumeiramente dividido pelos comentadores em várias fases; Fichte não passar pelo mesmo problema, mas, grosso modo, ainda manter os problemas de cisão; Schopenhauer abertamente querer apenas reformular alguns aspectos da filosofia kantiana. Ou seja, o único outro filósofo que propôs uma noção próxima de Absoluto ficou insatisfeito com a própria solução que deu a ponto de modifica-la constantemente. Compare-se a isso o fato de Fenomenologia e Lógica terem sido obras suficientes, está última a única a ser revista posteriormente em alguns aspectos. Seus textos posteriores, sendo apenas elaborações didáticas de seu sistema, não o modificam substancialmente, apenas adicionam coisas que nunca estiveram presentes na forma de obra ao seu pensamento, mas vê-se que tudo se subscreve ao mesmo modo de pensar. Afirmativas de comentadores por nós já citadas como "A história torna real a Lógica" só pode fazer sentido se houver relação de identidade forte entre uma e outra. Para um estudo comparativo entre as ontologias de Hegel e de Schelling, cf. KUSSUMI, 2020; para comparativo entre os idealistas alemães sans Hegel (embora seja um estudo de matriz hegeliana) BEISER, 2008. 
vinha apenas da maneira pela qual Schelling e Fichte elaboraram suas noções, tampouco vinha do problema inerente à solução das cisões do mundo a partir de uma noção filosófica de amor. Em outras palavras, o problema não estava simplesmente no conteúdo filosófico apresentado pelas soluções com as quais Hegel se deparara ali. Não era apenas o assunto sobre o qual os sistemas que estudara que estava abordado de uma forma que parecia insatisfatória a ele. Antes, e talvez sobretudo, o que o incomodava sobremaneira era a noção de que os sistemas não eram capazes de englobar a realidade de maneira formal, e aqueles que o elaboravam pareciam desconhecer isso de uma forma ou outra.

Em grande parte, isso poderia decorrer do fato de os filósofos parecerem assumir, em grande parte, a logicidade própria da filosofia como inerente tanto à filosofia quanto à realidade, o que faria com que a estruturação de um sistema fosse capaz de dar conta da realidade como um todo, tal e qual ela se apresenta. Sem se dar conta, acabavam por excluir algum elemento ou outro, ou por oferecer a algum deles um papel menor no escopo das coisas ou, simplesmente, como fez Kant, assumir uma impossibilidade e aceitar a limitação do conhecimento - e Kant é criticado por Hegel por justo "começar errado", não à toa é criticado por ter "medo da verdade"64. Mesmo Schelling, com seu sistema, caíra na armadilha da exclusão de algo fundamental: a diferença. Aos olhos de Hegel, Schelling teria criado um mundo no qual "todas as vacas são pretas" ${ }^{\prime 65}$, ou seja, teria negado a diferença entre as coisas em prol da alocação de todas elas em seu sistema.

Notemos como os erros que Hegel identifica em seus antecessores ou contemporâneos não são erros no sentido simples de um equívoco na descrição adequada da realidade, mas sim em quais pressupostos eles se baseiam para descrevêla. A inadequação é anterior à execução do próprio sistema, razão pela qual a correção terá de incidir fundamentalmente em algo que permite o sistema, algo que é, portanto, o eixo sem o qual não pode funcionar.

Ora, quem fala em erro na adoção de pressupostos fala e pensa sobretudo na maneira pela qual eles foram formados e tidos como corretos. Fala, então, no processo

\footnotetext{
${ }^{64}$ HEGEL, 1992, pp. 63-64.

${ }^{65}$ HEGEL 1992, p.29.
} 
mesmo de composição de um pensamento. É preciso um longo percurso para que um pressuposto adentre uma mente humana como correto, percurso esse composto de um espírito do tempo, contato com certos pensamentos, aprendizado de uma língua...em suma, um longo processo educativo antecede toda a formação daquilo mesmo que se pode chamar de nome próprio, algo que o próprio Hegel constantemente aborda ${ }^{66}$. Um outro nome pra isso é justo formação, que no alemão guarda a peculiaridade de também fazer ressoar cultura; são dois dos sentidos de Bildung que são escutados a um só tempo 67 .

Nesse sentido, a formação precisaria advir de uma outra forma de pensar a relação que o indivíduo tem com sua própria formação. Uma carta de Hegel a Niethammer, de 1812, que versa sobre a educação, nos mostra bem a que compreensão de formação Hegel chegou ao elaborar sua Fenomenologia:

Tornou-se um preconceito, não só do estudo filosófico mas também da pedagogia - e aqui ainda mais difundido -, que o pensar por si se deve desenvolver e exercitar, primeiro no sentido de que a este respeito não depende do elemento material e, em segundo lugar, como se a aprendizagem fosse oposta ao pensar por si mesmo, pois, na realidade, o pensar pode exercitar-se apenas em semelhante material, que não é produto e composição da fantasia nem de uma intuição, chame-se ela de sensível ou intelectual, e, além disso, um pensamento não pode aprender-se de nenhum outro modo a não ser que seja pensado por si mesmo. Segundo um erro geral, parece que a um pensamento se apôs o cunho do ser pensado por si mesmo só quando ele desvia do pensamento dos outros homens. ${ }^{68}$

Além da óbvia defesa da universalidade contra a singularidade, colocada adiante por Hegel, há também um elemento que parece menor, mas que é central ao seu pensamento: não existe singularidade independente de uma formação e de uma imersão numa universalidade e, mais ainda, entre esses dois termos não existe contraposição absoluta, mas copertinencia. Assim, um filósofo só produz "seu" sistema filosófico na medida em que esse sistema é já ele produto de uma formação e, muitas das vezes, uma resposta a ela ou uma consequência dela. Isso não é apenas no sentido

${ }^{66} \mathrm{Cf}$. logo abaixo nossa referência às cartas trocadas com Niethammer.

${ }^{67}$ Sempre se pode arguir que "cultura" também tem essa dimensão, posto que um indivíduo culto é também cultivado e bem formado, a metáfora agropastoril funcionando apenas em decorrência disso. Seja. Mas em alemão não se pode dizer uma palavra sem se dizer a outra, porque são mabas uma e a mesma.

${ }^{68}$ HEGEL, 2018, p.395. 
mais leve de dizer que é preciso o básico de conhecimento de filosofia para que se possa filosofar; antes, é o mesmo que dizer que é preciso que um homem possa se compreender de um certo jeito, em um certo tempo, num certo espaço, etc. para que ele filosofe de uma certa maneira. Formação adquire, assim, um sentido muito mais complexo do que simplesmente a aquisição de conteúdos e a competência de manejo desses: formar-se é tornar-se alguém, tornar-se o homem que produzirá pensamentos, reflexões e etc. É, portanto, por ser fruto de uma determinada formação específica que seus contemporâneos ou antecessores produzirão os erros que produzem.

Isso explica porque muitas das críticas de Hegel não incidem somente sobre o conteúdo das obras de seus contemporâneos, mas também sobre as consequências ou sobre o quanto elas revelam daquele que diz. É muito mais à circunscrição contextual do seu autor e as consequências de sua de fala, àquilo que ele diz sem saber que o diz, que Hegel apela ao criticar, por exemplo, Kant, Schelling ou os românticos ${ }^{69}$. Afinal de contas, a crítica que Hegel faz a Kant não é, como já dissemos, uma crítica puramente epistemológica. Se é verdade que faz longos parágrafos sobre as construções do edifício kantiano, é igualmente verdade que o momento alto de sua crítica é acusar o cuidado de seu alvo com a verdade de ser, no fundo, um medo dela. Seria, portanto, o medo da verdade kantiano que o teria levado a uma construção excessivamente cuidadosa e a manter uma abstração - aos olhos de Hegel - como a coisa-em-si. É como se Kant não levasse a própria descoberta ao fim de sua radicalidade porque dela recuou com medo. É como se ele não estivesse à altura do próprio filosofar e isso o fizesse tremer.

Note-se aí, então, que a reflexão que Hegel faz sobre sua época vai motivar a própria reflexão que ele faz sobre a composição do sistema e, por conseguinte, a maneira pela qual ele mesmo construirá a performance de sua escrita. Por isso se, por um lado é bem verdade que é chegada a hora da filosofia ${ }^{70}$ como Hegel dirá, a reflexão sobre os porquês dessa mesma hora ter chegado quando chegou precisa ser feita para que qualquer filosofar seja possível. A filosofia, para estar à altura da sua tarefa, deve reconhecer, portanto, sua dependência com a história do mundo e deve, a partir disso,

\footnotetext{
${ }^{69}$ Como esses últimos são como que usados por Hegel em sua exposição, nos detivemos em um subcapítulo só neles.

${ }^{70}$ HEGEL, 1992.
} 
ser também a história filosófica do mundo ${ }^{71}$. Em termos de obra de Hegel, poderíamos dizer que não seria suficiente escrever apenas a Lógica; a Fenomenologia, obra cuja referência nunca foi removida das versões posteriores de sua magnum opus, era uma necessidade tão grande para a época quanto o era a Lógica. Nela estava contida uma espécie de longo resumo, posteriormente desdobrado nos cursos, da história filosófica do Espírito $^{72}$. Daí sua importância como introdução e parte integrante do sistema: ela fornece uma análise das condições de possibilidade da própria existência da filosofia tal e qual ela se configura em sua forma hegeliana. Essa mesma análise deve ser formativa, na medida exata em que é uma análise da formação.

Se, para Hegel, Schelling se equivocou em não dar a devida centralidade à história do Espírito, acertou em pelo menos uma coisa: para que a filosofia fosse capaz de emitir verdades, ela teria que ser, de fato, sistema. O problema na forma de Schelling não está exatamente no fato de que tente escrever de forma sistemática, mas na maneira que seu sistema "se estrutura" enquanto tal. A leitura imediata que fazemos da expressão que aparece anteriormente entre aspas - "se estrutura" - tem a mesma dimensão profundamente estática que conferimos a ela na obra de Schelling, ao menos para Hegel, sendo a estaticidade o maior dos problemas. Assim, "se estrutura" deveria significar algo "mais apegado à palavra" por assim dizer, ou seja, um sistema que "se estrutura" deveria literalmente ser apresentado como o processo de estruturação do sistema. Nesse sentido, caberia ao filósofo não tanto articular conceitos que fizessem uma abstração da realidade ou sua reunião no múltiplo ${ }^{73}$; antes, o filósofo deveria apresentar uma história filosófica da formação da realidade do Espírito tal e qual ela se deu e isso seria o princípio de sua filosofia, posto que articularia, num só tempo, lógica e história ${ }^{74}$.

O recurso ao passado e à sua capacidade de explicação do presente tem sua justificativa não apenas na maneira de compreender a relação entre os tempos, mas também numa necessidade intrínseca ao sistema: totalidade. Pois algo só é um sistema

${ }^{71}$ KOYRÉ, 2011 pp. 166-170.

${ }^{72}$ Como Forster, já citado, observou.

${ }^{73}$ Segundo Lebrun (2000), é a definição clássica de conceito que perdura até Kant, o que concordamos.

${ }^{74}$ Como articula Nascimento (2010), mesmo a Lógica tem uma dimensão profundamente histórica que lhe serve de base. 
na medida em que seus termos se articulam. Ademais, algo só é todo na medida em que é fechado em si mesmo, sem aberturas porosas para quaisquer coisas. Ora, um pensamento assim articulado não poderia, por isso, escolher o presente, posto ser a definição canônica deste o fato de que passa no momento em que o tentamos apreender. Em outros termos, a definição do presente é ser contingencia pura. Curiosamente, entretanto, as filosofias imediatamente anteriores ainda contavam com essa compreensão de tempo presente, mantendo uma copresença entre o discurso filosófico e a realidade. Não à toa, tiveram dois destinos, de acordo com Hegel: a dissolução das diferenças presentes do real numa totalidade indiferenciada (Schelling); ou a oposição insuperável entre indivíduo e realidade (Fichte). ${ }^{75}$ A consequência para falar do presente e de toda a negatividade que lhe é inerente foi, portanto, sua neutralização completa ou a impossibilidade de sua superação. Perde-se algo toda vez que o presente é o tempo sobre o qual se fala.

Contra ambas as opções, Hegel decide outra forma de falar do presente: aquela que fala de sua formação e não de sua atualidade. Pois ao fazer isso, recupera a possibilidade de falar do trabalho do negativo e dos desenvolvimentos ao mesmo tempo em que pode fazer um sistema que trata da totalidade ${ }^{76}$. Pode servir-se daquilo que foi a realidade efetiva para demonstrar a veiculação de sua lógica como lhe sendo imanente. Analisar a formação, portanto, por mais que faça com que a contingência caia, confere-lhe também o papel central, o que se expressa, nas palavras de Hegel como "a cada momento abstrato da ciência corresponde em geral uma figura do espírito que-se-manifesta"77.

Dito de outro modo, é apenas a partir de um tempo efetivo, da vida dos homens, que a ciência pode vir a ser ciência. Não existe uma predestinação espiritual dentro da qual os homens estão inseridos e ou bem se adequam ou perecem; antes, é na luta contra o perecimento e em direção às construções que lhes são próprias que os homens como que fazem o Espírito caminhar. Isso é o que significa a astúcia da razão: a independência que o Espírito tem das ações humanas é apenas independências das suas

\footnotetext{
${ }^{75}$ Koyré se debruça longamente sobre essas considerações de Hegel. Cf. KOYRÉ, 2011.

${ }^{76}$ Como veremos ao fim da tese, isso tem relação direta com a alteração da compreensão e da posição da noção de tempo e, por conseguinte, de desenvolvimento.

${ }^{77}$ HEGEL, 2000, p.219.
} 
intenções e desejos, ou seja, do fato de que o homem quer algo e deseja, com isso, mover a história ao seu favor. Mas é a partir desse desejar que o próprio Espírito pode agir e se tornar qualquer coisa. Do mesmo modo que os filósofos sempre revelam algo de si ou dizem mais do que gostariam de dizer quando filosofam, os homens sempre agem com consequências para além do que podem prever. Sendo assim, a transformação em efetividade, ou seja, elevar do material concreto ao lógico é central no desenrolar da história do espírito.

É por isso que ao fim e ao cabo, a ideia de formação pressupõe exatamente os processos a partir dos quais algo se torna o que é. Demonstrar como algo adveio é, também, falar sobre tudo aquilo que esse algo é e sem o qual não tem existência ou, trocando em miúdos, sem passado não há presente. Mais do que isso, inclusive: é falar sobre as condições de possibilidade efetiva desse algo, ou seja, sobre quase que como seu transcendental, embora um tipo estranho de transcendental, posto ser histórico. Isso posto, qualquer texto já vai ser, ele mesmo, uma resposta a esse tempo histórico, não por gosto, mas por uma necessidade intrínseca à formação pela qual passou. Todo texto pode ser, então, mais do que seu contexto no sentido de motivá-lo a mudar, mas será sempre dependente dele. Todo texto filosófico, quer seja reflexivo e tenha essa intenção, quer não, será sempre um diagnóstico de época.

Assim pensado, o papel da filosofia não seria apenas aclarar as noções ou fornecer um olhar privilegiado por sobre o mundo; antes, seria ser capaz de olhar o próprio olho, não deixando quaisquer pontos cegos, nem mesmo aquele do observador. Hegel erige a reflexão sobre si, a capacidade de autoconsciência, como princípio fundamental de sua filosofia - mas também como conquista, não como algo dado. Será apenas ao fim do livro que um tal processo poderá ser pensado como plenamente conquistado e atingido e isso porque o fim levará, novamente ao começo, o fim da formação demonstrando que o começar não era gratuito. Por isso, se o começo do processo hegeliano é por um prefácio que adianta um todo carente de conceito (Fenomenologia) ou pelo puro ser (Lógica), pouco importa aqui nesse sentido específico $^{78}$; no fim, o começo deve estar plenamente justificado pelos desenvolvimentos ulteriores.

${ }^{78}$ GADAMER, 2012, p.44. 
Isso implica que o pressuposto ou a proposição fundamental, para ser assim nomeado, tem de possuir a capacidade de se desenvolver e, em seu desenvolvimento justificar sua pertinência. Ou será que implica? Quando pensamos desenvolvimento, tendemos a pensar em atualização de potência, ou seja, tendemos a pensar sobre o fato de que algo pode vir a ser e, portanto, se torna um possível dentre muitos. A ideia de Hegel nos parece radicalmente diferente quando pensa desenvolvimento. Num primeiro momento, existe uma série de possíveis que podem se atualizar e existe a situação existente; algo perturbar essa pacífica unidade e introduz aí um impossível, que só é assim compreendido porque aquela formação dentro da qual esse algo se instaurou não fornece as condições de possibilidade de sua absorção ou compreensão; dado que esse impossível precisa ser resolvido, cria-se uma nova situação a partir dele, o que o torna agora algo em ato e, também, algo a partir do qual as pressuposições vão se $\operatorname{dar}^{79}$.

Isso obviamente gera uma dificuldade ainda maior para análise filosófica de uma formação. Se tratasse de condições de possibilidade, apenas, Hegel teria um problema bastante denso em mãos; mas como quer tratar delas expondo como o negativo, enquanto impossível, move o mundo, Hegel gera um problema ainda maior. Mas cremos que isso, antes de ser um problema, é a solução para eles.

Quando era de condições de possibilidade que se tratava, ou seja, atualizações de possíveis, Hegel tinha pelo menos duas opções para a filosofia se realizar enquanto sistema, ambas igualmente incapazes de perfazer, por si só, todo o sistema: uma, relativa à história filosófica, que precisaria demonstrar o desabrochar de acontecimentos um de dentro de outro, i.e., uma sucessão de superações históricas nas quais um momento dá origem a outro. Nesse sentido, então, a história seria um jogo de desenrolar de potências e atos, o próximo possível se atualizando depois do anterior em uma sucessão não necessariamente progressiva (no sentido de melhoria). Essa possibilidade tem por problema o fato de que só pode versar sobre o presente falando de seu passado, razão pela qual será sempre lida numa relação dialética com ele: por um lado, apenas existe porque o mesmo presente existe; por outro, será outra coisa

\footnotetext{
${ }^{79}$ Essa estrutura será amplamente explorada no capítulo dois, quando nos debruçarmos sobre a linguagem e o capítulo sobre a certeza sensível.
} 
além desse presente em sua atualidade, posto ser sua história (será seu negativo, afinal). Além disso, os problemas em relação ao projeto são bastante evidentes: o discurso não se realiza ao mesmo tempo do acontecimento, mas o espera terminar e gerar todos os ecos que pode antes de falar sobre ele. Recorre em passadismo. Seria, assim, uma imersão na concreção, uma história sempre aberta e provisória, duas noções bastante contraditórias à de sistema, vez que este deve perfazer a totalidade e aquela pressupõe uma abertura.

Outra possibilidade seria uma lógica de maneira exclusiva, esta última versando apenas acerca de si mesma, sendo com isso o processo do pensamento pensando a si mesmo e apenas a si mesmo. Por ter por finalidade mostrar para o leitor que existe uma relação de identidade entre a estrutura de seu pensamento, o ato de pensar e o próprio livro, essa poderia falar no de um plano lógico copresente ao discurso filosófico, porque tomaria este como o presente real, a saber, a eternidade ${ }^{80}$. Essa é a exata condição para que a Lógica possa falar do presente: que ela não seja mais o discurso sobre o tempo, apenas discurso sobre o pensamento pensando a si mesmo. A perda a que essa opção deveria se submeter seria a de deixar de fora a própria materialidade, ou seja, a capacidade crítica em relação aos aspectos de sua própria formação. Seria possível falar de e sobre o próprio pensar, mas não seria possível fazer o percurso que levou o pensar até essa altura. Obviamente, o problema em relação ao objetivo, aqui, é distinto: para a consecução do objetivo, é preciso contar com um "tempo eterno" como o único tempo possível e preciso abrir mão completamente da contingência histórica ou, em bom hegelianes, seria preciso abrir mão do voo da coruja de minerva. Isso foi algo que não deixou de ser percebido e enfatizado por Hegel quando da redação de sua obra ${ }^{81}$ e a execução da Fenomenologia é a resposta de Hegel a isso.

Apesar da afinidade com a última solução e de sua adoção e realização na Lógica, a dificuldade da temática levava Hegel a notar que uma obra como esta precisaria de uma introdução que fizesse com que a consciência saísse de sua imersão na vivência hodierna e na contingência e fosse capaz de pensar sua formação para o pensamento e, partir disso, o fato de que a autoconsciência o é também do real.

\footnotetext{
${ }^{80}$ KOYRÉ, 2011, pp.158-160.

${ }^{81}$ HEGEL, 2016, especialmente todo o desenvolvimento do prefácio da referida obra (Ciência
} da Lógica) 
Precisaria, em suma, da primeira obra que lhe serviria de introdução, mas que teria a Lógica em seus pressupostos, na sua execução e em sua estrutura. Hegel formula, em resposta a isso, sua Fenomenologia, articulando, ao mesmo tempo, suas concepções de história e lógica, de modo que na introdução já se esteja na lógica inerente à Opus Magnum do sistema, vez que nele já entrou. Caberá à Lógica "apenas" demonstrar o processo de pensamento envolvido na articulação efetuada na Fenomenologia ${ }^{82}$. A Fenomenologia se torna lógica e a Lógica uma apresentação fenomenológica ${ }^{83}$.

Quando a junção de lógica e história ocorre o movimento, por seu turno, se modifica: não será questão mais de uma história que se desenvolve a partir de possíveis, nem de uma educação da consciência a partir da atualização de suas possibilidades; antes, será caso de pensar como a história é uma sucessão de impossibilidades que perturbam um campo já estabelecido e o tornam instável, fazendo com que, para que ele seja englobado, a situação saia de um momento de estabilidade "A" para outro, "B”, onde os pressupostos farão do impossível, base. Dito de outro modo, algo que era impossível de compreensão e existência mobiliza o contexto específico e o torna instável; a instabilidade faz com que a situação precise se alterar para englobar aquilo com o que antes não contava; ao ser englobado, esse impossível redefine os termos de compreensão e se torna não apenas possível, como formador. Esse movimento, que tende a ser erroneamente descrito como tese, antítese e síntese (veremos o porquê de ser errôneo adiante), é aquele próprio da lógica de Hegel e é o eixo de compreensão a partir do qual ele escreverá sua Fenomenologia. Ao articular logicamente as ocorrências da contingência, a consciência ganharia assim capacidade de abandoná-la enquanto concreção exterior e poderia reconhecer a si mesma como formada, o que significa se reconhecer, também, na realidade que crê apenas objetiva.

Com tudo o que dissemos até aqui, não é de espantar que Hegel tenha escolhido produzir, na sua obra de introdução ao seu Sistema, uma ruptura dupla com os autores de seu tempo que tinham preocupações semelhantes. Hegel rompe, por um lado, com o que poderíamos chamar de forma prévia do Sistema, indicando tanto sua lógica de articulação quanto sua estrutura escrita, posto que ambas estariam numa relação de

\footnotetext{
${ }^{82}$ GADAMER, 2012.

${ }^{83}$ KOYRÉ, 2011, p.228.
} 
mutua dependência. Hegel faz isso ao propor um sistema que se desenvolve e, gradualmente, se sistematiza no decorrer da escrita/leitura realizada. Por outro lado, rompe com a própria noção do que significa verdade, posto que só haverá verdade no desenvolvimento e na totalidade ao mesmo tempo ${ }^{84}$. Em outros termos, Hegel rompeu tanto com o caminho quanto com o aspecto formal escolhido ao fazer com que verdade e caminho fossem termos inseparáveis ${ }^{85}$. Assim sendo, a maneira que escolheu para escrever seu sistema, a forma de fazer comparecer um encadeamento proposicional e mesmo o significado de uma proposição foram substancialmente alterados no momento em que Hegel fez adentrar o que chamou de "proposição especulativa" e compôs seu livro a partir delas. Examinaremos mais a frente, quando elas comparecerem no Prefácio, o que elas são. Por agora, apenas adiantamos que elas introduzem um elemento diferencial na formação de uma proposição, tornando impossível a consideração de que um conceito é basicamente uma descrição ou compreensão racional e adequada de um objeto. A noção de correspondência é aniquilada e em seu lugar emerge uma outra coisa, dependente do caminho para a chegada à proposição especulativa.

É o que o título do livro, de chofre, já deixa claro, aliás. Hegel escolheu dois termos bastante singulares para compor o título do seu livro: Phäenomenologie e Geistes. Para o primeiro termo, temos duas versões de explicações oriundas de três comentadores distintos. Elas nos parecem complementares. A primeira vem de Hyppolite e Forster, cada qual em seu livro dedicado à Fenomenologia. Para eles termo surge de uma modificação sutil do sentido de um termo utilizado por Lambert para construir sua óptica. Ali, em termos de verdade, estava preconizado que "a apresentação de uma não-verdade é já uma superação do erro. Conhecer seu erro é conhecer uma outra verdade. O erro percebido supõe uma nova verdade." ${ }^{86}$ É precisamente uma das possibilidades de compreensão do regime de verdade instaurado por Hegel, pois é justo fazendo com que a consciência erre (incorreção, mas não

\footnotetext{
${ }^{84}$ Daí que o verdadeiro seja definido como o todo e todo, por seu turno, como a essência que se implementa: tanto o movimento quanto seu fim são igualmente importantes.

${ }^{85}$ ZIZEK, 2014, p. 102.

${ }^{86}$ HYPPOLITE, 1999, p.30 Hyppolite menciona brevemente o livro de Kant, Princípios metafísicos da ciência da natureza, em uma nota de rodapé, mas apenas nos direciona a ele. Nada diz além disso nem aprofunda nada.
} 
errância) que ele a faz descobrir uma nova possibilidade, uma nova estrutura discursiva, uma nova possiblidade, enfim.

Mas isso não é tudo, razão pela qual a segunda hipótese, de Pinkard, nos parece igualmente luminosa. Segundo ele, o nome Fenomenologia é tirado diretamente de Kant, mais especificamente daquele momento de sua metafísica da natureza na qual ele diz que sua "investigação transcendental dos pressupostos a priori da física deveria se chamar fenomenologia" e, uma tal ciência teria objetivo não tanto de transformar "o que parece (Schein) em verdade, mas o próprio aparecer (Erscheinnung) em experiência (Erfahrung) ${ }^{\natural 87}$. Temos aqui de fato um segundo movimento necessário à compreensão do modo de operar da dialética hegeliana, a saber, o fato de que ela precisa, necessariamente, desestabilizar o certo, preencher de negatividade aquilo que parecia estável e introduzir um elemento de falha lá mesmo onde aquilo parecia assegurado para que se possa chegar a um novo estado de verdade. Como na observação de uma refração, a ilusão a ser desfeita não está no fim do processo, mas no começo dele e, portanto, é o erro do começo que a formação deve corrigir. Isso só é possível na Fenomenologia a partir da experiência, posto que é justo ela esse momento no qual o sujeito se dirige a algo ao mesmo tempo em que se coloca em risco de se colocar na posição de sofrer algo, polissemia que o Erfahren guarda dentro de si e da qual Hegel se utiliza. ${ }^{88}$

Juntas, essas possibilidades de origem do título da obra apontam para uma tentativa de, já no título, deixar bem claro o método a ser adotado: identificar um pressuposto tido por verdadeiro; demonstrar sua incorreção e mobilizar a negatividade que lhe é inerente; conquistar um outro terreno de verdade que, ao fim e ao cabo, descendia desse pressuposto.

Note-se aí que não é apenas que o "primeiro momento" fosse, em si mesmo, falso. É muito mais que ele, quando exposto, se mostre sua própria contradição, sua “antítese" pra usar um dos termos da tríade de compreensão (tese, antítese, síntese) que ficou famosa nos estudos sobre Hegel apesar de sua incorreção. Nesse sentido, $a$

${ }^{87}$ PINKARD, 2007, p.204.

${ }_{88}$ Aliás, segundo Inwood (2013), Hegel foi um dos autores que mais se aproveitou da polissemia do alemão sendo, por vezes, considerado um dos que mais expandiram o vocabulário filosófico da língua. 
antítese descende da e está contida na tese, mas não de maneira substancial como se ela estivesse lá esperando que a notassem, nem de maneira complementar, como o princípio taoísta do yin/yang (i.e., o calor pressupõe o frio, ambos sintetizados na noção de temperatura). A “tese" é algo que, se não exposta a antítese dela derivada, tem seu valor de verdade em si mesma, mas é uma verdade que não pode se realizar. Não existe "erro" no sentido absoluto que esse termo geralmente possui, i.e apreensão completamente incorreta do objeto, dentro da filosofia hegeliana. Sendo assim, o autor precisa manter o valor de verdade de todos os momentos. É por isso que é apenas durante a própria exposição dialética que se nota que a antítese está contida na tese e que a tese era apenas um momento inicial do processo, esta última uma palavra fundamental para se compreender o que é dialética. Em suma, o processo é o processo da verdade ou, se se preferir, a verdade da formação é a formação para a verdade. Nos deteremos por muitas páginas nesse tema, mas salientamos que ele já se encontra presente no próprio primeiro termo do título da obra, razão pela qual achamos por bem expor o peso que esse título carrega.

Resta ainda a questão sobre o segundo termo, Espírito (Geist). Em termos gerais, é ele quem apresenta o que estará sendo exposto no livro ${ }^{89}$. Se é bem verdade que quando lemos a obra vemos o para nós e a consciência como os dois grandes momentos distintos de conhecimento que estão nela contidos e são por ela referidos, algo como os dois grandes personagens da história, é igualmente verdade que nem um nem outro está sendo exposto, mas sim o processo de formação do Espírito humano em sua lógica e em sua história, ou seja, o que está em exposição é a história do Espírito pelo Espírito. Não à toa, ele é uma figura que surge ao fim do capítulo cinco como consequência do itinerário até ali e, desde ali, a dimensão histórica comparece de maneira (mais) direta ${ }^{90}$. Os "personagens", nesse sentido, são como que "dispositivos narrativos" para Hegel expor à consciência seu método. Leitores, quando estão iniciando no sistema "deveriam" ocupar o lugar da consciência e nesse ponto se situar;

${ }^{89}$ HEGEL, 1992, p. 25, mas virtualmente todo o Prefácio toca nesse ponto em algum momento.

${ }^{90}$ Basta ver que a passagem se efetua, inclusive, na mudança de figura da consciência. Ela agora está apta a compreender a totalidade de sua formação porque não compreende mais a "realidade objetiva" como algo absolutamente distinto de si. Mas ainda claudica nessa mesma compreensão, razão pela qual figuras de cisão como consciência honesta e dilacerada ou lei da razão e do coração estarão presentes. Será apenas no capítulo sobre o Saber Absoluto que a reconciliação estará completa. 
releituras subsequentes serão sempre feitas desde o ponto de vista do para nós, posto que já compreendem a história e o processo dialético que é o seu desenvolvimento. Dito de outra maneira, o que ocorre é que o para nós "já sabe" a história e a lógica que lhe é inerente, ao passo que a consciência as está aprendendo, aprendendo sua articulação. As está aprendendo a partir de sua experiência de leitura, i.e., a partir do contato com a própria linguagem ali empregada e dos deslocamentos que ela propõe.

É somente a partir da linguagem do conceito e de uma certa forma de embate com ela que se pode compreender o que, de fato, significa dialética. A Fenomenologia, nesse sentido, é exemplar, posto que é um processo de aprendizado da lógica dialética e da história do Espírito a partir da passagem pela experiência tanto linguística quanto de pensamento (indissociáveis em Hegel $^{91}$ ) da dialética. Essa experiência se dá no contato com a maneira pela qual Hegel estrutura os acontecimentos históricos e suas narrativas porque essa descrição já é, ela mesma, experiência de rememoração (Erinnerung) e não mera retomada dos acontecimentos como se um passado inerte e morto retornasse; trata-se, ao contrário, de uma rememoração ativa, enquanto processo e, portanto, capaz de deslocar a própria consciência de seu lugar de objetivação da realidade vivida. Deslocando assim o que tem por certo para um plano histórico-lógico, a consciência passa então a compreender que também o que é tem por possibilidade seu deslocamento, o que indica que ela mesma não é uma realidade substancial, mas uma realidade que se cristalizou de determinada forma por uma série de cadeias causais que desconhece.

Ciente disso, Hegel vê que as decisões tomadas sobre o que e como devem ser as coisas retomadas são, também elas, elementos de uma construção lógica de um passado. É, portanto, necessário concordar com Safatle, para quem, no contexto hegeliano, "recordar equivale a redescobrir fatos que foram arquivados na memória social. Se é verdade que, para Hegel, filosofia é recordação, vale lembrar que todo ato de rememoração é "uma reinscrição do que ocorreu a partir de pressões do presente" 92 . Não um mero inventário do já dito que apenas é posto numa linha temporal sucessiva

91 TAYLOR, 1999, pp.15-22 Também aí é possível ver a importância e o impacto em Hegel do pensamento Herder sobre a linguagem. Hegel jamais aceitou um pensamento ou uma verdade intuitiva ou indemonstrável. Não demonstrar é sinal de falsilóquio ou imperfeição.

92 SAFATLE, 2015, p. 176. 
e, grosso modo, acrítica, como se o passado fosse uma história estanque. Mas um passado que não cessa de se inscrever e, também, de não se inscrever, razão pela qual ele é sempre aberto como o "círculo de degraus" do qual falará Hegel posteriormente em suas aulas sobre filosofia da história e história mundial. A famosa flecha do tempo, aliás, aponta precisamente para o erro de compreensão do tempo: ali, não é apenas uma questão de erro de representação, ou seja, existiria uma representação melhor em outro lugar; antes, a própria ideia de que se possa representar o tempo como uma flecha já o confunde com o espaço ${ }^{93}$.

Note-se aqui o condensado de temas e questões que estão em jogo em uma obra que precisava, como toda obra, ser nomeada. Não era um simples título, mas algo que fosse capaz de dar conta da totalidade da riqueza de experiências propostas e exploradas ali. Não é à toa que para nomear esse conglomerado de sua escrita Hegel tenha tido tanta dificuldade que confundiu mesmo as gráficas que ficaram encarregadas da impressão da obra. Assim, as primeiras edições vieram "com o título de "Sistema da ciência, primeira parte: A Fenomenologia do Espírito”, com outros dois possíveis títulos entre o prefácio e a Introdução: em algumas edições “Ciências da experiência da Consciência, em outras "Ciência da Fenomenologia do Espírito". ${ }^{94}$ Como vimos, todos os títulos fazem sentido como nomeações possíveis da obra, uma vez que o objetivo dela é ensinar à consciência da modernidade a como fazer dialética a partir das experiências que ela já possui, mostrando, portanto, o erro nelas e como se pode chegar à verdade a partir do erro. Como dissemos, o que comumente chamaríamos de erro em outras formas de compreensão, em Hegel é tanto portador quanto produtor de verdade. O erro que a posição inicial encontra é muito mais uma oposição que o auxilia a demonstrar e desdobrar seus pressupostos e, sem a sua existência, não haveria sistema dialético demonstrável, posto que não haveria "tese" a partir da qual o sistema poderia ter sua demonstração iniciada. ${ }^{95}$

${ }^{93}$ KOYRÉ, 2011, pp.166-168.

${ }^{94}$ PINKARD, 2007, p.203.

${ }^{95}$ ZIZEK, 2014, p. Cf. também momentos, à frente mais explorados, como "Uma proposição fundamental, justo por ser verdadeira, já é também falsa”. HEGEL, 1992, p.33. 
Tendo feito todo esse percurso introdutório, que nos levou do passado do livro até seu título, podemos pensar agora em abri-lo e iniciar a leitura das seções que selecionamos. Estamos diante dele, afinal.

\subsection{Parágrafos iniciais}

$\mathrm{Na}$ seção anterior nos debruçamos sobre o passado da obra, sobre os múltiplos sentidos condensados no seu título e sobre a riqueza de temas por ela abordada. Tudo isso teve por função nos preparar para lidar com o prefácio, mas somente a partir de um ponto de vista, digamos, esclarecido. Isso tem uma razão interna à leitura que buscamos apresentar. Os dois primeiros parágrafos do prefácio, se se incluem na obra, o fazem apenas na medida em que está já pressuposto um certo leitor médio, leitor esse desaviado de tudo o que expusemos acima. Se é bem verdade que a obra, quando compreendida, deve nos dar a compreensão do que é um conceito e este é um tipo específico de movimento, a saber o de um "círculo que retorna sobre si, que pressupõe seu começo e que só atinge no fim" "96 de modo que o livro começa onde termina e viceversa, é igualmente verdade que esses dois parágrafos iniciais dialogam com um leitor que nada sabe da riqueza da obra de Hegel. Não temos a pretensão de ler a obra parágrafo a parágrafo, nem mesmo esta seção; mas temos como objetivo ler o prefácio de Hegel tanto esclarecendo certos pontos relativos à posição da consciência, quanto a partir dos ganhos de uma primeira leitura de sua obra. O gesto anterior, de esclarecimento da história da obra, um passo na segunda direção. Agora, será dado um passo na primeira.

Para que possamos assim caminhar e explorar os primeiros parágrafos em toda a sua riqueza e não simplesmente pulá-los, façamos um pequeno experimento de pensamento. Imaginemos um leitor, erudito ou não, mas que desconhece Hegel. Imaginemos ainda que este, curioso com a filosofia hegeliana, decida-se por começar a lê-la pelo seu começo "canônico". Ele vai buscar sobre o autor e descobre que sua primeira obra de vulto e aquela que serve como introdução ao seu sistema foi publicada em 1807 e se chama Fenomenologia do Espírito. Decide por adquiri-la. Passadas todas as partes nas quais os tradutores ou editores dizem suas palavras de exortação, da

\footnotetext{
${ }^{96}$ HEGEL, 1992, p. 215.
} 
importância da presente obra para o pensamento, etc. o leitor se confronta com as primeiras páginas escritas pelo autor na seção Prefácio ${ }^{97}$. São elas:

Numa obra filosófica, em razão de sua natureza, parece não só supérfluo, mas até inadequado e contraproducente, um prefácio esse esclarecimento preliminar do autor sobre o fim que se propõe, as circunstancias de sua obra, as relações que julga encontrar com as anteriores e atuais sobre o mesmo tema. Com efeito, não se pode considerar válido, em relação ao modo como deve ser exposta a verdade filosófica, o que não prefácio seria conveniente dizer sobre a filosofia; por exemplo, fazer um esboço histórico da tendência e do ponto de vista, do conteúdo geral e resultado da obra, um agregado de afirmações e asserções sobre o que é verdadeiro. ${ }^{98}$

Logo de início, no seu primeiro contato, o leitor por nós imaginado é confrontado, de dentro da seção Prefácio, com a descrição da função deste e com a negação de sua utilidade. À descrição e à negação assim feitas se seguem um balanço da maneira como se lê a filosofia, a saber, a partir de seus resultados em detrimento dos desenvolvimentos e, por último, o leitor ainda é brindado com uma comparação com a anatomia, na qual aparentemente se vê o desprezo de Hegel pela ciência da anatomia, especialmente quando em comparação com a filosofia pelo exato motivo de que ela não trata da totalidade. Hegel chega mesmo a afirmar que a anatomia é um conglomerado de conhecimentos que nem merece ser chamado de ciência.

Ao nosso leitor atento e curioso vem, então, uma pergunta à mente: se é assim, se é tão inútil a seção, por que escrever um Prefácio? Pois se é caso que tal forma textual não tem lugar dentro de um livro de filosofia e se o autor buscou escrever um livro de filosofia, resta claro, então, que não há qualquer cabimento em colocar no seu livro de filosofia algo que ele crê que não tem serventia em nenhum deles.

Aqui poderíamos apressadamente pensar em uma contradição com seus próprios pressupostos, i.e., um erro de Hegel quanto à adoção da seção Prefácio em sua obra. Sob essa ótica, a obra deveria ter começado da Introdução ou do primeiro capítulo, especialmente porque ali é onde começaria a "filosofia de verdade", isso

${ }^{97}$ As traduções foram alteradas conforme julguei necessário. Tais alterações serão indicadas quando ocorrerem.

${ }^{98}$ HEGEL 1992, p.21. 
segundo o próprio autor. Se é o desenvolvimento que importa, o Prefácio não precisa sequer existir. Estaríamos, nesse sentido, do lado de fora do castelo, vendo suas muralhas e tomando-as pelo que existe dentro dele $-\mathrm{e}$, diferente de quando assim estivemos com os autores anteriores, agora estaríamos cônscios disso, consideraríamos isso um erro e nada poderíamos fazer se não nos afundarmos numa confusão infinita.

No entanto, como o questionamento sobre o Prefácio engloba a própria seção na qual ele aparece, nosso leitor vê formar em sua consciência a pergunta pela necessidade deste prefácio específico ao mesmo tempo em que, curiosamente, se vê também questionando a existência de outros prefácios e, quiçá, do prefácio em geral. Porque o que é verdade para esse objeto de sua investigação no momento - o prefácio desta obra que agora tem em mãos - também é verdade para todos os outros. De fato, pensa o leitor, os prefácios costumam resumir o livro e/ou costumam fornecer algum tipo de leitura deste, especialmente quando é escrito por outra pessoa, prática mais comum nos dias de hoje. Parece mesmo uma espécie de apresentação da obra que tem uma estranha função: ser uma promessa de que ela mesma fará tanto mais sentido quanto mais a leitura da obra for bem sucedida. Sua função é sumamente negativa, posto que se interpõe entre a obra e sua conclusão, alongando o início do processo de leitura do qual ele curiosamente depende. O princípio da obra seria ele mesmo esclarecido no momento em que a obra fosse finalizada. Ora, mas se é assim, por que isso não vem ao fim da obra como um posfácio?

Responderemos isso à frente. Por ora, imaginemos que esse leitor decide deixar sua pergunta de lado e continuar sua leitura, certo de que algo explicará o porquê de tal empreitada. A inquietude acerca da necessidade de um prefácio oriunda do contato com o início de prefácio singular de Hegel, já se instaurou. Poderíamos mesmo dizer: algo que parecia seguro, tido como certo e natural se preencheu de negatividade, foi deslocado do seu lugar natural para um lugar de estranhamento, foi visto como móvel. Não é garantido. Faz parte de uma estratégia de constituição da obra, não é simplesmente "como as coisas são". Essa estratégia de estranhamento e posterior reconhecimento se repetirá constantemente em Hegel e será um dos motores da Fenomenologia. 
Imaginemos, então, qual não é a surpresa do leitor quando é logo brindado com a seguinte reflexão:

Do mesmo modo, a determinação das relações que uma obra filosófica julga ter com outras sobre o mesmo objeto, introduz um interesse estranho e obscurece o que importa ao conhecimento da verdade. Com a mesma rigidez que a opinião comum se prende à oposição entre o verdadeiro e o falso, costuma também cobrar, ante um sistema filosófico dado, uma atitude de aprovação ou de rejeição. Acha que qualquer esclarecimento a respeito do sistema só pode ser uma ou outra. Não concebe a diversidade dos sistemas filosóficos como desenvolvimento progressivo da verdade, mas só vê na diversidade a contradição. ${ }^{99}$

Ora, não obstante ao prefácio ter sido atribuída uma função confusa e de utilidade duvidosa, de dentro dele o autor passa a criticar as formas a partir das quais as obras são lidas quando são umas contrapostas às outras. Está, portanto, introduzindo críticas aos pressupostos de leitura, na seção mesma que julgou incapaz de sequer estar presente numa obra filosófica de maneira satisfatória. E mais: logo o leitor é apresentado ao famoso exemplo do desabrochar da flor a partir da negação do botão, que serve para ilustrar certa forma de pensar que introduz a contradição como a posição que marca o caminho do progresso, ou seja, marcando a negação (e, por tabela, a contradição) como o motor de um processo do desenvolvimento da verdade ${ }^{100}$.

De chofre, então, Hegel está executando uma operação complexa: introduzir uma contradição entre a existência do Prefácio e a crítica à utilidade desta seção de dentro da própria seção, deslocando-a da posição de algo assente para algo cujo lugar precisa ser, antes de tudo, pensado. Nesse sentido, a crítica ao prefácio que produz $e$ inicia um prefácio já é, ela mesma, a compreensão da utilidade da seção e a determinação (no sentido de situar, pôr em um lugar) desta seção. A seção já consegue gerar os pressupostos parciais para a sua própria compreensão, ao mesmo tempo em que esses pressupostos necessariamente a apontam para algo além dela. Se lido por si só, como um prefácio dentre outros, o prefácio hegeliano é precisamente como o definiu: um pedaço solto de uma obra que tenta ser apenas o resumo de resultados. Como ele tem um caráter dialético, tal operação não pode ser executada, vez que ele

\footnotetext{
${ }^{99}$ HEGEL, 1992, pp.21-22, grifo nosso.
}

${ }^{100} \mathrm{Id}$, ibidem. 
precisa de sua justificação interna ao sistema, precisa fazer parte dele, portanto. Nos parece por isso que, como dissemos, Gadamer e Hyppolite (especialmente o último) preferem lê-lo junto ao fim do livro, i.e., junto à parte que versa sobre o Saber Absoluto.

Assim, o prefácio deve ser lido dentro da economia da obra e, sendo assim, precisa sê-lo tanto ao começo quanto ao fim, tanto quando justificado quando enquanto não. Com isso, compreendemos como o movimento de escrita de Hegel torna seu prefácio a realização de tudo o que ele definiu para os outros prefácios com a negação determinada que adviria da crítica. Não é que deixe de ser o que é para virar outra coisa qualquer (parte de um todo que é maior do que ela, por exemplo), mas que se torne precisamente uma parte da obra que somente pode ser inteiramente compreendida se a obra inteira for bem entendida, sintetizando-a. De modo menos complexo, o Prefácio é tão mais perfeito em sua execução quanto mais, ao mesmo tempo, se aproxima e se distancia da crítica feita por Hegel: se aproxima, na medida em que pode, de fato, ser lido de maneira destacada e receber luzes; mas essa leitura, por seu turno, distancia o leitor, posto que exige dele a leitura da obra inteira.

Se, num primeiro momento, pode-se pensar que o prefácio de Hegel não sintetiza sua obra porque a integra, fazendo parte, portanto, do caminho da obra - i.e. "Hegel integra até mesmo o prefácio na obra", poderíamos dizer - é apenas porque se esquece que é de dentro do prefácio e compondo-o que a crítica surge. A escolha não é ocasional e não é, também, um mero deslocamento de síntese à parte (Hegel poderia ter feito um posfácio, afinal). É, antes de tudo, uma escolha por uma forma muito precisa de localizar sua posição, forma essa que só pode ser sintética na medida em que fosse, ao mesmo tempo, começo e fim. O Prefácio apresenta, de fato, todos os resultados como os outros prefácios criticados, mas não o faz da mesma forma que os outros porque só o faz lá mesmo onde as experiências já se deram. Dito de outro modo, o faz de forma a não cristalizar ou ressaltar os resultados em detrimento do desenvolvimento; antes, prefere impulsionar a concluir o desenvolvimento, tendo sentidos profundamente distintos para leitores que o possuem e para os que não.

Temos, com isso, para o Prefácio, duas inscrições de sentido que são contraditórias, posto que ele é e não é, ao mesmo tempo, tudo aquilo que Hegel atribui à seção. O prefácio de Hegel é, nesse sentido, uma seção que já se apresenta como a 
identidade da identidade e da não identidade, posto que ele só se permite compreender a partir do grau de não identidade que ele tem consigo mesmo. As duas leituras possíveis, a até aqui postulada, feita por um leitor leigo, e a nossa, pós leitura da obra, estão numa relação dialética. A primeira leitura do Prefácio fornece ao leitor a possibilidade de se opor àquela leitura corrente, pressuposta e criticada pelo autor no prefácio e já é o que se chamaria de "antítese"101; de dentro dessa, ao fim da obra e quando da releitura do prefácio, essa mesma "antítese" é suprassumida, sendo retomando aspectos iniciais e, também, parte dos iniciais que ficaram em segundo plano. A suprassunção, nesse percurso, se completa, de modo que a "antítese" se vê radicalizada é e de dentro dela e a partir do percurso que ela pavimenta que se pode ler a obra toda e o Prefácio em particular como sendo e não sendo uma forma de organização da obra. Se for a primeira leitura da consciência leitora, não, posto que ainda não passou pelas experiências de formação pressupostas e necessárias; se for a segunda experiência de leitura, pós a leitura da obra, sim, posto que entende a fluidez pressuposta e não pode se permitir fixar uma definição específica e cristalizada de prefácio, coisa exata que o prefácio não faz.

Isso é visível em mais de um momento. O segundo parágrafo, aquele que versa sobre a contradição como motor, pode ser lido como a explicitação ou desenvolvimento do gesto contido no primeiro, como se o gesto estivesse sendo desdobrado em uma explicitação racional do que acabou de ocorrer. Desde esse ponto em diante, já fica implícito pro nosso leitor médio que será a partir da contradição, pensada agora como motor do desenvolvimento, que a obra será levada adiante. Mais do que isso, fica igualmente implícito que é somente com uma contradição que a obra poderia começar pois sem ela não haveria desenvolvimento e resposta aos próprios pressupostos que seriam posteriormente explicitados. Se dirigir às seções já estabelecidas e à maneira vigente de ler as outras obras de maneira negativa é também uma maneira de introduzir a maneira pela qual algo pode ser concebido em Hegel. Como posteriormente analisaremos de maneira detida, a obra já se inicia em uma negação determinada, ou seja, em uma negação que vai necessariamente em direção a dar luz à outra coisa

101 Veremos, no capítulo três, o porquê desses termos nem sequer servirem como dispositivos didáticos, dado seu grau de erro. 
específica que surge a partir dela. Afinal, não é ao abandono completo da oposição entre autor anterior e o posterior que o livro se encaminha; antes, na colocação desses autores em um movimento de geração de um a outro. Nega-se a oposição da refutação e, com isso, se chega na oposição por seriação e desenvolvimento. Ser hegeliano, aqui, é assumir que foi necessário que tal oposição inicial se estabelecesse para que aquela que é a de Hegel sequer pudesse surgir.

Apesar da hipótese acima ser apenas uma hipótese com sentido - e não algo definitivo e provado - temos como certo que para nosso leitor imaginado algumas coisas se impuseram. Desde o prefácio, nos dois parágrafos que aparentam ser apenas uma crítica inocente e, por serem iniciais, os parágrafos menos teoricamente densos de toda a obra, já definimos algumas coisas. Já sabemos que não se trata de mais uma leitura que busca tematizar de maneira distante e não implicada alguns objetos. Fica claro que o que Hegel está fazendo não é mostrar ao leitor como ele pode captar com sua capacidade representativa toda a "realidade objetiva", ou seja, aquilo que não é ele, apenas seu objeto de conhecimento; diferente disso, aqui se trata de uma explicitação da experiência que já sempre se tem com o próprio negativo.

Diferente de dar um vocabulário novo ao leitor Hegel busca, desde as primeiras linhas, mostrar como o leitor já faz uma experiência com o negativo e precisa apenas de uma orientação da direção correta para nota-lo. Sendo assim, o começo quanto o fim da obra expõe "nada é sabido que não esteja na experiência"102. Não caberia, então, uma inovação terminológica, um acréscimo de noções; antes, o importante é demonstrar pela linguagem como certas coisas já circulam na vida do leitor sem que ele se dê conta. É, nesse sentido, um procedimento crítico, que desloca as coisas de sua posição de asserção imediata para outra posição, aquela que elas já ocupam na realidade, mas que permanece, grosso modo, imperceptível ao leitor prisioneiro do entendimento.

Em suma, nas poucas linhas iniciais já percorridas, esse estranho autor começou por criticar a utilidade de um prefácio, expôs certa atitude da opinião comum frente às obras filosóficas e começou a se contrapor a ela. Introduziu, na sua crítica, um pressuposto de leitura segundo o qual uma obra filosófica pode ser o desenvolvimento

${ }^{102}$ HEGEL, 2000, p.215. 
das anteriores e não tanto uma contradição que as anule apresentando, ainda que indiretamente, o modo que deseja que sua obra seja comparada com as outras. Se, num primeiro, momento o criticou, a cada vez que segue passa a realizar performaticamente o próprio Prefácio, ainda que de outra forma. O leitor se pergunta, agora de outro modo: por que escrever um Prefácio tão estranho?

Para além da já tradicional resposta de que Hegel não queria que nada ficasse de fora do seu sistema - o que não explica os prefácios relativamente comuns da Lógica e da Enciclopédia, por exemplo - aventamos que é porque, aqui, Hegel já está realizando uma passagem do efetivo ao lógico. Ao expor a utilidade e ao transformar, com isso, o prefácio numa seção que é reflexiva e capaz de antecipar e resumir pressupostos de sua obra ao mesmo tempo, Hegel a situa dentro de sua filosofia ou, o que seria mais correto, a situa dentro da maneira pela qual sua filosofia deveria ser lida: não mais uma filosofia com a resposta definitiva e a doutrina correta, mas um ponto de vista a partir do qual os pontos de vista se mostram enquanto momentos históricos, deslocados de sua pretensão à verdade universal ou, em uma palavra, o que Hegel definiu posteriormente duas vezes: na mesma obra como saber absoluto e, na Lógica, como puro saber.

Daí que mesmo o prefácio seja descolado de sua função imediata e tenha a função de refletir sobre o que é o prefácio: trata-se, muito antes, para Hegel, de expor as regras do jogo do que de criar um jogo novo com outras peças e regras. ${ }^{103}$ Mais um passo: trata-se, sobretudo, de historicizar o que não se sabe histórico. Que um prefácio resuma uma obra é modificação estrutural recente na confecção das obras; que um sistema precise necessariamente refutar o anterior, sem com ele coexistir, é um posicionamento igualmente histórico. Bastaria, para demonstrar isso, nos lembrarmos das várias escolas helênicas que conviveram ou mesmo da convivência dos sofistas entre si. Se sobre isso pensássemos, nos daríamos conta do quão histórico o que pensamos sobre a sobreposição de sistemas é. Esse, um dos pontos de Hegel que, ao fazê-lo, introduz também o seu: não apenas definir que os sistemas podem conviver, mas também que um é um desenvolvimento ulterior do outro. Não há hierarquia aqui; antes, encadeamento e necessidades lógico-históricas de cada sistema.

${ }^{103}$ LEBRUN, 2000, p.350. 
Além desse aspecto, uma posição educativa em relação aos leitores de seu tempo, está em jogo. A realização desse prefácio estranho em Hegel também já é o primeiro passo do autor frente às exigências da sua estratégia pedagógica ${ }^{104}$ e da introdução do leitor ao seu sistema. Sendo assim, mesmo um prefácio, quando realizado, já deve existir de um modo tal que não possa nunca ser pensado como uma exterioridade ao sistema. A compreensão deste prefácio e de sua função depende, de todo, da passagem pelo mesmo percurso que Hegel havia feito, i.e., a chegada até o fim e o retorno ao começo, onde esse mesmo começo ganhará o sentido que já tinha, mas não era passível de ser sabido. Mas igualmente depende do momento contingente da leitura da obra sem ainda saber o seu fim, posto que é nesse atrito entre o sabido previamente e o narrado por Hegel que a dialética é aprendida. Em outros termos, é no choque entre o que o leitor assume por correto e o que ele apreende do livro que a dialetização de seu pensamento ocorre.

Existe aí ainda uma forma de deslegitimar o pressuposto criticado a partir do seu próprio desenvolvimento. A noção "anterior" de prefácio entra em colapso no momento mesmo em que se expõe o gap existente entre o que ele deveria alcançar e o que ele de fato consegue fazer, ou seja, a realização de um prefácio esbarra com algo cuja sua definição deveria ser capaz de dar conta, mas não é. Há uma disjunção entre definição e realização dessa mesma definição. Outro modo de dizer isso é afirmar que existe um impossível dentro das definições, impossível esse que precipita a seção numa outra direção. É assim que o Prefácio hegeliano passa a integrar seu sistema, pois é assim que ele desdobra e faz desabar dialeticamente, ao mesmo tempo em que conserva, o que viria a ser essa parte do livro.

Parece-nos, então, que desde a abertura de sua primeira obra Hegel buscou demonstrar o que significaria percorrer com ele o caminho do conceito tal e qual ele o definia. Mais do que uma simples apreensão do objeto, o conceito seria sobretudo processo e não tanto a identidade fixa ou a correspondência entre sentença/proposição proferida e realidade objetiva. Esse caminho não viria sem as contradições inerentes ao próprio modo de filosofar do autor que, com isso, buscaria demonstrar que essas

${ }^{104}$ Cf. FORSTER, 1998. É uma das partes gerais de sua tese que Hegel, em sua Fenomenologia tem um caráter pedagógico, daí a citação da obra como um todo. 
contradições estão na realidade tal e qual a concebemos e não apenas no pensamento. Demonstrar isso exigiria uma ênfase no desenvolvimento e não tanto na capacidade de construção de determinações fixas e estáveis que, como veremos no capítulo três o autor identifica com o entendimento.

O entendimento é incapaz de ter em conta tanto a importância da finitude das coisas - dando preferência, quando chocado com a finitude, à permanência delas ainda que por cinismo ${ }^{105}$ - quanto a importância de seu desenvolvimento. Em suma, o que o entendimento trata de extrair das coisas, para Hegel, é sua determinação temporal ou, de maneira mais simples, o fato de que elas são devir porque são tempo e tempo, para Hegel, é devir. Como exemplo, isso é expresso na coloração positiva que a palavra "perfeito" tem no uso hodierno e não é surpresa que em sua etimologia, perfectus, a palavra aponte para acabado, que ilustra bem o que se expressa quando o atributo da perfeição é atribuído a algo. Contra isso é preciso, desde o princípio, ensinar a dialetizar.

É assim e por isso que a reflexão sobre o prefácio, de dentro do prefácio, que toma forma explicitando como este ainda não é a própria Coisa ${ }^{106}$ rapidamente dá lugar ao apontamento de erros dos seus contemporâneos quando de sua apreensão do lugar de suas obras, ou seja, se torna definitivamente tal e qual o Prefácio que o autor havia acabado de definir, mas com a mínima diferença reflexiva sobre si, pequena o suficiente para modificá-lo completamente. A explicação pra isso é relativamente simples e tem a ver com o modo pelo qual podemos compreender a posição de Hegel enquanto filósofo: da sua posição filosófica depreendemos que a ilusão maior não é aquela de não possuir ainda a linguagem conceitual para dar conta da realidade da realidade tal e qual ela se apresenta para nós, como se fosse caso de construir um novo

105 Mais adiante analisaremos detidamente a relação feita por Hegel entre cinismo e romantismo. Por ora, lembremos que para Hegel há no cinismo uma necessidade de manutenção das coisas tais e quais elas são. Em resumo, a postura exclusivamente negadora frente à realidade é uma das formas, eleitas por Hegel, de conservação da mesmidade. Trocando em miúdos, aquele que só reclama dá passos para a manutenção do estado de coisas, pois dele depende.

${ }^{106}$ HEGEL, 1992, p.22. Coisa aqui significa: o conceito de saber absoluto tal e qual ele se desdobrará até o fim da obra. 
vocabulário mais bem acabado e mais perfeito; a ilusão filosófica maior é achar que tal vocabulário exista e possa ser criado. ${ }^{107}$

Isso fica bastante claro se pensarmos que não existe exatamente uma invenção vocabular hegeliana, apenas uma gigantesca tentativa de investigação de seus usos e, quando muito, deslocamentos de sentido pela introdução de certos problemas que as filosofias pregressas já tinham colocado para si. É o que Lebrun deixa bastante claro ao situar a filosofia de Hegel como aquela a partir da qual as outras podem ser julgadas como tendo eleito apenas pressupostos, sem se preocupar com sua investigação ou, ainda, que as filosofias do Entendimento "evitam submeter a significação das categorias a um exame de que a ontologia tem por missão, justamente, dispensar" ${ }^{108}$. É a essa busca de significação muito mais do que a qualquer forma que Hegel está ligado.

Ademais, nesses três primeiros parágrafos, Hegel está também introduzindo uma outra noção e outro deslocamento quando reflete sobre o presente e sobre o que se espera de sua obra. Não podemos nos esquecer que aqui estamos tratando duma época na qual o Romantismo Alemão já está atuante e, se podemos concordar com Paz, que eles foram os primeiros a se colocar como movimento de vanguarda e a produzir discursos sobre sua própria posição ${ }^{109}$, não podemos nos esquecer daquele que influenciou ambos os movimentos (Idealismo e Romantismo alemães), a saber, Kant. É conhecida a imagem da filosofia kantiana como se posicionando de forma a se situar como uma revolução copernicana na filosofia, i.e., uma forma de Kant se situar frente à ciência nascente em sua época e tentar se colocar como sendo seu equivalente filosófico. O problema da imagem, nesse caso, é que ela atualiza uma certa imagem de verdade para os últimos dados científicos, a relação entre filosofia e verdade, por um

${ }^{107}$ Nosso argumento não está contido, mas se baseia bastante nas reflexões de ZIZEK, 2014. Para além de Hegel, se pensarmos, podemos cogitar que foi essa a mudança de Heidegger de sua "primeira" para sua "segunda fase" e foi exatamente essa forma de filosofar que ele abandonou = a de criação de termos e conceitos - ao deixar o projeto de Ser e Tempo inacabado. Deu-se conta de que não era uma questão de ter mais palavras, mas de ocupar outra posição específica na linguagem e na compreensão desta. Não nos parece ocasional que seus cursos sobre Nietzsche e Hegel e sua reflexão sobre a arte tenham sido justo aqueles que serviram de base para alguns comentadores situarem a ruptura de Heidegger com seu pensamento inicial, baseado numa outra sistematização que não aquela que tira conceitos da cartola.

${ }^{108}$ LEBRUN, 2000, p.290.

${ }^{109}$ PAZ, 1984. 
lado tornando a última inacessível, por outro entregando a esperança de acesso às ciências da matemática e da física. Apesar de vetar uma noção realista ingênua de verdade, Kant ainda se coloca como aquele que vai, ele sim, descobrir o verdadeiro vocabulário da metafísica, aquele que faria com que ela se tornasse um discurso veraz. Seria ele, portanto, que daria conta de resolver o "escândalo da filosofia" de não ter fundamentado o mundo de maneira filosoficamente aceitável.

Note-se que, a verdade última é expulsa por uma porta, mas adentra o edifício da filosofia nas ações de Kant. Essa é outra forma de dizer que se ele cresse na inacessibilidade da verdade, creria também, por decorrência, na inutilidade de seu discurso filosófico ou na contradição performativa que é sua escrita. Pois, se a verdade última é de todo inacessível à filosofia, salvo como clarificação de juízos sintéticos $a$ priori, o que é o texto kantiano que lemos? É isso que Hegel nota ao apontar que a cisão coisa-em-si/fenômeno já pressupõe uma coisa-em-si como abstração ${ }^{110}$. Quer isso dizer que Kant ainda parece manter certa nostalgia e esperança na existência de uma coisa em si, algo que Hegel abandona.

Nosso autor é, nessas linhas citadas é, ao mesmo tempo, mais modesto e mais audacioso - e bastante Romântico. É marcadamente deles a ideia de que uma obra (artística ou filosófica) devia considerar sua singularidade e localização históricas ${ }^{111}$. A produção dos discursos sobre si mesmo e a explicitação constante dos pressupostos de leitura para suas obras apontam para isso de forma bastante clara. A ênfase, é claro, é bastante menor do que a que Hegel dá, mas um eco disso se faz ver justo no momento em que ele decide por bem situar sua obra frente à opinião comum, ou seja, frente àqueles que deveriam lê-la. Mais do que isso, todo seu livro já pressupõe tal opinião e, por isso, já se compreende como obra historicamente situada. Essa, uma das diferenças entre Hegel e Kant: a estrutura transcendental kantiana é a-histórica, ao passo que a Razão hegeliana se sabe histórica e, mais do que isso, sabe que se desenvolveu, não é estanque, fixa, imutável. Essa, uma forma de dizer que só se pode falar de dialética quando se compreende que ela é um pensamento do ocaso, muito mais do que um pensamento apoteótico do fim de todas os conflitos.

\footnotetext{
${ }^{110}$ HEGEL, 1992, pp 63-64.

${ }^{111}$ Daí todo um excurso sobre a recusa da opinião pública da época.
} 
Assim sendo, na Fenomenologia, estamos tratando de uma obra que se sabe histórica, situada e que tem por objetivo pedagógico ser justo a ciência das experiências da consciência até a época. Por isso, ela leva em consideração que faz/fará parte das experiências da consciência especialmente daquelas experiências de conhecimento na qual as consciências estão imersas, sendo ainda um sobrevoo por sobre o passado do Espírito. Tanto assim que Hegel afirmará que o que é necessário, por meio da filosofia tornada ciência, é "não tanto o saber do que ele [o Espírito] é, quanto resgatar por meio dela, aquela substancialidade e densidade do ser [que tinha perdido]"112.

Nota-se o entrelaçamento com nossa temática inicial, qual seja, a da formação pelo negativo, com a execução escrita, ou seja, construção da estrutura da obra. Isso porque é a introduzindo (a temática) na forma da própria obra que Hegel a introduz em termos de conteúdo. Ressaltemos que sua manobra ainda tem que se haver com a temporalidade da própria leitura, haja vista que o Prefácio é, também ele, uma forma de seccionar a obra que é historicamente situada. Em um exemplo bastante clássico de “retorno aos gregos", algo tão comum em filosofia, poderíamos exemplificar que as obras de Platão e Aristóteles jamais possuíram esse endereçamento e balanço inicial que Hegel descreve como sendo o prefácio. Sendo assim, desde o ponto de vista de alguém que se sabe situado e sabe dos objetivos de sua obra quanto à problematização dessa situação, a pergunta óbvia que emerge é a seguinte: que maneira melhor de começar do que historicizando, de início, aquilo que é o princípio da experiência da consciência enquanto leitora desta obra específica, a saber, o prefácio, transformandoo em parte daquilo mesmo que se visa ensinar?

Essa reflexão inicial e bastante densa que enxergamos em Hegel tem, assim, um objetivo duplo. Por um lado, objetiva que a reflexão sobre um item do presente ganhe suas conotações históricas que lhe é de direito o que permite, por derivação, que se torne uma compreensão filosófica do próprio prefácio; por outro lado, cumpre a função de prefácio já científico da própria obra de introdução à ciência, de ambas fazendo parte, sem poder delas se destacar. Também assim podemos explicar a diferença gigantesca entre esse Prefácio e os prefácios de obras ulteriores: agora a consciência já

\footnotetext{
${ }^{112}$ HEGEL, 1992, p.24.
} 
sabe (ou deveria saber) que um prefácio não é suficiente, que é o desenvolvimento que importa e que os esclarecimentos ali presentes só poderão fazer sentido depois de toda obra concluída. A consciência sabe, em suma, que filosofia é caminho constante, não paragem estanque. Já perdeu a ilusão de existir algo como uma constituição mais perfeita ou mais acabada noutro lugar. Pode, agora, retornar ao lugar inicial, mas conferindo-lhe outro sentido, inteiramente diverso daquele que possuiria caso não houvesse passado pelo caminho. Pode conferir às proposições ali contidas o sentido de uma proposição especulativa.

Para que possamos ver como o desenvolvimento da obra se dará, no entanto, e para que possamos, ao capítulo três de nosso trabalho, chegar a compreender as proposições especulativas, precisaremos compreender como a linguagem hegeliana é bastante livre de terminologias estanques. Precisaremos compreender então a terminologia hegeliana ou, mais propriamente, sua ausência em teremos de fixidez e o porquê disso já se mostrar no início do percurso.

\subsection{Narrar sem nomear}

Os parágrafos iniciais da Fenomenologia têm a marca do que será, no geral, todo o desenvolvimento da obra completa de Hegel. Diferente das filosofias que o antecederam, o enfileiramento das filosofias pregressas como o desenvolvimento da razão e do Espírito apontam para uma modificação completa na maneira de se conceber a produção do discurso filosófico. Da seguinte forma: se todas as filosofias relevantes até ali desenvolvem, em algum grau, o Espírito, é porque nenhuma delas é possuída por ou possuidora da Verdade final, capaz de resolver todos os problemas; antes, todas estão igualmente corretas e igualmente erradas. Corretas, na medida em que são necessárias ao desenvolvimento; erradas, na medida em que se pretendem o ponto de descanso ou o repouso último do Espírito. Em suma, enquanto buscam cessar o movimento do Espírito sem o reconduzi-lo à autoconsciência, elas incorrem em erro. E isso porque, em grande parte, não colocam para si a questão das condições de possibilidades históricas dos seus respectivos sistemas ou conjunto de conceitos filosóficos o que é o caminho principal para que uma autoconsciência possa emergir. 
Vai daí que a reflexão hegeliana aponta para o fato de que os sistemas são partes da verdade, ou seja, estão em determinado tempo, de determinada maneira. Isso faz com que eles não sejam mais do que momentos, o que impede que qualquer reflexão sobre o Absoluto digna desse nome tenha por pressuposto qualquer outra coisa que não a história e o Espírito. Eis o porquê do que Hegel observa, ainda que sem mencionar nominalmente essa exata falha, em Schelling, no famoso trecho no qual diz ser o absoluto de seu amigo a noite na qual "todas as vacas são pretas"113.

É verdade que Schelling chega a compreender o Absoluto como uma das necessidades do tempo no qual escreve; no entanto, aos olhos de Hegel, sua compreensão parece simplesmente desconsiderar a dimensão de devir inerente a esse Absoluto e, também, a necessidade de uma diferenciação que precisaria existir em seu seio. Uma tal diferenciação não permitiria que se tomasse a natureza como princípio, especialmente não uma que não se desenvolvesse, uma que fosse apenas fundamento da existência. Caso pensasse em desenvolvimento, deveria abandonar a natureza não desenvolta e não diferencial, a filosofia da identidade, portanto, para introduzir um princípio que fosse radicalmente diferenciador e identificador ao mesmo tempo ou, em uma palavra: especulativo. Para Hegel, ao pensar o Absoluto indiferenciado, Schelling desconsidera também a dimensão histórica em seu potencial diferenciador, vez que seria ela quem conferiria a possibilidade de desdobramentos e momentos.

Sobre a correção dessa interpretação de Hegel sobre Schelling preferimos não falar e, em detrimento disso, remeter o leitor à literatura especializada ${ }^{114}$. Todo caso, é importante pensar no quanto esse exemplo já ilustra bem um dos problemas para Hegel, i.e., o fato de que o desenvolvimento não é levado à radicalidade necessária, sendo apenas algo sub-reptício, que ocorre em segundo plano e que, por isso, não consegue atrelar o problema da modernidade ao sistema filosófico. Tudo se passa como se o Sistema não tivesse que ser ele também parte, mas apenas solução do problema. E não pode ser esse o caso, vez que ele também é fruto do problema que quer resolver, mas uma solução de dentro.

${ }^{113}$ HEGEL, 1992, p.29.

${ }^{114}$ KUSSUMI, 2020. BEISER, 2012. 
Sendo assim, elevar o desenvolvimento ao motor mesmo do filosofar é, para Hegel, a forma de responder aos problemas da modernidade, precisamente porque ela já aparece pensada por ele como aquele tempo no qual as suas condições de possibilidade podem ser colocadas de maneira mais radical, o que significa que todo sistema que responde à modernidade precisa se reconhecer formado por ela $e$ performar os mesmos deslocamentos dela na sua filosofia. Ora, para um filósofo sistemático, que pensa o sistema como desdobramento lógico em momentos, que maneira mais radical de colocar uma questão do que a elevação do pressuposto do desenvolvimento ao centro norteador da constituição do sistema?

Por isso que podemos dizer que, é porque quer evitar os mesmos problemas de seus antecessores, que vemos quase como um imperativo para Hegel desenvolver uma forma de filosofar que se diferenciasse profundamente da que ele outrora encontrou. Uma tal diferenciação deve se fazer não de fora, mas de dentro. Parece ser preciso que o ato de fazer filosofia, i.e., a sua própria inscrição nas folhas de uma obra, não permita uma concreção ou pressuposição de verdade estanque, como a adequatio. É mister, portanto, que não se conjugue uma outra doutrina, essa sim finalmente capaz de resolver os problemas, mas que se compreenda que a filosofia precisa, antes de qualquer coisa, refletir sobre a lógica a partir da qual a filosofia se estrutura.

Mas uma mera reflexão, a bem da verdade, muda pouco no campo filosófico, ao menos em termos de lógica. É plenamente possível estabelecer uma forma de filosofar que estabeleça uma mesma lógica ao mesmo tempo em que se critica a forma tradicional de filosofar, ou seja, é plenamente possível que a crítica seja caso de si mesma, ainda que não perceba. Basta, para isso, que a lógica dos mundos não se modifique, que se pense ainda nos mesmos termos, apenas substituindo o que opera quais funções no sistema. O aforismo de Nietzsche segundo o qual "não nos livraremos de Deus, pois ainda cremos na gramática"115 aponta para uma situação assim, já percebida por Hegel: o problema não está em quais conceitos se mobiliza para a compreensão da realidade, mas na lógica estruturante que define o que significa o próprio ato de conceituar. Inclusive o mesmíssimo problema de ligação entre lógica do

${ }^{115}$ NIETZSCHE, 2006, p.26. 
pensamento e gramática aparece naquela obra de Hegel que é anunciada como desvelando a estrutura dessa figura maior, Deus. ${ }^{116}$

Sendo assim, não seria possível, num livro de introdução que já se propõe ser Sistema, que a forma conceitual tradicional, que subsume a multiplicidade à unidade, se mantivesse. Uma tal forma traz indexada a si uma certa forma lógica, por Hegel várias vezes nomeada como cadáver. Nesse sentido, a conceitualização pregressa obedece a uma lógica morta específica para se ordenar, razão pela qual ela mesma aparece como incapaz de lidar com o desenvolvimento em sua vivacidade.

Isso porque, ao abdicar do desenvolvimento lógico em prol da mera proposição vazia de conteúdos concretos, a lógica clássica prescinde, para Hegel, da própria realidade à qual se refere para existir. $\mathrm{O}$ exemplo bastante corriqueiro de relação proposicional e predicativa "Todo homem é mortal/Sócrates é homem/logo Sócrates é mortal" não se importa com a existência de Sócrates, dos homens ou com a questão da mortalidade. É apenas uma abstração que deixa como cadáver o corpo dos seus referentes e funciona a despeito da existência dos termos referidos. A abstração conceitual, nesse sentido, ignora a existência e a fixa numa paralisia da qual o objeto pensado não pode se livrar e a qual é dito corresponder. É, para falar metaforicamente, como se uma vida fosse captada e feita corresponder a uma fotografia: um momento, um centésimo de segundo, uma imagem daquilo é fornecida, o contrário do conceito sendo identificado como não sendo, de maneira nenhuma o referido, ainda que dependa dele para se desenvolver (e.g. "adulto é adulto e criança é criança”).

Para modificar isso, Hegel precisa deslocar - com grande força - o ato de conceitualização. Precisa, portanto, de uma outra lógica, uma que não se permita resumir a uma estrutura terminológica. Trazendo a análise etimológica em nosso auxílio, podemos mesmo compreender que, com esse vocábulo, estamos designando uma secção muito precisa e bem delimitada do discurso, secção essa que quando efetuada faz com que todo uso do vocábulo corresponda a outros usos similares. Hegel, por seu turno, fará seu vocabulário algo que se modifica a cada vez, o que torna sua

116 HEGEL, 2016. Nesse sentido, temos duas antecipações de Hegel a Nietzsche: a morte de Deus, já constante em Fé e Saber; e a ligação gramática-pensamento-Deus, constante na Lógica, Esse é um ganho, cremos, de se estudar a fundo um pensador: notar mais pontos de toque dos que os usuais e já bem conhecidos pontos de discórdia. 
linguagem algo fluido e obediente aos pressupostos que tomou para sua filosofia. Tudo que Hegel escreve modifica de sentido, de modo que termos similares raramente possuem o mesmo sentido sempre. ${ }^{117}$

Ao proceder assim inclusive com a história da filosofia, Hegel faz com que as filosofias pregressas se tornem pedaços de uma mesma história e que a filosofia seja, além do pensamento, história do pensamento. Isso porque ao introduzir as filosofias pregressas numa narrativa maior da qual elas fazem parte ${ }^{118}$, toda e qualquer tentativa de cristalização da própria filosofia que está (ou estava) sendo feita se torna impossível, posto que mesmo aquela parte da história na qual a narrativa culmina (a própria filosofia hegeliana) só pode ser uma parte dela e não sua totalidade. Se a filosofia de Hegel é um sistema aberto e infinito ou fechado e finito é questão outra e, em algum grau, indecidivel ${ }^{119}$; o que é certo é que, para ele, sua filosofia necessariamente decorre das pregressas e o que ele faz, em termos de sua própria lógica, é apenas fornecer a autocompreensão, todo caso ausente nos autores pregressos. Por isso que também o leitor médio, por nós esboçado acima, desde o ponto de vista hegeliano, não reconhece sua formação, apesar de conhece-la bem: é preciso ainda uma etapa e um deslocamento para que isso seja possível e quem a traz, para Hegel, é ele mesmo.

Nesse sentido, nosso leitor, apesar de não saber de nada do que Hegel fala num primeiro momento (nem se saber Espírito, aliás), terá nesse início de Prefácio já uma dimensão do que virá adiante. Uma breve experiência do que significa a descoberta da autoconsciência já se deu nos primeiros parágrafos, nos quais inclusive essa autoconsciência foi abertamente anunciada, conforme vimos: o leitor agora compreende o que é uma seção Prefácio, seus objetivos e pressupostos e pode, por isso, entender como e porque se dará seu desenvolvimento. Dando prosseguimento a ele, se dará conta de que não caberá a possibilidade de pensar em um conceito último que se dissocie da experiência de seu desenvolvimento a partir da perseguição do fio de seu desenvolvimento. Compreenderá, então, a natureza semovente da verdade.

\footnotetext{
${ }^{117}$ BUTLER, 2012, pp.21-23

118 I.e. dizer que um sistema sempre substitui outro muito mais desenvolvendo uma história comum do que anulando o caminhar pregresso.

119 BUTLER, idem, p.23.
} 
Isso, por seu turno, trará consigo um deslocamento da posição do verdadeiro e do falso: "O verdadeiro e o falso pertencem aos pensamentos determinados que, carentes-de-movimento, valem como essências próprias, as quais, sem ter nada em comum, permanecem isoladas, uma em cima, outra embaixo"120. Ora, "carentes-de movimento" não diz outra coisa do que estanques, cristalizados, fechados em si mesmos e apenas por isso adequados aos seus objetos. É preciso, com isso, que o objeto perca uma parte de si, que quem o observa deixe soçobrar um pedaço, que permita que o objeto seja partido, para que ele seja compreendido de maneira estanque e afeita às filosóficas que Hegel critica. Com esse procedimento, a mobilidade que lhe é inerente é removida e o desenvolvimento, por ser esquecido, se torna o falso. Daí sua presença aparecer como se fosse uma situação estranha, uma incorreção mesmo na matriz teorética. Isso porque a coisa não é vista como sendo seu desenvolvimento; antes, a coisa é o que se apreende com uma nomeação exata. A problemática da Richtgkeit, ou seja, da verdade como adequação ou exatidão acaba por mascarar o caráter contraditório inerente à própria verdade porque toma o verdadeiro como o imutável e não contraditório. Eis aí a aliança de que falamos acima entre estratégia de conceituação e lógica.

Por conta de o desenvolvimento ocupar o centro da filosofia hegeliana quando este pensa quaisquer coisas, a verdade não poder ser pensada como "uma moeda cunhada, pronta para ser entregue e embolsada sem mais" ${ }^{121}$. É necessário que a verdade seja reestabelecida, desde o começo, como aquilo que se desenvolve. Se a filosofia tem quaisquer pretensões à verdade, é igualmente necessário que ela também seja pensada como desenvolvimento. Isso não apenas a filosofia de Hegel, mas o conjunto de toda a filosofia produzida até aqui. Quer dizer, o expediente de Hegel não versa apenas sobre o que a obra dele, Hegel, precisa cumprir para ter a verdade "ao seu lado"; ao deslocar o sentido e a maneira pela qual a verdade é compreendida, ele cria a necessidade de uma reformulação do olhar sobre o cânone, sobre o significado mesmo do filosofar. Se todos são momentos da verdade, todos são igualmente dignos de estudo e todos não são mais do que momentos.

\footnotetext{
${ }^{120}$ HEGEL, 1992, p.41.

${ }^{121}$ Ibid, idem.
} 
Para que a filosofia de Hegel se possa cumprir, portanto, o parágrafo que insiste no reexame das contradições das filosofias precedentes como desenvolvimentos do Espírito (realizado de maneira mais detida nas Lições sobre História da Filosofia) é fundamental, pois aponta para a maneira pela qual a lógica de Hegel (lembremos, já pressuposta aqui) informa sua maneira de construir história tanto da filosofia, quanto do mundo. Se é verdade que o Espírito quando conta sua história procede a partir de totalizações $^{122}$, é igualmente verdade que ela as faz a partir de uma lógica que é aquela descrita de maneira direta na Lógica.

Importante notar, aqui, o uso do vocábulo desenvolvimento (Entwicklung) que repetimos constantemente. Não é pressuposto, aqui, nenhum tipo de melhoria quando algo se desenvolve, quer se pense do ponto de vista moral, quer se pense do ponto de vista epistemológico. Dizer que algo se desenvolve, evolui, ou progride são três formas de dizer que, dado um determinado referencial específico, aquilo de que se fala caminhou mais em direção aquilo. Assim, desde o ponto de uma possibilidade de morte, uma doença evolui para óbito; desde o ponto de vista de um câncer ele se desenvolve para uma metástase e a eventual tomada de assalto do corpo; desde o ponto de vista de uma saída da prisão para um detento e de seu retorno à liberdade extramuros, falamos que ele teve "progressão de regime". Não há, em nenhum dos três vocábulos e empregos, sentidos absolutos; há, antes, uma observação do quanto algo se aproximou do critério previamente adotado. Certamente é isso que Hegel tem em mente ao empregar o vocábulo e falar em desenvolvimento da verdade (Entwicklung der Warheit $^{123}$. Deduz-se disso que não é que a verdade ficou mais desenvolta ou "mais verdadeira", mas que o Espírito progrediu mais em direção à sua autoconsciência e, por isso, se aproxima mais da verdade. Afirmativa que tem por suporte o segundo parágrafo da abertura do capítulo quatro da obra que ora analisamos: "com a consciência-de-si entramos, pois, no reino (Reich) da verdade"124. É a partir de uma autoconsciência da figura da consciência, portanto, que o progresso em direção ao Espírito e à autoconsciência deste se dará. Esse, o critério maior do verdadeiro para Hegel.

\footnotetext{
122 SAFATLE, 2016.

123 HEGEL, 1992, p.22.

${ }^{124}$ HEGEL, 1992, p.120.
} 
Seria possível arguir que isso é melhor do que antes, uma vez que seriam ganhos frente à posição anterior. Ao fim e ao cabo, teríamos um campo quantitativamente maior de percepção e de desenvolvimento, a consciência teria caminhado mais e reconheceria mais coisas que antes não reconhecia. Mas as noções quantitativas são, também elas, abstrações nesse caso. Todos os passos são igualmente necessários $e$ conservados. Como a figura é de um círculo que já se inicia pelo fim, a ideia de progredir como melhorar já começa inexistente porque não há um objetivo exterior, ou seja, não há fim no sentido de uma externalidade. É, assim, uma música de tempo infinito.

Por conta de sua circularidade e por ser a antessala de todo o pensamento e sistema a Fenomenologia, em seu começo, já deve ser capaz de apresentar todas as inversões e interversões que a obra, em particular, e o Sistema, no geral, deverão produzir. Sendo esse o caso, será também caso de pensar nesse princípio a partir do qual o desenvolvimento de uma planta é pensado como um momento específico do negativo, ou seja, é invertido em relação ao senso comum. Pois o que acontece aí não é simplesmente o caso simples de uma troca de ênfase, i.e. normalmente pensaríamos a mudança como simplesmente e evolução natural e Hegel estaria propondo uma leitura “ao contrário". Não. Aqui o que vemos é a continuidade de um processo pensado à luz da dialética e estamos vendo, também, como a morte e a vida não são existências absolutamente distintas, separadas, estanques, mas continuidades necessárias de um mesmo processo. São partes de um processo de suprassunção, que eleva, nega e conserva, precisamente o que ocorre a cada momento da planta descrita por Hegel. Tudo, desde o começo até o fim, conserva o caráter inicial da semente; a cada momento, no entanto, será uma parte específica que sofrerá os processos de negação ou elevação. Ressaltemos ainda outra vez: não é apenas uma leitura "pela morte" ou que Hegel propõe, mas uma leitura na qual o negativo seja visto como um Si e não como uma exterioridade. $^{125}$

É claro, no texto, que o exemplo é escolhido tendo em vista a organicidade do processo dialético, mesmo que se busque pensar a vida natural, de todo incapaz de suportar a eternidade do conceito. Mas é igualmente claro que Hegel está buscando

${ }^{125}$ HEGEL, 1992. 
uma maneira de demonstrar como a contradição é constituinte e não apenas erro, posto que ali ela não aparece como uma unilateralidade; antes, aparece, mesmo na natureza, como um dos "momentos mutuamente necessários"126 ao desenvolvimento daquele ente. É verdade que a natureza não pode figurar como o espelho do mundo posto que ele é, antes de qualquer coisa, lógico ${ }^{127}$; apesar disso, ela pode ser citada e pode ser exemplo, porque nela tudo é contingência e movimento.

Nesse sentido, há que se notar a maneira como existe, já nesse procedimento hegeliano, uma introdução da noção de movimento como central ao pensamento. Numa primeira leitura, nota-se apenas a mudança de uma conceitualização que se faz de forma estanque a um movimento que diz respeito à existência. Após os ganhos oriundos do caminho da obra, pode-se notar que não temos aí apenas um exemplo para pensarmos por contraste ou contraluz; temos, em verdade, o movimento mesmo da realidade já nos sendo apresentado tal e qual ele também figura no Espírito. Não é um mero exemplo, mas uma apresentação da dialética. Parece-nos uma das muitas vezes que o rigor hegeliano não deixa "nada de fora".

Que se note aqui que o uso acima de "Espírito", por nós, não foi algo casual. A consciência inicia sua leitura da obra apenas e sabendo consciência individual, que compreende objetos como opostos a si e se compreende como absolutamente distinta da realidade na qual, no entanto, está colocada. Após o capítulo "Razão", a consciência já se compreende como Espírito, pois já sabe da relação identitária existente entre ela e a realidade e já pode, com isso, compreender suas etapas de formação, i.e. as etapas de formação do Espírito que serão também as suas. Ora, uma vez que quando reencontra o Prefácio não o faz mais como consciência, mas como Espírito, a leitura deste trecho por nós ressaltado não poderá se circunscrever apenas à noção de um exemplo; deverá, antes, aparecer ao Espírito como a maneira pela qual a realidade se anima, o modo mesmo pelo qual o real se desdobra diante de seus olhos e em si mesmo, pois entre um e outro não há mais quaisquer diferenças.

${ }^{126}$ HEGEL, 1992, p.22.

${ }^{127}$ Daí a Enciclopédia começar pela Ciência da lógica e progredir até o Espírito; a natureza, segundo tomo da referida obra, é um momento de alienação do Espírito, mas ela funciona sob as mesmas regras lógicas faltando sua autoconsciência, tema do terceiro volume que versa justo sobre o Espírito. 
Se preferirmos uma versão mais precisa, a diferença não está mais na dissimetria entre o olhar do observador e a realidade (como em Kant com sua noção de coisa em si). A dissimetria percebida já é aquela que existe entre a coisa e ela mesma, pois "se esse negativo (entre olhar e a coisa) aparece primeiro como desigualdade do Eu em relação ao objeto, é do mesmo modo desigualdade da substância consigo mesma"128. Não tanto uma impossibilidade de apreender a verdade das coisas por incapacidade, mas uma opacidade que está presente no núcleo mesmo das coisas: tal deslocamento faz com que o negativo não seja tanto um defeito nas coisas, mas sua própria condição de existência. Razão pela qual a linguagem que dele terá de dar conta precisará, também ela, conter em si mesma negatividade, sob pena de ser considerada insuficiente.

Dito tudo isso, entendemos o porquê de Hegel pensar um tipo de filosofia como vinculada a um certo comportamento linguístico ${ }^{129}$ : a linguagem, para que seja o móbile do pensamento que é para Hegel, precisa ser capaz de constituir a maneira pela qual o homem compreende e pensa o mundo e também a maneira pela qual se coloca nele. A forma como ela é manejada e os comportamentos alinhados ao manejo serão definidores do tipo de filosofia que se tem. A filosofia, nesse sentido, é um manejo da linguagem que busca eleva-la ao conceito ou, lendo sua equiparação entre gramática e lógica, elevar a linguagem hodierna à lógica.

Dada a equiparação feita pressupor uma noção de familiaridade entre a linguagem comum e a filosófica, Hegel precisará demonstrar, para que sua jornada possa ter algum lastro, que a linguagem é precisamente quem introduz o negativo para o homem e quem fornece, por isso, a possibilidade de compreensão de seu lugar no mundo. Isso porque, se não for esse o caso, não se tratará mais de um estudo da formação feita com base a conferir-lhe a possibilidade de reconhecimento, mas um outro sistema que suplanta o anterior, reproduzindo a lógica das filosofias precedentes.

Por isso, será através de um extensivo trabalho de deslocamento de sua posição na linguagem - de uma linguagem representativa para uma propriamente conceitual nos termos que ele define conceito - que a consciência poderá devir Espírito. Será,

\footnotetext{
${ }^{128}$ HEGEL, 1992, p.40.

${ }^{129}$ HEGEL, 2017.
} 
também, dentro de uma compreensão muito particular de sistema e ciência que uma linguagem poderá ser pensada, dado que a noção de sistema, quando reformulada, dará a forma de escrita para que os outros sistemas (e Hegel por vezes dá a entender que compreende que praticamente toda filosofia anterior à sua era um sistema, como no parágrafo acima analisado) sejam englobados. Dito de outra forma, reformulando a relação entre sistema e ciência e, por tabela, entre sistema e verdade - ambas feitas a partir de sua noção de desenvolvimento da verdade e da verdade como desenvolvimento - Hegel acabará por circunscrever a linguagem num campo muitíssimo específico, campo esse que é aquele de sua dialética. Posto que entre seu sistema e os outros existirá uma continuidade, será possível deduzir daí que também existem continuidades entre a linguagem das filosofias pregressas e a sua, posto que todas são oriundas do mesmo processo de formação, apenas em etapas distintas. Essa, uma das razões maiores para que Hegel inicie o primeiro capítulo de sua narrativa e jornada com uma crítica do agora e do isto e dos tempos presentes a ele subjacentes. Falar do presente é uma das formas de escamotear o desenvolvimento e o negativo e inscrever tais procedimentos na linguagem que, aqui, evoca o tempo.

Sendo assim, precisamos apreender melhor a relação entre sistema e ciência, bem como entre sistema e linguagem para que possamos chegar à passagem das proposições raciocinantes às proposições especulativas, esta última uma noção lógica utilizada para compreender o processo de formação. Compreendendo isso, poderemos entender de que maneira Hegel, ao analisar a formação, já está, também ele, efetuando uma passagem formativa no leitor, entrelaçando ambos os procedimentos em um só. 


\section{3}

\section{A linguagem como negativo}

Como falaremos de negativo, é importante que abordemos uma certa possibilidade de leitura de Hegel, possibilidade essa que apregoa a ele uma certa resistência à diferença. Afinal, não foi ele aquele quem inclusive introduziu o devir no sistema de modo que nada ficasse de fora? Não foi ele quem pensou num Espírito Absoluto que se desenvolveria a partir da diferença englobando-a constantemente e a devorando, fazendo-a tornar-se identidade ainda que à sua revelia?

A figura, embora difícil de situar em termos textuais, assombra a todos de um modo tão ou mais evidente do que aquela da dialética em três termos ${ }^{130}$, de modo que a mera descrição nesse texto fará o leitor recordar do que se fala aqui. Falamos daquela leitura de Hegel que o vê como o opressor da diferença ${ }^{131}$, o sistematizador que parece dar à diferença uma cidadania apenas para usurpá-la no futuro ${ }^{132}$, ou da figura pintada por Foucault, de um Hegel tão pervasivo que precisaríamos tomar precauções, afinal

"é necessário que se saiba até onde, insidiosamente talvez, ele se aproximou de nós; é necessário que se saiba o que há ainda de hegeliano naquilo que nos permite pensar contra Hegel; e é necessário que se avalie em que medida é que a nossa ação contra Hegel não será talvez ainda uma armadilha que o próprio Hegel nos coloca e no termo da qual ele nos espera, imóvel, noutro lugar."133

Independentemente da posição adotada frente a Hegel, a questão toda é que se posicionar a partir dele é algo que parece uma necessidade pela simples menção do nome. Tudo se passa como se, máquina de moer diferenças, autor que é uma influência insidiosa - para usar o termo de Foucault - ou sistematizador de todo saber, Hegel precisasse ser necessariamente uma figura sobre a qual se fala, sobre a qual se produz discursos filosóficos, portanto. Para além de uma simples apreciação de sua filosofia, no entanto, aparentemente, ao menos para esses três autores da diferença, se trata,

\footnotetext{
${ }^{130}$ A famosa tríade "tese, antítese, síntese".

${ }^{131}$ Cf. DERRIDA, 1967.

132 Cf. DELEUZE, 1968.

${ }^{133}$ FOUCAULT, 1999, p.72.
} 
sobretudo, de pensar o que se perde na noção de sistema, essa que parece a tudo englobar e encaixar em um determinado lugar, até mesmo a diferença. Mas a dúvida que precede uma tal reflexão é um tanto quanto simples, apesar de poder ser um tanto perturbadora: o que quer "sistema" dizer em Hegel?

\subsection{Sistema e Ciência}

Retornando ao prefácio da Fenomenologia de onde a deixamos vemos que, se seguindo à temática do resgate do saber do Espírito, inicia-se uma longa consideração acerca das filosofias da época de Hegel e, também uma longa reflexão acerca da ciência. Pois bem, em toda a sua reflexão que se segue, será caso de refletir sobre o porquê de a possibilidade de transformar a filosofia em verdadeira ciência ter se dado apenas na época e na presente obra. Tudo isso se deverá a uma nova formação do Espírito, de modo que a ciência que agora se afirma de maneira firme só pode fazê-lo porque certas etapas já foram passadas, i.e., no passado e em sua passagem as condições foram criadas. Afirmará Hegel:

"o começo do novo espírito é o produto de uma ampla transformação de múltiplas formas de cultura, o prêmio de um itinerário muito complexo, e também de um esforço e de uma fadiga multiformes. Esse começo é o todo, que retornou a si mesmo de sua sucessão [no tempo] e de sua extensão [no espaço]; é o conceito que-que-veioa-ser conceito simples do todo. Mas a efetividade desse todo simples consiste em que aquelas figuras, que se tornaram momentos, de novo se desenvolvem e se dão nova figuração; mas no seu novo elemento, e no sentido que resultou do processo" 134

Para destrincharmos essa parte, é importante que entendamos bem o que significam as partes em negrito. Essa figura de um todo que perfaz seu próprio movimento e retorna sobre si mesmo é a mesmíssima figura do Hegel, autor, escrevendo e nos transmitindo a história do Espírito em sua obra. Nesse sentido, a escrita da Fenomenologia é a escrita da ciência e dos movimentos do Espírito na medida exata em que ela é aquele "cinza sobre cinza" do qual Hegel fala na Filosofia do Direito. O movimento de escrita conceitual e a construção sistemática, com o

${ }^{134}$ HEGEL, 1992, p.27 (grifo nosso, itálico do autor). 
deslocamento e o engendramento da realidade que lhes é inerente ${ }^{135}$, só é possível na medida em que ele é uma mimese e uma explicitação do movimento do próprio Espírito ou, se se preferir, só é possível na medida em que é um processo ativo que se inicia, ato contínuo, ao fim de uma época. Longe de apenas anunciar uma época nova e bem circunscrita, como parece dar a entender, Hegel está muito mais sinalizando o final da época precedente e a possibilidade da passagem da concreção à lógica, ou seja, a logicização que corresponde à transformação em efetividade (Wirklichkeit). Se esta época é aquela na qual a filosofia poderá deixar de se chamar de amor ao saber para se tornar saber efetivo $^{136}$, é apenas por sobre o cadáver da época precedente que agora nos é posto para dissecção conjunta.

Não é por acaso que, logo adiante, encontramos uma frase que explicita justo que "embora a primeira aparição de um mundo novo seja somente o todo envolto em sua simplicidade (...) para a consciência, a riqueza do Dasein anterior ainda está presente na rememoração" ${ }^{137}$. Todo o esforço de uma tentativa de rememorar a riqueza anterior e trazê-lo à tona (que é a função da Fenomenologia) precisa ser sistemático uma vez que o que importa não é fazer um inventário da contingência, mas uma história da Necessidade ${ }^{138}$. Este último termo só entra em jogo na medida em que o evento já se foi e causou rachaduras e impactos no Espírito. É só porque aquela contingência, ao ocorrer, fez com que um império ruísse, uma guerra se deflagrasse ou uma biblioteca queimasse que ela se torna necessária ao Espírito configurando, assim, um caso de necessidade a posteriori. Essa transmutação no Espírito é observada pelo filósofo que por sobre a história se debruça e, como é do Espírito que ele conta a história, uma contingencia assim capaz de constituir o presente do autor é por ele ressaltada como algo necessário ${ }^{139}$. No entanto, nada garante que a contingência não pudesse ser outra coisa. Ela se torna necessária na medida em que ela aponta para a necessidade do presente que anima a retomada do passado. ${ }^{140}$

\footnotetext{
135 Isso se torna explícito na Lógica:

${ }^{136}$ HEGEL, 1992, p.23.

${ }^{137}$ Idem.

${ }^{138}$ LEBRUN, 1988, p.38.

${ }^{139}$ LEBRUN, 1988, p.30.

${ }^{140}$ SAFATLE, 2016.
} 
O que se poderia questionar imediatamente após a leitura deste parágrafo é: mas por que é necessário se perfazer toda a história do Espírito dentro de um Sistema e não, simplesmente, dentro de uma constelação conceitual esparsa, sem uma ordenação rígida? Ora - responderíamos - o Sistema de Hegel é um composto de desdobramentos de Necessidades não apenas criadas, mas contidas naquilo mesmo de que se fala. Assim, sua história, por ser um processo narrativo e dialético, por princípio já implica escolhas de elos que se provaram causais no momento exato em que se observou o movimento de um polo ao outro. Sendo assim, o Lógica confere à história (e à Fenomenologia, por derivação), a estrutura dentro da qual a história, pensada enquanto rememoração ativa, pode se desdobrar. Do mesmo jeito que cada categoria da Lógica ou da Enciclopédia faz a outra nascer ao transmutar dialeticamente nela, cada momento do Espírito fez o outro nascer ao se transmutar nele. A morte e a vida acontecem ao acaso, e não guiados pela providência, razão pela qual Lebrun pode chamar a história hegeliana de "verdadeira teodicéia"141; no entanto, certos momentos são definidores de um novo estágio do Espírito e, por isso, tudo o que leva até ele e constrói sua necessidade, bem como ele mesmo, se tornam necessários. É, por isso, uma necessidade a posteriori.

Estamos aqui, ao mesmo tempo distantes e próximos de Karl Löwith em sua leitura sobre o sentido da história em Hegel. Se é bem verdade que ele afirma que os homens são utilizados pela razão de dentro de suas paixões, ou seja, "pessoas, enquanto indivíduos, não sabem o que elas estão de fato fazendo" ${ }^{142}$, é igualmente verdade que ele também defende que a astúcia da razão aí descrita é uma "leitura da providência divina" como força que guia as ações humanas. ${ }^{143}$ Pensamos não ser o caso, uma vez que quem diz guia diz previsibilidade e realização de um jogo de cartas marcadas, além de um progresso constante e seguro, coisa que o espírito nunca faz. A imagem do círculo de degraus de Hegel ${ }^{144}$ mostra bem a circularidade bem como os altos e baixos ${ }^{141}$ LEBRUN, 1988, p. 25.
${ }^{142}$ LÖWITH, 1949, p.56.
${ }^{143}$ Ibid, p.57.
144 "A vida do espírito presente é um círculo de estágios/degraus (Stufen) que, por um lado,
cem em simultâneo e apenas por outro lado aparecem como passados. Os momentos que o permanecem em simultâneo e apenas por outro lado aparecem como passados. Os momentos que o
espírito parece ter atrás de si, ele também os tem em sua profundidade presente." (HEGEL, 1986 p.105). Especialmente nessa citação preferimos traduzir e citar diretamente do original em alemão pelo múltiplo sentido de Stufen. 
da história, de todo condizentes com a concepção hegeliana, são também presentes na atualidade.

Ademais, se fosse o caso de existir uma providência que guia, seria caso também de pensar que Hegel pensa em sua malevolência o que não encontra respaldo textual nenhum. Ao contrário, Hegel realmente afirma que as paixões são os motivadores da história ao mesmo tempo em que afirma que nenhum homem terá das ações que executa conhecimento histórico, posto esse ser sempre insondável.

O Saber Absoluto, nesse sentido, não é saber de quaisquer coisas empíricas no momento em que ocorrem, mas apenas o próprio desdobrar do pensamento que funciona de forma a ordenar a história ocorrida. Isso foi o que Gadamer viu bem ao salientar que "o movimento especulativo é designado por Hegel como plásticoimanente, ou seja, ele se forma continuamente a partir de si mesmo"145, i.e., não há nada na história de Hegel que não seja o próprio pensamento refletindo sobre si e organizando sua própria constituição. Um tal movimento, quando tenta explicitar também a concreção, precisará conferir a ela formas que sejam mais adequadas e porque percorrerá apenas aquelas formas que ele mesmo já tem. Dito de outro modo, Hegel não se interessa em pensar outramente se, com isso, estivermos pensando em constituições outras que a moderna; antes, seu outramente se referiria à própria ideia de que o que temos é uma formação - à época uma novidade.

Como não existe uma exterioridade a partir da qual se possa falar, posto ser um Sistema que se deduz desde o princípio a partir das próprias categorias, Hegel simplesmente tem de obedecer à lógica própria do conceito ou do objeto (nesse caso o saber ${ }^{146}$ ) que tem a frente, sem jamais poder pensá-la com um apelo a algo que nela não esteja desenvolvido. O paradoxal movimento, aqui, é que Hegel já esteja ciente do fim do processo antes mesmo de inicia-lo. Poderíamos bem usar contra o autor tal fato. O acusaríamos de apenas fazer uma pantomima com o movimento e a diferença, de nunca se mover de onde de fato está, sendo apenas um bom dramaturgo que, no fim, não mudou nada e não fez nada se mover. Mas, como é uma "filosofia insidiosa", também esta objeção já resta rebatida de antemão: considerando que tudo que é

\footnotetext{
145 GADAMER, 2012, p.30.

${ }^{146}$ HEGEL, 1992, pp. 66-70.
} 
filosófico se assenta numa historicidade terminada, conhecer o fim do processo não o invalida, mas se torna condição de possibilidade para seu início. Isso não torna a filosofia hegeliana um mero jogo de ligue os pontos, pois quando se tem o começo e o fim do trajeto (já que são o mesmo) ainda resta saber por quais caminhos se deve correr. Em outras palavras, equivale à demonstração de Hegel, que consiste em mostrar como o verdadeiro deve ser concebido "não como substância, mas também como sujeito." ${ }^{147}$ Isso quer dizer: não apenas de maneira que seja algo como diante da vista, algo externo, exterior, um fora radicalmente outro ao qual não me identifico, mas, também, como reflexão, identidade, auto consciência.

Todo esse procedimento, justo porque precisa guardar a complexidade de uma diferença que se faz sempre presente, de um negativo que nunca se esgota apesar do fim já ter chegado, só é possível num sistema que se desdobre constantemente e que permita o retorno ao tempo do qual fala, sem que esse retorno deixe de transmitir o frescor da contingência. Para que tal frescor se preserve, é preciso que uma distância se interponha entre o ato de escrever e a realidade, de modo que, apesar do primeiro compreender a segunda, ele nunca o fazer ao modo de uma adequatio. Se o Conceito engendra uma realidade ${ }^{148}$, ou seja, é capaz de gerar outro objeto toda vez que passa em seu oposto, é porque é capaz de alterar fundamentalmente aquela realidade que se mostra, fazendo com que um fenômeno se transforme em seu outro, a comparação de ambos demonstrando que houve, de fato, uma realização da alteridade no sentido mesmo que de foi capaz de se tornar real. A alteração é tão drástica, para Hegel, que, segundo Löwith,, Hegel chega mesmo a afirmar que está convencido de que a realidade não resistiria caso as interpretações e representações fossem mudadas ${ }^{149}$.

É também por isso que é tão vago - além de empobrecedor - utilizar o esquema tese, antítese e síntese para explicar a dialética. Seja desde o ponto de vista da consciência que antecipa o todo ou desde o ponto do desdobramento do todo, cada momento é experimentado pela consciência como sendo uma nova etapa, um novo episódio a ser suprassumido e constituir a identidade da identidade e da não identidade. Ao dividir em tese/antítese/síntese, perde-se a riqueza da passagem e a própria noção

\footnotetext{
${ }^{147}$ HEGEL, 1992, p.29.

${ }^{148}$ HEGEL, 2017.

${ }^{149}$ LÖWITH, 2013, p.51
} 
de conceber inerente ao conceito hegeliano ainda por um outro viés: tese e antítese pressupõem externalidade metodológica, ao passo que o que Hegel quer mostrar é justo que toda categoria é "implicitamente contraditória" 150 . É também aí que o conceito cria a realidade, posto que seu automovimento é o automovimento do real em sua logicidade e, ao fazer cair a contingência, instaura um real não visível quando esta é considerada como parte fundamental, i.e., quando o evento ainda está ocorrendo (pensando na dialética inerente às coisas efetivas, como em nosso livro em questão).

Ademais, se o conceito é capaz de criar uma realidade, é na medida em que ele permite ver sua própria intromissão no real, como se fosse um excesso que tentasse dar conta de uma opacidade ${ }^{151}$. Em tal excesso - que é de negatividade por excelência introduz-se o elemento histórico do próprio ato hegeliano o que leva a compreensão desse ato como histórico e crítico, principalmente na Lógica. Justo porque se sabe atuante - posto ser reflexivo - ele pode, ao mesmo tempo, resguardar a intensidade da Diferença e da Contingência e propor uma série de Necessidades. Dito de outro modo: é porque o sistema hegeliano é passível de ser compreendido por ele mesmo (por suas categorias e sua dialética), ou seja, porque pode ser objeto e sujeito, que pode fazer uma tal conservação. É porque o Sistema de Hegel não quer ser outra coisa que o caminho que vai de substância a sujeito que ele pode comportar a vivacidade do movimento ao mesmo tempo em que escolhe destinações e paradas.

Pensando a partir de uma contraposição, não se trata, aqui, de uma filosofia do absoluto da identidade que elimine a diferença. Assim, o erro de Schelling, aquele que teria, segundo Hegel, feito com que seu absoluto fosse uma noite no qual "todas as vacas são pretas" 152 , só pode se tornar efetivo, entre outras coisas, porque Schelling não historiciza o próprio fazer de sua filosofia, ou seja, porque ele, apesar de já pensar em desenvolvimento lógico e numa microhistória do Espírito, ainda não se compreende como parte dele de maneira suficiente, posto que sua própria historicade - a julgar pelo diagnóstico de Hegel - não está em jogo. Assim, não consegue conceber o movimento diferenciador inerente ao negativo.

\footnotetext{
${ }^{150}$ FORSTER, 1999, p.132.

151 ZIZEK, 2014, p.19.

152 HEGEL, 1992, p.29. Retraduzimos “de gatos são pardos” para o sentido literal.
} 
Desde o prisma de Hegel, as categorias devem refletir tal compreensão, de modo que, como Butler enfatiza, elas mesmas ganham significado ao longo da leitura. ${ }^{153} \mathrm{O}$ próprio fato de nem sequer as definições poderem ser buscadas previamente ou estarem fixas já indica o tipo de deslocamento inerente a uma filosofia que se quer ciência, ao menos aos olhos de Hegel. Nada diferente do esperado, especialmente se pensarmos que a crítica ao formalismo ${ }^{154}$ e a contraposição com a anatomia $^{155}$ mostram bem que o que falta em ambas as ciências é a consideração da vida, pensada enquanto "movimento do pôr-se-a-si-mesmo, ou a mediação consigo mesmo do tornar-se-outro". 156

É importante ressaltar que um sistema, como qualquer outro tipo de obra, precisa de um começo. Sendo assim, é preciso que um ponto seja escolhido, um movimento radicalmente original surja e os critérios para sua escolha podem ser lidos, sempre, como radicalmente arbitrários. O problema do começo e a solução que se confere a ele serão capazes de nos mostrar o tipo de crítica que Hegel empreende, já em sua primeira obra, daquilo que se pode chamar de verdade como adequação.

É típico da filosofia de Hegel equacionar a ida aos fundamentos como justo a perda desse começo e desse fundamento almejado. Isso é consequência do fato de que a filosofia só pode ser pensada como um sistema, nos diz Hegel ${ }^{157}$, que tem em seu final a justificativa do seu começo e, por conseguinte, do trajeto. Nesse sentido os desdobramentos que ocorrem a partir de uma proposição que conferiria os fundamentos se torna justificado ao fim, de modo que as contraposições que foram leitvmotiv do desenvolvimento aparecem como justificadas. Essa é a razão pela qual Hegel pode afirmar, das proposições que miram o fundamento e que não se justificam ao fim que "uma assim chamada proposição fundamental (ou princípio) da filosofia, se é verdadeira, já por isso é também falsa, à medida que é somente proposição fundamental ou princípio" ${ }^{\prime 158}$.

\footnotetext{
${ }^{153}$ BUTLER, 2012, p.18.

${ }^{154}$ HEGEL, 1992, p.29

${ }^{155}$ Ibid, p.21.

156 Ibid, p.30.

${ }^{157}$ Ibid, p.33.

${ }^{158}$ Ibid, Idem.
} 
Essa compreensão parte de um começo como sendo sempre essa grande figura do negativo que o tempo todo, ao ser pensada, já evoca sua contradição justo por não poder ser afirmada como verdade, e isso é precisamente o motor do que se configura como uma demonstração dialética. É como se Hegel assumisse que certo começo aparentemente brusco, abrupto ou simplesmente arbitrário fosse necessário para a filosofia, caindo por terra sua arbitrariedade no fim da demonstração do sistema. Assim, todo começo é uma aposta que só se concretiza na totalidade da exposição e no retorno necessário feito após o já exposto ganhar corpo. Isso só pode ser pensado dessa maneira porque o saber de Hegel não é o saber que puramente incide sobre os objetos, não é uma representação adequada da realidade exterior, mas uma reflexão sobre o fenômeno. Nas palavras de Gadamer, que refletem sobre o procedimento hegeliano, podemos escutar que "saber do ente, ele é sempre é, ao mesmo tempo, saber do saber" ${ }^{\prime 59}$ o que significa que toda reflexão tem por finalidade demonstrar a construção e a justificativa desse saber do saber, orientando-o para aquilo que desconhece, a saber, seu caráter de formado.

Notemos, ainda que como um breve excurso, que a ida aos fundamentos em Hegel será tida como perda dos fundamentos também na Lógica. Assim, na Doutrina da Essência, lemos quando Hegel discorre sobre a oposição positivo e negativo, que "eles vão ao fundamento (Sie sich grunde)" e, logo posteriormente, lemos que a oposição "não apenas foi ao fundamento, mas também retorna ao seu fundamento (ist der Gegensatz nicht nur zugrunde, sondern in seinen Grund zurückgegangen)"160. Curiosamente, esse movimento, a bem da verdade efetuado a nível de essência e não ao nível do ser (é o segundo volume da Lógica, afinal), pôde ser pensado a partir de um uso e exploração linguísticas do alemão, mas a noção, no geral, não é exclusiva da língua. Se pensarmos o que Hegel está propondo, podemos afirmar que ele está propondo que o próprio movimento que busca um fundamento, uma base, uma estabilidade, já pode ter por expectativa o seu fracasso porque objetualidade e objetividade estão sempre interligadas. A figura do círculo, que remete o começo ao fim, indica bem que a filosofia hegeliana se vale desse perpetuum mobile, algo que a

\footnotetext{
159 GADAMER, 2012, p.20

${ }^{160}$ HEGEL, 2017, pp.81-82.
} 
caricatura de Feuerbach ${ }^{161}$, segundo a qual o sistema teria que ser lido obsessiva e infinitamente, exacerba bem e, malgrado o tom crítico, permite perceber o que Hegel concebe como filosofia: um movimento de remissão e rememoração, sim, mas sobretudo um movimento de demonstração desses conceitos que já se mostram como formados, apenas não bem deduzidos e expostos ainda. A versão fenomenológica disso aparece de maneira mais clara quando Hegel afirma que o em si não é só em si, mas um em si para a consciência, de modo que a construção do ensimesmamento modifica o que se tem por em si. Essa é outra forma de dizer que fundamento já pressupõe o objeto fundado e esse, por seu turno, está implicado no fundamento ${ }^{162}$.

Vem daí também o porquê de simplesmente ser impossível pensar a filosofia a partir uma proposição fundamental, especialmente quando esta última necessariamente assume a conotação daquilo que Hegel chama de proposição raciocinante, que veremos mais detidamente adiante. No que respeita a essa terminologia e sua aplicação aqui, podemos adiantar que por ser geralmente já juízo acerca de um objeto e por juízo já pressupor uma cisão, tal não será a forma adequada a filosofia. Além disso, tal forma conta com uma exterioridade fundante que não se encontra em lugar nenhum, de modo que denota a impossibilidade de compreensão do caráter formativo necessário a cada objeto quando este é construído.

Desdobrando um pouco mais, o juízo já pressupõe, em si mesmo, a relação sujeito-objeto, situando aquele julga numa posição diferente daquela do objeto que ele toma para apreciar. Ora, para um filósofo que está justo se preocupando em abolir a noção de que os termos dessa relação sejam duas entidades distintas e incomensuráveis, utilizar-se dessa noção seria um despropósito, especialmente porque, com isso, seu sistema se transformaria numa mera coletânea de proposições que não possuem, necessariamente, nenhuma conexão entre si. Seria uma Enciclopédia no sentido que Diderot a produziu, ou seja, uma série de saberes relevantes, mas que não possuem um fio de necessidade os ligando. Em suma, terá faltante o caráter de ciência e, por conseguinte, o de desenvolvimento, uma vez que só "o espírito, que se sabe desenvolvido assim como espírito, é a ciência"163 i.e., somente a autoconsciência do

\footnotetext{
${ }^{161}$ FEUERBACH, 2012, p. 35.

162 HEGEL, 1992, p.71.

${ }^{163}$ HEGEL, 1992, p.34.
} 
Espírito, critério fundamental para Hegel em boa parte de seus escritos ${ }^{164}$, valida o que quer que seja.

Nota-se, então, que o caráter de entrelaçamento ou copertencimento necessário entre ciência e sistema se faz majoritariamente pela noção de desenvolvimento, um dos muitos termos a partir dos quais a dialética será apresentada. Isso é enfatizado tanto na Fenomenologia quanto na maneira de escrever a Enciclopédia, posto que ela é muitíssimo diferente de um amálgama de conhecimentos e, justo por isso, pode ser uma enciclopédia das "ciências filosóficas". Nos dois casos, trata-se de se debruçar sobre e esclarecer o caráter formativo e de formado do Espírito, de modo que desenvolvimento opera a função lógica própria a esses dois atributos. Isso porque o nome lógico para formação é desenvolvimento: este exclusivamente lógico, aquela, pressupondo contingência e finitude.

Em consequência da ligação que a noção de desenvolvimento faz entre sistema e ciência, é possível afirmar que algumas noções em Hegel, incluindo as já citadas, possuem uma interconexão fundamental. Termos como dialética, ciência, desenvolvimento, sistema, substância e sujeito são termos que perfazem uma sistematização conceitual de remissão interna constante na obra de Hegel. Para que se possa compreender qualquer um dos termos é necessário compreender o outro, uma vez que eles sempre o evocam. Assim, por exemplo, podemos pensar, já com esses termos aclarados, que o percurso de substância a sujeito é o desenvolvimento dialético desta, o que significa que é, portanto, a exposição científica do sistema. Tudo isso só pode ser assim pensado na medida em que é exposto para um indivíduo capaz de apreender essa exposição, mas, mais do que simplesmente apreender, acompanha-la, no sentido forte dessa metáfora, i.e, caminhar em conjunto. ${ }^{165}$ Essa pressuposição, Hegel a faz pelo simples fato de que seus possíveis leitores compartilham com ele a época e, portanto, sendo eles parte do mesmo espírito do tempo, serão capazes de compreender sua exposição.

164 Dizemos "boa parte" e não "todos” porque já demonstramos como é possível arguir, por exemplo, que a Lógica, apesar de pressupor o Espírito, pode vir antes dele e de seu desenvolvimento, como foi o caso na Enciclopédia. GADAMER, 2012.

${ }^{165}$ HEGEL, 1992, p.35. 
Mas tal caminhar tem ainda um outro pressuposto, que é justamente o acúmulo de saber não aclarado na história do Espírito, como se cada consciência moderna (que é também o Espírito, já que ele é delas composto ${ }^{166}$ ) já tivesse guardada em si o resultado do acúmulo dessa história, sem nunca a passar a limpo. A tarefa da Fenomenologia, nesse sentido, é justo fazer com que a consciência possa percorrer

"esse passado da mesma maneira como quem se apresta a adquirir uma ciência superior, percorre os conhecimentos-preparatórios que há muito tem dentro de si, para fazer seu conteúdo presente; evoca de novo sua rememoração, sem, no entanto, ter ali seu interesse em demorar-se neles. O singular deve também percorrer os degraus-deformação-cultural do espírito universal, conforme seu conteúdo; porém, como figuras já depositadas pelo espírito, como plataformas de um caminho já preparado e aplainado."167

O percurso, portanto, é aquele da compreensão daquilo que ocorreu, do passado já vivido, na medida em que esse passado não deixa nunca de se inscrever e de causar seus efeitos, não perde sua capacidade de atuação. Em uma palavra, o passado não apenas existe, como insiste. $\mathrm{O}$ tom aparentemente psicanalítico ${ }^{168}$ da fórmula se dissolve se pensarmos bem no contexto geral e na amplitude do movimento hegeliano: não se trata de uma história pessoal a ser rememorada ou ab-reagida, fazendo o indivíduo passar por todas as inversões e interversões que o marcaram; antes, trata-se de rememorar a maneira como a constituição de uma época como a presente é tributária da morte e da sucessão de épocas. A ênfase, aqui, é na morte e não tanto na ascensão da próxima etapa, posto que será ela que colocará, constantemente, as coisas em movimento $^{169}$. Não será caso, aqui, de contar uma história filosófica com vistas a refletir acerca do surgimento da época presente tal e qual tal o surgimento se deu; antes, será caso de refletir acerca das sucessivas mortes que foram necessárias para que a época presente surgisse, posto que tais mortes desvelam o sentido e a direção do

${ }^{166}$ BEISER, 2012. Bem verdade que Beiser exclui, desse livro específico, Hegel. Igualmente verdade que sua leitura desses autores, por mais que critique Hegel, é profundamente hegeliana.

${ }^{167}$ HEGEL, 1992, p.36.

${ }^{168}$ É lugar comum na psicanálise lacaniana dizer que coisas como "o inconsciente não existe, mas insiste", querendo isso dizer que seu caráter não é o de uma transcendência de si rumo a um projeto (Sartre), mas de uma insistência infinita em busca de escuta. Não por acaso, cremos: Lacan foi um dos muitos a frequentar as aulas de Kojève sobre Hegel e, a partir dela, dialetizou boa parte da psicanálise. No texto, esposamos uma noção freudiana por motivos de simplicidade.

${ }^{169}$ Daí frases como "as épocas de paz são as folhas em branco da história". 
movimento do Espírito, bem como trazem à tona o campo dentro do qual se poderá falar de mudanças em concepções diversas. Não é que o surgimento não seja contado: ele simplesmente não é tido como o ponto no qual recai a luz maior. A morte e o luto não são negações totais ou abstratas, mas geram a novidade: eis uma das inovações hegelianas.

Existe aí, é claro, uma questão de pressuposto filosófico. Se o verdadeiro é o Todo $^{170}$ e o todo só se pode pensar a partir de seu desenvolvimento, quando a história do mundo for pensada pelo filósofo, ela precisará sê-lo de modo que o que era temporal se torne lógico. Dito de outra maneira, o que ocorreu ao acaso, fruto das paixões dos homens, precisará ser visto como algo que se passou por motivos relativos ao desenvolvimento de um determinado aspecto fundamental à época de quem fala. $\mathrm{O}$ presente, enquanto futuro do pretérito, ilumina essa época e permite que certas dimensões do passado ganhem luz e contorno o que, à época, era rigorosamente impossível pela própria lógica inerente ao processo de desenvolvimento. O tempo deixa de ser então, meramente acaso e contingência que ocorre em um espaço, deixamos de poder falar dele como numa cronometria e entramos no reino de uma cronologia, amarrada pelo desenvolvimento daquilo que se busca. É assim que se pode falar que existe a construção de um todo a partir do seu desenvolvimento: aquilo que se desenvolve, circunscreve e amarra uma série dispersa numa unidade coesa não por mera força do entendimento, mas pela passagem mesma do tempo e pela sucessão dos eventos, o que permite a significação do que já foi como um necessário a posteriori.

Por esse viés, uma afirmação como a seguinte se torna ainda mais clara do que antes:

Entre as várias consequências decorrentes do que foi dito, pode-se ressaltar esta: que o saber só é efetivo - e só pode ser exposto - como ciência ou como sistema. Outra consequência é que, uma assim chamada proposição fundamental (ou princípio) da filosofia, se é verdadeira, já por isso é também falsa, à medida que é somente proposição fundamental ou princípio. Por isso é fácil refutá-la. ${ }^{171}$

Considerando que a proposição fundamental opera num duplo registro, "logicizando" a realidade efetiva e traduzindo-a em termos conceituais, a refutação se

\footnotetext{
${ }^{170}$ HEGEL, 1992, p.31.

${ }^{171}$ HEGEL, 1992, p.33.
} 
torna o meio do desdobramento da própria realidade porque ela é o espelho lógico da passagem do tempo presente. Daí que os conceitos de Hegel tenham um certo eco temporal e que seu sistema seja um sistema no qual o movimento caiba: não é um Todo acabado aquele sobre o qual Hegel teoriza, tampouco é um Todo apartado da temporalidade ou imerso na eternidade, mas é um Todo que ou positiva o presente e exclui a contingência ou pensa a formação quando na concreção pensa. Nos dois casos, o movimento do pensamento, da lógica do pensar, é precisamente aquele da lógica da exposição.

Não é à toa que Hegel faz história da filosofia e a tem no mais alto grau de ensino filosófico ${ }^{172}$, considerando ser ela o caminho para a formação filosófica ${ }^{173}$ : desde o ponto de vista de uma história filosófica da humanidade, trata-se de pensar o porquê de determinados conceitos se modificarem, de determinadas relações serem pensadas de formas diversas de outrora ou, em suma, se trata de pensar o que ocorre com o Espírito em sua marcha para que seja possível e concebível um pensamento que não mais reflete sobre o cidade como realização do homem (Grécia), mas sim como um grande monstro que é violento com todos e monopoliza a violência (o Estado em Hobbes). A pergunta a ser feita não é tanto acerca das influências pessoais de Hobbes - como a história na qual relata ter tido por irmão gêmeo o medo -, mas sim uma pergunta de abrangência maior: quais são as condições de possibilidade históricas para que um tal conceito seja produzido e tenha ressonâncias? O que muda, no Espírito, de Platão a Hobbes?

O eco da filosofia transcendental kantiana, obviamente, não é ocasional. Se a filosofia de Kant buscava, em grande parte, as condições de possibilidade do conhecimento racional na própria razão, sem considerar o horizonte histórico dentro do qual essa mesma razão se estrutura, Hegel buscará retificar isso e mostrar que mesmo a pergunta pelas condições de possibilidade do conhecimento já depende de um contexto histórico dentro do qual ela faça sentido ${ }^{174}$.

172 Cf. os momentos da Propedêutica nos quais Hegel exorta abertamente o ensino de filosofia e diz que ensinar a filosofar em detrimento do ensino de filosofia é como um passeio em cidades no qual se visita o chafariz e pensa, com isso, ter visitado a cidade. HEGEL

${ }^{173}$ HEGEL, 2018, p.383.

${ }^{174}$ LONGUENESSE, 2016. 
Importante separar, aqui, histórico de puramente empírico. Se o Espírito caminha, avança, marcha, ele não o faz nunca obedecendo leis prévias, obedecendo algo que fatalmente iria acontecer. Ele por vezes também recua, ele também se repete, ele também retifica certos momentos e destrói outros. É apenas posteriormente que se saberá se aquela alteração nele será algo duradouro ou não. É o que Lebrun aponta muito bem ao dizer que o Espírito muitas das vezes aprende com a história ${ }^{175}$. É igualmente esse o sentido de afirmar que o "sucessivo desaparecimento dos impérios, e não o quadro de sua sucessão" são os temas da história ${ }^{176}$. Isso é marcadamente diferente do reino da pura empiria, por Hegel identificada como sendo situado na natureza. Afinal, na natureza "a sucessão de figuras orgânicas somente pode ser articulada por um "movimento contingente", ou seja, "as variedades de uma espécie poderiam ser outras, ou mais numerosas" $" 177$.

Vai daí, então, que o contexto da história precise ser pensado duplamente: por um lado, como a contingencia que a faz passar na outra, que faz Roma eliminar Grécia, etc. por outro, como a significação, na história do mundo, dessa mesma eliminação, essa sim capaz de gerar história. Outra forma de dizer que a necessidade é pensada como profundamente aterrada à contingência ${ }^{178}$. O contexto histórico, nesse sentido, se assenta numa paradoxal contingência necessária a posteriori, posto que toda necessidade vai ser ressignificada como sendo algo apenas apreensível no fim do processo.

Com isso em mente, podemos pensar que o escândalo kantiano ${ }^{179}$, i.e., o fato de Kant descobrir que a filosofia é culpada de não ter justificado o mundo de maneira racional, só é realmente um escândalo para alguém que não vê o aprofundamento da preponderância do conhecimento racional como algo historicamente situado, i.e., alguém que não vê que sua época é justo mais esclarecida (no sentido de ter mais influência do Iluminismo, sem qualquer juízo moral nesse caso) do que a época cartesiana. É um escândalo apenas para quem pensa ahistoricamente acerca do

\footnotetext{
${ }^{175}$ LEBRUN, 1988, p. 22.

${ }^{176}$ Ibid, idem.

${ }^{177}$ Ibid, idem.

178 ZIZEK, 2012, p.98.

${ }^{179}$ Não confundir com escândalo da filosofia kantiana, ou seja, tratamos aqui do problema que
} Kant levanta como escândalo. 
conhecimento. E isso a despeito de ter sido de Kant um dos primeiros textos sobre a história.

Mas, vejamos que curiosa virada nós demos aqui: começamos, há algumas páginas, a nos perguntar sobre a fundamentação da filosofia hegeliana ou, antes, sobre o que significa fundar em Hegel. Nossa expectativa era a de que, encontrando um fundamento, um princípio, um start que fosse, encontraríamos também um critério seguro a partir do qual poderíamos falar em formação. Afinal, para nos sabermos formados, bastaria que entendêssemos a realidade desde aquele ponto de vista, bastaria que apreendêssemos o ponto um a partir do qual todos os outros se seguiriam. Ser formado significaria, então, ser capaz de apreender a cadeia causal desde o seu princípio até seu final, o princípio sendo o mais importante por ser o ponto do qual partiríamos.

No entanto, só conseguimos como resposta o fato de que o fundamento é sempre um grande negativo que mantém o movimento e a partir dele determina o objeto, sem nunca ser um fundo definitivo ou um axioma que se assume a despeito da possibilidade de sua demonstração. Vale aqui o que Dieter Henrich sintetizou bem ao afirmar que "Hegel nunca desenvolveu um discurso secundário que interpretasse o que estava fazendo" ${ }^{180}$. Outros dois modos de dizer a mesma coisa: não há metafilosofia em Hegel porque é tudo metafilosófico e filosófico ao mesmo tempo; ou ainda, não há fora, porque Hegel fala da totalidade se compreendendo por dentro.

Isso nos parece apontar para um modo de filosofar que vai precisar reformular completamente o que se entende por linguagem filosófica, tendo em vista que a linguagem anterior foi simplesmente tida como insuficiente, i.e., uma fundamentação ao estilo "comum" teria uma proposição fundamental como base verdadeira, não como algo que é simultaneamente verdadeiro e falso. Tal reformulação, em Hegel, se fará ao nível da proposição: deixará de empregar o que chama de proposição raciocinante para empregar o que chamará de proposição especulativa, o que significa que deixará de pensar sem movimento e destruição a passará a partir deles, de modo que o desenvolvimento será necessário à construção filosófica ela mesma e o conteúdo por ela será informado. Uma tal proposição, que abrigue também o desenvolvimento, é a

${ }^{180}$ HENRICH, 2008, p.317 
única que consegue articular os termos movimento e totalidade e fazer desta última resultado do primeiro de maneira satisfatória.

Antes de irmos às diferenças entre proposição especulativa e raciocinante, no entanto, precisaremos compreender o que significa a introdução do negativo a partir da linguagem, porque será uma disputa em torno dessa negatividade o que estará em questão nessa sessão do Prefácio. Explicando melhor, existem pelo menos duas formas identificadas por Hegel de introduzir o negativo na linguagem: a primeira, é por uma espécie de fusão entre o cinismo moderno e o romantismo, o que diz muito mais sobre a apreensão que Hegel faz da filosofia romântica do que dos pressupostos e consequências da filosofia romântica se considerada sem a rivalidade de Hegel $^{181}$; outra é a sua própria, uma forma especulativa, que mesmo aos olhos de Hegel se difere em muito pouco da maneira como os românticos manejam a negatividade, razão pela qual a virulência de Hegel nos ataques precisa ser tão intensa ${ }^{182}$.

Todo caso, a diferenciação que Hegel promove é, sobretudo, uma diferenciação na dimensão ética e suas consequências no uso da linguagem. Nesse sentido, a linguagem mostra, para Hegel, uma certa posição frente ao mundo, ao conhecimento e às coisas posto que a linguagem é a única forma de demonstração da razão por ele aceita. Nesse sentido, antes de entender o que Hegel faz das proposições, é preciso que entendamos o que Hegel instila e/ou descobre na linguagem para que possamos entender como ele consegue construir as suas proposições especulativas. Nos usos que Hegel faz da linguagem no primeiro capítulo da Fenomenologia, bem como nas suas exposições acerca dela no terceiro volume da Enciclopédia, nos parece existir elementos para construir um caminho que podemos percorrer de modo a aclarar a diferença de consideração da linguagem que Hegel empreende em relação aos seus colegas.

Conforme dissemos na introdução, apesar de ser obra posterior, a concepção de linguagem hegeliana não parece ter se modificado da Fenomenologia até a Enciclopédia, se mantendo, nesse sentido, uma constante. Tanto o capítulo um quanto

${ }^{181}$ SAFATLE, 2017.

${ }^{182}$ Ibid, idem. 
o seis $^{183}$ da Fenomenologia refletem precisamente a concepção de linguagem explicitada na Enciclopédia. Outra coisa que ambos têm em comum é o fato de atrelarem questões referentes à linguagem e à designação à figura do sujeito designante, bem como às impossibilidades de dizer o tempo presente. Dito de outro modo, parece ser impossível a Hegel falar da linguagem sem falar do Eu que a enuncia e colocá-lo, também ele, em questão, junto à posição de linguagem por ele anunciada e à alocação temporal por ele pressuposta. Parece ser um modo de dizer que é impossível conceber uma noção sobre a linguagem e um uso decorrente desta que não pressuponha já uma noção de sujeito subjacente. Parece ser também uma maneira de barrar as tentativas de falar no presente sobre o presente, como se a própria linguagem, por ser uma "coisa" também ela, já estivesse deslocando aquilo de que se fala do lugar. Essa nos parece ser outra forma de dizer, como já foi dito por outro comentador, que Hegel foi o primeiro filósofo sistemático a levar a sério as ponderações de Herder em seu Ensaio sobre a origem da linguagem ${ }^{184}$.

\subsection{A linguagem na Fenomenologia}

O primeiro passo para a compreensão da linguagem em Hegel, ou melhor, para entendermos as posições que ela ocupa ao longo da Fenomenologia do Espírito e das outras obras é o de tentar compreender como ela é utilizada de uma maneira tríplice: como introdução do negativo, como um comportamento frente a esse mesmo negativo, e como exposição da própria filosofia hegeliana. Sobre este último aspecto, emitiremos uma reflexão detida de nosso punho, posto que vemos tal aspecto como coincidente com a execução da obra. Esse o motivo pelo qual, ressaltamos ainda uma vez, se faz desnecessária uma reflexão sobre a linguagem de maneira a cristalizá-la em um conceito ou uma seção própria de sua obra. Como Koyré bem observa

"Ele [Hegel] pode criticar o mau uso da linguagem - o de seus contemporâneos, não a própria linguagem. A linguagem - palavra e

183 O capítulo seis da referida obra será fundamental para compreendermos o lugar da proposição especulativa e sua dinâmica de funcionamento em relação à raciocinante e, por isso, será explorado posteriormente.

184 TAYLOR, 1999, p.19. 
pensamento, sermo e verbum, é realidade espiritual. A linguagem pode ser abstrata, doente e até morrer. Mas isso porque o espírito (a forma particular, Gestalt, do espírito) é abstrato, doente e morre. A história da língua, a vida da língua, é ao mesmo tempo a história e a vida do espírito" 185

Dito isso, na pena de Hegel, a linguagem sempre vai operar esse papel triplice, ora de maneira explícita, ora de maneira implícita. Na situação que destacamos aqui, dois casos (introdução do negativo, denotação de um comportamento) estarão presentes de forma clara.

Nosso trecho escolhido é o do capítulo um, acerca da certeza sensível. É uma bem conhecida passagem da obra de Hegel, posto que recebeu generosa atenção dos comentadores ao longo do tempo ${ }^{186}$. Como se sabe, Hegel está tentando fazer com que a consciência se dê conta de que a certeza sensível que ela tem dos objetos com os quais se encontra não consegue dar conta de expressar a sua verdade, porque os atos intencionais nessa direção falham no momento mesmo de sua realização. A tentativa de realização é, ela mesma, o passaporte para o fracasso da consciência de realizar seu conhecimento, o que coloca em movimento toda a educação e formação para o negativo pelo negativo.

Assim, no começo do capítulo, a certeza sensível se crê "sendo o conhecimento mais rico" e sem contextos ou determinidades que a delimitem ${ }^{187}$. Em suma, crê conhecer a essência do objeto, seu em si e poder expressá-lo de maneira não determinada. Não obstante isso, crê que as relações que têm com os objetos são relações entre uma "consciência, Eu, este" e uma "Coisa, isto" 188 e que elas são as de puro conhecimento independente, uma espécie de acesso imediato e total àquilo que visa. A ausência de mediação, ou seja, a imediatez, é o que marca essa relação, razão pela qual ela se crê a maior e mais pura e também a mais ilimitada: se não há nada que se interponha entre a coisa e eu mesmo, se o mutismo da intuição direta se impõe, logo, a relação é imperturbada e eu apreendo, com isso a verdade. Ao menos é isso que a consciência, nesse estágio, pensa. Aqui a indeterminação oriunda da falta de mediações

${ }^{185}$ KOYRÉ, 2011, p. 204.

${ }^{186}$ Para além daqueles que nos acompanham (Hyppolite, Gadamer, Safatle, Lebrun, Arantes) há também um longo comentário de Agamben sobre a referida seção que também utilizamos.

${ }^{187}$ HEGEL, 1992, p.74.

${ }^{188}$ Idem. 
é tomada por determinidade máxima e aquilo que é o mais universal é tomado como o mais singular. Não que seja tomada de maneira errônea: a realidade assim aparece à consciência, sem que exista quaisquer possibilidades de pensar de forma diferente da que se pensa.

Para que a consciência se aperceba da existência de um erro, Hegel toma dela seus pressupostos e busca tentar realiza-los na linguagem: "Nós não temos, para esse fim, de refletir sobre o objeto [posto que é certeza sensível], nem indagar o que possar ser em verdade; mas apenas de considera-lo como a certeza sensível o tem nela."189 Uma vez que a certeza sensível ainda não adota a reflexão, posto pra isso precisar ser capaz de se questionar sobre seus modos de apreensão do mundo e de interpor uma distância entre sua percepção do mundo e o próprio mundo, será a partir daí que procederemos. ${ }^{190} \mathrm{O}$ fato de ela ainda não realizar uma reflexão nos compele a fazer com que ela simplesmente se expresse sem, com isso, se questionar. Estamos jogando o jogo no nível dela, por assim dizer.

Como expediente para explicitar o erro no saber da certeza sensível, Hegel recorrerá a duas definições precisas de tempo e espaço: aqui e agora. ${ }^{191}$ Tal escolha não é obviamente ocasional e tem três motivos. O primeiro é que "aqui" e "agora" são componentes diferentes, segundo Hegel, do termo isto, utilizado pela consciência para se referir às coisas singulares enquanto singulares, enquanto copresentes e enquanto contemporâneas do juízo efetuado. Quando a consciência da certeza sensível diz "isto", então, ela crê estar se referindo a um objeto específico localizado em uma coordenada espaço-temporal específica, objeto esse que é apreensível por ela. Estaria, com isso, se referindo a uma singularidade bem determinada, que em nada depende do contexto no

${ }^{189}$ HEGEL, 1992, p.76. Adição em colchetes nossa.

${ }^{190}$ Uma das etapas do procedimento hegeliano que se repetirá ao longo de todas as suas obras é justo a introdução de um segundo termo que serve de ponto para apresentar a contradição ao primeiro. Nesse sentido, aqui, é a consciência sendo contradita pelo "Para-nós", aqueles que perguntam à consciência sensível e pedem que ela explicite a sua experiência pela linguagem; ao longo das outras obras, a pergunta estará mais ou menos implícita, pois o desenvolvimento, enquanto condição para verdade, já será pressuposto, ao passo que aqui ele é demonstrado e explicitado de maneira direta. Não que toda a obra hegeliana e todas as suas demonstrações não se demorem justo em demonstrar o desenvolvimento da verdade e seu grau de importância para o conceito de verdade, mas que essa explicitação não se dê de maneira tão clara quanto aqui. Ou seja, para levar a termo a verdade na Fenomenologia, Hegel elabora uma díade, ao passo que a partir da Lógica será apenas a verdade se desenvolvendo e encontrando a diferença em seu caminho que encontraremos.

${ }^{191}$ HEGEL, 1992, p.75. 
qual é falada para existir. É, portanto, uma fala que descreve um em si do qual ela simplesmente fala de maneira certa e precisa: entre sua fala sobre o isto e o próprio isto existiria uma transparência absoluta, já que para ela o isto é o em si. Em outras palavras: não percebe que o que tem é um saber sobre o em-si ou, antes, que o em-si é um em-si para ela. Tanto assim que nos diz Hegel: "o conteúdo concreto da certeza sensível faz aparecer imediatamente essa certeza como o mais rico conhecimento e até como um conhecimento de riqueza infinda." 192

Analisando a metodologia hegeliana em comparação àquela da Lógica, bem como a posição por ele adotada aqui, podemos dizer que o imediato nesse primeiro capítulo tem certa complexidade, o que pode iludir o leitor que pra ela não se atenta ou que ainda não se iniciou na Ciência da Lógica. Estamos, como no capítulo sobre o Puro Ser na Ciência da Lógica, diante de um começo. Mas, diferente daquele livro, aqui se parte da realidade concreta, ao passo que lá se parte de um conhecimento logicamente anterior à realidade ${ }^{193} \mathrm{Ou}$, como já citamos, do conhecimento de Deus antes da concreção ${ }^{194}$. Assim, é como se a consciência ordinária apreendesse o objeto determinado como puro ser, mas falasse dele como um isto, quer dizer, existe uma confusão de não perceber que o Puro Ser é e somente é, sem ter quaisquer determinidades e que o isto não pode ser falado imediatamente. É como se a consciência tentasse falar de algo sem perceber a necessidade contextual implicada no que diz. O puro ser, no entanto, permite uma tal fala justo porque ele é a exata suspensão de contextos, ao menos na Lógica. ${ }^{195}$

O significado aí é claro: "ser" não pode ser o único atributo de algo existente na realidade efetiva, sob pena de passar ao Nada e ao Ser retornar, ou seja, de ser apenas devir ${ }^{196}$. Isso nos mostra ainda porque Hegel procede a partir da demonstração

192 HEGEL, 1992, p.74. Grifo do autor, negrito nosso.

${ }^{193}$ Daí Marcuse poder dizer que a História efetiva o que a Lógica traça antes da efetividade, ou seja, antes da história tornada lógica.

${ }^{194}$ HEGEL, 2016, p.52. Para uma retomada do trecho completo, cf. pg. 27 da tese.

195 Pode-se sempre arguir, como fez Gadamer, que mesmo o puro ser, na verdade já pressupõe uma compreensão linguística prévia do que são os termos naquela seção, de modo que não é tão puro ou tão início assim. Para sê-lo, pensa Gadamer, seria necessário que a linguagem se autoconstruísse sem recurso a nada externo. Mas e se a Lógica for apenas uma crítica da metafísica, como quer Loguenesse? Nesse caso, o uso das palavras em seu sentido corrente e suas redefinições se tornariam não erros, mas precondições da boa execução do trabalho.

196 HEGEL lógica puro ser. Não é por acaso que, nas duas obras, o imediato seja apresentado de maneiras tão distintas: na Fenomenologia - antessala da Lógica, lembremos - a consciência já se deu 
de que a fala da consciência acerca do isto nada mais é do que a tentativa fracassada de apreensão desse devir a partir da linguagem: tudo se passa como se, ao tentar apreender o isto como sendo o mais essencial ele se dissolvesse justo porque ele não é outra coisa que esse desvanecer-se, ou seja, esse puro devir.

Assim, a coisa aparece para a certeza sensível dessa maneira sedimentada e abstrata, mas não é, por assim dizer, estanque nessa aparição. Eis aí um dos "segredos" de Hegel. Ao longo da Fenomenologia será sempre necessário um começo estanque para que Hegel seja capaz de demonstrar que mesmo nessa estabilidade aparente se esconde um movimento do qual a consciência não estava ciente, mas estava com ele contando. Seu desconhecimento não a torna errada, no sentido tradicional do termo, i.e., incapaz de apreender a verdade ou estando nas trevas e tendo de buscar um vocabulário que finalmente seria capaz de dizer a verdade ${ }^{197}$; ao contrário, sua falta de reconhecimento de seus pressupostos é também um dos momentos da verdade, mas é apenas um momento que não se compreende enquanto momento. Crê-se estagnado, como que repousando finalmente naquilo que há de mais rico e erra, curiosamente, por não errar. Como é próprio da certeza sensível conferir ao objeto uma substancialidade, não ocorre a ela que sua fala pode ter qualquer tipo de intervenção na construção do objeto, nem que pode haver uma separação entre aquilo de que se fala e a fala ou, em outros termos, entre palavra e coisa, entre falante e falado, etc. Para ela, seu papel enquanto falante é apenas o de descrição de um objeto singular e não tanto o de referenciar a partir de um saber que lhe é próprio: sua palavra está "colada" à coisa, é como se a própria coisa fosse, porque está imersa na linguagem e nas próprias representações, sem disso saber. Por isso, não consegue suspendê-los, nem observar aí o negativo que ela mesmo é. Vai daí que Hegel tenha o expediente de muitas das vezes, fazer com que a consciência se dê conta de que há algo com que contava para enunciar sua verdade, por mais que não soubesse. Com isso, seu terreno seguro se mostra movediço no sentido literal que esse termo tem: algo instável porque móvel, incapaz de manter uma estabilidade.

conta de que a mediação é a maneira pela qual seu pensamento se estrutura e se desdobra; na Lógica, será caso de saber como tal desdobramento se dá a partir das próprias categorias. Cf a esse respeito GADAMER.2012, pp.93-94.

${ }^{197}$ LEBRUN, 2000, p.83. 
Não é por outro motivo que ela acaba sendo apresentada, já num segundo momento, como aquela que também separa, ainda que de maneira precária, o conhecimento entre o objeto verdadeiro e o eu cognoscente, sem fazer intervir a dúvida sobre o saber adquirido, ou seja, sem que o fato de que exista um sujeito cognoscente que diz Eu seja capaz de interpor quaisquer dúvidas sobre o objeto. Uma forma sucinta de dizer isso é afirmar que essa consciência ordinária é pré crítica e pré cartesiana, sendo por isso incapaz de conceber os objetos por ela observados como sendo por ela construídos. Daí porque

na certeza sensível, um momento é posto como o essente simples e imediato, ou como a essência: o objeto. O outro momento, porém, é posto como o insessencial e o mediatizado, momento que nisso não é em-si, mas por meio de um Outro: O Eu,um saber, que sabe o objeto porque ele; saber que pode ser ou não. Mas o objeto é o verdadeiro e a essência: ele é, tanto faz que seja conhecido ou não. Permanece mesmo não sendo conhecido - enquanto o saber não é, se o objeto não é ${ }^{198}$

Uma vez que a coisa é e isso se dá de maneira essencial para a certeza sensível, se torna impossível pensar numa relação entre sujeito e objeto na qual o primeiro tenha importância na maneira como o segundo aparece. O objeto existe por si só tal e qual ele é em si e, por isso, ele ou se dá a conhecer em sua inteireza ou é de todo opaco e impenetrável. Assim: "esse puro ser, ou essa imediatez simples, constitui sua verdade [da certeza sensível]. A certeza igualmente, enquanto relação, é pura relação imediata"199. Ainda um outro sentido para imediatez: porque está tão certa da consistência do objeto que não vê sua participação como algo existente, crendo bastar a utilização de termos corretos para a descrição que deseja realizar acerca da existência do objeto, a consciência não percebe o tanto de mediação que já faz intervir na sua relação com o objeto. Esse o segundo motivo do porquê de a escolha de aqui e agora ser importante: é a partir da quebra do isto nesses dois momentos que o compõe que a verdade contraditória de sua existência poderá ser mostrada, já que "aqui" e "agora" são determinações específicas de lugar e tempo que se desvanecem tão logo chegam a existir, o mesmo ocorrendo com o isto.

\footnotetext{
${ }^{198}$ HEGEL 1992, p.75, grifos do autor, negrito nosso.

199 Idem.
} 
O problema, aqui, é obviamente o problema do conhecimento e da existência e necessidade de práticas que são fundantes e fundamentais à atividade de conhecer. Pinkard delineia bem a questão: "se há algum conhecimento que é independente de prática social ou histórica, então o conhecimento imediato deve sê-lo" ${ }^{200}$. Note-se aqui, então, as mediações que Pinkard já auxilia a antecipar quando se coloca a questão pelo seu ângulo - embora ainda não faça a mediação da linguagem comparecer: sociedade, história e, adicionemos, linguagem, são as outras dimensões constituintes de todo o processo de conhecimento que, aparentemente, a consciência simplesmente ignora ao realmente acreditar que pode conhecer algo imediatamente.

Aqui, ainda uma outra faceta do problema: a realidade concreta não se deixa ver por suspensão de sua materialidade, i.e. uma abstração ou uma reificação do objeto somente falseiam a realidade. Por contraponto, pensemos em como a Lógica de Hegel trabalha com uma suspensão da realidade efetiva, posto que é um constructo racional sistemático que busca a estrutura do real e da metafísica. Nesse sentido parece-nos impossível não concordar com Longuenesse e com Lebrun, já que para ambos a Lógica hegeliana é uma crítica da metafísica ${ }^{201}$.

Retornando aos termos "isto", "agora" e "aqui", é importante situarmos um aspecto contemporâneo da discussão, i.e. um aspecto no qual temos um esclarecimento contemporâneo a partir da linguística. Na linguística contemporânea, termos como aqui, agora, isto, Eu, etc, são conhecidos como shifters ou dêiticos e são palavras referenciais que são tão enraizadas no contexto em que se encontram que só fazem sentido dentro deles ${ }^{202}$. Mais do que isso: são termos que criam uma série contextual interdependente e interreferente, i.e. um agora já põe em jogo um depois e um antes, mas também um aqui e um Eu e assim sucessivamente ${ }^{203}$. Quando digo aqui ou agora, estou situando uma série de coisas dentro de um contexto: minha posição atual no espaço é a referência a partir da qual falo, então o aqui cria, por seu uso, um acolá e um lá; minha posição no tempo é a referência que uso, então esse instante do agora cria um

${ }^{200}$ PINKARD, 1996, p.23.

${ }^{201}$ LEBRUN, 2000; LONGUENESSE, 2007.

${ }^{202}$ Para uma discussão sobre dêiticos e Hegel, CF. ARANTES, 1996, p.388. Para uma discussão densa, oriunda da própria linguística, BENVENISTE, 1968.

${ }^{203}$ Idem. 
outrora, um antes e um depois; e assim sucessivamente, para todos os termos dessa natureza.

À época de Hegel, a discussão da linguística ainda não estava presente como a conhecemos hoje, mas são propriedades desses shifters que Hegel acaba utilizando ao falar de aqui e agora e pedir que a consciência seja capaz de manter a verdade do saber sobre seu objeto da qual ela está certa. Pela natureza relacional desses termos, a manutenção da sua verdade no tempo, algo que Hegel diz ser possível se algo for de fato verdade ${ }^{204}$, é impossível. Especialmente em termos como agora, a verdade dura tão pouco quanto o tempo de proferir o último fonema, pois o instante já passa tão logo a o fim da palavra é proferido, tornando o referente inatingível. É justo pedindo à consciência que defina de maneira certa e definitiva o que é o agora, conferindo verdade ao saber que ela crê possuir, que Hegel desbanca a tal certeza a partir da impossibilidade de sua realização que é percebida a partir da tentativa. Assim,

"à pergunta: o que é o agora respondemos, por exemplo: o agora é a noite. Para tirar a prova dessa certeza sensível, basta uma experiência simples. Anotamos por escrito essa verdade. Uma verdade nada perde por ser anotada, nem tampouco porque a guardamos. Vejamos de novo, agora, neste meio-dia, a verdade anotada; devemos dizer, então, que se tornou vazia." 205

Aqui, nesse primeiro momento do primeiro capítulo, é onde vemos que na tentativa de proferir a verdade da qual está certa a consciência acabar por errar e desbancar a sua certeza ${ }^{206}$; isso, por seu turno, abre espaço para uma marcha em direção à outra forma de apreensão da realidade de modo que se dê conta da existência de processos de mediação envolvidos naquilo que inicialmente se julgava imediato. A certeza que existia era a de que os objetos existiam por si só e eram apreendidos de maneira imediata. Mas no caso da designação agora, a mera tentativa de referir precisa contar com uma série de mediações para estar correta e isso força a consciência a reconhecer que seu saber sobre o objeto já está imerso numa teia de mediações da qual ela não está ciente. Isso porque, uma vez que é contextual, o agora pode se referir tanto

\footnotetext{
${ }^{204}$ HEGEL, 1992, p.76

205 Idem.

${ }^{206}$ HYPOLLITE, 1974, p.85.
} 
ao meio dia quanto à meia noite a depender de quando é lido; o mesmo termo é capaz de se referir a dois momentos distintos, o que prova que ele não possui uma verdade substancial e estática, mas uma verdade mediada, ou ainda, que sua verdade é oriunda e dependente do contexto no qual é falado. Foi esse mesmo contexto que foi recusado pela consciência logo no início e sua assunção faz com que seu saber deixe de ser o mais rico para ser o mais pobre. ${ }^{207}$

A passagem também é importante porque marca também o primeiro contato da consciência com o negativo. Isso se expressa de maneira mais direta, ainda nas palavras de Hegel: "o agora que é noite foi conservado (...) mas se mostra como um não-essente (...) Também em relação ao dia que é agora, ele se mantém como um agora que não é dia, ou seja, mantém como um negativo em geral". ${ }^{208}$ Uma vez que não pode mais expressar aquela noite, a palavra agora se torna o negativo tanto do dia que agora teria de expressar e não o faz, quanto da própria noite que expressava outrora, mas que já se foi (daí negativo em geral). Ela se conserva unicamente na medida em que precisa mudar o que poderíamos chamar de referente. Nesse conservar-se que se dá com a modificação do referente, a consciência mostra que sua realidade não é substancial, mas contextual o que, em hegelianês, significa dizer que a verdade aí exposta não é o singular determinado e imediato que se pressupunha, mas um universal ou uma simplicidade mediatizada ${ }^{209}$. É essa a verdade que se mostra à certeza sensível nesse primeiro momento e, não obstante se mostrar no agora, se mostrará também no outro termo, o aqui.

Para demonstrar a mesma coisa também em relação ao espaço, Hegel situa a consciência frente a uma árvore. Assim, o aqui, no momento em que é proferida a sentença, é de fato uma árvore, mas ao virar-se, pode ser uma casa, uma colina ou quaisquer outras coisas. ${ }^{210}$ Tal como o agora que o precedeu, o aqui se mantém o que era outrora, ou seja, ainda se grafa do mesmo jeito e significa a mesma coisa, mas para isso precisa abdicar do seu referente universal. Também ele se torna um universal ${ }^{211}$.

\footnotetext{
${ }^{207}$ HEGEL, 1992, p.74.

${ }^{208}$ HEGEL, 1992, p.76.

${ }^{209}$ HEGEL, 1992, p.77.

${ }^{210}$ HEGEL, 1992, p.77.

${ }^{211}$ Idem.
} 
A passagem do tempo bem como a mudança no espaço e as consequentes mudanças de referências fazem ver que o agora e o aqui, enquanto saberes mais ricos, não se sustentam; no momento exato de sua realização enquanto verdade essencial, eles falham e se veem enredados pelo contexto. Essa é outra forma de dizer que o contexto sobredetermina as relações de linguagem e, além disso, a linguagem sempre diz mais do que a intenção inicial do sujeito é capaz de prever ${ }^{212}$. A consciência, neste primeiro capítulo, ainda não compreende que sua posição é impossível de se realizar porque ainda toma como dada a relação entre o fato de designar, a linguagem utilizada para isso e o objeto a que designa, como se a linguagem utilizada e o objeto a ser designado estivessem numa relação natural, o que não é o caso.

Com isso nos aparece o terceiro motivo pelo qual a escolha de aqui e agora serem importantes. Por serem apontados como componentes do termo isto, são também caminhos para a refutação do que se pressupõe quando se diz tal palavra. Uma vez que os componentes se mostram como negativos em geral, o próprio termo que deles se compõe (isto) não pode ser o que se supunha no princípio. Também ele deve ser um universal, uma vez que é precisamente a essa definição que um dos seus termos componentes, "agora", chegou. O universal, assim, é aquilo que é pensado como aplicável a qualquer contexto, uma vez que é um negativo que se realiza apenas pontualmente, sem nunca se realizar por inteiro em momento preciso nenhum.

Ao se dar conta da sua incapacidade de manter a posição inicial, a consciência rapidamente se desfaz de sua posição inicial na qual a coisa era o essencial e passa a colocar a si mesma como sendo o que existe de garantidor da verdade: "o agora é dia porque Eu o vejo; o aqui é uma árvore pelo mesmo motivo." ${ }^{213} \mathrm{O}$ que parecia uma astúcia na verdade se mostra como sendo uma recorrência do erro sob outra perspectiva. Aparece aí a perspectiva que a consciência está adotando em relação à compreensão que faz do que é o "Eu" que comparece em sua sentença. Ao voltar-se para o Eu, ela não apenas se mostra prisioneira de outro termo da categoria dos shifters, como igualmente revela que seu conceito de sujeito subjacente é um tal que pressupõe ser possível uma referência direta às coisas, sem que este esteja marcado por uma

${ }^{212}$ Cf. para uma discussão detida disso, SAFATLE, 2016.

${ }^{213}$ HEGEL, 1992, p.77, grifo do autor, negrito nosso. 
impossibilidade fundamental inerente ao próprio fato linguístico. É como se ela acreditasse que ao situar em si mesma a verdade da designação, ela não estivesse mais designando, mas apenas proferindo verdades.

Com efeito, como já dissemos, quando digo eu, situo imediatamente um tu, um ele, uma possibilidade de nós e assim sucessivamente. Mas pela característica universal e inicialmente indiferenciada do termo, quaisquer falantes podem proferir o termo eu e, como ambos os termos possuem a mesma validade, podem definir pontos de vista distintos para a mesma coisa. É assim porque para todos está dada a mesma possibilidade de uso linguístico desde sempre, sem que haja prevalência de um ponto de vista sobre outro. Isso mina quaisquer possibilidades de a consciência poder falar em singularidade, salvo uma: se recusar à comparação de instantes e posições à qual foi submetida previamente. Conforme nos diz Hegel, essa consciência "não quer mais dar um passo em nossa direção" 214 então nós é que vamos até ela e pedimos que ela nos faça uma indicação qualquer sobre suas verdades.

Redobrando o esforço, ela passa a dizer que é "esse aqui" e "esse agora" aqueles aos quais ela se refere. Mas o desvanecer no tempo é a verdade dos termos escolhidos, conforme dissemos acima e, pior: no momento em que se tenta referir ao instante passado, e.g. "estava falando do agora de antes", esse passado já passou ainda mais e essa frase já não guarda em si verdade nenhuma pois quando "suprassumo o ser-quefoi ou o ser-suprassumindo - a segunda verdade; nego, com isso, a negação do agora e retorno à primeira afirmação de que o agora é."215

Todo esse excurso demonstra que a consciência estava certa da existência de uma estabilidade, mas via esta ruir no momento em que tentava pô-la em linguagem que, se nos lembrarmos bem, foi eleita como a única via de demonstração do pensamento verdadeiro. Ora, se "o mais verdadeiro é a linguagem" é justo porque "nela refutamos imediatamente nosso intencionar (meinen) ${ }^{, 216}$. Nessa crítica imanente, a

\footnotetext{
214 HEGEL, 1992, p.79.

215 Idem.
}

${ }^{216}$ HEGEL, 1992, p.76. A tradução brasileira utiliza o termo visar que guarda uma relação muito fraca com a noção de intenção e implicação pessoal que meinen possui. Se pergunto "Was meinen sie?" é o mesmo que perguntar "o que você acha/pensa?" e não traduziríamos por "o que você visa?" porque seria uma tradução deveras distante do original. Do mesmo modo, quando digo "das will ich meinen", estou dizendo "era o que queria dizer" e não "era o que visava" porque "dizer" e a musicalidade da voz ficam de todo suprimidos. No sentido que Hegel o emprega, meinen tem essa noção de 
consciência vislumbra que "o falar tem a natureza divina de inverter imediatamente 0 intencionar, de torna-lo algo diverso, não o deixando aceder à palavra"217, ou seja, o uso da linguagem introduz um negativo e coloca a consciência num impasse: sem ela, ela não expressa sua verdade; com ela, tampouco o faz.

Importante notar que a impossibilidade de realização não é "notada", "percebida", "pensada", mas experimentada de dentro do processo mesmo que devia leva-lo a termo. A força impeditiva se faz sentir pela consciência no próprio processo que ela julga ser capaz de levar a termo. A efetivação do processo, sua passagem à realidade, parece trazer à luz uma contradição irremediável entre o que se intenciona e o que de fato de atinge. Outra forma de dizer isso é afirmar que uma experiência do impossível causa um desbalanceamento no campo dos atuais e possíveis. Um exemplo similar e mais contemporâneo pode nos ajudar aqui e pode nos demonstrar a complexidade da crítica de Hegel se aplicada a contextos outros que não aqueles puramente epistemológicos e, também, se feita ao seu reverso, ou seja, se uma consciência decide declinar do universal com o qual, no entanto, conta para a própria recusa.

O que faz com que essa contradição se apresente é a desconsideração da consciência do fato de que ela não é senhora de sua própria fala no momento em que a profere ou, nas palavras de Hegel, "Linguagem e trabalho são exteriorizações ( $\ddot{u}$ ßerungen) nas quais o indivíduo não se conserva mais e não se possui mais a si mesmo; se não que nessas exteriorizações faz o interior sair totalmente de si e o abandona a Outro" 218 .

Esse modo de situar a questão já conta com a alteridade em cada uso individual da linguagem, o que torna esta última uma ação social antes de qualquer coisa. Ademais, toma as palavras como coladas às coisas como um ato arbitrário. Isso faz com que uma crítica como a de Feuerbach, que toma o partido de como a consciência sensível experimenta os nomes, faça pouco ou nenhum sentido. Como a exposição e a

intencionalidade e de implicação subjetiva do "quis dizer isso". Numa dimensão poética/transcriadora, tem também menos a ver com a visão do que o termo português.

${ }^{217}$ HEGEL, 1992, p.82.

${ }^{218}$ HEGEL, 1992, p.198. Essa temática da exteriorização de si retornará de maneira mais detida quando falarmos de proposições especulativas, razão pela qual não nos aprofundamos nela ainda. 
resposta a essa crítica, especificamente, nos auxiliam a expor ainda um outro ponto da certeza sensível e da análise da linguagem hegeliana nessa etapa, nos serviremos desse expediente.

\title{
3.2.1. A Crítica de Feuerbach
}

Uma das primeiras coisas a se elucidar da crítica de Feuerbach é o juízo que ele profere acerca desse momento da obra hegeliana. Feuerbach critica Hegel por julgar que na passagem que Hegel faz do singular a um universal há algo de forçado, uma vez que ele desconsideraria o singular qua singular, preferindo trata-lo como universal de antemão. Poder-se-ia dizer que, para Feuerbach, não é estranho que Hegel encontre a universalidade na consciência sensível e sua consequente não adequação entre nome e coisa singular, pois ele mesmo lá a colocou e pressupôs para, durante uma grande atuação teatral, fingir-se de surpreso quando finalmente a reencontra ${ }^{219}$. A parte fundamental de sua crítica e a que mais nos interessa aqui, no entanto, se refere à sua tentativa de refutar justo o momento argumentativo da certeza sensível. Escreve Feuerbach:

\begin{abstract}
meu irmão se chama Johann, ou Adolf, mas há ainda inúmeros outros que existem além dele e que também se chamam, Johann, Adolf. Segue-se daí que meu Johann não é uma realidade, segue-se daí que a johannidade (Johannheit) é uma verdade? Para a consciência (Bewusstsein) sensível todas as palavras são nomes, nomina própria. ${ }^{220}$
\end{abstract}

A questão toda de Hegel não está ligada à existência empírica do singular apontado, nem tampouco à validade da afirmação estanque no tempo, como se dela tirássemos uma foto e perguntássemos se, de fato, aquele ali é Johann ou Adolf. Tampouco está preocupado Hegel com o que Feuerbach tenta apontar, a saber, que quando "nos viramos de costas a árvore ainda existe"221, ou seja, o problema de Hegel não está situado na existência ou permanência da realidade sensível, mas na apressada

\footnotetext{
${ }^{219}$ FEUERBACH, 2012, pp.40-45.

${ }^{220}$ FEUERBACH, 2012, p.46.

${ }^{221}$ Ibid, idem.
} 
adequação feita entre coisa e palavra, sentença e mundo, proposição e realidade exterior. Sim, tudo isto é verdade, as coisas continuam a existir no tempo: de fato ainda temos a árvore, ainda nos lembramos do dia e da noite etc; mas eles não são mais o “aqui” presente. Isso se dá precisamente porque o aqui é referencial e aponta para uma descrição universal de uma realidade singular, cuja marca maior é sua passagem tão logo a sentença é proferida. O problema não está na existência ou não da árvore por detrás do sujeito, mas na impossibilidade de nomear coisas singulares de maneira singular porque toda a língua é em si mesma um jogo de universais por sobre um singular inapreensível, a negatividade intrínseca à coisa de que fala Hege $l^{222}$

Por isso, quando Feuerbach tenta comparar um advérbio de lugar a um nome próprio (Johann/aqui), ele demonstra que não entendeu a compreensão exata de língua subjacente à filosofia hegeliana. Mais do que simplesmente apontar uma situação concreta descritiva, o que Hegel está apontando a partir do referido momento é a impossibilidade de descrição de singulares que a própria língua guarda em si mesma, posto que toda descrição precisa ser universal por excelência e, por isso, contextualizada para tocar o singular. Sendo assim, a reificação de uma proposição, por desconhecer esses pressupostos, acaba por errar o exato alvo que almeja abater.

Além disso, cabe ressaltar que o que Hegel opera na seção por nós lida é, também, uma repetição e um passo adiante na crítica à ideia de que o conceito seria apenas um agregador estanque de multiplicidades, crítica essa, como vimos, já feita no Prefácio. Isso se faz a partir da tentativa de levar as enunciações e as tentativas prévias de conceituar a termo e, curiosamente, ao serem levadas a termo elas desvanecem. "Ir ao fundamento é perder o fundamento" 223 , dirá Hegel anos cinco ano depois na Lógica, e é, num certo sentido, o que ocorre aqui: realizar a imediatez é perceber o necessário da mediação e o sem fundamento do imediato, ao menos nesse primeiro momento.

Por isso, o "aqui" ou o "agora" só se permitem compreender em suas verdades de universais no momento em que se devolve a eles o exato mesmo tempo de duração que Feuerbach visa retirar ao petrificá-lo em singularidade estática e atemporal, ao confundi-los, portanto, com um nome próprio. O procedimento de Hegel é devolver os

\footnotetext{
${ }^{222}$ HEGEL, 1992,

${ }^{223}$ HEGEL, 2017, p.85.
} 
termos aos seus contextos e radicalizar sua exposição para mostrar que a certeza está em discordância com a verdade fugidia de cada nomeação, shifters sendo a forma mais fácil de notar isso na linguagem. A discordância entre saber e verdade só se mostra assim, como não discordante, na hora que tenta melhor efetivar aquilo de que a consciência está segura. Existe um descompasso entre intenção e verdade, descompasso esse que é introduzido pelos usos da linguagem, de maneira irremediável. Dito de outro modo, para Hegel, entre objeto e linguagem não existe uma relação de complementaridade, mas de estranheza e o saber não reconhecido da certeza sensível evidencia isso de maneira direta.

Seguindo ainda a Feuerbach em sua crítica a Hegel, temos ainda um outro problema por ele levantado, a saber, aquele segundo o qual o "pensar" seria "prévio à exposição" 224 , i.e., é preciso que Hegel tenha materialmente pensado tudo o que pensou antes de escrever o que escreveu. Ora, uma tal dissociação entre pensamento e escrita ou entre sistema e pensamento ainda se mostra pré-hegeliana, vez que tenta dissociar o autor de sua obra e o pensamento de sua execução. É como se antes da escrita Hegel já tivesse concebido o sistema, de modo que a escrita seria apenas a transposição do jápensado e, portanto, apenas a realização material concreta do pensamento.

Hegel, nesse sentido, é bastante mais materialista ${ }^{225}$ e implica demonstração filosófica e existência de uma filosofia de maneira mais imbricada. Não existe sistema se ele não for exposto, justo porque as ideias privadas, sem sua exposição, de nada valem. Todo o excurso filosófico de Hegel contra a ideia de intuição, de algo que possa se saber no solitário quietismo ensimesmado, tem justo por consequência a junção entre pensar e expor. Aquilo que não se expõe, que não se permite expor, nesse sentido, sequer tem existência. É o exato oposto do que pensa Feuerbach ao dizer, por exemplo, que "na exposição, o começo é o primeiro apenas para ela, mas não para o pensar"226. Perguntando hegelianamente: se não existe pensar sem exposição, posto que a exposição é exatamente uma espécie de teste da correlação do pensamento com seus

${ }^{224}$ FEUERBACH, 2012, p.38.

${ }^{225}$ Nota pessoal: poder-se-ia arguir, como fez meu orientador e concordo, que todo idealismo possui uma face materialista, ao que subscrevo, adicionando apenas um marcador de intensidade: bastante materialista. Afinal, não é de Hegel a carta que Benjamin cita, na qual Hegel diria que ao dar o pão o reino dos céus viria?

${ }^{226}$ Ibid, idem. 
pressupostos (lembremos da certeza sensível), como situar dois começos distintos como pensar e expor? Como não relacionar um começo com o outro? Isso quer dizer que, num certo sentido, é o texto que pensa, não o autor. Este só vem a ser filósofo no momento em que efetiva, no papel, sua filosofia. Antes disso, apenas reflete sobre um tema de determinada maneira. Esta, uma das lições da formação hegeliana: entre exposição e totalidade vai uma relação de irmandade e copertinencia, não de contrariedade.

Tanto do ponto de vista do método quanto do ponto de vista da concepção de linguagem, as respostas de Hegel à crítica de Feuerbach já se mostram antes mesmo da crítica dele ocorrer. Isso porque Hegel constituiu seu sistema, conforme vimos, de modo que a refutação não seja simplesmente a destruição do sistema, mas sua continuação ou um retorno a ele em algum grau. Para que uma tal construção antecipativa fosse possível, preciso seria inscrever o negativo na demonstração, i.e. na linguagem filosófica, de modo que este fosse o leitmotiv do sistema. Isso a Enciclopédia pode nos ajudar a entender melhor, servindo aqui como uma espécie de comentário do próprio autor ao seu trabalho.

\subsubsection{Desvio I: linguagem como negatividade e universalidade}

Apesar de na Enciclopédia Hegel situar a linguagem na psicologia e, portanto, muito distante da seção fenomenologia que o livro possui, é impossível não notar que a concepção ali presente é a mesma que animava a Fenomenologia de 1807. É fácil confirmar o que propomos só de expor algumas partes. A título de exemplo, no adendo ao parágrafo 462 da obra, lemos a seguinte frase cujos termos ecoam alguns por nós exposto: "A palavra enquanto sonora desaparece no tempo; este assim se mostra na palavra como negatividade abstrata, isto é, apenas aniquilante. Mas a negatividade verdadeira, concreta do signo linguístico é a inteligência"227. Lembremos o que se passou na certeza sensível. O expediente de Hegel na Fenomenologia foi pedir que a consciência falasse o que é seu "aqui" e seu "agora". Assim que ela o faz, adentra um reino no qual se esvai o referente no momento em que tenta apreendê-lo. Nos termos

${ }^{227}$ HEGEL, 2017, p. 255. Itálicos do autor, negritos nossos. 
expostos, ela falha justo porque se põe na dimensão negativa abstrata inerente ao próprio ato de falar. Faz, portanto, sua localização no exato descompasso em relação ao referente. Grosso modo, o que ele afirma indiretamente é que é impossível falar de algo que se situa exclusivamente no presente porque a fala já possui uma durabilidade fugidia, vez que sua plena realização (o sentido) só se dá com sua morte (seu término, não há aquele sentido sem a frase completa). Isso é duplamente mais difícil com uma palavra como "agora", posto que ela vai buscar fazer referência a algo do qual ela mesma só pode ser a marca da ausência. Conjugando a fugacidade da fala com o referente para o qual ela aponta, Hegel constrói todo o seu capítulo da certeza sensível.

Será mais fácil de entender bem de que modo Hegel pôde conjugar esses termos, se soubermos como Hegel concebe a natureza daquilo mesmo que compõe linguagem, a saber, o signo linguístico. Hegel é bastante claro quanto ao signo e, a julgar por suas definições, antecipa boa parte das discussões acerca da arbitrariedade do signo que vimos no século XX a partir de Saussure. Senão, vejamos: "enquanto a representação universal, libertada do conteúdo da imagem, se tornou, em um material exterior arbitrariamente escolhido por ela, algo intuível, produziu assim o que se deve chamar de signo (Zeichen)"228. O signo, que nada compartilha com a imagem porque foi dela depurado e porque é algo pensado como arbitrário em relação ao seu referente, se torna algo acessível à consciência e passa a nomear, de maneira exterior, aquela imagem ali presente.

Feita a entrada do signo, toda vez que virmos o nome leão, pensaremos no grande felino dito ser o rei dos animais, embora entre o nome e o animal nada se passe. Não há qualquer necessidade regendo essa relação, mas ela é estabelecida no momento em que a nomeação se junta a outras nomeações e passa a se chamar linguagem. A necessidade, portanto, é igualmente retrospectiva aqui como na história: antes de nomear, podia possuir qualquer nome (lion, Löwe, raion, leon, etc.); agora que se sabe que é leão, é apenas a substituição de um signo (leão) por outro de outra língua que ocorre. A referência ao animal sem seu nome se torna impossível, constituindo algo que parece ser fundamental ao conhece deste. A necessidade aparece como se já sempre lá estivesse, mas a arbitrariedade do signo testemunha que não.

\footnotetext{
${ }^{228}$ HEGEL, 2017, p.246.
} 
O passo seguinte de Hegel será o de afirmar que o signo confere a qualquer coisa uma significação que lhe é estranha, (fremde, que também forma alienado, Entfremdung). A estranheza, aqui, não é qualquer estranheza; não se trata do estranho no sentido de algo que não se reconhece porque não se é familiarizado, mas do estranho no sentido de algo que em nada participa da essência do objeto ou imagem em questão. O signo, seja linguístico ou não, é absolutamente alienígena ao objeto que ele designa: não o expressa de maneira nenhuma, não o diz de nenhuma forma, é uma ação exclusivamente humana sobre uma matéria que é a ele estranho. Apesar disso, é somente a partir da realidade dos signos, i.e., da realidade significada por eles, que o humano pode compreender o mundo que o cerca, razão pela qual "se deve primeiro aprender a referência (Bedeutung) dos signos"229 para que se possa compreender a realidade. Ou seja, deve-se primeiro entender a que os signos se referem, a que outra realidade que não eles mesmos que eles apontam, para poder se tentar compreender qualquer coisa em sua inteireza.

Ora, se os signos se definem por apontarem, a partir de si, para uma outra coisa, resta claro que a operação, em termos mais metafísicos, é uma operação de negação. Uma outra forma de falar o que dissemos é dizer que o signo nega a sua própria materialidade e, a partir dessa negação e por causa dela, faz ver uma outra realidade que não a sua. A operação de negação é, nesse sentido, uma operação de negação determinada, posto que a materialidade do signo já estabelecido não vai ser negada para dar luz a quaisquer coisas num campo possível, mas a uma coisa específica que é dela dependente. A ligação intrínseca entre a sonoridade e a evocação de sentido é precisamente o que permite que a consciência evoque para si aquele ente e não outros, sendo um testemunho da importância da sonoridade aquilo a que chamamos entonação, capaz de modificar em absoluto o sentido de um signo pela simples alteração de ênfase de pronuncia.

${ }^{229}$ Ibid, idem. HEGEL, 2017, p.246. Mantive Bedeutung não apenas para aproveitar a discussão já proposta por Frege alguns anos depois de Hegel, mas também porque me parece que nesse primeiro momento, quando Hegel pensa os signos, ele indica primordialmente os signos que se mostram como ainda presos ao reino das representações. Parece-nos ser justo jogando com essa ideia de um grande sentido apoteótico e final que nunca vem de fato (já que tudo recomeça no fim, embora de maneira mediada), que Hegel constrói sua filosofia, de modo que postergar a entrega da referência para um além nunca alcançado parece fazer mais sentido do que postergar uma "significação" como o professor Paulo Meneses traduziu. 
O signo é, portanto, uma operação dupla de negatividade ou, se preferirmos, uma operação na qual a negatividade sempre circula. No momento em que ele é imposto à coisa, ele é uma operação de negatividade da inteligência por sobre a "representação simples da contingência"230; no momento no qual ele já está estabelecido, ele é uma operação de negatividade por sobre si mesmo para a recuperação desse material contingente em algum grau e é, também, uma manifestação das "representações da inteligência em um elemento exterior"231.

Note-se aqui que, nos dois casos, o signo nunca é, por si só, alguma coisa concreta ou existente, algo que possui uma concretude material que esteja dissociada de quaisquer realidades. Ele é sempre em relação negativa a alguma coisa e, portanto, nunca está coincidindo consigo. Vem daí a crítica de Hegel à linguagem hieroglífica acabada de Leibniz:

não se pode pensar em uma língua hieroglífica abrangente, de todo acabada: os objetos sensíveis são, na certa, capazes de signos que permanecem fixos, mas para os signos do espiritual o progresso da cultura intelectual, o desenvolvimento lógico progressivo leva a maneiras-de-ver mudadas a respeito de suas relações internas, e, por isso sobre sua natureza, de modo que assim apareceria também uma outra determinação hieroglífica. ${ }^{232}$

O que Hegel está apontando aqui é a plasticidade inerente à linguagem, o fato de que novas palavras necessariamente precisarão entrar em circulação para darem conta de novos desenvolvimentos de pensamento, ou seja, o fato de que as palavras são móbiles cuja função e uso são inscritas no tempo e no campo de objetos significáveis que se têm disponível. Nesse sentido, a língua também está inscrita no tempo e no desenvolvimento e, dada sua natureza de simplesmente ser sempre outra coisa que não si mesma, a ideia de um acabamento da linguagem é impossível porque é tomar a língua como não ligada à realidade da qual ela, no entanto, é dependente. Nesse sentido, se a realidade linguística do Espírito precisa se modificar constantemente porque precisa dar conta da realidade vivida, resta de todo impossível pensar num sistema fechado, não aberto para o mundo que se modifica, um sistema no qual $o$ fim da história já se deu de fato e o tempo não corre mais. Pois se, de fato, a história já tivesse acabado,

\footnotetext{
${ }^{230}$ HEGEL, 2017, p. 248.

231 Ibid, idem.

${ }^{232}$ HEGEL, 2017, p. 250.
} 
tudo o que há pra ser visto e nomeado já o foi ou pode sê-lo, sendo o processo de conceituação apenas uma questão de adequação de linguagem à coisa. Em suma, Hegel teria bastante razão para definir uma conceitografia nos exatos moldes daquela que ele critica, pois mesmo aquele conceito que considera central ao seu sistema (desenvolvimento) já teria dado os respiros finais e teria culminado numa totalidade que já permite adequação entre palavra e coisa. A resposta à modernidade seria uma resposta do entendimento com suas abstrações e cristalizações da realidade - justo a figura que aparece criticada como sendo central à linguagem proposta por Leibniz ${ }^{233}$. Mas não é isso que Hegel propõe.

A reflexão de Hegel sobre a linguagem e sua relação com a modernidade tem um caráter peculiar. Ela tanto investiga uma possível compreensão da linguagem tal e qual ela sempre foi, embora nunca tenha sido assim compreendida dentro de uma teoria, como também assume que existe no próprio elemento e possibilidade reflexivos um grau de aprofundamento somente possível no tempo de sua ocorrência. Daí que Hegel possa utilizar-se de contraposições explicativas, em sentenças como a que ocorre na comparação que faz entre hieroglifo e modernidade, em frases como: "a escritura alfabética é, em si e para si, mais inteligente: nela, a palavra - o modo peculiar à inteligência, mais digno de exteriorizar suas representações - é trazida à consciência, constituída objeto da reflexão." 234

Como bem sabemos, o alemão - mas também todas as línguas da Europa - se escrevem em escritura alfabética. Já a escritura hieroglífica (simbólica) se molda bem ao povo chinês, no entender de Hegel, porque seu povo possui uma "cultural espiritual

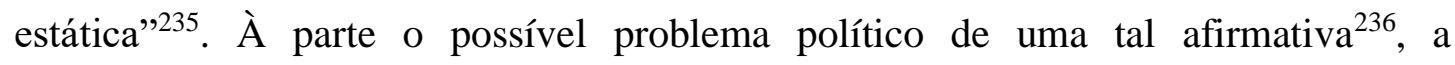

${ }^{233}$ HEGEL, 2017, pp. 249-250.

${ }^{234}$ HEGEL, 2017, p.251, itálico do autor, negrito nosso.

${ }^{235}$ HEGEL, 2017, p.250.

236 Seguimos aqui o expediente de COSSETIN, 2012, ao analisar o mesmo trecho. Adicionamos, apenas, que os critérios que adotamos a partir do século XX, como equidade entre humanos de culturas distintas ou o que se poderia chamar de multiculturalismo, bem como as considerações acerca de problemas relativos à identidade racial ou de gênero são de todo anacrônicos ao tempo hegeliano. Se esse critério for de fato adotado para julgar as afirmativas dos autores, i.e., se reduzirmos suas filosofias aos preconceitos de época, elas se esvaem como areia, uma após outra. Ademais, com isso temos aí um certo ganho narcísico, sem quaisquer ganhos para o pensamento além de um alerta. Não é possível, no entanto, fingir que tal questão não existe, de modo que assinalar o problema nos parece a melhor solução. Ademais, parece-me mesmo que Hegel se insurge contra uma dominação de muitos por poucos, a julgar pela citação que fazemos logo adiante. 
contraposição que Hegel faz aqui se torna inteligível num plano lógico: para um povo de cultura estática, cuja configuração se faz de modo tal que "uma pequena parcela da população mantenha a posse exclusiva da cultura espiritual”"237, ou seja, para um povo para o qual a dominação e a ausência de liberdade são as marcas principais, temos a estaticidade como resultado e o hieroglifo (símbolo) como modo maior de sua configuração de pensamento. Ao povo que tem todos como igualmente livres é necessária uma configuração linguística igualmente fugidia e negativa, que seja o duplo perfeito da liberdade que por meio dela se pode fazer ver. Essa, uma forma outra de dizer o que Hegel constantemente reafirma, i.e., que a linguagem é pensamento e que, por isso, a gramática dá as leis à língua e ao pensamento de uma tacada só.

Dito isso, fica mais claro, amplo e se torna inscrito na linguagem o pressuposto do desenvolvimento e o negativo que com ele vai. Não é apenas termos que se possam compreender de maneira conceitual clássica, e.g. como uma espécie de ordenador fixo da experiência racional e que não possuem inscrição no momento histórico no qual se dão. Antes disso, eles estão inscritos na maneira mesma pela qual nós articulamos o mundo e, por isso, no período histórico a partir do qual falamos, isso se torna ainda mais real, vez que a modernidade é o tempo do desenraizamento e é exatamente essa a função da linguagem. Por seu turno, a escritura alfabética, por ser composta de nomes, i.e. "sinal simples para a representação propriamente dita - quer dizer, simples, não dissolvida em suas determinações, e composta a partir delas" ${ }^{\text {238 }}$ corresponde melhor à maneira do funcionamento conceitual que deve ser próprio à modernidade precisamente porque ela faz ver de que modo as determinações estão presentes em um nome, i.e. o quanto de desenraizamento da coisa e inscrição desta no pensamento foram necessários para um nome existir. Em suma, faz com que seja possível a construção de uma série de frases compostas de palavras com significados diferentes e que, no entanto, só adquirem sua significação dentro de uma totalidade que será, ao mesmo tempo, composta por coisas diferente dela, mas delas dependente.

O funcionamento de uma frase, nesse sentido, é o espelho linguístico da afirmativa hegeliana sobre o a relação entre o verdadeiro e o todo i.e. "O verdadeiro é

\footnotetext{
${ }^{237}$ HEGEL, 2017, p. 250 .

${ }^{238}$ HEGEL, 2017, p.251, itálico do autor, negrito nosso.
} 
o todo. Mas o todo é somente a essência que se implementa através de seu desenvolvimento" ${ }^{239}$. Também numa sentença é preciso haver o desenvolvimento de alguma coisa que geralmente chamamos de sentido e que depende de um deslizar seriado de palavras que compõe o sentido, mas não o são. Uma frase é, portanto, uma união da identidade e da não identidade que, grosso modo, mantém essa sua identidade oculta para si, posto que todo falante tende a pensar que apenas tenta transmitir o sentido, as palavras sendo veículos intercambiáveis para tal ${ }^{240}$.

Com tudo o que dissemos aqui, conseguimos vislumbrar mais um problema na crítica de Feuerbach acima citada, como se elevássemos em um grau a mais na possibilidade crítica de observar seu texto crítico. Feuerbach assume que o nome Johann é capaz de se relacionar de maneira ontológica e essencial com aquele corpo/pessoa a que chama de irmão. Para efeitos de ênfase, desde o ponto de vista de Feuerbach seu irmão é Johann, ou seja, ele é seu nome singular tanto quanto todos os outros Johanns também o são singularmente. Existiria para ele uma intrínseca correlação entre o nome e o designado, de modo que o singular pode ser descrito $e$ referido pelo nome lhe é atribuído. Nada mais alheio ao funcionamento dos nomes próprios, tendo em vista que mesmo a nomenclatura "nomes próprios" funciona mais como ironia do que como verdade. Quando do nascimento de uma criança, todo pai e toda mãe se tornam Adão, nomeando aquela pequena cria por eles concebida, por vezes conferindo-lhe algum destino a partir desse nome. Sendo assim, o nome só é próprio na medida em que a pessoa o assume como tal porque não tem escolha e não porque existe uma relação intrínseca entre si mesmo e seu nome. O nome é, para o sujeito, uma negatividade na qual ele é forçado a se reconhecer com o passar do tempo, e as intempéries psíquicas que isso pode causar são um testemunho da dificuldade do nomear.

Por isso, pressupor uma ligação direta entre nomes próprios e pronomes é equivocado, mas revela também um desconhecimento de Feuerbach do que Hegel pensava também em relação aos nomes próprios. Não tanto que caso se dissesse algo sobre os nomes próprios Hegel fosse obrigado a recuar, mas que caso fosse confrontado

${ }^{239}$ HEGEL, 1992, p.31.

${ }^{240}$ Será essa a mesmíssima estrutura que permitirá Hegel passar de uma proposição raciocinante a uma especulativa. Veremos como no capítulo três, mas já tenhamos isso em mente. 
com eles Hegel responderia como Julieta disse outrora em parte de seu discurso na cena da bancada (balcony scene): "O que há num nome? Aquilo a que chamamos rosa, se de outra coisa se a chamasse, o mesmo doce perfume teria!"241. Em suma: não há relação essencial própria às palavras e é para isso que Hegel está apontando já na Fenomenologia, embora, por questões relativas ao problema específico que trata, o tenha feito a partir de "aqui" e "agora". Uma tal possibilidade de relação entre palavra e mundo vai ser gradativamente construída por Hegel ao longo da Fenomenologia e, posteriormente, na Lógica. Nunca será aquela que pensa que um nome é adequado a um sujeito, espécie de Johandenheit singular como queria Feuerbach, mas terá uma estrutura mais próxima àquela das frases ou, melhor ainda, de uma longa narrativa chamada história. O mundo historiado da Fenomenologia é justo o mundo do saber, mundo prenhe de linguagem que se sabe arbitrária na origem e necessária no fim.

É por isso que tomar o partido da consciência sensível de maneira marcadamente fenomenológica e contra Hegel, e ainda supor nisso uma crítica é completamente vão: Hegel não está preocupado em desvendar como o funcionamento dos nomes e da linguagem se dá para a consciência que nada sabe ainda de si, mas em demonstrar como que essa consciência, porque parte exclusivamente de si como a autoridade verdadeira, é incapaz de compreender o funcionamento da linguagem que usa. Embutida aí também está uma crítica do Eu como sujeito capaz de dar conta de se situar e atuar no mundo, ou seja, existe aí a crítica do sujeito identitário, capaz de dar conta do próprio processo de situação no mundo e dos seus modos de expressão, crítica essa que vai marcar a imagem desse sujeito a ponto do homem ser definido como sua ação, ou seja, seu mostrar-se evanescente no mundo.

Ademais, lembremos que a citação na qual Hegel fala dos signos como negatividade tem ainda um segundo componente, que é aquele referente à verdadeira negatividade, visto que a primeira, a abstrata, serve simplesmente para a destruição daquilo a que se refere (o que não impede, como vimos, dela possuir um uso instrumental e pedagógico). Tal negatividade verdadeira se refere à inteligência, que logo após é definida como aquela que modifica o signo linguístico de algo exterior em

241 What's in a name? That which we call a rose by any other name would smell as sweet! SHAKESPEARE, 2003, p.107. 
algo interior. Note-se: essa transformação faz da negatividade verdadeira porque transforma a temporalidade fugidia da palavra em temporalidade conservada ${ }^{242}$, movimento exatamente igual àquele feito pela consciência ao capitular de falar da exterioridade e começar a falar a partir do $\mathrm{Eu}$ ("Eu digo que é este agora, este aqui" etc.). Os movimentos que a consciência é forçada a fazer na Fenomenologia se repetem de maneira quase idêntica (embora dentro de uma dedução do espírito e não de modo experiencial) aqui nesse pedaço da Enciclopédia. É como se na Fenomenologia a consciência estivesse obedecendo à exata mesma lógica de construção que o signo possui, a saber, a lógica dialética. Isso não devia ser uma grande surpresa, posto que ambas as obras de fato são explicitamente animadas pela dialética; mas se torna surpreendente quando pensamos que a Fenomenologia chegou a resultados parecidos aos da Enciclopédia enquanto tratava de atitudes da consciência frente à experiência de conhecimento, enquanto essa seção da Enciclopédia simplesmente se preocupa em prosseguir a um acompanhamento dos processos do Espírito muito depois de já ter exposto a lógica dialética no primeiro volume. Dito de outra maneira, a Enciclopédia já apresentou os termos do jogo e os tematizou de maneira explícita, ao passo que a Fenomenologia apenas parece querer fazer com que a consciência se conscientize se implique no movimento do qual ela já faz parte. A Enciclopédia sistematiza e, num certo sentido, acompanha o processo momentâneo de movimento e verdade do Espírito; a Fenomenologia busca ensinar a pensar e a como chegar à dialética e ao saber absoluto. Na primeira, a Lógica é pressuposta como já apreendida no volume por nós citado; na segunda, é a ela que se quer chegar. Daí a surpresa: de dois polos distintos se constrói a mesma estrutura.

É por conta disso que nos soa curioso que a consciência siga o mesmo resultado linguístico do Espírito, porque nos dá uma possibilidade de leitura diferente da tese de rememoração e reconhecimento a partir da qual usualmente se lê a primeira obra de Hegel: lida junto com o resto da obra, a Fenomenologia poderia não se tratar apenas de uma rememoração que "nos prepararia para a Lógica" no sentido de que o livro destino agora sim se tornaria legível, porque aprenderíamos no primeiro livro a "chave de leitura"; antes, teríamos diante de nós uma forma de rememorar que nos mostra que

${ }^{242}$ HEGEL, 2017, p.255 
nós já estávamos preparados o tempo todo, só faltando o passo de saber disso. A ênfase aqui se mudaria de uma leitura segundo a qual nós "finalmente chegaríamos ao Saber Absoluto" para uma segundo a qual nós já estamos nele e o erro é justo pressupor que existe um além ${ }^{243}$. Ao fim da obra a consciência se dá conta que seu itinerário foi um sobrevoo sobre sua formação e se dá conta, também, que é necessário um abandono da ideia de existência transcendente outra.

A ideia de que o fim é o começo e o começo é o fim ganha, assim, outra coloração: ao final de tudo, o que perdemos não foi uma série de pressupostos que foram substituídos por pressupostos "melhores", esses sim verdadeiros; o que ganhamos foi uma possibilidade completa de deixar de pensar que haveria, no fim, qualquer coisa. Não uma obra de uma nova metafísica, mas de uma crítica radical desta: isso é o que parece emergir quando cotejamos as duas seções das duas obras. ${ }^{244}$ Mesmo os pressupostos adotados agora, negativo que sejam, dizem respeito ao momento histórico a partir do qual falam. O paradoxo hegeliano, em parte, é justo esse: ser autoconsciente do negativo é já ter contida em si a própria negação que seria capaz de gerar uma novidade, sendo a ela aberta.

A partir disso, todo o procedimento hegeliano da Fenomenologia, ou seja, a maneira concreta como opera, pode ser descrito como uma relação entre, alienação, déficit de reconhecimento e rememoração ${ }^{245}$. Com efeito, será graças à possibilidade de retrabalhar os signos e sua formação que o homem gradualmente poderá ascender ao pensamento especulativo ${ }^{246}$ e não é por outra razão que a aposta hegeliana é, ao longo de sua obra, aquela de justo apostar na rememoração contra a alienação à qual o homem está necessariamente submetido. No entanto, o procedimento dialético visa justo tirar a linguagem de posição exclusiva de signo e fazer advir a possibilidade do conceito, sendo esse compreendido como a possibilidade de acompanhamento do desenvolvimento e constituição de um processo o que, como citamos anteriormente, Hegel é explícito em afirmar. Não à toa é tarefa do conceito absorver o negativo que é

${ }^{243}$ E estaríamos bastante próximos de ZIZEK, 2012. lendo assim.

244 Apesar de tomarem caminhos profundamente diferentes dos nossos, visto que fazem outras obras ou autores intervirem, é precisamente essa a tese de Zizek e, por outros caminhos bastantes mais complexos, a de Lebrun.

245 SAFATLE, 2005, p.36.

${ }^{246}$ HEGEL, 2000. 
colocado pela linguagem no momento de sua entrada em cena. Explicitaremos melhor como isso acontece daqui por diante. Esse será um passo importante para que possamos compreender a diferença entre comportamento raciocinante e especulativo. Para isso, trabalharemos a posição que o nome e a gramática ocupam, bem como a posição da memória, que será figura central da filosofia hegeliana. A partir dela podemos reconhecer como o Sistema, em sua conclusão última, de fato "recupera aquilo que perdeu à negatividade", para falar com Arantes ${ }^{247}$, mas não é exatamente essa faceta dele que nos ocupa aqui. O que nos interessa aqui é tentar estabelecer de que modo a linguagem, posto ser essa espécie de ponte entre o contingencial e o conceitual pode assim servir sem que para isso precise ser um paradoxo ou um enigma e a memória nos parece ser o melhor caminho para isso.

\subsubsection{Desvio II: Alienar, rememorar, conceituar}

A memória aparece, conforme dissemos, logo depois uma longa teorização sobre o signo e a linguagem. Mas é bem verdade que antes disso ela possuirá uma espécie de resquício de sua proveniência animal, sendo inicialmente atrelada às imagens e aos sons, dois componentes do sensível ${ }^{248}$. Assim, num primeiro momento, a memória lida primordialmente com a ligação entre imagem e som tal e qual elas foram experimentadas pela intuição, porque ao lidar com elas estará unindo dois polos sensíveis, buscando orientar-se já para o pensamento ${ }^{249}$. Não nos alongaremos muito nisso, dado que o trecho que buscamos explicar da Fenomenologia, que é nosso alvo maior, já conta com a linguagem como presente, mas serão esses movimentos constantes de depuração do sensível em espiritual que a levarão ao estágio da memória que trataremos aqui. ${ }^{250}$ Indicamos apenas que a esse movimento de depurar o sensível

\footnotetext{
${ }^{247}$ ARANTES, 1993.

${ }^{248}$ HEGEL, 2017, p. 254.

${ }^{249}$ Ibid, idem.

250 Para um tratamento detido disso, cf. In: LINDORFFER (Hrsg), Hegel: Zur Sprache e também o capítulo de COSSETIN, 2012, dedicado a uma explicação gradual do processo.
} 
em algo gradualmente mais espiritual Hegel chamou de metáfora e atribuiu a todas as línguas a posse de tais elevações do espírito. ${ }^{251}$

No momento em que faz a ligação entre intuição e memória e encerrando em parte o momento em que versa exclusivamente sobre a linguagem, Hegel critica o tratamento dado a esta última em obras de seu tempo por seus contemporâneos: "Habitualmente, o signo e a linguagem são introduzidos em qualquer parte, como apêndice da Psicologia ou também na Lógica, sem se ter pensado em sua necessidade e conexão com a atividade da inteligência" ${ }^{252}$. O problema da ausência de ligação, para além da metodologia hegeliana que visa acompanhar o desdobramento do Espírito - é que, mesmo a partir de outras metodologias que não a sua, ou seja, mesmo assumindo que os outros autores estejam com a razão, não se pode perceber a ligação intrínseca entre a utilização do signo, o pensamento e a existência que daí resulta (lembremos a ligação entre símbolo, dominação e estaticidade cultural no caso chinês). Por conta disso, a necessidade de utilização desses pela inteligência não fica explicitada, restando obscura toda e qualquer tentativa de explicação de seu uso, o mesmo valendo para as consequências de determinadas formas de lida ou constituição da linguagem. Lendo a crítica de Hegel, podemos dizer que tudo se passa, no fim das contas, como se fosse evidente o porquê de usarmos signo e linguagem e, também, como se fosse possível estabelecer uma relação direta entre o signo utilizado e o elemento designado, algo que vimos não fazer sentido para o autor dada a arbitrariedade inerente à utilização de tais expedientes pela inteligência. $\mathrm{O}$ fato de os estudos referidos serem um apêndice mostra sua pouca importância e mostra, também, a distância que já separa Hegel desses que critica.

Além disso, ao criticar esses manuais, Hegel nos lembra que estamos diante da recuperação de uma característica fundamental do Espírito, a saber, seu processo. Não nos parece ser ocasional que um autor que dedicou tanto de seu ensino a ensinar a imbricação entre a história de algo e a existência dessa mesma coisa - estética, filosofia, história mundial, etc. só são lições na medida em que também são narrativas históricas e historiográficas - faça questão de pontuar que os materiais mesmos a partir dos quais

\footnotetext{
${ }^{251}$ HEGEL, ano. p. (estética)

${ }^{252}$ HEGEL, 2017, p.249.
} 
se faz história - contingências eventuais e palavras que expressam o universal - são vistos como ligados imediatamente, sem a devida preocupação com o estabelecimento do porquê do elo. Tanto assim que parte de sua elaboração posterior, até o parágrafo que culmina na definição de memória, tem por objeto a maneira como a palavra gradualmente passa de algo que apresenta o barulho que o humano capta dos animais e das coisas - do sensível, portanto - até gradualmente se transformar em algo que não possui qualquer necessidade de ligação com o sensível percebido, sendo então apenas o material para a construção do "ponto de vista do entendimento" 253 . Vemos, assim, que a função da linguagem, especialmente a da gramática é, em grande parte, a da construção ${ }^{254}$ da qual advirá o entendimento, reino tanto das representações estanques, quanto da poderosa capacidade humana capaz de nomear.

Que seja possível se espantar diante dessa possibilidade do homem já nos mostra o quão grande é a ênfase que Hegel dá para o fato de que o homem fala e habita a/na linguagem. Os motivos históricos para isso nos parecem de fácil demonstração: não obstante Herder fazer escola na época de Hegel quando da publicação de seus estudos sobre a origem da linguagem ${ }^{255}$ - tendo seu ensaio sido premiado -, Hegel ainda se debruçou longamente sobre os estudos de Humboldt sobre o assunto, especialmente sobre aqueles que versavam sobre as línguas de outros países. É de particular importância para Hegel o estudo do funcionamento da gramática de uma língua e de sua relação como espírito pois, antecipação que é, ela dará os limites do Espírito daquele povo.

A importância de uma língua não ser morta para um autor que tanta ênfase deu na morte como possibilidade de construção filosófica nos parece clara: a vivacidade de uma língua diz muito do caminhar do Espírito. Se a língua ainda é viva, ela ainda se anima com o élan daqueles que nela injetam algo. Mais do que isso, ela ainda designa uma realidade contemporânea e, portanto, ela é capaz de refletir sobre o passado, porque pode estabelecer a construção do presente a partir dele como esforço.

Diferente do que se poderíamos pensar num primeiro momento, o elogio de Hegel não vai em favor de uma gramática mais correta ou precisa. Dizemos isso porque

\footnotetext{
${ }^{253}$ HEGEL, 2017, p.248.

254 Idem.

255 TAYLOR, 1999, p.19.
} 
um reflexo inicial, a despeito de nossa reflexão até aqui, pode ser o de conferir à correção das palavras uma grande valia. Afinal, não obstante a argumentação até aqui - que fornece, digamos, o campo teórico a partir do qual isso pode ser pensado estamos falando de um autor que foi descrito por Hotho como alguém que passava as suas aulas atrás da palavra precisa:

Ele vacilava mesmo ainda no começo, tentava seguir, recomeçava, para de novo, falava e refletia; a palavra correta parecia para sempre faltante, mas de repente ela soava de modo inconteste... Agora se entendia o sentido preciso e claro de uma sentença e se esperava progredir. Em vão. Em vez de seguir adiante, o pensamento continuava rondando sem cessar o mesmo ponto, utilizando palavras semelhantes. Mas se, cansada e desfalecida, a atenção distraía-se e apenas após alguns minutos retornava à conferência subitamente sobressaltadas, ela se encontrava, então, como que por punição, apartada de todo o contexto, ${ }^{256}$

Ora, a palavra precisa não parece ser dependente de uma gramática excessivamente restritiva - o que o elogio do alemão, com sua gramática bastante maleável, sua polissemia, e sua capacidade de criação de termos por aglutinação já nos deixaria entrever. Daí que Hegel possa rondar em torno do mesmo tema (seu apreço por círculos já deve estar claro): a cada volta que dava, era e não era o mesmo tema que circulava, posto que o pensamento estava ali dando suas circunvoluções para a apreensão do que buscava, sendo sua busca aquele de uma gramática que lhe fosse própria. Essa é outra forma de dizer que à sucessão de palavras correspondia o ato mesmo de fazer filosofia tal e qual Hegel o pressupunha: um movimento e um processo que estabeleciam a gramática do pensamento e, por conseguinte, também a constituição da realidade.

Um pensamento assim não pode estar constringido em regras gramaticais imutáveis e de pouca mobilidade posto essas regras serem a ele (ao pensamento) estranhas. Não se trata aqui de um personalismo vão, espécie de exceção para um pensamento capaz de criar filosofia, como se o filósofo ganhasse uma licença especial. Se trata de uma regra inscrita na própria língua e, por decorrência, na própria maneira de filosofar. Se cabe ao pensamento descobrir seus limites e suas regras, ele o faz apenas na medida em que herda da gramática um primeiro e incipiente caminho a ser

${ }^{256}$ ADORNO, 2007, pp.227-228. 
depurado e complexificado pela filosofia. Vai daí que a gramática vai ser tão melhor quanto menos rígida for, vez que permite uma flexibilidade própria ao pensar:

O estudo das línguas que permaneceram de origem, que só nos tempos modernos se começou a conhecer profundamente, mostrou a respeito que elas contêm uma gramática muito elaborada no que é singular, e exprimem diferenças que faltam ou foram apagadas nas línguas de povos mais cultivados. A língua dos povos mais cultivados parece ter a gramatica mais imperfeita. ${ }^{257}$

Tanto a singularidade excessiva quanto a gramática desmesuradamente rígida se apresentam como problemas. No primeiro caso, podemos compreender bem o porquê: se cabe à língua, no entender de Hegel, construir signos linguísticos que sejam universais e se a relação entre eles é compreendida como antecipadora da forma do entendimento, decorre daí que os termos que se mantém calcados no sensível, bem como as línguas que os abrigam e saúdam, sejam vistos como impeditivos do pensamento. Eles seriam incapazes de esclarecer a distância existente entre palavra e coisa, fazendo com que a palavra possa ser tomada como correspondente da coisa posto aparentar ter com ela alguma relação essencial ${ }^{258}$.

$\mathrm{O}$ estranhamento necessário entre a palavra e a coisa ficaria estanque justo porque se teria a dificuldade de construir a noção de representação, conforme a crítica da certeza sensível já demonstrou. Afinal, no que se prendia ela se não na reificação da ligação entre seu saber e o objeto designado? Nesse sentido, já damos um primeiro golpe na crítica de que Hegel é um simples ator que mascara sua sanha teleológica com falsas inversões: a consciência sensível, se é capaz de ser educada, o é apenas porque num primeiro momento realmente acredita que diz a coisa quando a chama de isto. Ela ainda não ascendeu ao reino cartesiano das representações porque ainda não sentiu seu mundo se dilacerar e não teve que se abrigar em si como um ponto arquimediano.

${ }^{257}$ HEGEL, 2017 , p.249

${ }^{258}$ Esse tema será reexplorado quando diferirmos proposições especulativas e raciocinantes. Para uma antecipação, cf. 3.3 desta tese. Por ora, lembremos que ainda hoje alguns dos caracteres chineses têm certa semelhança com o que designam, ou seja, são visualmente simbólicos. 
Ela vive como se estivesse intuindo as coisas em sua riqueza, da mesma forma que aquelas línguas que atribuem um nome singular a uma coisa específica. ${ }^{259}$

Poderíamos, é claro, imaginar a figura de Hegel como o filósofo que tem uma posição colonialista e que crê em uma possibilidade de colocar as línguas em uma certa hierarquia de acordo com as capacidades de expressão que ele julga melhor ou pior. Se tal adjetivação é possível, é igualmente desviar da questão que está para ele em jogo aqui: o problema não é que existam povos mais cultos ou menos ou que certas línguas expressem mais ou menos coisas, que sejam mais ou menos atinentes ao singular do que outras. O problema, para ele, é que a singularidade das coisas seja vista como passível de ser expressa de maneira transparente, sendo esta não passível de expressão sem que se passe por um sem número de determinidades e por uma quota de opacidade inominável.

Como exemplos, usemos os momentos que Hegel fala de palavras que se mantém enraizadas no sensível, a saber, aquelas que "imitam barulhos das coisas"260, i.e. as onomatopeias. Tendo em vista que elas buscam se aproximar dos sons ouvidos, são tão variáveis entre si quanto é a cultura, justo porque elas se mantêm no contingente e não mais do que reflexo da contingência, que é por princípio não conceituável - é justo aquilo que cai do conceito. ${ }^{261}$ Sendo assim, elas são palavras que não expressam mais do que a sensibilidade particular de cada ouvinte inscrito em sua cultura, sendo antes um reflexo do ouvinte e de sua cultura do que do pensamento conceitual enquanto relacionado à linguagem. Se miau, meow, mèu, yaong são tão diferentes entre si e grosso modo, impossíveis de serem traduzidas, "miado" ou "o som que o gato faz" não o é. Isso é o ato de nomeação quando ele está, como diz Hegel, aplicado de maneira arbitrária em relação ao seu referente. Nada no sensível nos diz para chamar o barulho

259 Nota pessoal: me é impossível não pensar na incorreção do pensamento que se expressa comumente em relação às traduções de expressões enraizadas na língua de origem, como, por exemplo, "só a língua portuguesa tem saudade" ou só os japoneses têm wabi-sabi", uma espécie de arte japonesa que aprecia as belezas, rachaduras e imperfeições em detrimento da perfeição e da durabilidade eterna das coisas em sua manutenção enquanto algo novo. Primeiro, porque isso assume que a correspondência entre palavra e coisa circunscreve a coisa e a expressa de maneira precisa; segundo, porque pressupõe que nomear e apreender conceitualmente é a mesma coisa; terceiro, porque anularia completamente a possibilidade de que o leitor tenha entendido minha explicação de wabi-sabi e, portanto a compreensão de outras culturas em geral.

${ }^{260}$ HEGEL, 2017, p.250

${ }^{261}$ HEGEL, 2017, p.251. 
do gato de miado e é justo isso que nos permite comunicar a outra pessoa, falante de outra língua o nome arbitrário que escolhemos e a correspondência desse nome com o arbitrário de sua cultura.

Se a singularidade possui problema do enraizamento no contingente, problema similar existirá em uma gramática muito arrefecida. No caso de uma tal normatização do pensamento, será caso de simplesmente não haver espaço para a mobilidade do pensamento posto que a correção implicará sempre numa mesma perspectiva de suposição de adequação entre designante e designado. O tema, aqui, é o mesmo: tudo se passa como se a correspondência entre sentença correta e objeto sobre o qual se fala fosse capaz de expressar tal objeto, agora a partir de uma lógica adequada de justaposição. Tudo se passa, por assim dizer, como se um conjunto de sentenças pudesse ser um livro do mundo. Hegel não pode aceitar essa noção, afinal de contas, para que exista dialética, é preciso que a singularidade seja negada pela universalidade do signo linguístico e também é necessário que o pensamento seja capaz de rearticular a noção de conceito não como uma definição precisa, que se faz corresponder com seu objeto, mas como algo que é passível de ser apreendido apenas a partir da apreensão de seu próprio desenvolvimento ${ }^{262}$.

Damos, aqui, outro deslocamento da crítica às "pantomimas hegelianas": para se supor que a dita teleologia hegeliana é apenas uma série de falsidades e pseudodistorções numa reta que já tem seu ponto de partida e de chegada bem fixos, é preciso que se pense que todo o caminho é tão supérfluo quanto o era na dialética de Platão que buscava falar até instaurar o silêncio. No caso de Hegel, as coisas são bastante distintas e aparentar dialética hegeliana e a dialética platônica dos diálogos não nos parece adequado. Tal ligação entre dialética e diálogo - algo que se aproveita da origem etimológica dos termos, bem como do fato de Hegel usar um termo clássico já presente em Platão - se esquece das próprias críticas de Hegel à dialética de Platão, dizendo ela não ser a verdadeira dialética ainda. ${ }^{263}$ Curiosamente, um crítico de Hegel, Kierkegaard, foi quem melhor se atentou a isso comentando os dois autores: " $\mathrm{O}$ movimento dialético em Platão, justamente porque ele não é a dialética da própria ideia,

\footnotetext{
262 HEGEL, 1992, p.30.

${ }^{263}$ HEGEL, 2010.
} 
por mais engenhoso que seja o passo com que ele se move, permanece, apesar de tudo, estranho à ideia mesma."264 e ainda "Sócrates chegou à ideia da dialética, mas não possuía de jeito nenhum a dialética da ideia."265. Sendo assim, esse movimento que geralmente tenta transformar as duas dialéticas em parentes próximas ${ }^{266}$, é justo o que permite pensar que no Saber Absoluto tudo é silêncio quando, na verdade, é apenas o som ensurdecedor de todas as falas precedentes.

A partir daí somos reenviados de volta ao nosso texto da Enciclopédia, principalmente àquela definição que Hegel vai dar a algo bastante peculiar: o nome. A definição não será outra do que "a Coisa tal como ela está presente e tem validade no reino da representação"267. O que quer isso dizer? Primeiro, quer isso dizer que nomear é um ato que de antemão separa a coisa do termo que a nomeia, sendo assim uma apropriação da coisa pelo entendimento; segundo, na circunscrição precisa do nome à representação já fica claro seu lugar na ordem das coisas. O nome é já a coisa depurada de todo sensível na qual esta se via imersa e elevada à possibilidade de intercambialidade inerente ao entendimento. Quer isso dizer que quando nomeio algo, arbitrariamente já demonstro aí que meu entendimento é capaz de depurá-lo rompê-lo em partes e, também, torna-lo o negativo do que é - o que será nosso tema na próxima seção, mas já é bom termos em mente. Será justo a inscrição e reinscrição constante do nome que nos permitirá falar, finalmente, em memória.

Esse movimento inicial, no qual o Espírito constantemente nomeia uma coisa é uma etapa dele para tentar sair do estado de alienação no qual se encontra. Nesse sentido, o Espírito nomeando tenta se apropriar da coisa de forma imperfeita e o primeiro passo apenas separa, cinde, introduz uma negatividade que é a sua própria. Mesmo que já seja um passo além da Razão, ou seja, que já compreenda a realidade exterior e a si mesmo como momentos de uma universalidade, ainda não penetra nessa realidade e/ou ainda não sabe bem de que maneira pode compreender a opacidade das coisas. Razão pela qual ainda precisará compreender o objeto nomeado como diferente

${ }^{264}$ KIERKEGAARD, 1991, p. 175.

265 KIERKEGAARD, 1991, p.178.

266 Hyppolite algumas poucas vezes aproxima as duas ideias, Gadamer, por seu turno, as distancia de maneira bem enfática.

${ }^{267}$ HEGEL, 2017. p254. 
do nome dado, como se houvesse aqui uma essência particular ao objeto, razão pela qual a crítica a Mesmer aparece justo no momento em que uma reflexão sobre a palavra com um "exterior interior"268 aparece.

Mesmer foi um pesquisador que julgou existir um certo fluido corporal no humano que poderia ser manipulado a partir do uso do magnetismo e tais fluidos estariam ligados com quadros de patologias psíquicas ${ }^{269}$. Hegel faz uma apreciação da doutrina no adendo do parágrafo 406, indicando como o que ocorre ali não é diferente do que se diz ter ocorrido em histórias míticas ${ }^{270}$. O que nos interessa dessa referência é o fato de ela ser alguém que tinha uma prática de cura que se abstinha da palavra para pensar e que pressupunha dominar algum fator extra linguístico a partir de imãs. Quando foi dado por farsante, teve de se isolar na Áustria, posto que o tal fluído do qual falava não deu qualquer sinal de existir. Mais tarde, a explicação que a psicanálise encontrará para isso será uma dimensão da transferência, dimensão essa muito similar àquela de sua prática mãe, a hipnose. Nesse sentido, o paciente é como que hipnotizado e se cura por mera imposição e quebra das resistências por parte da autoridade conferida à pessoa que realiza o tratamento. É uma sugestão não a manipulação de um fluido corporal que faz o trabalho ou, em termos hegelianos, é o pensamento eivado e imerso na linguagem e por ela transmitido por meio das sugestões que cura a própria consciência. Disso podemos tirar uma lição geral da filosofia hegeliana: lá mesmo onde se supõe um terreno no qual há pensamento sem linguagem (intuição intelectual, apreensível imediata de cunho gnóstico, fluidos, etc.) existe uma linguagem operando sem que ela esteja sendo pensada pelo operador.

Retornando à questão da memória, será do constante embate com a realidade externa que surgirá a necessidade de se pensar o que faz com que a ligação inicialmente arbitrária entre os signos linguísticos (doravante nomes) e a coisa se mantenham os mesmos. Será caso, então, da consciência conseguir perceber que ela quem é "o laço vazio, que fixa em si mesmo e mantém em ordem fixa a série dos nomes". ${ }^{271}$ Desse processo constante de aperceber-se (poderíamos dizer, desse trabalho paciente do

\footnotetext{
${ }^{268}$ COUTINHO JORGE, 2017, p.26.

${ }^{269}$ HEGEL, 2017, p.142.

${ }^{270}$ Ibid, idem.

${ }^{271}$ HEGEL, 2017, p. 256.
} 
pensamento) o Espírito se tornará cada vez mais apta a notar que a relação que ela supõe fazer entre sua representação, seu eu, e a Coisa está bastante errada. Quer isso dizer, então, que ele abandona completamente tudo o que faz e que finalmente encontra a representação correta? Não. Ele apenas nota que o movimento que ele faz é duplo, i.e., que ele é, "enquanto memória mecânica, em um só, aquela mesma objetividade exterior e a significação" 272 , como que fazendo um trabalho duplo de separar e juntar o que ela mesma separou. É como se o Espírito precisasse demais do sensível de corresponder a ele para que as coisas fizessem sentido para ele. Como se ele ainda buscasse apreender a realidade exterior e acreditasse que ela é permeável à linguagem.

Vejo a maçã que está em minha frente. Penso na ligação entre a maçã e o fato de chama-la de maçã. Nesse processo de reflexão, penso que a única coisa que me faz chamar tal fruta de maçã é porque ela possui certas características i.e. formato, cor, cheiro, gosto e afins similares àquilo que o tempo todo em minha vida chamei de maçã, ou seja, dou-me conta de que sou eu quem alinho os nomes, como dissemos acima e que sou eu quem nomeio o objeto exterior daquela forma. Em suma, eu atribuo a mim a representação e compreendo que quem faz a ligação entre representante e representado sou eu mesmo, como se o procedimento não se adequasse perfeitamente à coisa porque é algo que eu faço. Num momento posterior, dou-me conta de todo esse processo e abandono-o como fútil, ficando apenas com minhas representações da coisa que, justo por isso, deixam de ser apenas minhas representações e passam a me permitir que eu conheça "no nome, a Coisa"273. Abandono aquilo que na linguagem hodierna se chamaria de "realidade objetiva", em prol do nome da Coisa sem, no entanto, positivar algo que é externo e inacessível, como o que "a coisa verdadeiramente é” - e.g. a coisa em si em Kant. O mesmíssimo movimento intencionado pela Fenomenologia reaparece aqui como um movimento linguístico a partir da relação entre nome e coisa ${ }^{274}$.

${ }^{272}$ HEGEL, 2017, p. 257.

${ }^{273}$ HEGEL, 2017, p.258.

${ }^{274}$ HEGEL, 1992, pp 70-71. Esp: “Com efeito, a consciência, por um lado, é consciência do objeto; por outro, consciência de si mesma: é consciência do que é verdadeiro para ela, e consciência de seu saber da verdade. Enquanto ambos são para a consciência, ela mesma é sua comparação: é para ela mesma que seu saber do objeto corresponde ou não a esse objeto. $\mathrm{O}$ objeto parece, de fato, para a consciência, ser somente tal como ela o conhece. Parece também que a consciência não pode chegar por detrás do objeto, [para ver] como ele é, não para ela, mas como é em si; e que, portanto, também não 
Note que não há abandono da realidade pura e simples aqui, mas sua depuração ao campo do pensamento, posto que é justo a partir do contato entre a realidade objetiva e a arbitrariedade do signo que sou obrigado a abandonar minhas tentativas de apreensão desta tal e qual ela "seria em si mesma". Qualquer positivação de um "em si mesma", para Hegel, significa um desconsiderar o limite humano ou, pior uma espécie fútil de movimento que, ao mesmo tempo em que conhece, tenta retirar dos resultados do conhecimento aquilo que é próprio da faculdade do conhecer. ${ }^{275}$ É, num certo sentido, como se Hegel levasse às últimas consequências à intuição de Kant, segundo a qual não se pode conhecer além dos fenômenos: se não posso conhecer além deles, sequer posso saber que existe um algo essencial que resiste ao meu conhecimento. Dito de outro modo e repetindo o que constantemente tentamos manter em mente aqui, não é que o sujeito seja incapacitado para conhecer e precise de outra representação, mas que a coisa seja opaca e resistente à assimilação total, razão pela qual a figura maior de lida com elas e do seu conhecimento não é outra que o trabalho. ${ }^{276}$

\subsection{Rememoração, matemática, fim da história}

Para concluirmos esse capítulo, uma síntese do que foi pensado até aqui e uma demonstração da presença desses temas da Enciclopédia em nosso Prefácio se faz necessária. Pensamos ser o melhor caminho tomar o momento de crítica à matemática efetuada por Hegel para demonstrar o pressuposto que anima toda a sua noção de rememoração. Sua principal crítica, como é sabido, é à abstração que a referida ciência faz de todas as entidades sobre a qual versa. Nesse sentido, então, a matemática excluiria o caráter autopoiético da vida ou o tempo, equânimes em sua pena posto ser

pode examinar seu saber no objeto. Mas justamente porque a consciência sabe em geral sobre um objeto, já está dada a distinção entre [um momento de] algo que é, para a consciência, o Em-si, e um momento que é o saber ou o ser do objeto para a consciência. O exame se baseia sobre essa distinção que é uma distinção dada. Caso os dois momentos não se correspondam nessa comparação, parece que a consciência deva então mudar o seu saber para adequá-lo ao objeto. Porém, na mudança do saber, de fato se muda também para ele o objeto, pois o saber presente era essencialmente um saber do objeto; junto com o saber, o objeto se toma também um outro, pois pertencia essencialmente a esse saber. Com isso, vem-a-ser para a consciência: o que antes era o Em-si não é em si, - ou seja, só era em si para ela. Quando descobre, portanto, a consciência em seu objeto que o seu saber não lhe corresponde, tampouco o objeto se mantém firme. Quer dizer, a medida do exame se modifica quando o objeto, cujo padrão deveria ser, fica reprovado no exame."

275 HEGEL, 1992.

${ }^{276}$ HEGEL, 1992. 
esse justamente definido como "essa pura inquietude da vida e diferenciação absoluta" 277 . Somos reenviados com isso à seguinte questão: no que isso acarreta para um autor que tem por objetivo, ao menos nessa parte da seção, tratar de rememoração de um modo que ela se mantenha viva?

A primeira coisa que podemos depreender é que, ao rememorar, não é tanto que haja uma execução de uma mera equalização entre a representação presente e um passado existente, mas sim a articulação lógica dos momentos pregressos, a partir de um horizonte de presente, em uma série de sucessões que farão sentido ao ser presentificado. Metaforicamente, poderíamos dizer que não se trata de um dicionário conceitual, mas de uma gramática dos eventos. Consegue-se, na construção mesma dessa gramática, a maneira pela qual um momento, em seu desenrolar, deu origem, ao findar, a outra coisa. Ao mesmo tempo que há a construção, há também um descobrimento da maneira pela qual aquilo que encontramos no presente tornou-se aquilo que ora vislumbramos. O processo de construir, no entanto, não é pensado como apenas uma projeção de uma consciência que tem seu ponto de vista específico (como num perspectivismo), apesar dele influenciar de maneira direta na aparição do objeto (daí ser uma fenomenologia); antes disso, todo o esforço de Hegel é o de tentar fazer sua própria filosofia se tornar o espelho e a descrição exata da processualidade do real em seu acontecer mesmo ${ }^{278}$, posto que para além da aparição dos objetos e da novidade que tais aparições são, existe a construção sub reptícia de uma lógica. O ponto de vista do Para nós, figura que já sabe da totalidade, compreende a lógica do processo unicamente porque já se formou.

Expandindo um pouco sobre essa figura, o Para nós é o ponto de vista de quem não está imerso mais nas experiências do livro e quem, por vezes, antecipa o resultado a ser alcançado. Quer isso dizer que, por mais que na primeira leitura Hegel já assuma e coloque sua existência de maneira clara, ele apenas está ali presente porque a consciência precisa antecipar a totalidade abstrata para posteriormente preenche-la, por assim dizer, com as experiências pelas quais passa. Esse o sentido de Hegel dizer da Fenomenologia, ao seu fim, que ela lida com totalidade abstrata e experiência, ao passo

\footnotetext{
${ }^{277}$ HEGEL, 1992, p.46.
}

${ }^{278}$ ADORNO, 2007, p,205. 
que diz da Lógica - que à época apenas era um projeto - que ela lida com o desenvolvimento do todo momento a momento. ${ }^{279}$ Isso indica que na Fenomenologia, por seu objetivo de introdução e formação, Hegel já se utiliza da lógica, fazendo com que ela seja uma lógica que se logiciza para a consciência.

Essa última frase lança a exata luz a um problema inerente às construções de Hegel que, em grande parte, podem ser lidas como uma mera convenção do autor, como a seleção que faz dos eventos históricos e filosofias precedentes importantes para a composição do Espírito. Ora, mas se o critério mesmo a partir do qual vai ser observada a história é o presente a partir do qual a história vai ser construída, a observação acerca dos acontecimentos tem na própria atualidade do presente sua razão de ser. A possível correção da rememoração deve ser medida pelo tanto do presente que a construção lógico-dialética da formação permite compreender. Não que ela deva simplesmente corresponder, adequar-se ao objeto de que ela fala. Esse "nominalismo do conceito" 280 passa ao largo do que Hegel tem em mente. Antes, que aquilo que está sendo pensado possa ver, nesse pensamento, sua origem e lastros históricos, sociais e filosóficos. Se é evidente que será algo diferente de sua própria formação, é igualmente verdade que decorrerá da sucessão desses momentos. Isso porque, para o autor "na totalidade do movimento, compreendido como repouso, o que nele se diferencia e se dá um ser-aí particular é conservado como algo que se rememora, cujo ser-aí é o saber de si mesmo; como esse saber é também imediatamente ser-aí" 281.

Existe, portanto, uma conservação, posto que a Aufhebung é um processo negativo, mas que conserva, ou seja, ele é o processo mesmo de elevar, negar e também conservar. Tudo o que se conserva, não o faz, obviamente, de mesmo modo, mas guarda ainda um certo grau daquilo que foi outrora e o traz para a nova unidade. $\mathrm{Na}$ Razão, figura última do primeiro volume da Fenomenologia e momento chave para que a consciência se reconheça Espírito, tanto a consciência quanto a consciência-desi estão conservadas, a última não anulou a primeira. Mas elas, porque se sabem presentes em outra estrutura que não aquela de outrora, já são outra coisa, posto não serem a única forma da consciência se relacionar com a realidade. Elas ainda são elas

\footnotetext{
${ }^{279}$ HEGEL, 2000.

280 Ibid, p.204.

${ }^{281}$ HEGEL, 1992, p.46, itálicos do autor.
} 
mesmas, mas guardam consigo a negatividade de todo o processo de chegada ao momento Espírito sendo por isso, também, diferentes do que eram outrora. São diferentes a si mesmas ao passo que se mantém sendo identitárias.

A rememoração, ao incidir sobre esse aspecto do que se mantém na constância, não faz mais do que reconhecer uma linha que parece ser a exata mesma que se mantém desde o começo, que Hegel identifica vez com a autoconsciência, vez com a liberdade, ambas indissociáveis para ele ${ }^{282}$ posto que uma razão que não pode se externar no mundo por constrição termina estanque, como sua crítica da escrita simbólica nos fez ver bem.

Sob esse ponto de vista, nos parece compreensível que Hegel pense, então, num fim da história. A tese não é enunciada diretamente na Fenomenologia, mas dado o fato de já se falar que só se pode falar de algo ao seu fim, ela já é passível de ser antecipada, pois isso faz com que a própria Fenomenologia comece do seu fim tanto fático (Hegel escreveu o Prefácio ao término da obra, como dissemos), quanto lógico (o Prefácio sendo a conclusão e a junção de pressupostos da obra). Quando Hegel disso fala, não se trata, obviamente, da ausência de eventos que serão capazes de mudar os rumos da humanidade, posto que Hegel não vê a filosofia como capaz de versar sobre o mundo efetivo, em seu acontecer contingente. O que Hegel visa apontar é um esgotamento na possibilidade de caminhar adiante, posto estarmos caminhando pari passu com a negatividade enquanto horizonte de compreensão.

Pensemos "modernidade" (termo e tempo) por alguns momentos: um tempo que para se compreender utiliza para um termo de nomeação como "modernidade" já diz muito sobre a copresença entre o negativo e a existência hodierna. Pois moderno é sempre uma referência temporal que diz respeito ao agora, ao momento presente, que se esvai tão logo o capturamos. Nomear-se assim é, em grande parte, nomear-se como aquele tempo que só se permite compreender como uma passagem em direção a outra coisa. Ser moderno é se compreender em constante estado de atualização e negação,

${ }^{282}$ HEGEL, 2010. 
razão pela qual nada passa pela modernidade e fica para sempre, pois a modernidade é o puro passar. ${ }^{283}$

Dito isso, não é à toa que, para efetuar a mudança lexical quando precisamos nos referir ao tempo após a modernidade, se faz necessária uma construção composta ou uma sinonímia do termo em questão, i.e. falamos em contemporaneidade ou filosofia contemporânea, hipermodernidade, pós-modernidade ou filósofos pós modernos etc. Ademais, apesar de hoje termos uma tal mudança lexical proposta, o gesto básico de reflexão sobre as condições de possibilidade da existência histórica humana, ou seja, uma reflexão autoconsciente sobre a humanidade e seus destinos, não deixou de ser o exato mesmo horizonte a partir do qual os humanos que se dedicam a refletir operam. O gesto reflexivo sobre nós mesmos, i.e., a tentativa de chegar a uma autoconsciência se mantêm exatamente igual. Nesse sentido a história, de fato, parece ter acabado, posto que as novas tentativas ainda repetem a mesmíssima logica de funcionamento reflexivo que Hegel já estabeleceu.

Era a isso que Foucault aludia no trecho que citamos no começo de nosso capítulo, quando classificou a filosofia hegeliana de insidiosa: não é possível pensar “em nós mesmos" e em nossa condição sem ouvir o eco da voz hegeliana e de sua reflexão sobre o Espírito. Nesse sentido, uma reflexão materializada em linguagem ainda que sobre ela reflita, ainda que introduza o inconsciente, ainda que introduza uma série de forças - se mantém buscando a referencialidade correspondente, ou seja, se mantém tentando descobrir quais são as condições de possibilidade da humanidade tal e qual ela se apresentar no presente e, a partir disso, traçar uma história, em algum grau. Por mais que noções como o inconsciente busquem trazer uma equivocação, resta claro que ainda se trata do humano pensando seus equívocos. No fim das contas, o problema que Hegel traz é a ausência de um fora de si, posto mesmo o si já estar imbricado no que seria seu fora, a saber, o outro.

Assim, dado que a linguagem introduz uma negatividade e uma alteridade fundamentais ao pensamento, posto que só se pensa a partir do pensamento de outros e da linguagem que é alheia às coisas, toda filosofia precisa se constituir, queira ou não,

${ }^{283} \mathrm{O}$ que a fórmula de Marx, tornada título de livro por Marshall Berman, "tudo que é sólido desmancha no ar", traduz bem. Nesse sentido, modernidade e capitalismo têm ambos uma integração radical. 
como um negativo que capta sua própria negatividade e as condições de sua existência. O gesto reflexivo, por se ver consumado na linguagem e nos conceitos dialéticos, termina a história porque é a culminância da tentativa de apreensão de si, sua forma gramatical mais bem acabada ${ }^{284}$.

${ }^{284}$ LEBRUN, 1988, pp.40-59. 


\section{4 \\ Das proposições raciocinantes às proposições especulativas}

Chegamos, finalmente, ao momento no qual poderemos explicar a maneira pela qual a articulação da proposta hegeliana entre negativo e formação se faz de maneira a fornecer a passagem de uma atitude tal e qual a de sua época - que ele qualificou de raciocinante - e a atitude especulativa ou conceitual, que é a sua. Partiremos da maneira pela qual ele e diagnostica a filosofia e (m) seu tempo, pois este é um ponto de partida que nos mostra o porquê da aposta hegeliana ser numa crítica imanente ao que então circulava, ou seja, uma crítica que tenta radicalizar a proposta kantiana para além do quanto ela havia conseguido avançar ${ }^{285}$. O deslocamento de uma filosofia preocupada com definições e com a verdade destas para uma história das formas do Espírito é pressuposto ser o caminho da mudança filosófica almejada por Hegel. É mostrando para a consciência seu caráter de Espírito e para o Espírito sua formação que Hegel busca deslocar o centro de gravidade da filosofia do positivo e das definições adequadas, para o caminho do negativo e da consumação do desenvolvimento.

A reboque disso virá, ainda, a explicação do modo que a linguagem e a história adentram e se articulam para, no Prefácio, apontarem o caminho que será seguido. Uma vez que dependerá de dois tipos de proposições distintos, dependerá fundamentalmente de dois enquadres distintos de linguagem, embora as proposições se mantenham, se pensarmos em termos de seu conteúdo. Quer isso dizer que será caso, para Hegel, de deslocar o lugar a partir do qual uma proposição é enunciada e lida e isso só se consegue a partir da expansão da compreensão da linguagem. Não mais instrumento que fala no presente e expressa uma interioridade, a linguagem precisará ser compreendida não só como formadora do pensamento, mas também como uma ação num campo de expectativas de reconhecimento social. Vejamos como isso se dá.

${ }^{285}$ Nossa leitura, aqui, é muito informada por aquela de PIPPIN, 1989 e LONGUENESSE, 2007, embora a ultima esteja lendo a Lógica. 


\subsection{O problema do entendimento}

Talvez uma das noções mais difíceis de se compreender e aquela que, quando compreendida, mais auxilia na compreensão da obra de Hegel como um todo, é a sua noção de entendimento. Embora o termo faça, de fato, referência ao autor que é diagnosticado como aquele que inaugura o idealismo - Kant -, entendimento em Hegel diz muito mais do que simplesmente aquilo que organiza a compreensão e o conhecimento humanos como o faz no autor de Köningsberg. Hegel amplia essa noção para uma espécie de comportamento filosófico comum e que organiza a experiência filosófica desde o seu começo até o sistema de Schelling, seu antecessor (de Hegel) imediato. Incluídos estão aí os Iluministas, os românticos e os cínicos modernos, um grupo bastante heterogêneo, mas que partilha uma certa forma de se mostrar em relação ao conteúdo que tenta apreender e falha por motivos bastante entremeados ${ }^{286}$.

Para Hegel, em todos esses autores o mesmíssimo problema se mostra, ainda que de formas distintas: toda vez que buscam ensinar ou apresentar quaisquer noções filosóficas, tomam o assunto por acabado, vez que tendem a pensar que toda a filosofia que os antecede será substituída pela sua. Essa é a dimensão epistemológica partilhada, aos olhos de Hegel pelos três grupos. Já vimos isso ao começo da tese, quando analisamos a crítica de Hegel sobre a maneira pela qual os sistemas filosóficos são pensados como substituindo e não tanto prolongando uns aos outros, de modo que a refutação é o caminho da destruição do sistema anterior, não de sua continuidade ${ }^{287}$. Aqui essa crítica ganha nomes, cores e obras. Em uma expressão: toma corpo. Reexaminando o problema, aqui, podemos dar mais uma "volta no parafuso", por assim dizer e entender o que esse corpo tem de patológico para Hegel.

Para que os filósofos anteriores se coloquem como aqueles que foram capazes de tomar seu sistema como uma resposta definitiva, é preciso que cada autor, ao pensar

${ }^{286}$ Devo essa observação da junção do Romantismo Alemão com o Cinismo moderno a Safatle e sua indicação de bibliografia por ele produzida. Ela aparecerá citada ao longo deste capítulo.

${ }^{287}$ HEGEL, 1992, p. 22. 
filosoficamente, não se conceba como inscrito dentro de uma história da filosofia segundo a qual o antecessor é condição de possibilidade de sua formação. É preciso, portanto, que desde o ponto de vista de Hegel esses autores pensem ahistoricamente, de modo que seu pensamento não tenha outro tipo de relação direta com toda a história que o precedeu que não uma relação de negação abstrata. Uma tal negação não reconhece a sua própria pertinência de a um continuum histórico e, tampouco, a maneira pela qual essa história o permite pensar o que pensa. Em suma, um tal autor não se vê como parte integrante de uma tradição com a qual dialoga; no máximo se vê como o coroamento de um processo que sempre e a toda vez se iniciou e se pôs em marcha de maneira imperfeita.

Essa forma de conceber a relação entre a filosofia, a história e o mundo, se mostra na maneira pela qual os pensadores buscaram projetar na realidade empírica, terreno da contingência, um padrão lógico, somente encontrável no próprio pensamento. Assim sendo, a busca pelo padrão que seria capaz de subsumir o múltiplo ao uno é justo a busca filosófica por excelência até pelo menos Hegel ${ }^{288}$. Hegel chamou a isso de "noção" em detrimento de "conceito", posto esse último guardar em si a multiplicidade e o desdobramento do real em sua lógica.

O problema todo não é, simplesmente, que a reunião do múltiplo numa unidade abstrata seja uma destruição da multiplicidade do efetivo, mas também que o próprio pensamento conceba que o que há de essencial existe como que descolado de suas características - e a separação das coisas numa oração entre sujeito e predicado como unidades contrapostas já nos atesta o quanto isso é o caso. A essa separação do predicado e do sujeito, do acidente e da essência, do passageiro e do eterno, etc. Hegel dará o nome de abstrato ou abstração posto definir uma identidade como prescindindo das e não sendo composta por suas relações diferenciais ${ }^{289}$. Para Hegel, então, a relação de diferenças é que compõe a identidade e a maneira lógica pela qual isso se dá é esmiuçada na Lógica.

Hegel não está, com isso, dizendo que entre a realidade e o pensamento não exista uma relação de homologia e de estruturação comum; dissecar isso será também

\footnotetext{
288 Ao menos é essa a tese de LEBRUN (2000) a qual seguimos nesse aspecto.

${ }^{289}$ Isso se repete tantas e tantas vezes na Fenomenologia que qualquer parte do Prefácio
} 
o trabalho da Lógica. Antes, Hegel está apontando para o fato de que a abstração da realidade, que se pretende como pensando-a, não apresenta quaisquer referentes reais, mas apenas recortes da realidade que o pensamento faz valer como verdades absolutas que estão para além das próprias coisas. Em resumo, o pensamento que poderíamos chamar de metafísico e que se estende até Kant ${ }^{290}$ não havia se dado conta de que o que fazia não garantia, de maneira nenhuma, a realidade externa a qual julgava estar explorando. Segundo Hegel, mesmo o recuo kantiano em direção ao sujeito transcendental tem o mesmo problema:

\begin{abstract}
Aliás, o sujeito (Subjekt) é, de início, posto como o Si fixo e objetivo, donde o movimento necessário passa à variedade das determinações ou dos predicados. Aqui entra, no lugar daquele sujeito, o próprio Eu que-sabe (wissende) - vínculo dos predicados com o sujeito que é seu suporte. Mas enquanto o primeiro sujeito entra nas determinações mesmas e é sua alma, o segundo sujeito - isto é, o Eu que-sabe encontra ainda no predicado aquele primeiro sujeito, quando julgava já ter liquidado com ele, e queria retornar a si mesmo para além dele. Em vez de ser o agente no movimento do predicado - como o raciocinar sobre qual predicado deve ser atribuído ao sujeito -, deve, antes, haver-se com o Si do conteúdo; não deve ser para si, mas em união com ele. ${ }^{291}$
\end{abstract}

As referências a um primeiro sujeito e a um segundo sujeito, aqui, dizem respeito ao sujeito no duplo sentido próximo daquele do inglês ou do alemão, onde subject/Subjekt pode dizer tanto aquele que age, numa oração, quanto aquele que é o assunto em questão. Hegel joga com esse duplo sentido para mostrar que, no caso do recuo kantiano ao sujeito transcendental - ápice da atitude raciocinante em termos epistemológicos -, sempre resta uma atitude dupla: para pensar o objeto que tem em sua frente, Kant antes precisa retornar às categorias do sujeito, de modo que todo enunciado com pretensão de verdade precisa antes ser como que traduzido para uma percepção codificada pelo sujeito transcendental $e$ se restringir a isso, posto positivar uma realidade "mais real" para além. Dito de outro modo, em Kant o sujeito não sabe se fala da realidade em si, posto que do "em si" só se sabe a existência. Isso ocorre porque a separação, efetuada pelo juízo, já é, ela mesma, insuperável, dado ser primordial. Assim, o próprio ato de julgar (lembremos, do alemão Ur-Teil, separação

\footnotetext{
290 LEBRUN, 2002.

${ }^{291}$ HEGEL, 1992, p. 55.
} 
primordial $^{292}$ ), já leva à separação insuperável entre sujeito e objeto, vez que já coloca uns como juízes, outros como réus (e a metáfora do tribunal da razão se torna menos casual, especialmente se nos lembrarmos que a deduktion falada por Kant é a jurídica de seu tempo e não a dedução lógica).

Sendo assim, a pergunta kantiana sobre as condições de possibilidade do conhecimento, se tem por mérito levantar a questão acerca do procedimento de construção do que se chama realidade objetiva no processo de conhecimento, tem o demérito de se deter antes de realizar o procedimento de efetuar a crítica à cisão da realidade efetuada no processo de julgar que também é seu objeto na CRP. Ao delimitar a participação humana na construção do objeto do conhecimento em sua CRP, Kant está se colocando a questão acerca da participação das faculdades humanas na apreensão do objeto que visa conhecer e, apesar de decodificar seu funcionamento, não consegue apreender - menos ainda resolver - seus problemas, esse último pronome possessivo funcionando tanto para o autor, quanto para as faculdades humanas. Resta ainda por pensar a maneira pela qual o sujeito pode não ser alienado da realidade, posto que os constructos que faz, no melhor dos casos apenas tocam algo próximo à coisaem-si. Da "realidade real" o sujeito tem, no fim das contas, poucas certezas e sabe muito pouco, o horizonte da coisa-em-si servindo sempre de uma distância infinita.

Para Hegel, a esquematização da razão pura, longe de ser apenas uma resposta a uma questão circunscrita às possibilidades de conhecimento colocada por Kant - ou seja, de ser apenas epistemologia-, é também reveladora do procedimento inerente à toda atividade filosófica até então e, portanto, se espraiou na ética e na estética. É como se Hegel estivesse afirmando que, ao construir sua figura do entendimento, Kant foi aquele quem descobriu como a filosofia como um todo até então funcionava. Não à toa, será muito fácil para Hegel equiparar duas figuras tão distintas quanto o Nous de Anaxágoras e o entendimento kantiano. De ambos se pode dizer a mesma coisa, a saber que "em vez de penetrar no conteúdo imanente da coisa, lança uma vista geral sobre todo, e vem parar sobre um ser-aí singular do qual fala; quer dizer, não o enxerga de

${ }^{292}$ Hölderlin extrai muitas consequências dessa forma de nomear o juízo, ao passo que Hegel se foca na ética que decorre da separação que um julgamento ocasiona. Cf. MÜLLNER, 2011 e também QUEVEDO, 2018 e o texto do próprio Hölderlin, Urteil und Sein, citado na bibliografia. 
modo nenhum"293. Ambos os filósofos têm seu mérito, posto que não se trata de um desprezo pelos autores: o de Anaxágoras, o de situar o pensamento como fundamental, o de Kant o de descobrir a estrutura do pensamento guiado pelo entendimento; mas ambos têm também em comum o problema de colocar a abstração por eles feita como a verdade das coisas, sem nunca considerar a lógica imanente do real e, menos ainda, seu desdobrar fenomenológico e a proveniência do primeiro do segundo. Em última instância é, como já vimos, como se buscassem forçar à realidade empírica o mundo estanque do entendimento e, com isso, perdessem tanto um quanto o outro.

Todo o problema, para Hegel, é que o procedimento de abstração se julga um procedimento descobridor, ou seja, tanto Kant quanto Anaxágoras estariam promovendo uma abstração do real, mas chamando o que fazem de descoberta. Kant é quem acaba, a revelia de si mesmo para Hegel, pondo a nu esse procedimento ao (agora sim) revelar o caráter de abstração conceitual à revelia da realidade, próprio a toda filosofia. É como se os filósofos tornassem a realidade estanque em seu pensamento e entendessem que o estático, o parado, o não móvel do seu pensar é o correto, todo desvio sendo pensado como destruição definitiva daquele objeto que se tem à frente. A dialética, se é movimento, é movimento precisamente porque permite que entre A e não A exista diferença e identidade ao passo que, para Hegel, os problemas de Kant e Anaxágoras são os mesmos porque ainda existe a necessidade de corresponder exclusivamente a uma possibilidade sem que a negação dessa possibilidade seja levada em conta como um resultado tão satisfatório quanto a possibilidade inicialmente projetada.

Nota-se, aí, que o mérito de Kant é descobrir e teorizar sobre o entendimento, a palavra "descobrir" servindo inclusive de imagem para como Hegel o lê. Antes de ter sido descoberto por Kant, o entendimento era utilizado acriticamente ou, no vocabulário hegeliano, de maneira não autoconsciente. Faltava, no seu uso, uma reflexão sobre o exato fato de que era ele quem era conclamado a agir toda vez que se buscava fazer filosofia ou ciência ${ }^{294}$. Em decorrência disso, toda a filosofia feita, apesar de ser uma abstração da realidade, necessariamente aparecia como sendo a verdade

\footnotetext{
293 HEGEL, 1992, p.51.

${ }^{294}$ No sentido corriqueiro desse vocábulo.
} 
maior acerca da realidade sobre a qual versava. Uma vez que não sabe as condições de possibilidade de seu conhecimento, pois não é dela cônscio, o filósofo passava a acreditar nas abstrações que fazia como se verdades essenciais sobre a coisa fossem. Colocava, assim, seu pensamento no lugar da própria coisa sem sequer notar que o fazia. Embora descobrisse, nesse processo, parte da verdade, a sua acriticidade impedia que percebesse a inadequação entre a proposição e o real, posto julgar a inadequação como um problema da realidade e não da teoria.

A reflexão kantiana, nesse sentido, desnuda e desmonta as possibilidades de um tal conhecimento ser pensado de maneira imediata como o era até então, ainda que seu autor se mantenha dela prisioneiro ${ }^{295}$. A introdução da mediação ou, antes, da reflexão acerca da mediação efetuada pelo entendimento, abre a possibilidade de esse mesmo entendimento deixar de ter o poder de necessidade coercitiva sobre o pensamento e, ao mesmo tempo, a despeito de Kant, introduz uma possibilidade outra de pensar, que é aquela mesma explorada, mas nunca desenvolvida, em suas antinomias. Se é bem verdade que toda a introdução da Fenomenologia contém uma gigantesca crítica ao procedimento kantiano de primeiro avaliar e examinar os instrumentos do saber de modo a "antes de abordar a Coisa mesma precisa primeiro pôr-se de acordo sobre o conhecer"296 , o próprio fato de que o livro efetivamente tenha sido inicialmente escrito a partir dessa crítica - afinal, o Prefácio vem depois - já aponta que é somente a partir dele e de sua crítica que o pensamento hegeliano pôde começar. Daí que seja apenas a partir do deslocamento kantiano e do descolamento entre o instrumento de conhecer e o conhecimento mesmo que Hegel possa iniciar sua dialética, algo que reconhece mais de uma vez. ${ }^{297}$

Uma outra característica do entendimento descoberta por Kant é a maneira pela qual um certo formalismo entra em circulação como possibilidade mesma do pensar e, até mesmo, como seu mais alto grau. Uma vez que a abstração da mobilidade da realidade em detrimento da estaticidade do pensar é o procedimento padrão do conhecimento pelo entendimento ${ }^{298}$, fica fácil também introduzir um grau de

\footnotetext{
${ }^{295}$ Vide sua aposta no entendimento, não na razão.

296 HEGEL, 1992, p.63.

297 Tanto a Lógica quanto a Enciclopédia possuem observações sobre esse tema.

${ }^{298}$ O que Hegel reiteradas vezes chama de abstração.
} 
formalismo, posto ser a forma algo que pode dar conta de qualquer conteúdo. Outra forma de dizer isso é apontar como toda qualidade é redutível às quantidades, e.g. cor é uma tradução de um número $\mathrm{x}$ de frequência ou a medida um quilo não se importa com o fato de medir cobre ou plumas.

A consequência maior disso é que uma série de características e termos externos ao objeto estudado são introduzidos na explicação de seu automovimento como se pertencentes a ele fossem ${ }^{299}$. Externos, porque são constructos racionais humanos que são pensados como se independentemente operassem. Com isso, Hegel situa uma série de leis, padrões, energias, forças, etc. como comparecendo na explicação de uma situação concreta como uma falsa descoberta. Se, por um lado, como uma tal se apresenta, no fim das contas, não é mais do que projeção do pensamento por sobre a realidade. Tentando fugir da abstração e da projeção da razão sobre a realidade, o que seria mesmo o movimento de conhecer a realidade, Kant e o entendimento acabam por introduzir uma das maiores projeções da razão sobre o real. A crítica a Kant é, aqui, instrutiva:

O conceito da ciência surgiu depois que se elevou à sua significação absoluta aquela forma triádica que em Kant era ainda carente-deconceito, morta, e descoberta por instinto. Assim, a verdadeira forma foi igualmente estabelecida no seu verdadeiro conteúdo. Não se pode, de modo algum, considerar como científico o uso daquela forma [triádica], onde a vemos reduzida a um esquema sem vida, a um verdadeiro fantasma A organização científica [está aí] reduzida a uma tabela ${ }^{300}$.

"Reduzido a uma tabela" quer aqui dizer: reduzido a uma lista puramente formal, inerte e distanciada de como as coisas de fato são. Uma lista absolutamente abstrata, portanto. Hegel aqui está apontando para a impossibilidade que a crítica kantiana tem de juntar os termos que separa, precisamente porque esquarteja a razão em três partes que pouco se comunicam. Cria, com isso, uma dificuldade de junção posterior exatamente porque já começa tratando as coisas já demasiado apartadas e distantes. O formalismo, consequência da obra de Kant, consequência da utilização exclusiva do entendimento, se mantêm sendo um subjetivismo que isola o sujeito das práticas cotidianas (dos terrenos da ética e da política, portanto) e da realidade que

\footnotetext{
${ }^{299}$ HEGEL, 1992, p.48.

${ }^{300}$ Ibid., idem, negrito nosso.
} 
antecede os juízos de conhecimento. Falha, assim, em se dar conta do caráter de formação inerente ao humano, único ser que pode dizer eu e se captar nessa elocução. Um tal enunciado só é possível pelo fato de que o humano desenvolve uma autoconsciência que o permite se diferenciar tanto dos animais não humanos, quanto de seus semelhantes. Ignorar o surgimento dessa autoconsciência é ignorar o terreno existencial no qual operam os juízos de conhecimento sendo eles, portanto, posteriores.

Para Hegel, Kant falha, também, por desconsiderar que a existência humana normatizada por certas leis e pela comunidade ${ }^{301}$ antecede e gera o sujeito do conhecimento e que só a partir do primeiro termo se pode ter o segundo. Porque isola as partes e faz com que a razão prática e a pura sejam aplicações distintas da razão, uma conceitual e outra não, Kant não conseguiria conceber a maneira pela qual uma atitude pode determinar uma epistemologia e uma ontologia ou pode ser determinada por elas. Em outras palavras, a maneira de conceber o mundo é, também, informativa da maneira de agir nele, sendo ambas as partes entremeadas. É justo nisso que Hegel incide, por enxergar um déficit nesse aspecto da filosofia kantiana, daí outro motivo para classificar a divisão kantiana de morta.

Se o leitor nos acompanha até aqui, certamente notou que tudo o que foi exposto parece ter um aceno a uma junção de certa filosofia e certo comportamento, como se a ontologia (ou, hegelianamente, a logica) não fosse apenas conhecer objetos da realidade, mas fosse uma forma de se portar frente a ela. Uma vez que o homem é formado em sociedade, ou seja, que o desenvolvimento em comunidade é necessário (lembremos do duplo sentido de Bildung, cultura e formação) para que se possa dizer eu, é pressuposto que essa também informará a maneira pela qual o homem busca conhecer a realidade, i.e., uma sociedade formará o homem para certa ontologia e certa epistemologia necessariamente.

Isso porque, como vimos, quando Hegel introduz a noção de formação, ela altera fundamentalmente a possibilidade de se pensar a verdade, posto que agora ela será uma verdade que terá suas possibilidades delimitadas pelo seu horizonte histórico de pertinência. A formação delimitará um campo a partir do qual certa compreensão

${ }^{301}$ Essa é outra forma de dizer que Kant é formalista e que Hegel compreende seu formalismo como tautológico e vazio. Cf. a esse respeito o seguinte texto: MÜLLER, 2011. 
poderá adentrar ou não o escopo de sentido de determinado indivíduo e, de maneira mais expandida, de determinada época. Sendo assim, para pensar um campo de sentido e uma ordenação lógica de pensamento de cada época (o que poderia se chamar história das ideias), é necessário ver como esse horizonte formativo impacta a maneira pela qual a ontologia- ou a teoria do conhecimento - é concebida pelos filósofos.

A título de exemplo, se é verdade para Hegel que a filosofia kantiana tem por mérito radicalizar o pensamento sobre o sujeito e sobre a autoconsciência, é igualmente verdade que por seu procedimento efetivo, i.e., a maneira pela qual ela executou isso, ela carece da capacidade explicativa necessária a qualquer filosofia que se pense como sendo capaz de pensar a ligação entre realidade social e realidade humana, entre razão prática e pura. Ao se voltar para o sujeito transcendental, Kant descobriria a razão e o entendimento e seus modos de funcionar e, ao escolher o último, forneceria uma fundamentação para que a filosofia continuasse funcionando com os mesmos pressupostos que desde o início da modernidade trabalhou ${ }^{302}$. Uma tal escolha significa escolher entre as antinomias da razão e a apreensão conceitual do entendimento. Ao desistir das antinomias por considerá-las insolúveis, Kant teria, aos olhos de Hegel, aberto uma possibilidade de se descobrir a estrutura da razão e o caminho da verdade, mas teria escolhido o entendimento.

Hegel, lendo Kant, tenta executar o mesmo movimento crítico que seu antecessor, mas de maneira ainda mais expandida. Seu caminho só se torna possível porque Kant o pavimentou, então algum deslocamento ele promoveu; ao mesmo tempo, esse deslocamento ainda tentaria salvar, na noção de coisa-em-si, uma objetividade para além da participação do sujeito cognoscente. Tentaria, assim, manter o pressuposto de que existiria uma coisa sem que ela fosse coisa-para-alguém ou fenômeno. Isso é lido como uma última tentativa de salvar a noção de verdade e de finitude posto que, apesar de vetado seu acesso, a coisa-em-si ainda existiria. Para Hegel, dizer que algo existe, mesmo que esteja vetado, é suficiente para que aquilo opere efeitos e revele pressupostos, como na introdução ele deixa claro. ${ }^{303}$

\footnotetext{
302 Pode-se arguir que salvo à exceção de Heráclito e Spinoza, Hegel via na filosofia um grande continuum quando a questão era introduzir o pensamento sobre o movimento na filosofia.

${ }^{303}$ HEGEL, 1992, pp.63-69.
} 
Já quando se debruça sobre a moral, mantém inalterado o edifício epistemológico, como se o convívio com outros homens fosse de todo vivido de uma maneira muito similar àquela que se vive a vida do espírito. Mais do que isso: em nada a moral (leia-se, a convivência entre os homens) é capaz de alterar a maneira pela qual o conhecimento é concebido, sendo o objeto transcendental desse terreno das Gute, um bem que não se confunde em nada com o bem estar ou com algo empírico. Uma estrutura similar, embora não igual, é mobilizada, de modo que a vida empírica é, novamente, julgada desde o ponto de vista transcendental, por ser ele anterior e universal à própria experiência moral (e, aqui, o papel da educação, esforço empíricoefetivo do homem para se formar, em Kant é só o de reforço da consciência moral que o homem já tem) $)^{304}$.

Ora, toda a Fenomenologia faz seu arco partindo do indivíduo isolado, inicialmente tentando estabelecer relações de conhecimento com objetos que julga conhecer imediatamente - tal e qual expusemos no capítulo dois; vai em direção à socialização desse mesmo indivíduo e ao seu reconhecimento gradual da necessidade de uma análise de sua formação (Bildung) histórico filosófica para que ele compreenda o que, de fato, é necessário para um ato de conhecimento que ela julgava efetuar nos três capítulos iniciais da obra. É, portanto, uma descoberta do horizonte social necessário a um ato de conhecimento ou, se se preferir, uma descoberta do que existe de social no que se chama de individual.

Se o reconhecimento do peso da historicidade e da comunidade no processo de formação do homem é o objetivo final da obra, é consequente que ela comece por justo criticar a situação contrária de maneira performativa. É por isso que os capítulos que vão de um a três demonstram as falhas de uma consciência que tenta conhecer seu objeto, especialmente quando o faz sem conhecer sua própria formação, o duplo sentido proposital apontando tanto para a formação do objeto quanto do próprio sujeito do conhecimento. É também por isso que o capítulo quatro inicia por dizer termos chegado à "terra pátria da verdade" quando chega à SelbstBewusstsein ${ }^{305}$. Chegando ao ponto da reflexão da gênese do indivíduo e de sua capacidade de se tornar uma consciência

\footnotetext{
${ }^{304}$ FILHO, 1997.

${ }^{305}$ HEGEL, 1992, negrito nosso.
} 
de si, Hegel vê-se como capaz de chegar finalmente ao centro da questão, ao ponto fundamental da alienação do indivíduo à alteridade, aspecto de todo intocado nas filosofias anteriores, incluindo naquela de Kant.

Isso porque uma tal alienação já é pressuposta para que se possa falar em um terreno social. O homem se forma, necessariamente, a partir de uma língua que adota, de pensamentos que aprende, de comportamentos que são respostas e assim sucessivamente. Hegel é extremamente sensível a isso, a ponto mesmo de fazer com que a gênese da consciência-de-si seja a interação espelhada entre duas consciências, de modo que uma capitule da briga de morte e a outra não. É porque ambas sentem o estremecer da morte, mas apenas uma o teme que a dialética entre elas se torna dialética do senhor e do escravo (ou servo, Knecht).

Vai daí que para que a filosofia de Kant se assente no entendimento como estrutura fundamental do conhecimento racional e o mais próximo que o homem pode chegar do verdadeiro, ela precisa desconsiderar de todo a existência empírica do homem, ou seja, seu caráter de vivente numa realidade específica, circunscrita a um tempo histórico e a uma realidade social específicos. A função exclusiva do eu empírico precisa ser reenviar para o sujeito transcendental suas percepções a partir do seu posicionamento próprio. Pois se o eu empírico tivesse mais espaço de atuação, ele perturbaria o exercício da reta razão na operação do conhecimento. Trocando em miúdos, se o sujeito transcendental fosse formado e não uma estrutura, ele guardaria marcas da sua formação e, portanto, o sistema kantiano precisaria levar esse aspecto em conta.

Não é o caso, como sabemos, para Kant. Por mais que no texto sobre o esclarecimento Kant reflita sobre o tempo histórico ${ }^{306}$ é ainda desde um ponto de vista de um texto menor que o texto sobre o esclarecimento é cunhado e é, também, do ponto de vista do destaque do homem como um indivíduo, não como formado socialmente. Em português claro, a reflexão sobre o esclarecimento não é uma das Críticas, nem

${ }^{306}$ KANT, 1985. Mesmo aqui o começo célebre do texto ressalta bem o quanto essa era uma resposta de Kant que isolava o homem ainda mais da sociedade, tomando-o primordialmente como um indivíduo. Afinal, se o esclarecimento é "a saída do homem da menoridade", esta é exatamente definida como "incapacidade de fazer uso do seu entendimento sem a direção de outro indivíduo" (KANT, 1985, p.100). Resta clara a distância disso para Hegel, autor que critica, em carta a Niethammer, a estultícia que é a ideia de "pensar pela própria cabeça". 
tenta fundar o homem na sociedade, esta antecedendo aquele. O texto é visto e escrito por Kant apenas como uma resposta de jornal a uma pergunta ali feita, uma oportunidade pedagógica para um filósofo educar sua época, nada além. A reflexão sobre o presente e sobre o tempo histórico vivido, nesse sentido, ocupam mais um interesse secundário do que a centralidade de seu projeto crítico, precisamente porque também esse é o lugar da história e da concreção.

Não é à toa que o sujeito do conhecimento, da moral ou do juízo kantianos é o sujeito transcendental, despido de quaisquer subjetividades particulares ou singulares que o animem ${ }^{307}$. Com isso, a vida em sociedade não pode ser vista como uma característica fundamental (no sentido formativo e não como "parte" da vida) ao homem, tampouco sua época histórica. São antes vividas desde os horizontes do imperativo categórico ou dos conceitos, a única necessidade de viver em meio aos homens advindo da faculdade de julgar. Esse, outro motivo pelo qual Hegel pôde equiparar as Kritik a uma tabela morta, inerte: longe de falar de um ser social empírico, real, às voltas com as questões da sua época, Kant descreve um sujeito transcendental que, a crer nele, pode muito bem se mostrar a qualquer época de maneira indistinta daquela que Kant vive. Porque busca descrever a estrutura da razão e, ainda que o faça assentado em características sumamente modernas ${ }^{308}$, Kant desconhece ou ignora a importância do caráter histórico de sua empreitada. Esse o motivo pelo qual se vê como resolvendo o escândalo da filosofia de ela não ter ainda fundamentado o mundo racionalmente: o problema não decorre nem descende de uma forma específica da existência humana e de sua configuração na história do mundo, mas é um problema não resolvido de uma disciplina que fornece juízos adequados à realidade externa ou, em suma, juízos corretos e verdadeiros ${ }^{309}$.

${ }^{307}$ Poder-se-ia arguir que o belo tem ao menos uma característica singularizante, posto ser singular o objeto que cada indivíduo vai ter como propulsionador do livro jogo do entendimento com a imaginação. Em algum grau, verdade. Todo caso, para que haja belo é preciso que haja sempre, além do referido jogo, desinteresse. A universalidade e não mutabilidade das características já apontam sua ausente historicidade.

${ }^{308}$ Essa a razão que levará tanto Lacan quanto Adorno a colocarem Kant ao lado de Sade. Desde os prismas distintos de cada autor, comparece como verdade o fato de que último faz o mesmo que o primeiro em termos de pensamento, sendo sua contraface perversa.

${ }^{309}$ Podemos sempre argumentar a partir do texto “O que é o esclarecimento?”, especialmente a partir da leitura de Foucault - que encontra ali uma ontologia do presente - que Kant inicia um movimento de se pensar a modernidade. Mas frente ao edifício das três grandes críticas e da 
Alerta a uma tal ahistoricidade, Hegel toma o pensamento sobre homem de Kant em sua dimensão histórica, ou seja, deixa claro que para que a crítica kantiana seja capaz de dizer sua verdade, ela precisa ser tomada a de uma forma dupla: pelo que diz e pelo que significa em seu tempo, mas "não que o saber da verdade da coisa passe pelo saber do que dela se disse: um e outro estão enredados" ${ }^{310}$. Descobrir o que Kant disse e como seu tempo absorveu o dito são descobrir uma e a mesma coisa, posto que não interessa a Hegel os anacronismos nem os perspectivismos. Inscrever no tempo um discurso filosófico é, indiretamente, já cortar sua possibilidade de querer ser o discurso final sobre o mundo, vez que já mostra que existe um metadiscurso que é capaz de situá-lo numa narrativa. Em outros termos, historicizar uma filosofia já é remover seu caráter abstrato e suas tentativas de ser a única filosofia. Eis o procedimento de Hegel, por isso pode ora ressaltar o caráter de falsidade do pensamento kantiano - na medida em que busca ser o derradeiro pensamento sobre a razão - ora exaltar o entendimento como a potência mais grandiosa.

Mas isso não é tudo. Há ainda o movimento muito comum de Kant de manter a dimensão representativa, algo que até aqui em nosso texto ficava intuído, mas não explícito. Será isso que permitirá a Hegel fazer o "salto" do entendimento à Razão. Afinal, o entendimento não será outra coisa que "a Razão sob o reino da Representação"311, motivo pelo qual o entendimento é fundamental, mas ainda incompleto para o que Hegel almeja explicitar. Seu trabalho (o do entendimento) é exclusivamente abstrair e quando executa essa tarefa, está em plena posse de seus direitos e no uso típico de seu poder - mas, porque tenta ir além, acaba recaindo em vaidade. ${ }^{312} \mathrm{O}$ problema, então, é que o entendimento quando raciocina "é a liberdade [desvinculada] do conteúdo" e dele exige-se "o esforço de abandonar tal liberdade; em vez de ser o princípio motor arbitrário do conteúdo, mergulhar essa liberdade nele, fazer que se mova conforme sua própria natureza"313. O entendimento para ali mesmo

fundamentação, O que é o esclarecimento? tanto enquanto texto como enquanto questão, recebeu de seu autor um tratamento secundário.

${ }^{310}$ LEBRUN, 2000, p.116.

${ }^{311}$ LEBRUN, 2000, p.74.

312 HEGEL, 1992, p.54.

313 Ibid, idem. 
onde produz uma abstração porque se sabe jogando consigo mesmo e o que Hegel busca é justo um retorno ao movimento das coisas tal e qual elas se apresentam.

"Movimento", dissemos e repetimos mais de uma vez ao longo deste trabalho. É que a filosofia hegeliana só se permite expressar com termos que indiquem que a mobilidade outrora contingente se tornou mobilidade lógica, mas manteve-se móvel ainda assim. Não à toa Hegel falará que "o que importa no estudo da ciência é assumir o esforço tenso do conceito" 314 , ou seja, o que importa à ciência filosófica que Hegel propõe é se dar conta de que apesar da contingencia ser o que cai do conceito, ela também é importante em sua composição, uma vez que o conceito é também concepção de algo e não sua mera representação. Dizer que "a contingência cai do conceito", conforme dissemos, significa o seguinte: toda vez que o espírito realiza sua autorreflexão, toda vez que a história filosófica se delineia, ela se faz retirando a dimensão contingencial, ou seja, a possibilidade de poder ser outro ou ser passagem, daquele termo sobre o qual a reflexão é feita. A contingência impediria a presença do conceito porque ela é apenas possibilidade, ao passo que o conceito é apenas nexo de necessidade. No conceito não há acaso, nada é fortuito; na contingência só há acaso e tudo é fortuito, razão pela qual Hegel a atribui ao pensamento, mas sobretudo à natureza, que é dita ser o reino da contingência pura. ${ }^{315}$

Fica claro porque ela deve cair do conceito: no conceito há apenas necessidade, não é possível que algo possa ser completamente outro ou não ser por razões de acaso. Isso porque algo se concebe e se faz de determinada maneira, o conceito apenas acompanhando seu movimento lógico, buscando mesmo ser a verdade e o espelho de seu automovimento. Se representação fosse, à coisa de adequaria ou, mais hegelianamente, a coisa se adequaria; como é a própria descrição da lógica do real, à coisa acompanha.

Como Razão e entendimento possuem relações de irmandade, diferindo apenas em campos de aplicação, será através deste que aquela será alcançada. Um dos caminhos privilegiados para essa crítica é a linguagem ou, mais especificamente, as

\footnotetext{
${ }^{314}$ Ibid, p.53, negrito nosso, itálico do autor.

315 Para uma discussão detida disso, Cf. HENRICH, 1990.
} 
proposições. Hegel diferenciará entre atitude e proposição raciocinantes e atitude e proposições especulativas. Vejamos como a linguagem incide aí

\subsection{A atitude raciocinante}

Um dos primeiros aspectos que chama a atenção na reflexão hegeliana sobre a atitude raciocinante é justo a maneira de nomear: atitude raciocinante (Räsonieren ${ }^{316}$ ) não diz respeito apenas à maneira pela qual um indivíduo constrói uma série de proposições com valor de verdade variável ou com capacidades distintas de compreender o real, mas diz sobretudo respeito a um posicionamento existencial que tem ecos epistêmicos. Essa dimensão existencial, portanto, é o que que motiva a construção de proposições que são, ao fim e ao cabo, apenas inversões e destruições do conteúdo que se tem a frente. Vai daí que Hegel aponte que:

$\mathrm{Na}$ atitude raciocinante, dois aspectos devem ser ressaltados aspectos segundo os quais o pensamento conceitual é o seu oposto. De uma parte, o procedimento raciocinante se comporta negativamente em relação ao conteúdo aprendido; sabe refutá-lo e reduzi-lo a nada. Essa intelecção de que o conteúdo não é assim é algo puramente negativo: é o ponto terminal que a si mesmo não ultrapassa rumo a novo conteúdo, mas para ter de novo um conteúdo, deve arranjar outra coisa, seja donde for. E a reflexão no Eu vazio, a vaidade do seu saber.

O deslocamento para a atitude (e que a tradução capta), ao qual já vínhamos aludindo acima, merece um esclarecimento. Nota-se, a partir desse movimento de Hegel, que não se trata mais de um pensamento que reflete sobre o mundo e busca desinteressadamente descobrir suas estruturas; antes, trata-se de um comportamento humano frente à realidade que dá a ela um destino muito específico, profundamente interessado nos possíveis desfechos de suas próprias ações. A mobilização, por Hegel, de uma categoria mais própria da reflexão ético-moral já mostra bem a antecedência

316 Uma tradução manteria o duplo sentido filosófico/leigo de Räsonieren seria "argumentação", posto argumentar ser o trabalho do filósofo, mas também o que se faz numa discussão/num debate no qual se tenta uma defesa de si ou uma anulação da predicação que o outro faz. Perderíamos, dado não sermos americanos, a noção de atitude, grosso modo presente no uso do vocábulo que faz Hegel. 
dessa faceta da vida para ele e, embora a mobilize a categoria num registro absolutamente distinto daquele que era o de Kant, é a partir dele - de sua crítica indireta, para sermos preciso - que ele a faz seu posicionamento. Dito de outro modo, é já a argumentação uma maneira muito específica de lida com as coisas, maneira essa que torna negativa toda validade do conteúdo e como que o invalida a partir de seus próprios pressupostos. Os pressupostos que deviam ser capazes de guiar de maneira reta e precisa em direção a um caminho se mostra ambíguo e capaz de uma interversão no oposto daquilo que o pressuposto lança como expectativa.

Há aí também uma alusão a um certo tipo de comportamento que está circulando em seu tempo. Queremos dizer com isso que a imersão da teorização hegeliana nos tempos históricos e, nesse caso, em sua própria época, também já serve, em algum grau, como crítica à posição tida como abstrata encontrada em Kant. Não é aí apenas uma teorização acerca da maneira correta ou errônea de se portar frente ao mundo, tampouco é uma descrição das ocorrências do humor humano situado; antes, é uma descrição com pretensões gerais, mas que parte necessariamente das ocorrências históricas que são observadas. Especificamente esse momento da Fenomenologia corresponde ao estudo, feito por Hegel, da obra francesa $O$ sobrinho de Rameau ${ }^{317}$, em tradução feita por Goethe ${ }^{318}$.

A peça se divide entre dois personagens: $\mathrm{Eu}(\mathrm{Moi})$, que representa Diderot, e Ele (Lui), que representa o sobrinho de Rameau, músico famoso. Eles se alternam num diálogo ora satírico, ora sério, sobre ética, a sociedade e as expectativas de reconhecimento social que animam a época. Os tópicos, assim, têm por eixo comum uma certa maneira bífida de apresentar as teses: aquela que seria a "mais moralmente

${ }^{317}$ Curiosamente, essa não vai ser a única vez que Hegel dialogará com Diderot a partir de uma obra deste. A forma explícita de diálogo, embora algo crítico, é escrever uma Enciclopédia, embora em nada parecida com a do autor francês. Deslocou pressupostos, execução e conteúdo, mas manteve o nome, como que retificando dialeticamente os erros filósofo francês posto que, ao conservar o nome e mudar o conteúdo, mantém parte do projeto, mas o refaz ao seu modo.

318 Importante ressaltar uma curiosidade histórica que nos permite reafirmar o caráter universal e não germanófilo da filosofia hegeliana. É sabido que a obra referida foi primeiro publicada em alemão na tradução de Goethe em 1805 e só mais tarde, em 1891, publicada em francês a partir do manuscrito encontrado do autor. Assinalar isso serve para mostrar que Hegel se utiliza de uma obra francesa por seu caráter revelador de uma realidade comum entre a França e a Alemanha, a saber, a posição daquilo que mais tarde viria a ser conhecido, nos debates posteriores, como intelectual, figura remunerada por seu esforço mental e que tem pretensões módicas, dada a realidade vivida, de estabelecer uma república de letrados 
correta" e aquela que, partindo dos mesmos pressupostos, chega a conclusões absolutamente distintas. A apresentação do falso como algo que circula de maneira igual à verdade no campo social, aqui, faz com que o próprio verdadeiro seja posto em xeque, vez que seu substrato, ligado que está às noções de verdade como correspondência, é incapaz de fornecer os elementos para sustentar uma negatividade tal e qual a apresentada. Hegel se aproveitará disso para cunhar a consciência honrada, que busca fazer circular a verdade, mas desconhece seu próprio cinismo e a consciência dilacerada, que é marcada pelo cinismo, mas tem uma nostalgia da honra como seu horizonte.

É com base nisso que as reflexões que Moi e Lui fazem sobre a sociedade servem de esteio para as próprias reflexões de Hegel sobre a atitude raciocinante. Afinal, o que acontece na obra, em termos hegelianos, é que o personagem Ele acaba por fazer uma apresentação da negatividade inerente aos conteúdos morais e da ação a partir do uso que faz de seu entendimento para reduzir os conteúdos a nada. Em outros termos, o que a personagem Ele mostra é a potência do negativo presente no entendimento que se mantém oculta para a consciência honrada, que também dele se serve. Como a negação apresentada é abstrata, a personagem falha em construir outras possibilidades e se mantém como que um nostálgico da identidade, como se ele ainda contasse com os pressupostos que tenta criticar $^{319}$. Outra forma de dizer isso é que ele usa a negatividade do entendimento, mas mostra a falha no seu uso exclusivo quando um tal uso não visa alterar os pressupostos a partir da negatividade que o anima.

Cabe ressaltar que Hegel, aqui, tem um alvo que reaparecerá ainda algumas vezes ao longo do Prefácio e perpassará boa parte do capítulo seis: os românticos e sua ironia. Pois o uso da ironia para Hegel não é tomado como uma simples forma de acesso ou lida com o conhecimento, tampouco como figura de linguagem em sentido fraco ${ }^{320}$. Por ser lida como uma maneira de servir-se do entendimento de modo a fazê-lo a tudo destruir, a ironia é analisada e diagnosticada como uma figura problemática da negatividade, vez que jamais consegue produzir uma negação determinada, ou seja, o uso produtivo do negativo em direção a outra coisa que surgiria a partir da morte da

\footnotetext{
319 SAFATLE, 2007.

${ }^{320}$ SAFATLE, 2007.
} 
primeira. Os usos do entendimento, nesse sentido, se restringem à produção de negações abstratas, o que significa dizer que apenas se tem a ausência do que se afirmou, a destruição absoluta do termo primeiro e a impossibilidade do progresso em direção a qualquer pensamento ou desenvolvimento ulterior.

Por ser uma característica encontrada num cínico moderno como Diderot, mas observada por Hegel nos românticos ${ }^{321}$. Isso permite a junção do cinismo com a ironia romântica para Hegel, posto que para ele também os românticos circulam numa gama de pressupostos ainda que falem contra eles. Quer isso dizer que se a personagem Ele é um cínico, ele o é na medida em que ironiza condutas, ironia sendo a exata figura eleita pelos românticos para apresentar o que pensam da filosofia ${ }^{322}$.

É evidente que Hegel toma os românticos, especialmente a Schlegel, a partir de sua própria filosofia, e não tanto a partir dos pressupostos dos próprios autores, sendo então muito mais uma leitura da filosofia hegeliana do que da posição romântica por $\mathrm{si}^{323}$. Mas isso não invalida uma tal leitura. Antes, a circunscreve em um campo específico, qual seja, aquele que busca apenas delimitar o efeito que certos usos da linguagem geram, bem como qual o campo ou o horizonte que produz a possibilidade de tais usos. Em outras palavras, um campo que compreende, a partir dos pressupostos de leitura de Hegel - o maior deles, a formação e seus efeitos - as coordenadas a partir das quais o romantismo é possível e para o que eles apontam quando produzem sua filosofia.

Em termos de efeito numa sentença, a figura de linguagem da ironia serve de modelo, mas não esgota as possibilidades da ironia romântica ${ }^{324}$. No seu uso linguístico, quando faço uma declaração e dela se capta sua dimensão irônica, a única coisa que se pode captar é que o que foi dito não está exatamente na valência em que foi colocada. Só se sabe, então, que a sentença não pode nunca corresponder de maneira precisa a si mesma e àquilo que ela busca dar a entender a partir da concatenação das

321 Sobre a justeza desse diagnóstico, Cf. o prefácio de Márcio Suzuki ao Dialeto dos fragmentos, livro de coletânea de fragmentos que organizou, constante na bibliografia e também SUZUKI, 2007. Cf. ainda NANCY, 1988; Cf. também ANDRADE, 2011.

322 SCHLEGEL, 1997, pps 26-28. Neste último, a ironia é a apresentada como "forma do paradoxo" em um dos fragmentos, e este último como tudo que é, "ao mesmo tempo, bom e grande".

${ }^{323}$ SAFATLE, 2007.

${ }^{324}$ SAFATLE, 2007. 
palavras em direção a um sentido. Isso se faz, precisamente, porque a ironia impede que a frase seja capaz de chegar ao seu pleno sentido: ela se implode no momento em que seria capaz de adquiri-lo, sua conclusão acaba sendo não sua inteligibilidade, mas sua destruição. A ironia executa uma mortificação na operação do sentido, de modo que a frase se desmancha no momento mesmo em que é proferida.

Por si só, a ironia aplicada às sentenças que têm por objetivo o conhecimento o campo epistemológico, portanto -, já seria problemática, postos que aquilo a que elas se referem e o que elas buscam iluminar se eclipsaria no momento em que a frase chegasse a seu fim. Seria virtualmente impossível aprender qualquer coisa, posto que tudo poderia ser não tanto o contrário do que se diz, mas outra coisa de todo. No plano ético, a coisa é ainda pior: este se torna interditado, vez que a dimensão objetiva de qualquer frase se dissolve na exata consumação da sentença. O término de uma frase é, ao fim e ao cabo, sua subversão, posto ser sua chegada ao avesso de si mesma. Mas não apenas as frases e sentenças: especialmente os comportamentos seriam problemáticos, já que o indivíduo nunca estaria ali bem onde parece estar, parece sempre fazer outra coisa que não aquilo a que parece aderido. Sendo esse o horizonte se torna impossível, então, estabelecer um plano ético que seja irônico, justo porque a ironia não estrutura nada de positivo: movediça que ela, é apenas a presença pura do negativo que nunca transcende em direção a nada ${ }^{325}$. É, em suma, uma nadificação que dá em nada.

Uma figura do negativo que é incapaz de se movimentar tanto porque acaba por destruir precisamente aquilo que faria o movimento seguir adiante, quanto porque acaba por ensimesmar o sujeito é o exato oposto da figura de negatividade como movimento que Hegel está buscando. O ensimesmamento é menos evidente, mas se torna evidente se pensarmos que a circulação dos comportamentos e sua leitura se tornam impossíveis desde um ponto de vista social. Não há a possibilidade de reconhecer a aderência real de um indivíduo a nada, posto toda aderência já ser uma manifesta ironia frente àquilo a que adere. É justo a isso que nosso suábio chama de "vaidade" frente ao conteúdo: uma vez que não existe nenhum tipo de conteúdo que

\footnotetext{
${ }^{325}$ Nessa nota, uma obra como Crítica da Razão Cínica, de Sloterdjik, explora essa dimensão contemporânea da existência irônica de maneira profunda.
} 
sustente o negativo, nada que confira um fundamento, nada que nem sequer sobre do conteúdo ironizado, apenas o Eu que sobre o conteúdo reflete sobressai, sendo ele quem caminha livremente pelos conteúdos e apesar deles. O indivíduo se superinfla frente à realidade e passa a agir como se pudesse controlar a realidade e modifica-la a partir dos pressupostos que julga corretos ${ }^{326}$.

É fácil observar a diferença entre uma negação como a hegeliana, que tem o negativo como motor, mas não como fim, e a negação abstrata, que destrói tudo de maneira definitiva desde o uso da ironia. Uma tal facilidade é igualmente proporcional à dificuldade de notar a semelhança vislumbrada por Hegel entre as duas figuras, i.e. a sua e a dos românticos, uma vez que ambas são figuras que estão visando destruir os fundamentos, tido como falsos, a partir dos quais se erigem. A diferença central, para Hegel, é que a atitude raciocinante se mantém presa aos pressupostos e, exatamente por isso, pode destruir o conteúdo. É como se ela, respeitando e se mantendo dentro dos pressupostos kantianos, estivesse supondo uma coisa em si e se comprazesse em demonstrar a finitude $e^{327}$ dos fenômenos e sua capacidade de anulação destes a partir da apresentação de seu oposto. O oposto aqui, no entanto, não é a mera destruição da coisa no sentido de sua negação exterior, mas de sua negação interior. Ironizar uma conduta, nesse sentido, é fazer nela uma rachadura a partir de uma mimese perfeita, mas que apenas está sutilmente deslocada, não bem corresponde ao que deveria, etc. Como não há relação de necessidade entre adoção privada de certas condutas e aderência social a elas, a conduta é apenas a mimese irônica daquilo que apresenta.

Sabendo o que sabemos da visão de Hegel que junta Kant, os românticos e o cinismo moderno sob a égide de um problema multifacetado, mas de raiz comum, não nos parece ser acaso que Hegel escolha uma crítica para falar da Räsonieren: é porque ela, como crítica, apresenta a figura de passagem dialética de um ponto no qual a identidade ainda não perdeu seus fundamentos para um ponto no qual o negativo já se torna algo que circula, algo possível de ser manejado, ainda que seja unicamente dentro

${ }^{326}$ Não é difícil notar que toda uma dimensão protovanguardista, se encontra aqui contemplada. Ela é observada por Hegel, pois é ela que o faz afirmar que os romances de formação buscam "fazer um furo na ordem das coisas, modificar o mundo ou melhorá-lo" HEGEL, 2014, p.358. Isso é muito distante de um procedimento hegeliano de compreensão do mundo.

${ }^{327}$ BOURGEOIS, 2004. 
dos pressupostos da finitude. Nos parece por isso que a partir da leitura da obra de Diderot que Hegel faz, é possível afirmar algo como

Aliás, não é difícil ver que nosso tempo é um tempo de nascimento e trânsito para uma nova época. $\mathrm{O}$ espírito rompeu com o mundo de seu ser-aí e de seu representar, que até hoje durou; está a ponto de submergi-lo no passado, e se entrega à tarefa de sua transformação. Certamente, o espírito nunca está em repouso, mas sempre tomado por um movimento para a frente. Na criança, depois de longo período de nutrição tranquila, a primeira respiração - um salto qualitativo interrompe o lento processo do puro crescimento quantitativo; e a criança está nascida. Do mesmo modo, o espírito que se forma lentamente, tranquilamente, em direção à sua nova figura, vai desmanchando tijolo por tijolo o edifício de seu mundo anterior. Seu abalo se revela apenas por sintomas isolados; a frivolidade e o tédio que invadem o que ainda subsiste, o pressentimento vago de um desconhecido são os sinais precursores de algo diverso que se avizinha. Esse desmoronar gradual, que não altera a fisionomia do todo, é interrompido pelo sol nascente, que revela num clarão a imagem do mundo novo. ${ }^{328}$

Uma tal imagem, aquela mesma de um mundo em tudo diferente do anterior e que depende da compreensão de seu passado para que faça algum sentido, só é pensável porque sua dimensão política se faz ver com todo peso na destruição de todo ideal prévio à revolução. Uma tal destruição tem a liberdade por carro chefe (é a primeira palavra do lema, afinal) e lança o homem na ausência de solos seguros nos qual pode se manter. Isso desenraiza o homem de sua estabilidade, confrontando-o com a gratuidade de suas ações. Sendo assim, o homem sente o abalo de suas convicções e passa a fazer circular o negativo de sua liberdade, algo só possível porque existem as condições sócio políticas para tanto. É em torno de uma tal situação que a obra de Diderot está estruturada e é a ela que a obra apresenta.

Dito de outro modo, a crítica de Diderot (como a de Hegel) não é apenas uma crítica ao Iluminismo enquanto maneira de conceber o conhecimento, mas sobretudo uma crítica na maneira pela qual a liberdade, sem critérios, pode ser exercida das maneiras mais destrutivas, em detrimento do bom convívio, mas seguindo os pressupostos deste. É como se Diderot em sua sátira desnudasse, em algum grau, os

\footnotetext{
${ }^{328}$ HEGEL, 1992, p.26.
} 
desejos mesquinhos por detrás da aparente bondade da consciência honesta, uma tal honestidade sendo passível de ser lida como mero desejo de reconhecimento social e como uma outra forma de ironização de condutas, apenas inconsciente de seu caráter irônico ${ }^{329}$. Faz isso ao mesmo tempo em que mostra que o excesso de ironia do seu personagem cínico nada mais é do que uma forma muito sutil de apego aos mesmos ideais elevados dos quais tanto debocha.

Para Hegel, o compartilhamento com os franceses da ausência de raízes às quais o indivíduo possa se apegar é o que permite que o mesmo posicionamento frente a liberdade seja observado lá e cá, Jena e Paris. Se no Sacro Império a coisa toma a forma do romantismo e de suas requisições e necessidades de formar seu leitor na ironia, essa "forma do paradoxo", que por sua vez não é outra coisa do que "tudo aquilo que é ao

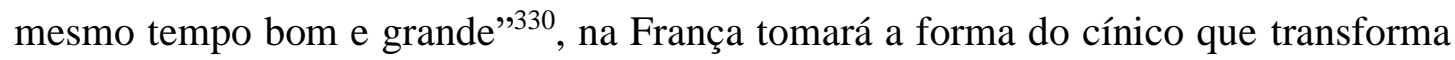
todos os pressupostos morais no seu oposto. Grosso modo, isso equivale a afirmar que ambos agem como se sempre adicionassem um “...ou não” ao fim de cada frase, de cada comportamento, de cada aderência. Com isso, todas as ações perdem a importância, posto estarem sempre circunscritas ao horizonte próximo de seu colapso. Isso gera, como esperado, uma impossibilidade de estruturação de uma vida social compartilhada, uma vez que a base desta é justo a expectativa e seu consequente cumprimento, a figura do contrato sendo o dispositivo jurídico com força legal para obrigar tais cumprimentos, sob pena de punição no caso de não atendimento do que foi nele acordado.

Ora, a dialética visa justo incidir na linguagem que se mantém enraizada na abstração e na essencialização identitária para demonstrar que a realidade é móvel e desenraizada, mas que isso não significa uma diferença irreconciliável entre a não identidade e identidade, posto haver uma maneira de estabelecer a identidade entre elas. Se Hegel busca fazer colapsar todas as certezas frágeis do entendimento - que não à toa são chamadas de abstrações - a partir das tentativas sempre falhas de sua realização, ele o faz na medida em que vê que o negativo pode conferir uma possibilidade outra de compreensão da identidade, possibilidade essa menos frágil do que aquela já atacada.

329 Daí Hegel dizer que a consciência honesta faz o que a outra, a dilacerada, também faz. HEGEL, 2000, pp.56-58.

330 SCHLEGEL, 1991, p. 28. 
A mobilização do negativo por parte dos que fazem uso da negação abstrata serve assim de propulsão ao entendimento para que o Espírito finalmente se dê conta de que sua realização no mundo se encontrará sempre embarreirada conquanto ele não se dê conta do papel de móbile - e somente de móbile - que o negativo desempenha.

Esse móbile, no entanto, tem de levar a algum lugar. Uma vez que tem o começo por fim, é possível para Hegel fazer duas coisas aparentemente irreconciliáveis: primeiro, definir, em sua Fenomenologia, o caminho filosófico como "caminho do desespero", precisamente porque o movimento não confere nenhuma segurança àquele que inicialmente por ele passa; e, ao mesmo tempo, criticar aqueles que usam o negativo como figura final do pensamento. Embora não pareça, a questão é mais complicada e profunda do que inicialmente parece. Afinal, o que garantiria que a dialética não seria apenas uma irmã gêmea da ironia se mesmo ao defini-la para seu interlocutor - Goethe - Hegel não se furtou de usar um mot de esprit irônico dizendo ser ela "o espírito da contradição organizada" "331 ? O que diferenciaria uma contradição organizada de uma contradição em desordem se é justo a contradição que é suposta de suspender e causar distúrbio em quaisquer ordenações?

Ora, o caminho do desespero já é uma imagem que ilustra que se busca chegar a algum lugar com ele e, sendo assim, o objetivo de Hegel é chegar justo de onde saiu, ou seja, do começo. A retomada do começo, já tendo passado pelo fim, é agora mediada por todo o caminho percorrido e já se sabe justificada. Nos deteremos de maneira mais atenta a isso no subcapítulo posterior, mas tenhamos em mente que a relação da dialética com a ironia, nesse sentido é de contraposição dialética ou, nas palavras do autor:

"na atitude raciocinante, dois aspectos devem ser ressaltados aspectos segundo os quais o pensamento conceitual é o seu oposto. De uma parte, o procedimento raciocinante se comporta negativamente em relação ao conteúdo aprendido; sabe refutá-lo e reduzi-lo a nada. Essa intelecção de que o conteúdo não é assim é algo puramente negativo: é o ponto terminal que a si mesmo não ultrapassa rumo a novo conteúdo, mas para ter de novo um conteúdo, deve arranjar outra coisa, seja donde for. E a reflexão no Eu vazio, a vaidade do seu saber." 332

\footnotetext{
${ }^{331}$ ARANTES, 1996, p.213.

332 HEGEL, 1992, p.54.
} 
A frase, apesar de direta - é um posicionamento frontal, aparentemente contrário à atitude raciocinante - divide a comparação em dois aspectos. A primeira parte do primeiro aspecto é justo aquele que vínhamos observando até aqui, da maneira pela qual a ironia - para Hegel, a figura negativa maior da atitude raciocinante - se mantém simplesmente reduzindo tudo ao contrário de si e ao negativo. O problema é desenvolvido e apresentado como tal de maneira um pouco mais rica logo adiante, quando Hegel diz que "uma vez que não ganha como conteúdo sua negatividade, essa reflexão, em geral, não está na Coisa, mas passa sempre além dela"333. Esse problema nos parece ser o eixo em torno do qual a obra de Diderot gira, ao menos para Hegel, de modo que uma análise de trechos da obra se torna, aqui, imperativo.

\subsubsection{O sobrinho irônico de Rameau}

O trecho sobre a ausência de ganho de conteúdo e do fato de passar ao largo da coisa, somado a um outro trecho da obra supracitada de Diderot, nos permitem bem ver o escopo do problema relativo à circulação do negativo. Na reflexão sobre a educação de sua filha de oito anos, o filósofo da obra de Diderot (a personagem $\mathrm{Eu}$ ) afirma que a educaria em todas as artes que encantam os sentidos. Dada a exata função das artes nas quais vai educar sua filha ser lida como o deleite das sensações, sua escolha de quanto tempo ela dedicaria a cada disciplina se limita à capacidade dessas obras de conferir habilidades muito práticas, fazendo com que as artes sejam legíveis apenas por sua função na formação. Essa função é o que poderíamos chamar de uma certa operacionalidade social, como se ela fosse educada apenas para ser boa cidadã e não tanto para aprender as artes. É, portanto, um desvio da arte de sua preocupação com o belo ou consigo mesma e uma utilização desta para s proveitos exclusivos do sujeito, proveitos esses medidos pelo quanto de circulação na sociedade um tal estudo das artes pode prover. Assim:

EU - Visto que a natureza foi tão ingrata para com ela, dando-lhe uma compleição delicada com uma alma sensível, e expondo-a às mesmas penas da vida, como se tivesse uma compleição forte e um

${ }^{333}$ Ibid, idem. 
coração de bronze, ensinar-lhe-ei, se puder, a suportá-las com coragem.

ELE - E deixai-a chorar, sofrer, ter dengos, ter os nervos irritados como os outros, desde que seja bonita, divertida e faceira. Como? Nada de dança?!

EU - Não mais do que o necessário para uma reverência, para um porte decente, para apresentar-se bem e para saber andar.

ELE - Nada de canto?

EU - Não mais do que para uma boa dicção.

ELE - Nada de música?

EU - Se houvesse um bom professor de harmonia, eu lha confiaria de bom grado, duas horas por dia, durante um ou dois anos, não mais. ELE - E no lugar das coisas essenciais que suprimis? ${ }^{334}$. Além disso, supõe ser boa ideia substituir o tempo ali dedicado para instruções "em gramática, fábula, história, geografia, um pouco de desenho e um pouco de moral" 335 .

Ouvindo essa ligação feita entre a dimensão de funcionamento social e educação estética, ou seja, uma espécie de utilização funcional da arte para o aperfeiçoamento do homem no seu convívio em sociedade, o sobrinho intervém. Notese que a primeira inversão vem justo do Eu (Diderot): ele inverte a expectativa que recorrer à arte causa, posto a arte não ser pensada pelo seu interlocutor como outra coisa do que o que há de essencial sendo, portanto, um fim em si mesma. O filósofo, por seu turno, o vê como algo cuja medição se faz pela utilidade e pelos ganhos práticos que seu estudo pode auferir ao estudante (boa dicção, bom porte). Esse era para ser, curiosamente, o pressuposto que o sobrinho (Ele) deveria adotar, posto ele enveredar por esse caminho na conversa ao exaltar que seu interlocutor deixe sua filha ter certas regalias caso seja "bonita, divertida e faceira". O próprio sobrinho se vê surpreendido quando seu interlocutor apresenta algo que poderia ser lido como cínico, mas de maneira séria: a utilidade sobrepujando a gratuidade e a beleza, a aderência sendo apenas semblante de uma aderência real.

Não existe, nesse sentido, diferença no tipo de posição que ambos ocupam, existe apenas momentos distintos e inciência de um sobre sua condição cínica e de outro de sua condição honesta. O filósofo (Eu) adota uma postura mais associada a uma suposta praticidade, buscando nas artes apenas o que julga necessário para bem se conduzir como membro da sociedade; o sobrinho, por seu turno, busca as artes pelo

\footnotetext{
334 DIDEROT, 2006, p.69.

335 Ibid, idem.
} 
seu poder de encanto, por sua produção de beleza e por ser algo essencial. Nesse primeiro momento, portanto, é a consciência honesta do filósofo que adota uma posição cínica e está inconsciente desta. Essa será uma posição similar a que adotará o Sobrinho quando de ações julgáveis por uma moral.

Notando a similaridade entre ambos, o sobrinho observa que a formação completa desejada para a filha do filósofo $(\mathrm{Eu})$ tem uma dificuldade insolúvel, a saber, aquela mesma inerente ao fato de que para ser bom professor, aquele que ocupa o cargo ou bem seria incapaz de fazê-lo pela idade (já que os que se dedicam exclusivamente ao aprendizado não ensinam e envelhecem sem ensinar), ou bem seria um mentiroso que não pode cumprir as expectativas que, no entanto, gera:

ELE - Ah! Voltamos ao ponto. Esses professores ${ }^{336}$, esperais que saberão a gramática, a fábula, a história, a geografia, a moral de que lhe darão lições? Conversa, meu caro senhor, conversa. Se possuíssem essas coisas o bastante para ensinar, não as ensinariam. EU - E por quê?

ELE - Porque teriam passado suas vidas a estudá-las. É preciso ser profundo na arte ou na ciência para bem conhecer os elementos. Os trabalhos clássicos só podem ser bem feitos por aqueles que envelheceram no ofício. O meio e o fim é que esclarecem as trevas do começo. Perguntai ao vosso amigo D'Alembert, o corifeu da ciência matemática, se seria capaz de ensinar seus elementos. Só após trinta ou quarenta anos de exercício meu tio entreviu os primeiros clarões da teoria musical.

EU - Ó louco, arquilouco! (gritei) Como é possível que em tua cabeça idéias tão corretas se misturem com tanta extravagância? ${ }^{337}$

A exasperação do filósofo frente à resposta de seu interlocutor mostra bem o efeito do tipo de inversão e redução à negatividade própria da ironia ou, dito de outro modo, o que a ironização das condutas de que fala Hegel pode causar naquele que ainda crê na sua conduta como decorrendo de uma adequação à certa verdade. Como não é mera resposta jocosa, mas uma incursão no cerne da argumentação, é impossível prosseguir se forem mantidos os mesmos pressupostos argumentativos e a mesma conduta inicial de simplesmente se guiar por um princípio de uma educação que trate a arte como mero instrumento útil. Revela fica a faceta meramente d encanto do outro

\footnotetext{
${ }^{336}$ Das matérias “sérias", listadas logo adiante.

${ }^{337}$ DIDEROT, 2006, pp.69-70, negrito nosso.
} 
da educação que o filósofo busca dar à filha. Isso porque, para que as matérias do espírito sejam de fato ensinadas, elas dependem de um aprendizado e de uma formação para a qual um professor do tipo que Diderot buscaria para sua filha é incapaz de possuir na idade suposta, por um lado; por outro e fundamentando o primeiro, só foi possível se descuidar porque as artes são pensadas como meios para fins, a aderência a elas transformando-as em meros instrumentos. Afinal, a adoção das artes na educação não será feita em benefício de tornar sua filha uma artista. Longe disso, visa apenas torná-la alguém que tem bom porte e boa dicção e algum domínio das matérias do espírito. De maneira sintética, é porque ele não acredita de fato numa formação artística ou intelectual que qualquer um pode ensinar para sua filha. É porque a questão da formação é secundária para ele que a formação dos professores a serem contratados não aparece.

Nesse caso, então, o que o Sobrinho aponta não é tanto que exista uma impossibilidade e que esteja fora de questão o ensino, mas que as realizações efetivas das expectativas do filósofo são contrárias à formação que ele busca pra filha. Vai daí, então, que a resposta irônica consiga reduzir o conteúdo das proposições do filósofo ao negativo: ela não introduz um negativo lá mesmo onde ele não caberia; antes, ela percebe o solo negativo dentro do qual a expectativa caminha e a faz colapsar na areia movediça que ela mesmo busca atravessar.

Isso só foi possível porque a questão da formação de sua filha e da utilização das artes para tal fim deu indícios ao sobrinho de que a preocupação do filósofo não era com aquilo mesmo que ocorreria com o aprendizado efetivo das matérias; este era apenas um verniz para sua real preocupação, a saber, a boa conduta de sua filha nos meios sociais. Estando todas as preocupações que se manifestam assentadas num polo que é necessariamente a negação daquele discurso que comparece de maneira direta, se torna muito simples para o sobrinho utilizar o que seria a realização correta das expectativas para demolir as certezas de seu interlocutor. A verdade é utilizada para mostrar que o que anima de maneira igual, tanto o filósofo quanto o sobrinho, não é mais do que uma expectativa de convívio social desde uma posição específica. Dito de maneira outra: quando a verdade comparece nas frases do sobrinho, é para mostrar de que modo toda ação e todo o direcionamento para "fábula, história, geografia" já se 
assenta numa compreensão da utilidade ${ }^{338}$ dessas disciplinas, não tanto nas realizações necessárias para atingir a verdade das mesmas. É assim, confrontado com a verdade de seu solo social, que o entendimento pode descobrir a negatividade inerente às suas ações. Nas palavras de Hegel:

A consciência honrada toma cada momento por uma essência permanente; e é inculta carência-de-pensamento não saber que ela também faz o inverso. A consciência dilacerada, ao contrário, é a consciência da inversão, - e na verdade, da inversão absoluta; nela, o conceito é o que domina, e que concentra os pensamentos amplamente dispersos para a consciência honrada. Por isso, a linguagem da consciência dilacerada é rica-de-espírito. ${ }^{339}$

A consciência honrada (que é o filósofo ou o $E u$, na peça) faz tudo cristalizar e se tornar imóvel demais, ao passo que a consciência dilacerada (o sobrinho ou o Ele, na peça) sabe da mobilidade do chão sobre o qual pisa e, por isso, nele não confia, fazendo com isso a certeza do outro vacilar porque ela provém de uma incultura sobre suas próprias ações, o que significa, em hegelianês, a impossibilidade de enxergar a identidade entre a identidade (ele mesmo) e a não identidade (o sobrinho), como se eles não estivessem executando a mesma ação. Um momento que fica clara a consciência de um sobre o ato $^{340}$ e a inconsciência do outro ${ }^{341}$ se mostra na maneira pedagógica com a qual o sobrinho introduz o problema do interesse e o vê como permeando todo o tecido social:

EU — Então, há alguém que tenha a coragem de ter a vossa opinião? ELE - O que chamais de alguém? É o sentimento e a linguagem de toda a sociedade.

EU — Neste caso, entre vós, aqueles que não forem grandes velhacos só poderão ser grandes tontos.

ELE - Tontos? Aqueles? Pois eu vos juro que há um só e é justamente aquele que nos festeja para que o iludamos.

EU - Mas como se deixar iludir tão grosseiramente? Porque, afinal, a superioridade dos talentos da Dangeville e da Clairon é coisa decidida.

${ }^{338}$ O que Hegel observa bem como sendo algo típico da época: "Nessa tarefa negativa, a pura inteligência se realiza a si mesma, ao mesmo tempo, e produz seu objeto próprio - a essência absoluta incognoscível e o útil". HEGEL, 1999, p.37, itálicos do autor.

${ }^{339}$ HEGEL, 1999, p.57.

${ }^{340}$ Daí ser uma consciência dilacerada, se sabe entre um polo e outro e não consegue executar a síntese. Seu problema está em saber situar onde também ela é honrada.

${ }^{341}$ Por isso consciência honrada dado acreditar genuinamente na força vinculante dos pressupostos morais. 
ELE - Engolimos em grandes sorvos uma mentira que nos lisonjeia; bebemos gota a gota uma verdade que nos amargura. Além disso, assumo um ar tão compenetrado, tão verdadeiro...

EU - Entretanto, penso que de vez em quando deveis pecar contra os princípios da arte e que por descuido deixais escapar algumas dessas verdades amargas que ferem, pois, a despeito do papel miserável, abjeto, vil, abominável que fazeis, creio que no fundo tendes a alma delicada.

ELE - Eu? De jeito nenhum! O diabo que me carregue se eu souber o que sou no fundo. Em geral, tenho o espírito transparente como cristal e franco como o vime: nunca falso, por pouco que me interesse ser verdadeiro, nunca verdadeiro, por pouco que me interesse ser falso. Digo as coisas que me vêm. Se sensatas, tanto melhor. Se impertinentes, ninguém liga. Uso plenamente minha franqueza. Em toda a minha vida nunca pensei antes de falar, nem falando, nem depois de ter falado. E assim não ofendo ninguém. ${ }^{342}$

Com sua linguagem franca, mas que nada diz de transparente, a consciência dilacerada personificada pelo sobrinho apresenta a contraface da consciência honrada, contraface essa que, ao menos, é consciente de sua situação. Assim, o sobrinho, porque não acredita saber nada sobre si, porque acredita que essa falta de sabedoria expressa na linguagem franca é o que constitui toda a sociedade e a permeia, se sente absolutamente seguro em se comparar com o cristal e o vime, expressão que justo indica transparência e ausência de dissimulação. É o problema da performance social e de sua pertinência a ela ou, nos termos que viemos utilizando até aqui, é o problema da aderência real às coisas que se vincula. Como o Sobrinho se sabe não aderindo, não pode dizer ser nem verdadeiro, nem falso; aprendemos disso que o contrário de veraz não é o falso, mas aquele que oscila entre um e outro, ou seja, o indecidivel.

Não é exatamente, então, que o sobrinho fale as coisas que fala pelo fato de que não quer ser veraz ou porque quer ludibriar. Não estamos reeditando com Diderot e Hegel o problema do pseudos em Platão: antes, aqui se trata daquele que é capaz de dizer a verdade de maneira que essa mesma seja uma mentira porque ofundamento de seu discurso não está onde deveria. A elocução, nesse sentido, desloca o sentido da verdade e da sinceridade, porque com base nessas pode-se perfeitamente chegar ao polo oposto daquele que seria a veracidade, mas também se pode chegar ao veraz.

342 DIDEROT, 2006, pp.-93-94, negritos nossos. 
Bascular, nesse sentido, permite uma linguagem que é franca, mas que não transparece o sujeito que a utiliza. Ele se mantém oculto nas malhas de seu eu profundo, o que ele "verdadeiramente pensa" sempre oculto para seu interlocutor. Nas palavras de Hegel, se mantém na vaidade.

Ademais, nesse diálogo vê-se que tudo se passa como se cada polo exercesse a essencialização de seu lado e ambos estivessem errados pelo exato mesmo motivo, embora em direções opostas. À consciência dilacerada, no entanto, cabe o papel de apresentação da falsidade da certeza ou, se se preferir, da falsidade de tal essencialização, sendo como que pedagógica em relação à consciência honrada. É como se ao demonstrar a completa falta de força vinculante entre uma proposição moral e uma reação esperada, o sobrinho apresentasse a negatividade inerente também às forças supostamente vinculantes às quais se apega o filósofo. Assim, num trecho como "EU - É que sois preguiçoso, glutão, frouxo, e tendes uma alma enlameada / ELE Creio que eu próprio vo-lo disse" 343 vemos o completo descaso do sobrinho para com os julgamentos morais proferidos, como se isso não fosse assunto seu. Esse verdadeiro drible que a assunção de uma certa opacidade afirmativa efetuada pelo sobrinho - i.e., “concordo, porém não me vejo diretamente concernido - é justo o que faz vacilar a certeza do filósofo, uma vez que se vê diante da impossibilidade de dar curso aos seus pensamentos de maneira direta. Por ser uma consciência honrada, não consegue ir adiante porque parece perder em seu próprio jogo.

Um momento no qual isso acontece de maneira muito explícita é aquele logo anterior ao acima citado. Nele, o sobrinho está discursando sobre como a "plateia imbecil" não consegue reconhecer a dimensão performática necessária aos artistas, como se a plateia fosse incapaz de lidar com a noção de encenação porque é incapaz de perceber que também, em seu dia a dia, encena ${ }^{344}$. A incapacidade dessa plateia, por seu turno, vai ser enunciada e incorporada de maneira muito direta pelo filósofo que tem dificuldades de conferir um sentido específico ao linguajar dúbio de seu interlocutor, dificuldade essa oriunda de sua honra, ou seja, de sua necessidade de entender a correspondência entre verdade e ação. Assim, dada a sua incapacidade de

\footnotetext{
${ }^{343}$ DIDEROT, 2006, p.144.

${ }^{344}$ DIDEROT, 2006, p.92.
} 
reconhecer, no deslocamento promovido pelo movediço negativo da fala do sobrinho, um lugar seguro da verdade, o filósofo enunciará:

EU - Como podeis dizer tais coisas? É ironia ou verdade?

ELE - O mal é que esse diabo do sentimento fica todo para dentro, não escapa uma faísca para fora. Mas eu que vos falo, eu sei, eu sei bem que ela o tem [a atriz da qual falava]. Se não é exatamente isso, é qualquer coisa parecida. É preciso ver, quando nos dá na telha, como tratamos os criados, como as camareiras são sopapeadas, como damos pontapés nas sisas desde que nos faltem com o devido respeito. Escutai o que vos digo, é um diabrete, cheio de sentimento e de dignidade... Esta, agora, vos deixou completamente desnorteado, não?

EU - Confesso que não consigo distinguir até onde vão vossa boa-fé e vossa maldade. Sou um homem simples. Tende, pois, a bondade de não usar meias palavras. Falai francamente e deixai vossa arte para lá. ${ }^{345}$

Esse último trecho é o que nos permite compreender, então, a exata dificuldade presente na ironia: para alguém que busca correspondências precisas, a fala irônica ou cínica só pode aparecer como "meias palavras", como deslocamentos perdidos e impossíveis de situar ou como uma “intelecção de que o conteúdo não é assim”, ou seja, que "é algo puramente negativo" "346. Temos, com isso, dois momentos de uma consciência, ambas presas à mesma atitude raciocinante, sem jamais serem capazes de ir além dela. Na leitura de Hegel a peça nos apresenta, nesse sentido, a versão honrada e a versão dilacerada mostrando que, do choque entre elas, a mesma posição sobressai: para uma, perder todo o conteúdo é chocar-se com a negatividade e ter seus modos de expressão impossibilitados e, numa expressão coloquial, fica emperrada no negativo como barreira, posto não reconhece-lo como móbile; para a outra, se manter dentro do negativo é reduzir completamente toda verdade de um conteúdo às suas mediações, como se toda aposta num conteúdo de verdade já estivesse maculada por uma série de mediações a ele necessária e que, por isso, de maneira nenhuma pode ser uma aspiração

345 DIDEROT, 2006, pp.92-93, negritos e colchetes nossos.

${ }^{346}$ HEGEL, 1992, p.54. 
à verdade no sentido mais puro. Ela também emperra, por assim dizer, mas o faz por uma nostalgia de um momento no qual a verdade se fazia presente ${ }^{347}$.

Vê-se, aqui, o parentesco da estratégia cínica do personagem de Diderot com a estratégia fenomenológica hegeliana do primeiro capítulo da obra por nós analisada: nos dois casos, o que ambos percebem é que para que se possam realizar as expectativas que os atos de elocução trazem consigo, é preciso uma série de mediações que não podem ser coetâneas aos pressupostos nos quais elas se suportam. A tentativa de realizar é o que inverte o que se tenta realizar, uma vez que trazem à tona a necessidade da mediação como elemento fundamental. Mas o parentesco, como esperado, termina aí. Como vimos, o capítulo um da Fenomenologia propulsiona a consciência a buscar uma resposta e, daí, surge o capítulo dois com uma nova posição da consciência que será novamente refutada e assim sucessivamente. Aqui, ao contrário, o assunto se aprofunda no quanto, tendo invertido os pressupostos iniciais por sua realização, é possível haver a performance sem o enraizamento desta num solo outro que não o das mediações. As consciências em nenhum momento conseguem por si mesmas resolver o problema, porque estão dentro da atitude raciocinante, o que significa que ainda buscam um conteúdo exterior à própria coisa, algo que a própria razão não tenha tocado e chamado de sua. Essa atitude pode assumir a recusa dos desejos humanos particulares, momento no qual a marca do desejo como negativo impede que a consciência honrada se enxergue desejante; ou pode assumir a forma de uma consciência que somente percebe os desejos humanos e usa de sua argumentação para reencontrá-lo constantemente, a coisa exterior para sempre perdida servindo de horizonte nostálgico de recusa.

Para esse último ponto, ressaltamos como o sobrinho cita a sua própria experiência como professor, mais especificamente a maneira como pôde ocupar de maneira irônica o lugar de formador de alguma jovem performando como se realizasse algo, mas sem nunca de fato realizar pedagogia alguma. Para tanto, descreve minuciosamente tudo o que fazia para se assimilar a um professor legítimo, performando o que dele era esperado sem ter um fundamento por sob os pés que

\footnotetext{
${ }^{347}$ Foge ao nosso escopo uma análise extensiva da peça, posto que nós nos restringimos aqui à leitura de Hegel da obra. Para uma hipótese sobre essa nostalgia se mostrar no momento em que o sobrinho fala de música CF SAFATLE, 2007.
} 
garantisse a verdade de suas palavras. Como a performance é similar e corresponde às expectativas de comportamento que se tem em relação ao professor que ele afirma ser, ela convence aos interlocutores ${ }^{348}$; como o desenraizamento da performance em relação ao conhecimento é uma das marcas da modernidade ${ }^{349}$, sua apresentação faz sentido dentro do contexto do diálogo satírico como uma possibilidade real, embora risível de comportamento. A jocosidade comparece aqui como um instrumento da destruição da pretensão à seriedade própria ao Esclarecimento, como se Diderot descortinasse o grau de performance do movimento e risse dele e de suas pretensões à neutralidade.

O escárnio se faz, aí, em dois níveis performáticos: primeiro no nível das ações contadas pelo sobrinho, posto que explicita que sua performance não precisa ser contrária à ou diferente da performance da verdade, pois ela se mostra como tendo seus pressupostos compartilhados e assentados nos mesmos valores que a ação daqueles que agem de maneira legítima; e na própria elocução, a partir da sátira da narrativa sobre o ato feito, o efeito de escárnio vindo justo da comparação entre o puramente performático e o real como seres igualmente falsos naquilo que pretendem fazer.

Esse último é o que aponta para a redução às mediações da qual falávamos: quando mostra que tudo o que o humano faz, inclusive a apresentação da verdade, depende de um grau performático, o que ocorre é a redução do próprio conteúdo à forma o que, sub-repticiamente, introduz a questão estética da forma e do conteúdo e de sua copertinencia. Hegel é especialmente preocupado com esse problema estético

348 Perguntado como dava aulas, o sobrinho responde: "Como todos fazem. Chegava, jogavame numa cadeira. "Como o tempo está ruim! Como é cansativo andar a pé!" Tagarelava sobre algumas novidades: "A Srta. Lemierre devia executar o papel de vestal na nova ópera, mas está grávida pela segunda vez e não se sabe quem irá dublá-la. A Srta. Arnauld acaba de abandonar seu condezinho; dizse que está negociando com Bertin. O condezinho, porém, encontrou a porcelana do Sr. de Montamy. No último concerto dos amadores havia uma italiana que cantou como um anjo. Esse Préville tem um corpo raro, é preciso vê-lo no Mercúrio Galante; o trecho do enigma é impagável. A pobre Dusmenil não sabe mais o que faz. Vamos, senhorita, pegai vosso livro". Enquanto a senhorita, sem a menor pressa, procura o livro que deixou extraviar, chama-se uma criada, esbraveja-se. Continuo: "— A Clairon é verdadeiramente incompreensível. Fala-se de um casamento muito ridículo: o da senhorita... como se chama mesmo? Uma criaturinha que ele mantinha, em quem fez duas ou três crianças e que havia sido mantida por muitos outros. - Vamos, Rameau, não é possível dizeis um disparate. — Não digo disparate algum. Diz-se mesmo que a coisa já está consumada. Corre o boato que Voltaire morreu; melhor. - E por que melhor? - É que deve estar preparando uma boa galhofa." (DIDEROT, 2006, 71-73). O trecho é ainda mais longo e contém uma viravolta no comportamento do Sobrinho, mas ela serve apenas para melhor corresponder às expectativas que se tem em relação a ele e ao seu papel.

${ }^{349}$ SAFATLE, 2007. 
da imbricação entre forma da apresentação e conteúdo apresentado. Não à toa, será com virulência e humor misturados que Hegel atacará a preferência romântica pela poesia em detrimento do conceito:

Não é nada agradável ver a ignorância e a grosseria, sem forma nem gosto - incapazes de fixar o pensamento numa proposição abstrata sequer, e menos ainda no conjunto articulado de várias proposições -, garantindo que são, ora a expressão da liberdade e da tolerância do pensar, ora a genialidade. Genialidade que, como hoje grassa na filosofia, antes grassava igualmente na poesia, como é notório. Porém, quando tinha sentido o produzir de tal genialidade em lugar de poesia, o que engendrava era uma prosa trivial; ou, se saía para além da prosa, discursos desvairados. Assim, hoje, um filosofar natural que se julga bom demais para o conceito, e devido à falta de conceito se tem em conta de um pensar intuitivo e poético, lança no mercado combinações caprichosas de uma força de imaginação somente desorganizada por meio do pensamento - imagens que não são carne nem peixe; que nem são poesia nem filosofia (Gebilde, die weder Fisch noch Fleisch, weder Poesie noch Philosophie sind). ${ }^{350}$

A tradução, aqui, apesar de denotativamente correta, perde tanto a possibilidade de dar a entender o que Hegel quer expressar do ponto de vista da sonoridade (Fisch/Fleisch), quanto do ponto de vista do jogo de palavras corriqueiro do idioma, algo que seria equivalente a uma versão ainda mais intensa de "nem barro, nem tijolo", do português. Quando condensadas as duas faces da expressão utilizada, o que vemos é Hegel apontando como a impossibilidade de decisão por uma forma propriamente filosófica - forma essa que seria também a escolha por um tipo específico de conteúdo - já implica no desconhecimento e na falha daqueles que escrevem em poesia buscando fazer filosofia. Não existe, desde o ponto de vista hegeliano, filosofia poética ou poética filosófica: o efeito estético da beleza das sentenças ou da construção de imagens poética (e Hegel tem também as suas sentenças belas e imagéticas) é secundário, não primordial à filosofia, posto que ela não se expressa primordialmente de maneira poética, sendo antes o desdobramento lógico do conceito. Para um tal desdobramento, a forma que lhe cabe é um sistema que comporte e se componha do desdobramento do mesmo jeito que um círculo comporta e se compõe do traçado que o faz. Para Hegel, a única beleza do conceito é a beleza da necessidade, um pouco como se os nexos causais bem estabelecidos fossem a única possibilidade de se pensar uma tal coisa.

${ }^{350}$ HEGEL, 1992, p.59. 
Não espanta que o cínico moderno e o poeta romântico, para Hegel, sejam irmanados. Se retornarmos à leitura que faz do texto de Diderot, vemos bem que a falsidade da filosofia poética e a falsidade das sentenças e poesias românticas, são ambas fruto do seu choque com o negativo. No caso específico da ótica do Sobrinho, um tal negativo comparece ao menos duas vezes: primeiro, como o negativo presente na fala de seu interlocutor ao ser cínico (ainda que insciente disso) quanto às expectativas de reconhecimento que animam de fato a busca por uma educação artístico-intelectual; em segundo, como o negativo da pura performance sem conteúdo que faz e narra ele mesmo como professor. Nos dois casos, é o negativo que simplesmente toma a ironia como forma unicamente porque o conceito de identidade que busca criticar domina a própria crítica. Assim, apesar das funções pretensamente críticas de cínicos e românticos, eles apenas se mantêm confirmando a mesmíssima identidade que buscam reduzir ao negativo.

Uma vez que o Eu passa a ser o fundamento do conhecimento, se torna impossível saber se uma performance contém algum grau de verdade ou não salvo quando se é testado num embate dialógico (e, muitas vezes, nem mesmo assim) ${ }^{351}$. Pior do que impossível, grosso modo, passa a se tornar irrelevante para o público que se quer atingir, uma vez que o importante passa a ser a forma em detrimento do conteúdo. No caso específico da peça, isso se dá porque o sobrinho é um leitor da realidade social na qual está imerso melhor do que o filósofo; este se mantém ainda muito inconsciente do seu lugar social e da dimensão social dos seus atos. O cínico, não. Plenamente cônscio da importância do convencimento e das emoções num processo educativo e igualmente capaz de observar a da falta de força que possui a verdade por si só - e a comparação com sabores é bastante reveladora do peso que o sobrinho dá as emoções do seu público no processo -, o sobrinho sabe perfeitamente bem como emular aquele que é suposto saber algo a partir das expectativas dos seus interlocutores. Apesar de sua consciência ser dilacerada (talvez por isso mesmo), é capaz de ajustar seus trejeitos,

351 Não à toa há todo um trecho do Parerga de Schopenhauer que ensina a como vencer um debate sem precisar ter razão. A retórica, na modernidade, ganha ainda mais peso, uma vez que tudo passa a se resolver nas maneiras pelas quais a linguagem é mobilizada. Do Direito à Psicanálise, passando por Filosofia, História e, em algum grau, até mesmo as ciências duras, tudo precisa ser encorpado numa linguagem convincente, a despeito do seu valor de verdade. O contemporâneo debate sobre fake News não é outra coisa do que uma superinflação disso. 
seus modos de agir e etc. para corresponder às expectativas sem nunca ser, de fato, quem ele emula ser.

É essa mobilidade do Eu em sua performance social que Diderot está observando e que interessa a Hegel e é a isso que ele está chamando de vaidade: como o próprio Eu não se permite imergir no conteúdo e antes reduz este à pura forma, o mesmo Eu como que paira sobre ele o reduz ao negativo precisamente porque ele já o vê a partir de sua negatividade inerente. Daí que ele, a partir da "afirmação do vazio, assegura estar sempre mais avançado que uma intelecção rica-de-conteúdo" ${ }^{\text {352. As }}$ destruições de conteúdo são, assim, a uma certa forma de astúcia que, apesar de progredirem nas discussões da relação entre forma e conteúdo e na introjeção do negativo nos elementos da discussão, ainda falham em fazer disso um móbile precisamente porque, conforme sabemos, repetem com nostalgia o antigo conceito de identidade.

Isso é particularmente visível no fato de a consciência dilacerada, que é o sobrinho, não necessariamente ver em seus predicados uma definição sua que possua capacidade de servir de crítica moral a si. Não é à toa que Hegel insiste que é na separação entre sujeito e predicado que jaz o motivo principal da atitude raciocinante poder agir como o faz. Afinal, a separação executada no juízo entre um e outro é justo o que faz com que o sujeito não precisa se reconhecer nos predicados "preguiçoso, glutão, frouxo, e tendes uma alma enlameada" a ele atribuídos, para ficar apenas num dos exemplos da peça. Por isso Hegel pode dizer que

“o próprio pensar raciocinante é o $\mathrm{Si}(\mathrm{Selbst})$ ao qual o conteúdo retorna; porém, no seu conhecer positivo, o Si é um sujeito (subjekt) representado, com o qual o conteúdo se relaciona como acidente e predicado. O sujeito constitui a base a qual o predicado está preso, e sobre a qual o movimento vai e vem." 353

Uma vez que o predicado é meramente secundário e não "a base”, o sujeito não se vê vinculado de maneira indissociável a ele, tampouco se vê contemplado nele como se uma definição fundamental dele fosse fornecida. Daí o sobrinho poder se descrever de um jeito bastante vil sem nunca ter sua subjetividade realmente visada pela descrição

\footnotetext{
${ }^{352}$ HEGEL, 1992, p.54.

${ }^{353}$ HEGEL, 1992, p.55.
} 
dada, uma vez que ela é ontologicamente algo de distinto do predicado. A fraqueza de coação moral que a acusação do filósofo possui advém justo da mobilidade do negativo pressentida pelo sobrinho em sua consciência dilacerada. Ele pressente ser qualquer coisa que não aquele visado, um negativo que não se reduz àquelas características. Embora possua sempre consciência de que pode ser correspondente aos predicados, pode sempre experimentar a atribuição irônica da verdade como uma solução a esse problema. Declarar-se como um sujeito vil não precisa, necessariamente, ter unicamente a função de identifica-lo com a vileza da qual fala: pode servir ironicamente como um simples dispositivo de autorreflexão, o que, por si só, “já o colocaria para além de todo contexto determinado" 354 .

No entanto, precisamente porque nega seus contextos determinados e deles se utiliza para reduzir uns aos outros, advém um sentimento de dilaceração que se mostra no fato de que ele se diz incapaz de conceber o que é no fundo: como nenhum contexto o reduz ou o engloba, dado que sempre pode como que saltar por sobre eles pela reflexão sobre si - reflexão que, lembremos, por princípio introduz o negativo -, o indivíduo se vê dessituado ou atopoi, sem lugar. Isso é próprio daquele que reflete ou busca refletir sobre si e se capturar de maneira essencial, como se buscasse seu próprio fundamento. A atopia advém do fato de se perceber sujeito, ou seja, uma coisa para além das determinações fixas, uma coisa pensante que precisa complementar com “mas, por quanto tempo?" quando diz que pensa, logo existe ${ }^{355}$.

Ademais, a própria ideia de que exista um fundo de verdade que deveria ser passível de ser descoberto já é índice e sintoma de uma aderência a pressupostos que, no entanto, são negados a cada vez. Se a posição é cínica como o é a de Diógenes, será dele que Hegel dirá que enquanto está "no seu tonel, está condicionado por esse mundo" 356 , ou seja, toda a atividade de contraposição de Diógenes (e do sobrinho) é justo a impossibilidade dele de se afastar de um "mundo de inversão", que é

${ }^{354}$ SAFATLE, 2007, p.38.

${ }^{355}$ Entende-se, então, os elogios a Sócrates e à sua atopia, algo recorrente no romantismo: posto que os românticos estão compreendendo Sócrates como um sujeito que sobre si refletia, vê-se o parentesco entre autores que se veem dessituados porque refletem e desse destino se aproveitam e um que se vê sem lugar na sua cidade porque tem por destino a reflexão. Dito de outra maneira: nos dois casos são a reflexão e a ironia, o casamento perfeito, que retiram o lugar fixo do sujeito e sua possibilidade de redução contextual.

${ }^{356}$ HEGEL, 2000. 
precisamente aquele que apresenta ao filósofo. Estando condicionada por esse mundo, a consciência dilacerada só pode constantemente se mostrar em seu eterno embate com ele, posto que em nada consegue alterá-lo. O humor com o qual se manifesta não nos mostra outra coisa que a sua impossibilidade de apreender o substancial, justo porque se foca exclusivamente em julgá-lo $o^{357}$, ou seja, cindir a coisa de que fala a cada vez que dela se ocupa, no momento mesmo em que busca a unidade.

Seu humor é, então, o coroamento de um processo específico, processo esse que o põe na contramão do pensamento especulativo ao mesmo tempo em que dele o aproxima. Como a Fenomenologia visa ensinar o ponto de vista da apreensão da realidade e não o de sua modificação, o uso de Diderot e dos românticos como contraste funciona particularmente bem, especialmente se pensamos que em uma das obras de aula (Filosofia do Direito), Hegel definiu sua dialética da seguinte maneira:

Tal dialética não é, portanto, a ação extrínseca de um intelecto subjetivo, mas sim a alma própria de um conteúdo de pensamento de onde organicamente crescem os ramos e os frutos. Enquanto objetivo, o pensamento apenas assiste ao desenvolvimento da ideia como atividade própria da sua razão e nenhum complemento lhe acrescenta da sua parte ${ }^{358}$

Disso fica claro que o contraste que Hegel vê entre si e seus colegas românticos não poderia ser maior. Em um temos um Eu que constantemente não apenas introduz definições nas ideias como, precisamente porque se sabe as introduzindo, brinca com elas e não as leva a sério de maneira fluida e fugidia, o humor sendo a marca maior disso. Noutro, temos o pensamento que busca aprender aquilo sobre o que se debruça nas suas própria determinidades, sem jamais adicionar nada que não a própria capacidade de observação. Isso nos adiciona uma camada de explicação no porquê de Hegel chamar de atitude raciocinante ou argumentação o procedimento que descreve e atribui aos românticos: é realmente uma densidade argumentativa muito grande que perpassa tanto o conteúdo quanto a motivação de sua argumentação

Agora como outrora, será caso de uma tal atitude ficar bastante marcada na maneira pela qual a linguagem é compreendida dentro desse contexto. Se no capítulo

\footnotetext{
${ }^{357}$ ARANTES, 1996, p.35.

${ }^{358}$ HEGEL, 2010, p. 73.
} 
quatro, cujo motor era a consciência-de-si, a linguagem foi compreendida como externalização e perda de si, aqui ela será compreendida como o que há de mais perfeito em termos de expressão do mundo da cultura ${ }^{359}$. Antes disso, no entanto, a relação com o eu e sua enunciação é estabelecida do seguinte modo:

Mas a linguagem contém o $\mathrm{Eu}$ em sua pureza; só expressa o $\mathrm{Eu}, \mathrm{o}$ Eu mesmo. Esse ser-aí do Eu é, como ser-aí, uma objetividade que contém a verdadeira natureza dele. O Eu é este Eu, mas é igualmente o Eu universal. Seu aparecer também é imediatamente a extrusão e o desvanecer deste Eu, e por isso seu permanecer em sua universalidade. O Eu que se expressa é escutado: é um contágio, no qual passou imediatamente à unidade com aqueles para os quais 'está-aí', e é consciência-de-si universal. Em ser escutado, nisso expira imediatamente seu ser-aí mesmo: esse seu ser-outro retornou a si, e justamente isso é seu ser-aí como [um] agora consciente-desi: já que está aí, não [mais] estar-aí, - e através desse desvanecer, estar aí. Assim, esse desvanecer é ele mesmo, imediatamente, seu permanecer; é seu próprio saber de si, e seu saber de si como de alguém que passou para outro $\mathrm{Si}$, que foi escutado e é universal. ${ }^{360}$

Aquilo que aparecia antes como reduplicação entre o sujeito sabedor (Wesende) e o sujeito do qual se predica aqui aparece cindido entre enunciação e enunciado, entre seu caráter universal e singular, entre a referência precisa e a pertinência a uma universalidade genérica. O que vemos, aqui, é como esse Eu pode ser consciência dilacerada: dado que é de sua natureza ser permanência porque passagem ao universal, é de sua natureza jamais ser correspondente aos predicados a ele atribuídos. A enunciação não é mais uma externalização e uma perda de si como outrora porque aqui já não é apenas um $\mathrm{Eu}$ que se desvanece e tem por pressuposto de verdade sua autoconsciência e a capacidade de determinar por si mesmo as definiçõos de seus enunciados. Tampouco é o momento ainda anterior, do capítulo um, no qual a consciência recorria ao Eu como refúgio último contra a demonstração de sua falta de saber sobre o objeto. Nada disso se passa aqui. Aqui, ao dizer "eu", a consciência já sabe da existência de uma plateia que o escuta e do seu momento fugidio de expiração como fundamento mesmo da sua emissão linguística. É exatamente porque tem disso grande noção que pode o sobrinho o tempo todo ironizar sua conduta e transformar sua reflexão em destruição de contextos. Desde que faça comparecer sua dimensão

\footnotetext{
${ }^{359}$ HEGEL, 2000, p.55.

${ }^{360}$ HEGEL, 2000, p.49.
} 
substancial sempre alhures, sempre naquilo que foi dito de maneira sutilmente deslocada, se conserva sempre numa dilaceração, numa impossibilidade de ser apreendido de maneira precisa.

Isso gera a dilaceração precisamente porque rompe com a passagem do eu enunciado ao universal ou, se se preferir, porque curto circuita as possibilidades de “contágio" - para manter a expressão hegeliana - recusando, através da antecipação, o retorno a si que deveria advir do outro. É como se, em algum grau, o sujeito se antecipasse e se criticasse para que se tornasse impossível para o outro fazê-lo de maneira mais direta.

Tudo se passa como se ocorresse uma transformação, no romantismo e no cinismo, do topos da clemência retórica numa dimensão existencial: antes mesmo do sujeito enunciar quaisquer coisas e já antecipando como será compreendido, o indivíduo anuncia tudo aquilo que dele será predicado. Uma vez que percebe aquilo como um predicado que o outro o conferiria e, portanto, como algo de duplamente outro em relação a si (predicado não sendo fundamental ao sujeito, antecipação do outro não permitindo a localização no contexto), toda possibilidade de o indivíduo estar situado se dissolve como num truque de mágica.

É importante salientar, ainda outra vez, como esse comportamento, tanto quanto a dialética hegeliana, são uma resposta ao desenraizamento moderno, aquele mesmo que Hegel identificou como sendo capaz de trazer um novo mundo. Dito de outra maneira, o cinismo que aqui ressurge só o faz na medida em que tudo que perduraria se vê às beiras de sua fluidificação, a identidade não sendo mais uma categoria passível de ser pensada desde o ponto de vista da sua manutenção substancial. Por se manter nostálgico da identidade, o romantismo será um passo anterior ao pensamento especulativo e, por isso, Hegel fará questão de dar à ele um lugar muito preciso:

De fato, o pensar não especulativo tem também seu direito, que é válido, mas não é levado em conta no modo da proposição especulativa. A suprassunção da forma da proposição não pode ocorrer só de maneira imediata, nem mediante o puro conteúdo da proposição. No entanto, esse movimento oposto necessita ter expressão: não deve ser apenas aquela freagem interior, mas esse retornar do conceito a si tem de ser apresentado. ${ }^{361}$

${ }^{361}$ HEGEL, 1992, p.57. 
Essa é outra forma de dizer que já na forma proposicional ou, se se preferir, na sua conservação, se torna visível a maneira pela qual o pensamento especulativo se diferencia do raciocinante. Este último ainda busca predicar sujeitos, ainda não compreendeu a dimensão de desenvolvimento que deveria estar implicada em cada ato proposicional e, por isso, ainda não é capaz de propriamente pensar a cultura como o cultivo do espírito, apenas como aquilo a que se contrapõe.

Apesar das diferenças (existe um projeto no romantismo apesar de sua ironia, afinal), uma tal contraposição também é sentida no cinismo moderno e na pena de Diderot. Assim, é possível afirmar que quando criticando a sociedade, a ironia ou o cinismo "não fala contra a verdade, pois não fala em nome dela; não é moral nem imoral, pois não opera sobre o pressuposto dessa distinção; não é hipócrita: não esconde seu ser verdadeiro, pois é nada "no fundo", não tem nenhuma essência" ${ }^{362}$. Sobra apenas, então, frente à ironia ou ao cinismo, a desintegração da verdade, posto que frente até mesmo à hipótese de banimento à loucura ou à desrazão ele já está preparado $^{363}$.

Não falar em nome de nenhuma verdade e ainda assim inocular uma semente de falso na verdade é uma forma precisa de mostrar que razão e loucura operam como antíteses irreconciliáveis e que a primeira, quando reconhece em si um traço da última, se vê impossibilitada de progredir. Ainda seguindo a Hegel, seria por isso que o humor dos diálogos de Diderot ou a ênfase dos românticos no chiste não seriam mais do que estilo, o jogo debochado com a sonoridade de Fisch e Fleisch ao falar da indecidibilidade de estilos demonstrando inclusive formalmente o proselitismo de tal operação.

Isso terá consequências bastante profundas também em relação a presença ou não de humor nos textos hegelianos. Seu caráter marcadamente árido e sisudo é demarcado tanto por Koyré quanto por Arantes. O primeiro, para contrapor aos textos de juventude, nos quais a emoção mais livremente pululava ${ }^{364}$; o segundo, para demarcar a algo particular a o autor: "Hegel erige o momento inexpressivo da seriedade

\footnotetext{
362 FILHO, 2004, p.57.

${ }^{363}$ Ibid, idem.

${ }^{364}$ KOYRÉ, 2011, p.149-150.
} 
em princípio de estilização"365. Quer isso dizer que os chistes, os coloridos da linguagem, as metáforas e imagens muito vívidas que marcam os fragmentos e obras românticos são relegadas a apenas estilo, como se fossem apenas bibelôs frente ao necessário trabalho do conceito. Percebe-se aí que a estilização hegeliana opera por sua contrapresença, como se marcasse que quando menos presente o indivíduo se fizesse em seu texto, mais a verdade estaria, por seu turno, presente e mais o sujeito também assim estaria, já que o objetivo da educação é justo uma "auto universalização" 366 .

Como pressupõe a verdade que critica, a consciência dilacerada jamais consegue dar um passo adiante, jamais consegue abandonar sua nostalgia e jamais consegue, no fim, propor uma reconciliação, dado desconhece que a contraface que descobre como inerente à verdade da consciência honrada não a anula, conquanto se saiba como pensar o que é verdadeiro. Essa, outra forma de dizer que quando Hegel intenta fazer o movimento da substância a sujeito, do efetivo ao lógico, da separação à junção, ele o faz alterando a totalidade do processo ao englobá-lo.

\subsection{A caminho do especulativo}

Conforme já afirmamos algumas vezes e como tem sido a tônica até aqui, podemos dizer que a junção de todos os aspectos da vida na reflexão hegeliana é uma recusa da divisão dessa mesma existência em aspectos, como se fosse possível uma reflexão moral sem uma epistemologia e uma estética que a acompanhassem. Outra forma de dizer isso, é falar como Bourgeois e dizer que Hegel moraliza a dialética antiga ao mesmo tempo em que dialetiza a moral moderna ${ }^{367}$, ressaltando estes aspectos pensados como ausentes em seus respectivos tempos.

Resta, então, a pergunta relativa à pertinência disso num livro que se detém de maneira tão direta sobre a formação. Ora, o problema todo se encontra precisamente no aspecto formativo ou, mais precisamente ainda, a educação em seu caráter e dever de formação do indivíduo para a liberdade. Dado que é a educação quem estabelece os

\footnotetext{
365 ARANTES, 1996, p.33.

${ }^{366}$ BOURGEOIS, 2004.

${ }^{367}$ BOURGEOIS, 2004.
} 
critérios de verdade a partir dos quais os indivíduos irão conceber o mundo em sua objetividade e subjetividade ${ }^{368}$, será então nela que deverá o pensamento hegeliano incidir. Se partirmos da dualidade necessária àquilo que Hegel chama de terra pátria da verdade, a saber, o Eu, e entendermos como Hegel está pensando a maneira pela qual seus pares pensaram essa figura, compreenderemos o que se quer dizer aqui. Essa é, também, ainda outra forma de entender o par consciência dilacerada/honrada.

No caso do romantismo e da consciência dilacerada um excesso de sujeito e subjetividade se faz ver e as interações cínicas entre ela e o mundo ou seu meio social; como vimos, ressalta-se, aí, a não pertinência do Eu àquele contexto, de modo que o fato de que o Eu diga respeito àquela singularidade específica que o emite é o que mais fica evidente. Poderíamos dizer, então, que é uma posição do Eu versus o mundo, na qual o Eu triunfa precisamente por se manter inalterado frente a seu adversário e poder toma-lo por objeto que anula.

Isso curiosamente nos leva, dialeticamente, à consciência honrada, posto que a ênfase na anulação do objeto pode ser lida como pressupondo, em algum grau, uma certa subserviência a ele. A observação que citamos acima, sobre Diógenes em seu tonel, bem o confirma. Nesse sentido, a consciência honrada se mantém presa à objetividade, reconhecendo apenas o caráter universal da enunciação da partícula Eu e, ao se focar nela, elide completamente a manipulação que faz do conteúdo porque elide a sua própria participação na construção e escolha desses valores. Isso é análogo ao que faz Kant ao construir, na Crítica da Razão Prática, um edifício segundo o qual se torna impossível a percepção de um sujeito que o constrói, especialmente porque ele trata sua máxima como um imperativo da razão, algo impessoal e universal, portanto.

Em suma, ambos são faces da mesma moeda dialética (como o foram Antígona e Creonte outrora) porque suas realizações pressupõem, cada qual, a alteridade que visam elidir em seu discurso. A filosofia hegeliana, especialmente aquela contida na Fenomenologia, por estar focada no caráter formativo da educação, vê que é já daí que surgem os problemas relativos às más compreensões da realidade. Assim, ao apresentar suas críticas e ao identificar neles uma atiitude raciocinante Hegel "propõe-se, portanto, a instituição de uma filosofia tal que ela seja, como filosofia, isto é, como

${ }^{368}$ Como a carta de Hegel a Niethammer, citada nessa tese, explicita. 
saber total, ensinável - isto contra o romantismo -, e ensinável como saber total - isto contra a renúncia crítica"369. Forma de dizer que um saber total, ensinável e que uma a subjetividade e a objetividade criando "uma subjetividade objetiva ou uma objetividade subjetiva"370 é o objetivo ao ensinar a filosofia especulativa.

Isso não vai sem um longo percurso de reconhecimento do caráter formativo dos estudos até ali feitos, posto que o reconhecimento da formação é tão mais difícil quanto mais ela forma o que equivale a lembrar o que constantemente diz Hegel: o bem conhecido nem por isso é reconhecido. Existe, então, uma relação de copertencimento entre aquilo que existe de sensível e natural e aquilo que existe de espiritual, de modo que a ligação existente entre pensar e ser não pode ser, de maneira nenhuma, gratuita e fortuita, precisando antes possuir uma necessidade.

$\mathrm{O}$ fato de o caráter de formação não comparecer na atitude raciocinante demonstra apenas que esta, se faz comparecer um momento negativo, o faz apenas para se manter na abstração figura maior criticada até aqui. E isso por um motivo específico, qual seja, o fato de que o próprio negativo é tomado como estanque ou como oposição abstrata ao positivo, significando então que não existem quaisquer possibilidades de pensar o desenvolvimento ou a formação que, nesse caso específico, são termos sinônimos. Assim, a ausência de automovimento ou de um autocolocar-se é o que torna a negatividade que aí circula incapaz de ser identificada à identidade como parte.

Nessa sua última camada, a crítica nos fornece, então, a possibilidade de mostrar a diferenciação bastante específica que o ancora o conceito de formação hegeliano, a saber, o conceito de desenvolvimento. Se, ao começo, Hegel já situou a verdade como o Todo e este último como aquilo que se implementa, ou seja, que se desenvolve, será caso, então, que algo apenas será verdade, desde o ponto de vista especulativo, se a totalidade se desenvolver em um elemento ou meio que não é ela "na medida em que promove um momento abstrato dela" 371 . Quer isso dizer, então, que a mesmíssima abstração criticada por Hegel, é reabsorvida pelo Todo como momento, sendo sua totalidade em progresso a medida pela qual a verdade também perpassa essa parte que, por ser verdade, ele também é.

\footnotetext{
369 BOURGEOIS, 2004, p.336.

370 Ibid, p.335.

${ }^{371}$ BOURGEOIS, 2004, p.306.
} 
Nesse sentido, é apenas englobando dialeticamente tanto a consciência honrada quanto a consciência dilacerada como momentos justapostos que se diferenciam, mas que possuem, ao mesmo tempo, identidade, que ambos esses momentos podem ser reaproveitados como propulsores do movimento do Espírito. Se é bem verdade que a crítica de Hegel incide sobre uma figura central, a ironia, é igualmente verdade que ela apenas o faz na medida em que esta figura é a contraface negativa do entendimento que abstrai, vez que tanto ela como ele congelam o movimento, cada qual a seu modo.

Nos dois casos, assim, tudo se passa como se não houvesse a possibilidade do outro polo constituir este polo, como se um jogo de exclusões estivesse de antemão posto em cena e operando os movimentos a (não) serem feitos. $\mathrm{O}$ congelamento e o ignorar do caráter formativo é, ao mesmo tempo, o esquecimento da centralidade do desenvolvimento, figura complementar que permite a justificação lógica do começo do processo no seu fim. Dito de outro modo, a formação é o termo da Fenomenologia que corresponde ao desenvolvimento que acontece na Ciência da Lógica e, por isso, ao final de ambas, o começo que fenomenologicamente surge como pressuposto ressurge, no fim, como justificado e ao fim unido.

Agora que chegamos até aqui, no momento último antes do especulativo, nos resta apenas a questão: o que propõe Hegel?

\subsection{O especulativo e as proposições especulativas}

A primeira coisa que causa uma certa dificuldade na localização do que é específico de um pensamento especulativo a partir do qual Hegel opera é a maneira pela qual o autor, de alguma forma, parece simplesmente analisar proposições e fazer a demonstração lógica daquilo que chama de especulativo, sem nunca o definir de maneira direta. Nesse sentido, então, uma nomeação direta de um certo tipo de proposição chamada especulativa em muito facilita para o leitor. É curioso que uma tal nomeação, a de uma proposição especulativa, somente apareça no prefácio de nossa obra e não torne a aparecer em lugar nenhum do livro. Isso faz desse um dos poucos momentos na obra aqui analisada no qual Hegel parece preocupado em fornecer uma 
definição, abstrata que seja, do que são as proposições com as quais vai operar. Mais do que isso: Hegel contrapõe seu modo de operar às proposições raciocinantes, aquelas mesmas que são oriundas de certa Räsonieren que estivemos analisando até aqui.

De início, uma tal distinção entre as proposições não parece ser tão grande assim, pois o especulativo parece manter uma estrutura proposicional similar:

Para esclarecer com exemplos o que vai dito, na proposição "Deus é $o$ ser" (Gott ist das Sein) o predicado é o ser: tem uma significação substancial na qual o sujeito se dissolve. Aqui "ser" não deve ser predicado, mas a essência; por isso parece que, mediante a posição da proposição, Deus deixa de ser o que é - a saber, sujeito fixo.

Para além da presença do artigo (“Deus é o ser”), pouco parece ter mudado na proposição especulativa em relação as proposições clássicas, divididas em sujeito e predicado. Poder-se-ia arguir que "ser", em algum grau é o predicado de Deus e, apesar da dificuldade que isso poderia apresentar para a reflexão filosófica, a divisão lógicolinguística se manteria a salvo, i.e. Deus é sujeito, ser é predicado. Só que isso é ainda notar muito pouco do que está acontecendo aqui. Ao substantivar e dizer que um é o outro, Hegel está mantendo a especificidade de Deus e do ser ao mesmo tempo em que diz que o primeiro é o segundo. Nesse sentido, então, ambos possuem identidade, mas são não identitários ou, na formula hegeliana, presentificam a identidade entre a identidade e a não identidade. Se não fizermos isso e se buscarmos, ao contrário, manter a estrutura proposicional clássica, ficaremos perdidos, sem entender bem como duas universalidades podem se equacionar ou, mesmo, como ser pode ser predicado de qualquer coisa, dado que, ao menos desde Kant, ser não é predicado, mas condição de possibilidade de toda predicação.

Não é de outro jeito que procede Hegel ao diagnosticar que um proceder nesse caminho sem saber o que é o especulativo leva na seguinte direção:

em vez de progredir na passagem do sujeito ao predicado, se sente, com a perda do sujeito, antes freado e relançado ao pensamento do sujeito, pois esse lhe faz falta. Ou seja: o próprio predicado sendo expresso como um sujeito, como o ser, como a essência que esgota a natureza do sujeito, o pensar encontra também o sujeito imediatamente no predicado. Então, o pensar está ainda nas profundezas do conteúdo, ou, ao menos, tem presente a exigência de 
nele se aprofundar; em lugar de manter a livre posição do raciocinar que no predicado vai para si mesmo. ${ }^{372}$

Como Hegel está como que tentando ensinar à consciência como pensar especulativamente, ele precisa colocar esse problema de um modo que ela se refreie frente à repetição constante de sua tendência à abstração. Nesse sentido, a definição não pode ser estanque, mas móvel. Assim, a consciência se vê presa ao conteúdo e à forma da proposição e, porque tenta decodificar o que ela significa a partir dos seus pressupostos, chega apenas a pensar que Deus e o Ser não podem ser absolutamente identitários, pois se o fossem a proposição seria uma tautologia vazia e que nada diria. Assumindo que não é caso, passa a compreender que é como se a proposição estivesse versando sobre Deus e sobre o ser como se um sujeito fosse...predicado de um sujeito, o que é bastante sui generis.

A chave para o mistério, Hegel a dá logo depois, quando diz que "como proposição, o especulativo é somente a freagem interior, o retomo não aí-essente da essência a si mesma" ${ }^{373}$, ou seja, como proposição ela é apenas uma abstração carente do desenvolvimento expositivo dentro do qual ela adquiriria a possibilidade de sua compreensão ou, o que no caso do especulativo é o mesmo, mostrar-se-ia como o pensamento que a si mesmo pensa. Dito de outro modo, as proposições especulativas hegelianas não são outra coisa que um emaranhado propositivo, logicamente encadeado e que demonstra o desenvolvimento da totalidade em seu devir. Assim, elas comportam a oposição não apenas como modo de destruição da identidade inicial, mas como modo de recapturação e reafirmação posterior dessa mesma identidade, agora já em um grau outro, contendo em si sua própria negação e com ela, em algum grau, reconciliada. Faz tudo isso, frise-se, sem nunca suprimir a contradição, no entanto, apenas suprimindo a alteridade posta inicialmente.

O que isso aponta, antes de mais nada, é para uma modificação radical de posição frente à compreensão previamente exposta, aquela do entendimento. Se este acreditava, até seu último suspiro que a partir de seu uso do negativo poderia apenas nulificar certos conteúdos e se acreditava que o destino último era simplesmente pairar

\footnotetext{
372 Ibid, idem.

${ }^{373}$ HEGEL, 1992, p. 57.
} 
por sobre as coisas tendo seu Eu como repouso seguro era porque havia compreendido mal a negatividade. Agora terá que recompreender sua visada sobre o negativo, o que significa dar-se conta de que é justamente porque pensa a contradição como apenas uma intromissão de um Outro que pensa que o uso do negativo não pode ser produtivo. Pois a única coisa que resultava do uso do negativo, se nos lembrarmos, era a ausência do primeiro termo, sua destruição completa, sua negação abstrata, em suma. Agora, no entanto, a destruição cumprirá um papel de desenvolvimento, a morte fazendo com que algo surja de si, a destruição sendo a antessala da criação.

Importante pontuar que a palavra desenvolvimento (Entwicklung) nos fornece uma enganosa imagem bastante enraizada no que podemos chamar de realidade da finitude. Pensamos, assim, no desenvolvimento de uma criança, no desenvolvimento de competências, ou no desenvolvimento de estratégias. Em nenhum dos três cantos, pensamos no aspecto puramente lógico que, no entanto, é fundamental ao termo; antes, pensamos numa certa passagem do tempo e nas transformações ocorridas dentro desse espaço de tempo. Ou seja: o desenvolvimento se torna algo que transcorre, a bem dizer, num certo espaço e não seria errôneo dizer que, no tempo, a criança devém adulto, o não habilidoso devém hábil e a estratégia passa a existir e ser criada. Tudo isso no tempo. Pois bem: é justo isso que, em Hegel, desenvolvimento (e sua figura histórica, a formação), não é.

Como já vimos aqui, é justo uma crítica à fala sobre a contingência que Hegel elabora logo no primeiro capítulo de sua Fenomenologia. Uma tal fala conta com um certo conceito de tempo que é fundamentalmente centrado na divisão, proposta pelo entendimento, de um tempo presente como contraposto ao futuro e ao passado ou como termo médio entre eles. É, portanto, para além de uma crítica ao uso específico da linguagem, uma crítica também ao conceito de tempo que vai com esse uso da linguagem. Pois em um tal uso da linguagem a consciência não se dá conta de que é seu próprio modo de compreensão temporal que a direciona ao fracasso e à queda em impossibilidade de comunicar o que gostaria.

Um tal conceito de tempo se mostra igualmente presente nas últimas figuras que analisamos, o par consciência honrada/consciência dilacerada. Pois é o caso, para ambas, de se utilizarem de compreensões contrapostas, mas de fundo iguais, para tomar 
suas decisões e enunciar seus problemas: a primeira buscando algo fixo, dentro do reino da finitude, no qual se possa segurar; a segunda, manipulando completamente o negativo para demonstrar a finitude das coisas. Em ambos os casos, é a finitude que surge como pano de fundo a partir do qual se pode compreender a realidade e o mesmíssimo erro - ao menos aos olhos de Hegel - de um uso do lógico dentro das regras do efetivo ocorre. Dito de forma mais direta, a consciência honrada quer um valor que dure pra sempre, ao passo que a consciência dilacerada demonstra, a partir de seu cinismo e de sua nostalgia, a finitude dos valores. Nenhuma das duas deixa de girar em torno da tábua de valores finitos para julgar, mas ambas julgam como se pensassem numa eternidade, o que é a verdadeira imagem do presente para Hegel, se seguirmos Koyré ${ }^{374}$.

Quer isso dizer que toda a história da formação que Hegel conta, se é, de fato, uma narrativa totalizante, é por isso mesmo o momento do qual o tempo, enquanto reino absoluto da contingência por ser apenas devir ${ }^{375}$, está excluído. Se a história é recontada e se alguns eventos históricos são, de fato, recuperados, eles o são na medida em que tracejam um e o mesmo caminho, aquele mesmo caminho que é o do Espírito em sua liberação no mundo. Note-se: se toda a história não é outra coisa que não a história do Espírito Absoluto, é pressuposto que não exista nenhum Outro, salvo nos momentos específicos nos quais o Espírito não consegue se reconhecer ou, o que nesse contexto dá no mesmo, nos momentos em que está alienado. É, portanto, uma história sem Outro, sem um segundo personagem de peso igual que lhe possa opor uma resistência e o frear. Outra forma de dizer isso é dizer que o Espírito é seu próprio outrar-se, posto ser, em si mesmo, diferenciação de si e retomada de si a um só tempo. E isso casa perfeitamente bem com uma proposição especulativa, especialmente se pensarmos que "nela, o movimento dialético ao mesmo tempo toma pé. O pensar vêse por meio dela remetido a si mesmo".376

Se é assim e se o Espírito caminha com e pelos homens, se o caminha da história do Espírito se faz pela contingência, é preciso que Hegel mobilize uma imagem diferente daquela famosa linha reta que se dirige ao infinito que marcaria a

\footnotetext{
${ }^{374}$ KOYRÉ, 2011.

${ }^{375} \mathrm{Cf}$. o texto de Koyré, citado acima, sobre isso.

${ }^{376}$ GADAMER, 2012, p.116.
} 
compreensão hodierna de tempo. O que o tempo pensado como sucessão de instantes e perecimentos nos traz não é outra coisa do que o desfilar da alteridade enquanto tal, posto que dizer que as coisas perecem é dizer que elas encontram seu Outro absoluto, a saber, a morte. Não é por acaso que, no capítulo que desdobra ideias similares aos parágrafos que estamos analisando do Prefácio, i.e. aquele do Saber Absoluto, Hegel cunha a imagem necessária, afirmando o caminho da Fenomenologia é um movimento e "esse movimento é o círculo que retorna sobre si, que pressupõe seu começo e que só o atinge no fim." 377 O que está indicado aí é precisamente o caráter atemporal da lógica e, por conseguinte, da própria constituição lógica da realidade. O Espírito, por seu turno, porque marcha a partir dos desejos humanos, precisará chegar à totalização da consciência de seu desdobramento. Em suma, precisará de um momento histórico de volta a si, momento no qual a sua autocompreensão como que torce o rabo do tempo e o mostre que entre o fim e o começo se passa uma relação de identidade. Esse momento é a chegada à do Espírito à lógica ou a conclusão da formação, o que dá no mesmo. É a isso que Hegel está visando com essa mudança de imagem. Ademais, Hegel objetiva demonstrar que a formação efetuada pela leitura do livro não é outra coisa do que o reconhecimento, no/do plano lógico, da formação já efetuada no tempo. A passagem em revista da formação no efetivo visa efetivar a formação no campo lógico.

Especialmente na Fenomenologia, já que ali Hegel intenta ensinar a como fazer a passagem do tempo ao lógico, essa imagem demonstra também que toda a descrição histórico-temporal efetuada tinha apenas por objetivo desvelar a dialética da formação à consciência, fazendo-a compreender, ainda que sem tematizar diretamente, a estrutura lógica de sua formação. Se é esse o caso, nos lembrarmos de que a primeira metade da obra cuidou de formar a consciência como Espírito, nos ajuda a nos darmos conta do que, de fato, está em jogo em uma afirmativa como:

"No conceito que se sabe como conceito, os momentos se apresentam, pois, anteriormente ao todo implementado, cujo vir-aser é o movimento desses momentos. Na consciência, ao contrário, é anterior a esses momentos o todo, mas o todo não-conceituado. $\mathrm{O}$ tempo é o conceito mesmo, que é-aí, e que se faz presente à consciência como intuição vazia [pensemos em como o tempo é especializado e nunca pensado como contingencia, mas como espaço de ocorrência delas]. Por esse motivo, o espírito se manifesta

${ }^{377}$ HEGEL, 2000, p. 215. 
necessariamente no tempo; e manifesta-se no tempo enquanto não apreende seu conceito puro; quer dizer, enquanto não elimina o tempo." 378

Dizer "no conceito" bem poderia ser dito "na Ciência da Lógica..." sem grandes perdas de sentido, pois é precisamente isso que lá se encontrará: o automovimento do todo em seu desdobramento e reencontro com o puro ser que inicia a exposição. Ao comparar as duas posições, Hegel nos está dando, em algum grau, a justificativa de sua metodologia para a presente obra, e o motivo pelo qual decide começar pelo fim: se a consciência inicia a sua leitura sendo apresentada a um todo logo no começo do livro, no Prefácio ${ }^{379}$ e é só aos poucos que esse todo vai ser desdobrado até apreender-se conceitualmente, é porque esse é um movimento próprio da consciência não especulativa. Concordamos parcialmente com o que diz Bourgeois:

"Longe de ser a exposição historizante, embora muito livre, do desenvolvimento original do gênero humano, do espirito universal, A Fenomenologia do espírito propõe à consciência cultivada, mas ainda não hegeliana, uma rememoração racional desse desenvolvimento, que justifica a realização de seu último passo, a assunção do saber absoluto. Ora, essa rememoração racional mobiliza, a cada etapa dela mesma, e para poder prosseguir, a consciência normativa do verdadeiro como aquilo que contradiz a contradição reveladora do não-ser, ou seja, uma consciência já filosofante." 380

É necessidade da consciência, portanto, que exista um certo etapismo na maneira de progredir, posto que as experiências da consciência, especialmente aquelas de formação, só progredirem desde uma totalidade antecipada até o preenchimento momentâneo. Isso se faz assim porque a consciência ainda não foi educada para a lógica, o que significa que para educa-la é necessária a retirada gradual dos pressupostos que a fazem se apegar ao seu modo de filosofar que confunde contingência e passagem temporal e momentos conceituais.

${ }^{378}$ Ibid, idem, comentários em colchetes e negrito nossos.

${ }^{379}$ I.e., "O verdadeiro é o todo..."

${ }^{380}$ BOURGEOIS, 2004, p. 320, negrito nosso. A discordância parcial é porque "historizante" é tomado, em seu texto, como contrário a racional. Claro está que ele assume uma oposição a certas leituras que visaram buscar em Hegel uma história no sentido hodierno do termo. Como, no nosso caso, juntamos história e pensamento racional, poderíamos dizer que estamos de acordo com sua crítica em absoluto, mas preferiríamos tomar o cuidado de redefinir história nos termos hegelianos em detrimento de simplesmente abandonar o vocábulo. 
Eliminar o tempo, nesse sentido, cumpre a função de depurar de todo aspecto contingencial toda a formação efetuada até aqui (e a dupla referência de formação é proposital). Uma tal depuração se dá conta de que o Espírito é sim um movimento, mas "um mover-se que já não é mais medido por uma origem ou por um termo, que não começa assim como não termina, que não se acelera nem desacelera" ${ }^{381}$. Difere, portanto, da constante autonegação implícita na figura da reta ${ }^{382}$ e separa, de maneira fundamental, o Espírito dos homens que, no entanto, o movem e são (também) o Espírito. ${ }^{383}$ Não mais uma história de progressões em sentido temporal, não mais a história de sucessões de acontecimentos como uma grande narrativa da finitude dentro da qual um evento sucede o outro dentro do tempo, mas uma narrativa na qual o Espírito, qual músico monocórdio, constantemente se reencontra consigo mesmo nos mais diversos momentos que o entendimento compreende como diversos entre si da história.

Não que a diversidade não esteja presente, sejamos claros. Para Hegel, as viravoltas da história, se são apenas história do Espírito (no sentido de não serem outra coisa), são momentos fundamentais, uma vez que "a ciência não se manifesta no tempo e na efetividade antes que o espírito tenha chegado a essa consciência sobre si mesmo." 384 Vai daí, então, que apesar de existir uma lógica intrínseca ao processo de desdobramento do Espírito, ela só se torna compreensível no tempo. O tempo fornece ao Espírito as condições de sua própria reconciliação, sem ele a ciência não devém. Vê-se, aqui, a temática de uma necessidade a posteriori: antes do espírito ter consciência de si e produzir a ciência, tudo se passava como se fortuito fosse; uma vez que a ciência aparece, tudo é revisto à luz da logicidade que regeu o mundo até ali. Essa, a rememoração racional de que falou Bourgeois logo acima.

Sublinhe-se aqui que Hegel está se opondo avant la lettre a uma possibilidade de leitura de sua obra que basicamente a colocaria como um fundamento implícito, uma espécie de teodiceia na qual os homens estariam sendo guiados por uma providência

${ }^{381}$ LEBRUN, 1988, p.226.

382 Posto que para desenhar uma reta do tempo é preciso que eu passe deum agora a outro incessantemente. A reta se torna, assim, um abrigo ou coletânea de agoras mortos posto, como vimos, este se definir por ser apenas um negativo.

383 KOYRÉ, 2011.

${ }^{384}$ HEGEL, 2000, p.214. 
não divina, mas lógica ${ }^{385}$. Nada mais enganoso do que isso. Apesar do conceito engendrar a realidade, sendo essa uma afirmação categórica de Hegel na Lógica, é somente no fim que ele aparece, de modo que é descabido falar num jogo de prestidigitação ou numa série infinitas de pantomimas, espécie de "eles não sabem o que os rege, mas são regidos assim mesmo". Sendo explícito: o tempo é necessário ao Espírito porque sem ele não há possibilidade de ciência e, por conseguinte, de dialética. Note-se que é a consciência de si do Espírito no tempo que gera a ciência e não o contrário. Se é esse o caso, para que a contingência caia e o conceito tome seu lugar, $o$ tempo é peça fundamental.

Também é por isso que um livro com pretensões pedagógicas é forjado por Hegel. O que ocorre com o tempo, em relação ao conceito, não é pura oposição irreconciliável, mas supressão, ou seja, o conceito não se opõe ao tempo, o torna inócuo, "verga em círculo a sua reta" para usar outra vez a imagem de Lebrun. ${ }^{386}$ Isso explica porque o conceito de formação é tão central a Hegel: ele opera em ambos os polos, em ambos os registros, ao mesmo tempo. A formação é tanto passível de ser lida como o desdobramento lógico quanto como o desdobramento temporal do Espírito e da consciência em seu vir-a-ser consciente. Não só isso: sem um dos aspectos, o outro se torna inoperante de imediato. Se o Espírito se forma é preciso, de antemão, pressupor uma certa lógica que rege essa formação e um certo telos para ela; ao mesmo tempo, é preciso que ela transcorra de um modo tal que as contingências sejam necessariamente contadas como momentos importantes para um tal processo. A formação, então, fornece as condições fundamentais para que Hegel opere a passagem que está buscando aqui, pois esse conceito já é, em si mesmo, um termo médio cuja mobilização situa o leitor entre as linhas que Hegel busca caminhar. É nesse sentido, então, que podemos concordar com Gadamer quando este diz que a Fenomenologia tem a Lógica por base e esta última tem um grau Fenomenológico. É apenas já contanto com um certo entrelace específico das duas visadas que Hegel pode operar, ele mesmo, uma formação a partir do percurso pelo processo de formação.

\footnotetext{
385 Como Löwith dá a entender ao falar de uma providência divina.

386 LBERUN, 1988.
} 
Não é de estranhar então, que como na Fenomenologia, posteriormente as histórias hegelianas serão contadas de forma a haver sobreposições entre determinados períodos sem que, no entanto, isso prejudique em nada o caráter hierárquico que ele estabelece entre arte, religião e filosofia. Assim, é logicamente possível que a religião apareça duas vezes no mesmo livro e da segunda vez que apareça retorne sobre outra visada, sendo vista com um certo ganho de compreensão em relação a anteriormente, ainda que no terreno da realidade temporal - ou seja, tendo em vista a sucessão de eventos ocorridos - ela tenha pouco ou nada se modificado. Dito de outro modo, é plenamente possível a Hegel construir hierarquias lógicas de verdade mesmo que as coisas se passem de outra forma no terreno contingencial porque não o interessa a pertinência exclusivamente temporal de uma era, interessa sobretudo a maneira pela qual o Espírito se desdobra. Isso porque uma tal exposição do seu desdobramento terá uma estrutura lógica, similar àquela da demonstração especulativa. Assim:

Pode-se lembrar a respeito que o movimento dialético tem igualmente proposições como partes ou elementos seus: a dificuldade indicada parece assim voltar sempre, e ser uma dificuldade da Coisa mesma. É semelhante ao que sucede na demonstração ordinária: os fundamentos que utiliza precisam por sua vez de uma fundamentação, e assim por diante até o infinito. Mas essa forma de fundar e de condicionar pertence àquele demonstrar que é diferente do movimento dialético; portanto, pertence ao conhecer exterior. No que toca ao movimento dialético, seu elemento é o conceito puro, e por isso tem um conteúdo que em si mesmo é absolutamente sujeito. Assim, nenhum conteúdo ocorre que se comporte ao modo de um sujeito posto como fundamento, e ao qual advenha sua significação como um predicado: a proposição, imediatamente, é só uma forma vazia ${ }^{387}$

A importância que Hegel confere à exposição daquilo que é dialético se torna bastante clara aqui. A exposição não é apenas uma maneira de fazer com que aquele para quem está sendo exposto o assunto compreenda de maneira clara e irretocável aquilo de que se fala; para além disso, a exposição especulativa é o próprio assunto se mostrando em sua verdade. Vai daí então que Hegel entenda que seu método expõe o conteúdo porque expõe seu processo inteiro de tornar-se evidente e real ou, o que dá no mesmo, a exposição é o que torna o previamente contingente conceito e, portanto, o apreende em sua lógica. No caso específico do Espírito, por ser esse um conteúdo

${ }^{387}$ HEGEL, 1992, p.58. 
que depende de seu próprio desdobrar contingente para que se possa saber sua forma lógica, a maneira precisa de descobrir sua estrutura lógica é uma rememoração que já assuma uma certa lógica como fio condutor, mas a exponha de maneira puramente fenomenológica. É uma forma de fazer com que o Espírito se reconheça sujeito e, nesse sentido, se reconheça como e no movimento da verdade:

A proposição deve exprimir o que é o verdadeiro; mas essencialmente, o verdadeiro é o sujeito: e como tal é somente o movimento dialético, esse caminhar que a si mesmo produz, que avança e que retorna a si. Em qualquer outro conhecer, a demonstração constitui esse lado da expressão da interioridade. Porém, desde que a dialética foi separada da demonstração, o conceito da demonstração filosófica de fato se perdeu. ${ }^{388}$

Podemos sublinhar, agora, o peso que tem, dentro da exposição dialética, o fato de Hegel dedicar longas horas criticando certos eventos de época como a existência de um prefácio ou a filosofia kantiana: em todos esses casos, uma certa lógica da exposição está sendo mobilizada para que os conteúdos ganhem seu perfeito desdobramento lógico. Por isso que, ao expormos nossa leitura da crítica de Hegel aos prefácios, fizemos tanta questão de situá-la como uma negação determinada, não como uma crítica simples ou um posicionamento contrário segundo o qual Hegel estaria dizendo "mas eu não faço isso": uma vez situada como parte da exposição, a crítica não pode mais servir para algo exterior a ela, tem que ter necessariamente algum tipo de ligação real com a maneira pela qual Hegel quer expor o Todo. Por mais que existam referências às coisas externas, elas têm de servir ao próprio automovimento do conceito, sob pena de serem redutíveis a apenas observações vãs. É o próprio Hegel que o afirma: "a apresentação, fiel à visão da natureza do especulativo, deve manter a forma dialética e nada incluir a não ser na medida que é concebido e que é o conceito." 389

Note-se então a necessidade como ordenador central da exposição do especulativo, nada dela conseguindo escapar pois caso o fizesse já se estaria no terreno do contingencial. É importante frisarmos isso para que, de maneira nenhuma, caiamos na confusão de uma retomada do contingente por Hegel. Apesar da ênfase conferida ao

\footnotetext{
${ }^{388}$ Ibid, idem.

${ }^{389}$ Ibid, idem.
} 
negativo enquanto operador lógico, é sumamente em direção à reconciliação que este caminha. No frigir dos ovos, é à destruição de uma oposição estrita que Hegel caminha, porque uma tal oposição é ela mesma oriunda de um erro. É precisamente esse o sentido da leitura de Zizek ao dizer que do que didaticamente se chama antítese ao que se chama, no mesmo registro, síntese, só há um processo de reconhecimento da legitimidade da antítese ou, de outra forma, só há a descoberta de que a contradição só aparece como falha para um entendimento que abstrai e opõe $\mathrm{e}^{390}$. Expor o especulativo desde o entendimento é sempre um erro porque:

se forem enunciadas verdades especulativas sobre aquele sujeito, seu conteúdo carece de conceito imanente, pois o sujeito só está presente como sujeito em repouso, e por essa circunstância tais verdades recebem facilmente a forma de mera edificação. Sob esse aspecto também o obstáculo reside no hábito de entender, segundo a forma da proposição, o predicado especulativo, e não como conceito ou essência; e pode aumentar ou diminuir por culpa da própria exposição filosófica. ${ }^{391}$

Vê-se, então, quão radical é a separação que Hegel faz intervir entre o entendimento e a razão especulativa.

Apesar da dedicação com que Hegel critica as filosofias do entendimento, como seu centro focal é a noção de formação, supõe-se que essas filosofias não serão as únicas oposições ao pensar dialético que ele identificará. Pois um autor que busca formar não tem apenas contra si o fato de que outras formações existem, mas também que uma certa posição de retificação de verdades postas se mantenha, uma espécie de escolha decida pela manutenção dos preconceitos. E bem sabida a exaltação que Descartes faz do bom senso como o que há de mais bem distribuído entre os homens e é exatamente contra esse bom senso bem distribuído que Hegel - após ter desferido seus golpes contra as filosofias de seu tempo - vai se voltar.

No que concerne à filosofia autêntica - esse longo caminho da cultura (Bildung [podendo ser também: da formação]), esse movimento tão rico quanto profundo através do qual o espírito alcança o saber -, vemos que são considerados equivalentes perfeitos e ótimos sucedâneos seus a revelação imediata do divino ou o bom senso

${ }^{390}$ ZIZEK, 2014, p.49-50.

${ }^{391}$ HEGEL, 1992, p.58. 
comum. É algo assim como se faz publicidade da chicória como bom sucedâneo do café. ${ }^{392}$

Ressaltar que a filosofia é um longo caminho da cultura tem aqui uma dupla função: a primeira é marcar uma posição de trabalho e paciência inerentes ao próprio desdobramento do Espírito, uma vez que a filosofia só ocorre no tempo em que o Espírito se encontra preparado para produzi-la; a segunda é estabelecer de maneira clara a impossibilidade de se filosofar a partir da "presunção das verdades feitas" 393 . São acenos, a partir de dois eixos para a mesma coisa, a saber, aquilo que até aqui chamamos de formação. Não se pode falar numa formação filosófica sem se presumir a necessidade de um certo tempo que equivale a essa exata formação, a sucessão de eventos necessários para ela sendo precisamente a maneira pela qual compreendemos o tempo; de maneira idêntica, também não se pode falar em formação sem se pensar que é exigido um certo labor, um certo desprendimento de si e algum grau de aniquilação de si mesmo. A esse último aspecto, Hegel conferirá a maior importância e o nomeará experiência (Erfahrung).

Não é outra coisa que vemos no capítulo sobre o Saber Absoluto. Após ter apresentado os ganhos de todo o percurso do Espírito até o presente momento e apresentar o caminhar da consciência em direção à sua reconciliação, desfazendo a cisão consciência/consciência-de-si, Hegel fará questão de sublinhar que todo o percurso, a supressão do tempo inerente à chegada ao conceito e a reconciliação só são possível em razão da experiência, porque

Por essa razão deve-se dizer que nada é sabido que não esteja na experiência (was nicht in der Erfahrung ist oder); - ou, como também se exprime a mesma coisa - que não esteja presente como verdade sentida, como Eterno interiormente revelado, como o sagrado em que se crê, ou quaisquer outras expressões que sejam empregadas. Com efeito, a experiência é exatamente isto: que o conteúdo - e ele é o espírito - seja em si substância, e assim, objeto da consciência. Mas essa substância, que é o espírito, é o seu vir-a-ser para [ser] o que é em si; e só como esse vir-a-ser refletindo-se sobre si mesmo ele é em si, em verdade, o espírito. O espírito é em si o movimento que é o

${ }^{392}$ HEGEL, 1992, p.59, colchetes nossos. Curiosidade mórbida: de fato, ainda hoje se pensa a chicória como substituto do café. Quaisquer rápidas pesquisas no buscador de preferência retornam um sem número de pesquisas e produtos nessa direção.

${ }^{393}$ HEGEL, 1992, pp.58-59. 
conhecer, - a transformação desse Em-si no Para-si; da substância no sujeito; do objeto da consciência em objeto da consciência-de-si; isto é, em objeto igualmente suprassumido, ou seja, no conceito. Esse movimento é o círculo que retorna sobre si, que pressupõe seu começo e que só o atinge no fim. ${ }^{394}$

Se o processo formativo deve ser analisado, ele é feito de modo que todas as experiências do Espírito sejam vividas pela consciência como experiências suas, posto que é justo a experiência que permite que o em si, outrora completamente estranhado, se transforme em para si, realidade humana compreensível e cujo interior se torna já, ele mesmo, amarrado à consciência de si. De maneira similar, é também a experiência que faz com que a cisão visível entre objeto de conhecimento e sujeito conhecedor seja dissolvida e transformada na identidade de um com o outro ainda mantendo a diferença. Nas palavras de Hyppolite, "experiência é a transformação do em si no para si; ela expressa a necessidade de tornar real e revelar o que é, inicialmente, apenas interior" 395 .

Junto com a formação, vemos com a experiência o outro termo que opera passagem da realidade efetiva e contingencial para a realidade lógica. Toda experiência do Espírito foi necessariamente temporal e foi, por isso, uma história - ainda que não se saiba assim quando ocorre. Se é assim, a análise de todo o processo contingencial e as totalizações desse processo, quando experimentados pela consciência, possuem um estatuto similar àquelas próprias experiências que foram o desdobrar do Espírito, uma vez que as experiências de leitura também são experiências em suas próprias configurações mais básicas. São, também elas, momentos diferenciais nos quais a consciência leitora gradualmente se apropria. Se mantém um grau de diferença necessário à possibilidade mesma de diferenciação, já não enxerga mais como uma oposição absoluta sobre a qual nada sabe e da qual se vê completamente alienada. Se vendo formada consegue, então, nomear aquela experiência como sua e estabelecer, também ela, a identidade entre a identidade (o fato de ser si mesma) e diferença (o livro que tem em sua frente). Uma vez concluído o processo de percurso racional pela história da formação que é, em si mesmo, formativo, a consciência se vê em condições

\footnotetext{
${ }^{394}$ HEGEL, 2000, p. 215.

${ }^{395}$ HYPPOLITE, 1979, p.578.
} 
de iniciar a leitura da Lógica e de apreender a totalidade lógica não a partir de sua pressuposição, mas de seu desdobramento momento a momento. E por que a experiência é necessária como caminho à formação? Deixemos que o autor nos responda:

Experiência é justamente o nome desse movimento em que o imediato, o não-experimentado, ou seja, o abstrato - quer do ser sensível, quer do Simples apenas pensado - se aliena e depois retorna a si dessa alienação; e por isso - como é também propriedade da consciência - somente então é exposto em sua efetividade e verdade. ${ }^{396}$

Ora, se a consciência só consegue apreender a totalidade como pressuposta, mas não conceituada, ela a apreende como antecipação daquilo que ainda não se externalizou, ou seja, ela antecipa sua própria visão de totalidade antes que esta última se mostre no tempo. Todo o processo de se externalizar é, então, uma espécie de conferência de existência àquilo que inicialmente é apenas pressuposto, o que leva Hyppolite a afirmar que o itinerário fenomenológico é o Espírito fazendo uma peça, no sentido teatral sobre si mesmo e, por fim, se reconhecendo nessa peça ${ }^{397}$. Sendo assim, a experiência será a possibilidade da consciência saber que é ela enquanto Espírito que deve se apropriar da experiência que ela já é, mas ainda não reconhece; deve ser capaz, portanto, de reconhecer seu próprio processo formativo e, nesse processo, formar-se para a ciência. É somente percorrendo todos os estágios da formação e, ao fim, suprimindo o tempo porque chega ao conceito que a consciência consegue recapturar a totalidade pressuposta das experiências do Espírito no grau do conceito e pode, com isso, iniciar seu percurso na lógica especulativa.

A temática da reconciliação chega, assim, à sua culminância e podemos ver com clareza que reconciliar não é, de maneira nenhuma, abolir as oposições, mas recaptura-la em sua natureza de desenvolvimento lógico:

A desigualdade que se estabelece na consciência entre o $\mathrm{Eu}$ e a substância - que é seu objeto - é a diferença entre eles, o negativo em geral. Pode considerar-se como falha dos dois, mas é sua alma, ou seja, é o que os move. Foi por isso que alguns dos antigos conceberam o vazio como o motor. De fato, o que conceberam foi o motor como o negativo, mas ainda não o negativo como o Si. Ora,

\footnotetext{
${ }^{396}$ HEGEL, 1992, p.40.

${ }^{397}$ HYPPOLITE, 1974, p.579.
} 
se esse negativo aparece primeiro como desigualdade do Eu em relação ao objeto, é do mesmo modo desigualdade da substância consigo mesma. $O$ que parece ocorrer fora dela - ser uma atividade dirigida contra ela - é o seu próprio agir; e ela se mostra ser essencialmente sujeito. ${ }^{398}$

Como esse parágrafo versa sobre o espírito objetivado e sua relação com a experiência, depreendemos que não é, portanto, apenas o eu que analisa que é desigual com ao espírito tornado substância; é a própria substância espiritual que é, também, desigual consigo mesma. A diferenciação que inicialmente se mostrou como sendo o motor que levava o indivíduo ao erro por proferir universais tentando capturar singulares (foi nosso segundo capítulo) se mostra agora como algo que, independentemente dele, já é diferente de si mesma porque é sujeito. Uma outra forma de dizer isso é afirmar que a consciência tem por princípio a diferenciação que faz entre si mesma e o espírito e, eventualmente, percebe que o que ocorre é que ela mesma é o Espírito se diferenciando de si, posto que ela só existe na contraluz das experiências deste, só se forma desde um Espírito em cuja história ela está imersa. Nesse último momento, no qual a consciência recaptura sua própria natureza espiritual e compreende que é, ela mesma, também a objetivação que fazia e percebe que seu eu é não só sujeito, mas também substância, é o momento no qual cessa a separação entre ser e saber e inicia a verdadeira compreensão da oposição entre eles ${ }^{399}$. Todo o itinerário fenomenológico cessa, posto que o negativo já foi integrado como figura central ao desenvolvimento e a oposição deixou de ser vista como separação e impossibilidade identitária. Agora é vista como a real possibilidade de seu desenvolvimento. A consciência está pronta, assim, para iniciar seu caminho na Lógica.

${ }^{398}$ HEGEL, 1992, p.40, negrito nosso, itálicos do autor.

399 "Esses momentos já não incidem na oposição entre o ser e o saber, separadamente; mas ficam na simplicidade do saber - são o verdadeiro na forma do verdadeiro, e sua diversidade é só diversidade de conteúdo. Seu movimento, que nesse elemento se organiza em um todo, é a Lógica ou Filosofia Especulativa" HEGEL, 1992, p.41, negrito nosso. 


\section{5}

\section{Conclusão: Concluir sem terminar}

Se fomos bem sucedidos em nosso intento, conseguimos abrir uma possibilidade outra de compreensão do que significa iniciar pelo fim. Significa, sobretudo, a possibilidade de abolir de maneira definitiva o que se chama de começo e de fim, especialmente porque essas noções costumam vir uma a reboque da outra. Essa estrutura, quando adotada por Hegel, nos pareceu deslocar o problema da formação de seu eixo, que costuma colocar questões sobre seu início e sobre seu fim, ou seja, costuma nos colocar a questão e quando podemos nos saber formados filosoficamente e do quanto é suficiente para isso.

Ao iniciar a formação do fim, termina-la no começo ou ainda, pressupô-la pronta para que ela assim possa começar, Hegel nos dá a possibilidade de repensar a questão desde o ponto de vista de uma continuidade formativa que já se deu, vez que toda a roda só pode girar se já estiver girando. Isso quer dizer que, paradoxalmente, não existe uma formação sem que ela já tenha, em algum grau, começado e terminado ao mesmo tempo, ainda que, obviamente, isso não se dê na concretude material e contingente, mas no plano lógico.

Uma tal postura nos parece coadunar com a atualização de Hegel que buscamos fazer, não tanto para torna-lo um autor pós-moderno ou contemporâneo avant la lettre, mas para situá-lo de um modo outro na história da filosofia, um modo que não assume a existência de uma história filosófica pronta para que descobríssemos, mas que nos responsabiliza pela história que construímos e faz dessa história filosófica que fazemos a história de nossa formação. Ao fim e ao cabo, o próprio Hegel nos autoriza uma tal interpretação de sua obra, vez que era também ele preocupado com os desafios e questões de seu presente e fez deles o leitmotiv de seu trabalho, ainda que tenha escolhido um olhar em retrospecto para fazê-lo.

Isso tudo significa, então, que ao tentar ler o Prefácio de Hegel de modo a extrair dele consequências, repetimos diferencialmente, conforme dissemos, o gesto de 
Marcos Nobre ao se debruçar sobre a introdução do mesmo livro por nós analisado ${ }^{400}$. Proporções guardadas e vetores diversos respeitados (ele pensa sob o signo do novo e nós sob o do passado, afinal), fazemo-lo, parece, por uma repetição do gesto do próprio autor que é o nosso. Esses esforços se inserem na possibilidade que Hegel nos abre, especialmente na Fenomenologia, de pensar questões outras, relativas aos problemas do presente. Especialmente ali porque ela um livro estranho mesmo para seu autor que, por vezes, o definia como sua própria jornada de descoberta filosófica. Um tal livro insituável (ou monstruoso, para usar uma expressão mais contemporânea) é um feixe de questões múltiplas que espera que observadores se posicionem em ângulo adequados para vê-las.

Especificamente em nossa tese, tratar a questão da formação de maneira enfática na filosofia hegeliana e pensa-la a partir do Prefácio nos pareceu ser um aceno na direção contrária a um fazer filosófico atual que constantemente busca pensar o presente enquanto ele acontece, vaticinando e prevendo e não tanto analisando e compreendendo suas condições de formação. Apostamos nessa hipótese em nossa tese porque cremos que um olhar em retrospecto, como buscamos delinear aqui, nos abre possibilidades outras de pensar o presente que não sejam absolutamente marcadas pelo frenesi do contemporâneo ou pela ausência angustiante de previsões possíveis, boas ou más, sobre o futuro.

Acreditamos que, ao deslocar todo questionamento sobre o presente para uma reflexão sobre a formação deste mesmo presente, ganhamos espaço para pensar que a resposta aos porquês do presente nunca deve ser buscada de maneira a pensar no futuro ou no próprio presente como solução, uma vez que esses, grosso modo, não dão conta de circunscrever a origem da situação vivida nem seus nexos de necessidade.

Não nos parecia existir texto mais próprio para a nossa questão do que esse Prefácio dessa obra, uma vez que, como vimos, ele entrelaça sua compreensão completa à compreensão da obra como um todo, sendo então um texto cuja leitura só se torna plena se seus pressupostos de abolição de fim e começo forem realizados. É

${ }^{400}$ NOBRE, 2018. Digno de nota que Marcos nobre pareça ter algumas posturas metafilosóficas bastante próximas da nossa o que, para nós, foi e continua sendo uma alegria. 
um texto que literalmente forma e exige a formação para ser lido a um só tempo. Uma tal estrutura coaduna com um poema de Elliot, segundo o qual:

E criar um fim é criar um começo.

O fim é a partir de onde começamos. E toda frase

E enunciação correcta (onde cada palavra esteja bem acomodada,

Ocupando o seu lugar para suportar as outras,

A palavra nem tímida nem ostentatória,

Uma fácil negociação entre o antigo e o novo,

A palavra comum exacta sem vulgaridade,

A palavra formal precisa, mas não pedante,

O consórcio pleno dançando juntas)

Cada frase e cada enunciação é um fim e um começo. ${ }^{401}$

Se cada enunciação de e cada frase é um fim e um começo, a um só tempo, cada filosofia, dada que é demonstrada racionalmente pela linguagem, precisa dar conta dessa questão a seu modo. No caso de Hegel (e no nosso), foi questão de assumir que a dicotomia fim/começo, em relação a formação, apenas existe na medida em que uma abstração está em jogo, posto que não existe nenhuma exterioridade salvo aquela que é por nós positivada. Formar-se se torna, em decorrência disso, tornar-se capaz de reconhecer aquilo com o que se conta para que se possa pensar em um processo de formação. É, portanto, um processo circular, finito e infinito. Esta, uma outra forma de dizer que, com Hegel, vemos que o fim é uma categoria lógica que pressupõe a auto compreensão de todo o processo e, portanto, seu recomeço já está, em algum grau, contado, posto ser uma formação compreensiva dos processos que não se tornarão diferentes, mas os mesmos de sempre, apenas esclarecidos. Formar-se, com Hegel é, assim, um eterno recomeçar. .

${ }^{401}$ ELLIOT, 2009, p.87. 


\section{6}

\section{Referências bibliográficas}

\section{Obras de Hegel:}

HEGEL, G. W. F. Fenomenologia do Espírito, I. Trad. br. Paulo Meneses. Petrópolis: Vozes, 1992.

Cursos de Estética. Vol. II. Tradução de M. A. Werle. São

Paulo: Edusp, 2014.

Ciência da lógica 1: A doutrina do ser. Trad. Br. Christian

Iber, Marloren Miranda e Frederico Orsini. Petrópolis: Vozes, 2016.

Ciência da lógica 2: A doutrina da essência. Trad. Br.

Christian Iber e Frederico Orsini. Petrópolis: Vozes, 2017.

Enciclopédia das ciências filosóficas, vol III: A filosofia

do Espírito. Trad. Paulo Meneses e Pe. José Machado. São Paulo: Loyola, 2017. Filosofia da História. Trad. Maria Rodrigues e Hans

Harden. Brasília: Editora da UNB, 2008. Grundlinien der Philosophie des Rechts, Frankfurt:

Suhrkamp, 1986.

Linhas Fundamentais da Filosofia do Direito ou Direito

Natural e Ciência do Estado em Compêndio. Trad. Paulo Meneses et. all. São Leopoldo, Ed. UNISINOS: 2010.

Propedêutica Filosófica. Tradução Artur Mourão. Lisboa:

Edições 70, 2018.

Fenomenologia do Espírito, II. Trad. br. Paulo Meneses.

Petrópolis: Vozes, 2000. 
Werke 10, Frankfurt am Main: Suhrkamp (Taschenbuch Wissenschaft), 1995. Vorlesungen über die Philosophie der Geschichte,

Frankfurt: Suhrkamp, 1986.

. Phänomenologie des Geistes. Werke 3. Frankfurt:

Suhrkamp, 1986. . Philosophische Propädeutik. In HEGEL, G. Hegel

Studienausgabe - Band 3. Frankfurt: Fischer, 1989.

Wissenschaft der Logik I. Frankfurt: Suhrkamp, 1986.

\section{Obras sobre Hegel e dialética hegeliana}

ADORNO, T. Reflexões sobre a teoria de classes. Crítica Marxista, n.50, p.259-273, 2020. Disponível em: https://www.ifch.unicamp.br/criticamarxista/arquivos_biblioteca/documento202 1_03_19_17_02_26.pdf Acessado em: 20/09/2021. . Três estudos sobre Hegel. São Paulo: Editora Unesp, 2007.

AGAMBEN, G. A linguagem e a morte: um seminário sobre o lugar da negatividade. Tradução Henrique Burigo. Belo Horizonte: Editora da UFMG, 2006.

ARANTES, P. Ressentimento da dialética: dialética e experiência intelectual em Hegel. Rio de Janeiro: Paz e Terra, 1996.

. Hegel - A Ordem do tempo. São Paulo: Polis, 1981. Hegel, Frente e Verso. Discurso, (22), 153-166.

BOURGEOIS, B. Hegel: os atos do espírito. Trad. Paulo Neves. São Leopoldo: Editora UNISINOS, 2004. 
BUCK-MORSS, S. Hegel, Haiti, and universal history. pITTSBURG: University of Pittsburgh Press, 2009

BUTLER, J. Subjects of Desire: hegelian reflections in twentieth-century France. New York: Columbia University Press, 2012.

COSSETIN, V. L. F. A dissonância no absoluto: linguagem e conceito em Hegel. Ijuí: Ed. Unijuí, 2012.

FEUERBACH, L. Para a crítica da filosofia de Hegel. Trad. Adriana Veríssimo Serrão. Edição Bilingue. São Paulo: LiberArs, 2012.

FILHO, R. A sombra do iluminismo. In: FILHO, R. Ensaios de filosofia ilustrada. São Paulo: Iluminuras, 2004.

FORSTER, M. Hegel's idea of a Phenomenology of Spirit. Chicago: The University of Chicago Press, 1998.

- Hegel's dialectical method. In: BEISER, F. Cambridge Companion to Hegel. Cambridge: CUP, 1999.

GADAMER, H-G. Hegel, Husserl, Heidegger. Trad. Marco Casanova. Petrópolis: Vozes, 2012.

HABERMAS, J. O discurso filosófico da modernidade. São Paulo: Martins Fontes, 2000.

HENRICH, D. Hegel en su contexto. Traducción Jorge Aurelio Diaz. Caracas: Monte Avila Editores, 1990.

Between Kant and Hegel. Ed. D. S. Pacini. Cambridge, MA: Harvard University Press, 2008.

.Hegel im Kontext. Frankfurt am Main: Suhrkamp Verlag, 1971.

HYPPOLITE, J. Genesis and structure of Hegel's Phenomenology of Spirit. Transl. Samuel Cherniak and John Heckman. Illinois: NUP, 1974.

. Genèse et Structure de la Phénomenologie de l'Esprit, vol.I e II, Paris: Aubier, Éditions Mantaigne, 1967. 
Logique et Existence. Paris: PUF, 2012

Gênese e estrutura da Fenomenologia do Espírito de Hegel.

São Paulo: Discurso, 1999.

KOJÈVE, A. Introduction à la Lecture de Hegel. Paris: Gallimard, 1947.

. Introdução à leitura de Hegel. Rio de Janeiro: Contraponto, 2002.

KOYRÉ, A. História do pensamento filosófico. Rio de Janeiro: Forense, 2011.

KUSSUMI, M. Antinomia ideal: Estudo comparativo entre Schelling e Hegel. 2020. Tese (doutorado) - PPGFIL, PUC-RIO, Rio de Janeiro, 2020.

LEBRUN, G. O avesso da dialética: Hegel à luz de Nietzsche. Trad. Renato Janine Ribeiro. São Paulo: Companhia das Letras, 1988.

A Paciência do conceito: ensaio sobre o discurso hegeliano. Trad. Silvio Rosa Filho. São Paulo: Editora da UNESP, 2006.

La Patience du concept: essai sur le Discours hégélien. Paris:

Gallimard, 1972.

LONGUENESSE, B. Hegel's critique of metaphysics. Cambridge: CUP, 2007.

LOSURDO, D. Hegel e a liberdade dos modernos. Tradução de Ana Maria Chiriani e Diego Silveira Ferreira. São Paulo: Boitempo, 2019.

LÖWITH, K. De Hegel a Nietzsche: a rupture revolucionária no pensamento do século XIX: Marx e Kierkegaard. Tradução de Flamarion Caldeira Ramos e Luiz Martin. São Paulo: Editora da UNESP, 2014.

. Meaning in History. Chicago and London: UCP, 1949.

LUKÁCS, G. O jovem Hegel e os problemas da sociedade capitalista. São Paulo: Boitempo, 2018.

MACHEREY, P \& LEFEBVRE, J-P. Hegel e a sociedade. São Paulo: Discurso editorial, 1999. 
MALABOU, C. L'avenir de Hegel: plasticité, temporalité, dialectique. Paris: Vrin, 1996.

MARCUSE, H. Razão e Revolução: Hegel e o advento da teoria social. Rio de Janeiro, Paz e Terra: 1988.

MASTRO, F. A representação e a emergência do conceito na Ciência da lógica. 2021. Dissertação (mestrado) - PPGFIL, USP, São Paulo, 2021.

MIRANDA, M. O voo da coruja entre a luz e a sombra: acerca do saber absoluto e da possibilidade de uma nova figura do espírito. 2018. Tese (doutorado) PPGF, UFRGS, Rio Grande do Sul, 2018.

- A escrita filosófica hegeliana: acerca da noção de narrativa especulativa. In: BAVARESCO, Agemir; PERTILlE, José Pinheiro; MIRANDA, Marloren Lopes; TAUCHEN, Jair (Orgs.). Leituras da Lógica de Hegel. Porto Alegre: Editora Fi, 2017.

MÜLLER, R. A crítica de Hegel ao formalismo moral kantiano. 2011. Tese (doutorado) - Pós Graduação em Filosofia, PUCRS, Rio Grande do Sul, 2011.

NOBRE, M. Como nasce o novo: Experiência e diagnóstico de tempo na Fenomenologia do espírito de Hegel. São Paulo: Todavia, 2018.

NOLASCO, F. A suspensão qualitativa da quantidade: a crítica de Hegel ao paradigma matemático da ciência moderna. 2015. Tese (doutorado) - PPGFIL, UNICAMP, Campinas, 2015.

PINKARD, T. Hegel: a biography. Cambridge: CUP, 2007.

Hegel's phenomenology: the sociality of reason. Cambridge:

Cambridge University Press, 1996.

PIPPIN, R. Hegel's Idealism: The Satisfactions of Self-Consciousness. Cambridge: CUP, 1989.

SAFATLE, V. O circuito dos afetos: corpos políticos, desamparo e o fim do indivíduo. São Paulo: Cosac Naify, 2015.

Muito longe, muito perto: dialética, ironia e cinismo a partir da leitura hegeliana de O sobrinho de Rameau. Artefilosofia, v.2. n.2, 2007, p. 36-55. 
. Linguagem e negação: sobre as relaçõesentre pragmática e ontologia em Hegel. Revista Dois pontos. Curitiba - São Carlos, v.3, n.1, 2016.

SUZUKI, M. Sobre Música e Ironia. Idealismo Alemão. Revista Dois Pontos. Curitiba - São Carlos, v. 4, n. 1, p. 175-200, 2007.

XIAOMANG, D. Heidegger's distortion of dialectics in "Hegel's

Concept of Experience" Front. Philos. China 2009, 4(2): 294-307.

ZIZEK, S. The Most Sublime Hysteric: Hegel with Lacan. Cambridge: Polity Press, 2014.

. Hegel in a wired brain. London: Bloomsbury Academic, 2020.

.Less than nothing: Hegel and the shadow of dialectical materialism.

London: Verso, 2012.

Obras de/sobre outros autores citados na tese

BEISER, F. German idealism: the struggle against subjectivism, 1781 -1801. Cambridge: HUP, 2012.

COUTINHO JORGE, M. Fundamentos da psicanálise de Freud a Lacan: a prática analítica. Rio de Janeiro: Jorge Zahar Editora, 2017.

DELEUZE, G. Différence et répétition. Paris: PUF, 1968.

DERRIDA, J. De la grammatologie. Paris: Les Éditions de Minuit, 1967.

DIDEROT, D. O sobrinho de Rameau. Ttradução de J. Guinsburg São Paulo: Perspectiva, 2006.

ANDRADE, P. Estio do tempo: romantismo e estética moderna. Rio de Janeiro: Jorge Zahar Editora, 2011.

FOUCAULT, M. A Ordem do Discurso. aula inaugural no Collège de France, pronunciada em 2 de dezembro de 1970. São Paulo: Loyola, 1999. 
FREUD, S. Luto e melancolia. In: FREUD, S. Edição Standard das obras psicológicas completas de Sigmund Freud, vol XIV. Rio de Janeiro: Imago, 2006.

FUKUYAMA, F. The end of history and the last man. New York: Free Press, 1992.

HÖLDERLIN, F. Urteil und Sein. Disponível em: https://www.textlog.de/urteilsein.html. Acesso em: 20 de agosto de 2021.

KANT, I. Crítica da Razão Pura. Lisboa, Fundação Calouste Gulbekian, 2010.

. O que é o esclarecimento? In: KANT, I. Textos seletos. Petrópolis: Vozes, 1985.

KIERKEGAARD, S. O conceito de ironia constantemente referido a Sócrates. Petrópolis: Vozes, 1991.

LEBRUN, G. Kant e o fim da metafísica. Trad. Carlos Alberto Ribeiro de Moura. São Paulo: Martins Fontes, 2002.

NANCY, J-L. The literary absolute. New York: State University of New York Press, 1988.

PAZ, O. Os filhos do barro: do Romantismo à vanguarda. Trad. Olga Savary. Rio de Janeiro: Nova Fronteira, 1984.

QUEVEDO, W. Hölderlin em Iena: união e cisão nos limites do pensamento. 2018. Tese (doutorado). PPGFIL, UFMG, Belo Horizonte, 2018.

SCHLEGEL, F. O dialeto dos fragmentos. Tradução de Márcio Suzuki. São Paulo: Iluminuras, 1997.

SHAKESPEARE, W. Romeo and Juliet. Cambridge: CUP, 2003. 